UNIVERSIDADE DE SÃO PAULO

FACULDADE DE FILOSOFIA LETRAS E CIÊNCIAS HUMANAS DEPARTAMENTO DE TEORIA LETRAS CLÁSSICAS E VERNÁCULAS PROGRAMA DE PÓS-GRADUAÇÃO EM ESTUDOS COMPARADOS DE LITERATURAS DE LÍNGUA PORTUGUESA

JANE PINHEIRO DE FREITAS

VISÕES DO (DES)ENCANTO: UM ESTUDO SOBRE O FEMININO TRANSGRESSOR EM CLARICE LISPECTOR E MARIA JUDITE DE CARVALHO

SÃO PAULO

2011 
UNIVERSIDADE DE SÃO PAULO

FACULDADE DE FILOSOFIA LETRAS E CIÊNCIAS HUMANAS

DEPARTAMENTO DE TEORIA LETRAS CLÁSSICAS E VERNÁCULAS

PROGRAMA DE PÓS-GRADUAÇÃO EM ESTUDOS COMPARADOS DE

LITERATURAS DE LÍNGUA PORTUGUESA

\section{Visões do (des)encanto: um estudo sobre o feminino transgressor em Clarice Lispector e Maria Judite de Carvalho}

Jane Pinheiro de Freitas

Tese apresentada à Faculdade de Filosofia, Letras e Ciências Humanas da Universidade de São Paulo USP, para obtenção do título de Doutor(a) em Letras, na área de Estudos Comparados de Literaturas de Língua Portuguesa.

Orientadoras: Prof. Dra. Maria dos Prazeres Mendes (USP)

Prof. Dra. Maria Graciete Besse (Sorbonne-PARIS IV)

São Paulo

2011 


\section{RESUMO}

A pesquisa de Doutorado intitulada Visões do (des)encanto: um estudo sobre o feminino transgressor em Clarice Lispector e Maria Judite de Carvalho tem por objetivo estudar as personagens femininas das escritoras nas obras Laços de família (1960) e Flores ao telefone (1968), tendo como ponto de partida a relação existente entre a criação das personagens e o papel social vivido pela mulher em tal época. O projeto literário das duas autoras caminha atento às mudanças sociais e a transformações ocorridas no universo feminino, surgindo então a necessidade de dar voz às mulheres através de suas figuras ficcionais. A oposição entre destino/liberdade é questionada no cotidiano de personagens femininas de classe média acostumadas a viver à sombra do masculino, sem criar um lugar para si no mundo. As autoras lançam um olhar profundo sobre a sociedade, este se reflete nas angústias e malogros de suas personagens que precisam tantas vezes romper com a conduta social para serem livres. Tal processo de transgressão das personagens no universo das duas autoras é estudado tendo como base teórica o estudo sobre os vários aspectos do feminino em O segundo sexo, de Simone de Beauvoir.

Palavras-chaves: Literatura luso-brasileira, Maria Judite de Carvalho, Clarice Lispector, feminino, personagens, vozes narrativas. 


\begin{abstract}
The PhD research entitled Visões do (des)encanto: um estudo sobre o feminino transgressor em Clarice Lispector e Maria Judite de Carvalho aims to study the females characters of these writers in the works Laços de familia (1960) and Flores ao telefone (1968), taking as its starting point the relationship between the creation of characters and women social roles in this epoch. The literary project of two authors talks about the female social changes and transformations, from which appears the need to give voice to women through their fictional figures. The opposition between fate/freedom is discussed in the everyday middle-class female characters used to live in the shadow of men, who do not create a place for themselves in the world. The authors focus on the society, showing the difficulties and failures of their characters that so often need to break with the social conduct to be free. This process of breaking the characters in the univese of the two authors is studied bsed on the theoretical study on various aspects of the feminine in The Second Sex, Simone de Beauvoir.
\end{abstract}

Keywords: Luso-Brazilian Literature, Maria Judite, Clarice Lispector, female, characters, narrative voices. 


\section{RÉSUMÉ}

La recherche de Doctorat qui s'appele Visões do (des)encanto: um estudo sobre o feminino transgressor em Clarice Lispector e Maria Judite de Carvalho a comme objective étudier les personnages féminins dans les oeuvres Laços de família (1960) et Flores ao telefone (1968). Nous avons comme point de départ la relation existente entre la création de personnages et le rôle social vecu pour la femme en tel époque. La conception littéraire de les deux auteurs à pied à l'écoute des changements sociaux et transformations qui se produisent chez la femme, apparaît alors la nécessité de donner la parole aux femmes à travers leurs personnages fictifs. L'opposition entre destin/liberté est contestée dans le quotidien de les personnages féminins de la classe moyenne qui sont habitués à vivre dans l'ombre des hommes, sans créer une place pour eux dans le monde. Les auteurs jetent un regard profond sur la société, cela se reflète dans les difficultés et les échecs de ses personnages qui ont si souvent besoin de rompre avec le comportement social pour être libre. Ce processus de rupture de les personnages de l'univers des deux auteurs est analysé à partir de l'étude de la théorie sur les divers aspects du féminin fait pour Simone de Beauvoir en Le deuxième sexe.

Mots-clés : Littérature luso-brésiliene, Maria Judite de Carvalho, Clarice Lispector, féminin, personnages, voix narrative. 


\section{SUMÁRIO}

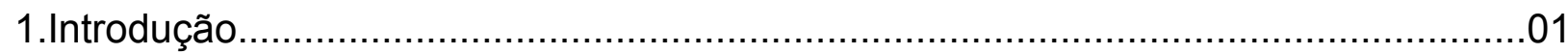

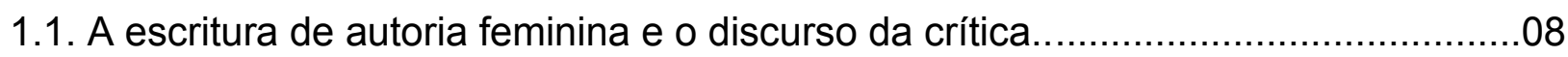

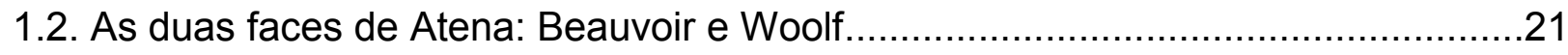

2. Um momento em dois retratos: Brasil \& Portugal...................................................

2.1. Duas escritoras: tramas, traços e caminhos......................................................

2.2. Discreto infinito: a escrita de Clarice Lispector..................................................49

2.3. Tramas e traços: o universo de Maria Judite de Carvalho......................................62

3. Retrato em carne viva: contos e (des)encantos....................................................73

3.1. O mundo entre paredes: mulheres domesticadas................................................. 83

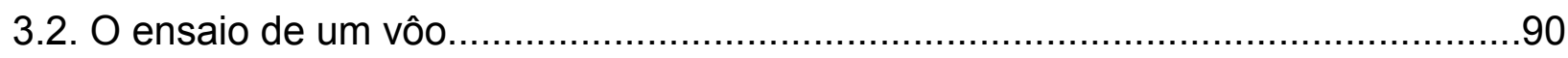

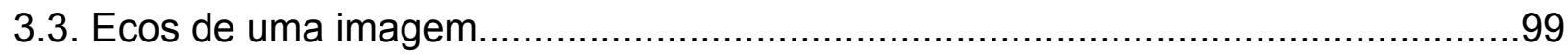

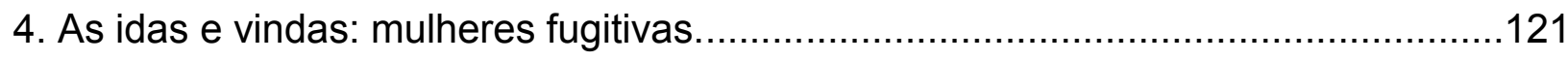

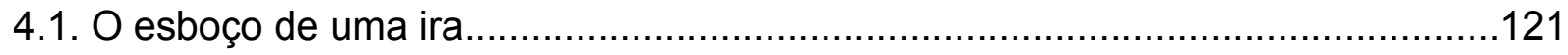

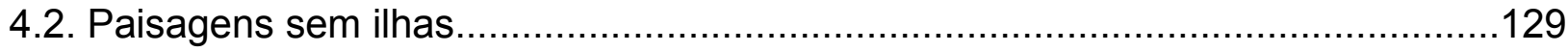

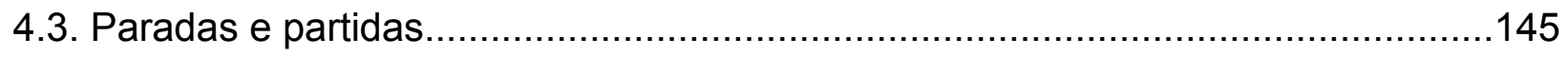

4.4. Desatando os laços: encontros e desencontros..............................................159

5. Tecendo por trás do real: a loucura assistida ..................................................178

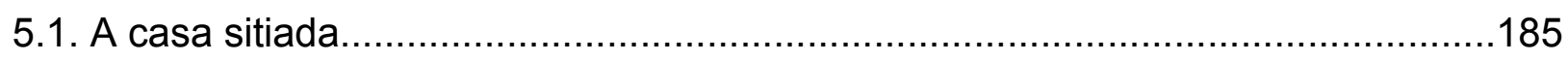

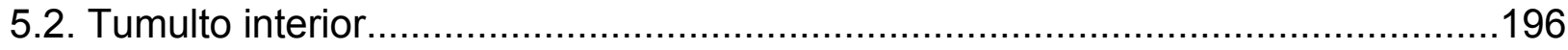

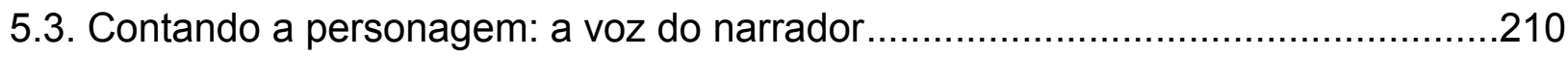

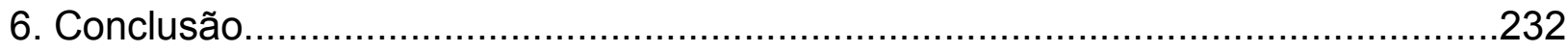

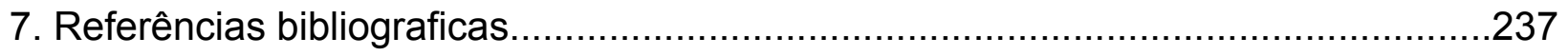

8. Anexo: entrevista com Urbano Tavares Rodrigues...........................................249 
À memória de Benilde Justo Caniato que, com seu talento e generosidade desmedidos, tornou-se minha inspiração para a vida 
Estava melancólica naquele dia porque vira mais uma ruga na superfície lisa do espelho, porque o marido andava longe e ela pouco sabia de sua vida, ela que tanto sonhara com o casal, com os dois amigos, com os dois cúmplices...sentia-se envelhecer e nada do que desejara tão fortemente se havia realizado.

Maria Judite de Carvalho

Minha condição é muito pequena. Sinto-me constrangida. A ponto de que seria inútil ter mais liberdade: minha condição pequena não me deixaria fazer uso da liberdade. Enquanto que a condição do universo. $O$ meu descompasso com o mundo chega a ser cômico de tão grande.

Clarice Lispector 


\section{AGRADECIMENTOS}

À Coordenação de Aperfeiçoamento de Pessoal de Nível Superior, CAPES, pelo apoio financeiro que possibilitou a pesquisa no Brasil e na França;

À Maria Graciete Besse pela generosidade na parceria, amizade, orientação e, principalmente, pelo abraço sempre acolhedor em terras distantes;

À Maria dos Prazeres pela confiança quando tudo ainda era um vestígio, pelas conversas e o apoio que muito ajudaram a construir as veredas e visões no labirinto do texto;

À Claudine Monteil pela contribuição à pesquisa em Paris;

À Urbano Tavares Rodrigues pela gentileza da palavra doada;

À professora Tânia Macedo pelas palavras que no exame de qualificação me deram o norte;

Ao Thierry, amor-maior que, com carinho e cumplicidade, ordenou o caos e renovou a esperança durante esta travessia;

À Guida, "irmãe" tão querida, mulher admirável que tanto me ajudou a sair dos nós do texto;

Aos de "casa", doce refúgio onde sempre me encanto.

À Suzy pelo carinho e pelas tantas vezes que apoiou minhas idas e vindas acadêmicas;

Aos amigos Luciana e Nilson pela leitura dedicada e pelo afeto dispensado. 



\section{Introdução}

Je veux bien que toute écriture soit transgression, et qu'écrire soit pour l'homme aussi enfreindre un interdit. Disons simplement que la transgression sera double ou triple chez la femme.

Béatrice Didier

Observando as obras de Clarice Lispector e Maria Judite de Carvalho, tornase facilmente reconhecível a semelhança entre personagens, enredos, e ainda a recorrência a temáticas como o existencialismo, expresso através da angústia das personagens frente à vida. Temos notícia de que alguns trabalhos comparativos já foram feitos entre as obras das duas autoras, sendo grande parte deles voltados para o estudo do feminino, da solidão, assim como do recorte do olhar nas personagens femininas, o que foi um dos motivos que nos lançou sobre esse tema. Mas dentre tais estudos não consta que algum tenha como objetivo principal a formação de um sujeito feminino que se quer outro, e por isso lança-se para uma existência ampla, transgressora.

Não é de nosso conhecimento até então a existência de um trabalho que, comparando as obras das referidas escritoras, tenha como base teórica os fundamentos propostos por Simone de Beauvoir, em sua obra dedicada ao estudo sócio-histórico da mulher ${ }^{1}$. Assim como as transformações do sujeito feminino, partindo dos argumentos da escritora e ensaísta francesa para uma aproximação entre as realidades sócioculturais de Portugal e do Brasil. É a partir do contexto social em que as personagens estão inseridas que nosso trabalho buscará rastrear as diferentes nuances e transformações ocorridas na construção das personagens femininas na década de 1960 do século passado.

Nosso caminho nessa pesquisa visa justamente a uma continuação dos estudos que já foram feitos sobre a importância e função do olhar nas personagens, mas agora juntando as pontas do filosófico e do social, para analisar a maneira como as personagens tentam caber dentro do "seu espaço" no cotidiano. São mulheres,

\footnotetext{
${ }^{1}$ BEAUVOIR, Simone de. Le deuxième sexe, vols. I et II. Paris, Gallimard, Collection Folio-Essais, 1949.
} 
casadas ou não, às quais muitas vezes é negada a maternidade e, se não o é, também não impede que sofram de uma angústia intensa, por isso fogem para se encontrar, partem para viver paixões. Mesmo aparentemente presas à vida exterior, por qualquer vacilo, seus olhos se voltam para o interior e para o outro, que juntos formam o caminho intenso rumo ao autoconhecimento:

Mas o atalho com sombras refrescantes e reflexo de luz entre as árvores, o atalho onde eu seja finalmente eu, isso não encontrei. Mas sei de uma coisa: meu caminho não sou eu, é outro é os outros. Quando eu puder sentir plenamente o outro, estarei salva e pensarei: eis o meu porto de chegada. ${ }^{2}$

A inserção de um recorte sociológico na análise e aproximação das obras é um aspecto que julgamos relevante, pois o caminho de estudo da transgressão terá como base o momento e estrutura sociais. Partiremos desse veio para mostrar a projeção das transformações na sociedade patriarcal, principalmente no que diz respeito ao universo das personagens femininas. O trabalho mais recente, do qual temos conhecimento, focaliza a influência social no universo das autoras referindo-se mais especificamente às crônicas e não trabalha a ruptura como algo que parte do interior para o meio ${ }^{3}$.

O fato de a pesquisa adotar como base teórica a referida obra de Simone de Beauvoir justifica-se também por ser esse um dos mais importantes estudos no que diz respeito à investigação sócio-histórica sobre a construção do sujeito feminino. Além do fato de ter exercido, nas décadas em que se concentra nosso estudo, grande influência sobre a escrita de autoria feminina no Brasil e em Portugal. O rastrear desse feminino mais questionador, que nega a conduta determinada para a mulher, remete-nos ao universo das personagens femininas de Lispector e de Maria Judite.

O estudo parte de pesquisa bibliográfica sobre vida e obra de Clarice Lispector e de Maria Judite de Carvalho, assim como da leitura de textos das críticas brasileira e portuguesa, ressaltando em particular as abordagens que dizem respeito ao tema por nós apresentado. Faremos também algumas idas à história das mulheres

\footnotetext{
${ }^{2}$ LISPECTOR, Clarice. A descoberta do mundo. Rio de Janeiro, Francisco Alves, 1999, p. 119.

${ }^{3}$ OLIVEIRA, Niube Ruggero. O olhar feminino nas crônicas de Maria Judite de Carvalho e Clarice Lispector. Dissertação de Mestrado apresentada na Faculdade de Filosofia, Letras e ciências Humanas da Universidade de São Paulo, em outubro de 2000.
} 
nas sociedades luso-brasileiras para assim podermos analisar o grau de transgressão denunciado pelos atos de algumas personagens femininas. Em seguida, faremos pesquisa bibliográfica sobre os anos 50 na sociedade francesa no que diz respeito ao papel feminino e acrescentaremos a visão histórico-social exposta por Simone de Beauvoir.

É fato conhecido que a década de 60 foi cenário de grandes mudanças no que diz respeito ao comportamento da mulher na sociedade: o patriarcalismo começou a ser combatido por um desejo de liberdade e um novo olhar sobre a própria condição foi se firmando no meio feminino. É o momento em que as colocações de Simone de Beauvoir em O segundo sexo (publicado em 1949) começam a influenciar a literatura, principalmente aquela escrita por mulheres e que tinha como tema a problemática feminina na sociedade. A proposta feita por Beauvoir, para que a mulher construísse seu destino, era também uma sugestão para romper com o conceito que a sociedade masculina criara para definir a anatomia de "ser" mulher: "La place de la femme dans la société est toujours celle qu'ils lui assignent; en aucun temps elle n'imposé sa propre Ioi." (BEAUVOIR, 1949, vol. I, p. 132)

A literatura feita por mulheres nesta época traz como traço marcante a problemática "transgressora que se manifesta através de uma linguagem também transgressora das normas consagradas", com clara intenção de "dar voz ao ainda informe, à nova consciência-da-condição de mulher ainda em germinação”, sendo portanto uma escrita "fundadora (...) instauradora de uma realidade outra" Surgem dessa realidade as crises existenciais e os questionamentos que as personagens femininas aqui estudadas apresentam de maneira tão intensa.

A transgressão surge também como conseqüência da necessidade de descobrir-se autora de si mesma, o que surge geralmente como conseqüência de um olhar repentino que as personagens lançam sobre o universo que está ao seu redor. 0 convite de Beauvoir direciona-se para a construção de um sujeito feminino que se faz à revelia daquele traçado pelo homem. Elencando direitos como o de ter uma vida

\footnotetext{
${ }^{4}$ O lugar da mulher na sociedade será sempre estabelecido por ele [homem], em época alguma ela impôs sua própria lei. (As traduções da obra de Simone de Beauvoir assim como dos demais teóricos franceses são nossas). ${ }^{5}$ COELHO, Nelly Novaes. "O discurso-em-crise na literatura feminina portuguesa". In Revista Via Atlântica, Publicação da Área de Estudos Comparados de Literaturas de Línguas Portuguesa, Departamento de Letras Clássicas e Vernáculas, Faculdade de Filosofia, Letras e Ciências Humanas da Universidade de São Paulo, n. 2, 1999, p. 120-128.
} 
política e uma educação que fossem relativas ao homem, assim como, a posse dos próprios sonhos, não mais dependentes das limitações impostas pelo outro. Esse seria o caminho para "o ser livre", pois também a existência social era vista como princípio da dependência da mulher:

Le privilège economique détenu par les hommes, leur valeur sociale, le prestige du mariage, l'utilité d'un appui masculin, tout engage les femmes à vouloir ardemment plaire aux hommes. Elles sont encore dans l'ensemble en situation. II s'ensuit que la femme se connaît e se choisit non en tant qu'elle existe pour soi mais telle que l'homme la définit ${ }^{6}$ (BEAUVOIR; vol. II: 234)

A escritora e ensaísta francesa propõe uma ruptura com o legado social que durante toda a história limitou os direitos da mulher, porém tal rompimento só seria possível se a mulher assumisse uma nova posição, podendo assim abandonar a posição de sombra do sujeito masculino. As propostas feitas por Beauvoir que, como já dissemos, influenciam bastante a literatura a partir dos anos 60 , também vão refletir-se nos enredos de Clarice Lispector e Maria Judite de Carvalho.

As vertentes que apontamos na elaboração de nosso trabalho orientam-se também em ensaios como o de Regina Pontieri ${ }^{7}$ sobre a construção de uma poética do olhar em $A$ cidade sitiada de Clarice Lispector, um estudo que se aprofunda na importância fenomenológica do ver na obra da autora, e que também pode ser empregado para análise do tema em algumas obras de Maria Judite de Carvalho. Segundo Pontieri, a construção do olhar em Lispector tende a deslocar sua ênfase "do sujeito que olha para o objeto do olhar", havendo momentos em que a carga subjetiva recai com maior força sobre aquilo que é olhado.

Recorremos também a alguns conceitos de Marilena Chauí que definem o olhar como possibilidade de redimensionar o real, romper com o próprio ser e recriar uma realidade mais intensa e de descobertas, conduzindo as personagens a uma espécie de choque, produzindo uma renovação dos acontecimentos ao redor delas:

\footnotetext{
${ }^{6} \mathrm{O}$ privilégio econômico detido pelos homens, seu valor social, o prestígio do casamento, a utilidade de um apoio masculino, tudo impele as mulheres a desejarem ardorosamente agradar aos homens. Em conjunto elas ainda se encontram em situação de vassalas. Disso decorre que a mulher se conhece e se escolhe, não tal como existe para si, mas tal qual o homem a define.

${ }^{7}$ PONTIERI, Regina. Clarice Lispector:Uma Poética do Olhar. São Paulo: Ateliê Editorial, 1999.
} 
"Porque cremos que a visão se faz em nós pelo fora e, simultaneamente, se faz de nós para fora, olhar é, ao mesmo tempo, sair de si e trazer o mundo para dentro de si" ${ }^{\prime \prime}$.

O novo universo resgatado através do olhar é a estrada por onde essas mulheres andarão, por isso o estudo dessa nova visada será o ponto de partida para a análise do processo que transforma e transpõe as personagens femininas para uma nova condição. Esse novo estar no mundo pode ser abordado por três visadas diferentes: em relação a si mesma, ao mundo e ao outro. Vendo-se com outra perspectiva, os espaços ao seu redor passam a ser estranhos, e a realidade se mostra com seus pormenores a revelar no embate com o outro a falência das relações sociais.

O que é visto no exterior vai causar mudanças no interior das mulheres do universo de Maria Judite e de Clarice: quanto mais é possível ver, mais luz é lançada sobre as coisas e as pessoas, levando a uma busca de justificativas na própria existência. No entanto, a análise das obras também nos permite apontar pontos de divergência, pois para as personagens juditianas não há como voltar de um presente fadado à angustia: na impossibilidade de se reconstruir a vida, a saída será a morte. Nos enredos clariceanos, a possível solução está justamente em retornar, agarrar-se ao que se repete e retomar o cotidiano, será muitas vezes para essas mulheres a única possibilidade de viver.

Tais convergências e divergências serão quase sempre seguidas pelo processo de modificação através do olhar que acima citamos, situação que se passa com as personagens femininas, e que pode ser vista como um divisor, repartindo a realidade entre um antes e um depois. $O$ ato de ver parte do interior dessas mulheres $\mathrm{e}$ chega ao exterior: à opressora condição social, como muros ao seu redor, e volta para a personagem trazendo-lhe a vida em toda a sua crueza. Eis uma das causas da melancolia, solidão e silêncio que fazem transgressor o existir das personagens tanto em Clarice Lispector quanto em Maria Judite de Carvalho, e que são um quadro da mulher nas sociedades brasileira e portuguesa na segunda metade do século XX.

\footnotetext{
${ }^{8}$ CHAUI, Marilena. "Janela da alma, espelho do mundo", in O olhar. Org. Adauto Novaes. São Paulo, Companhia das Letras, 1988, p. 33.
} 
Uma das características da ficção é poder retratar ou recontar uma sociedade, partindo da realidade e levando em consideração um determinado momento. A esse primeiro aspecto podemos também juntar o fato de que a literatura espalha ainda as angústias e anseios do homem e de sua condição e co-existência, por isso relações sociais, trocas, comportamentos e leis que regem essas condutas são alguns dos parâmetros que podem ser observados no eixo dos estudos de literatura e sociedade.

Nosso estudo não pretende defender a existência de uma literatura feminina, tampouco classificar as obras aqui analisadas como parte de tal literatura. O que enfatizaremos em nossas análises é o eixo entre os estudos sócio-históricos sobre o feminino e as narrativas produzidas pelas autoras em questão. Para tanto, serão referência para nossas análises as diversas obras produzidas pelas autoras nos anos de 1960 e posteriormente, em 1970, época em que se fortaleceram os estudos feministas.

Depois de uma abordagem mais geral, passaremos a analisar como se apresenta essa escritura durante a referida década e qual o retrato social que é possível ver através dela, principalmente nas obras das escritoras brasileira e portuguesa que aqui serão estudadas. Nossas análises se direcionarão para as personagens, ressaltando conflitos existenciais e a dificuldade nas relações social e consigo mesma. Para tal investigação lançaremos mão de alguns trabalhos teóricos e críticos pertencentes à linha de estudos franceses, que tem por objetivo tratar o universo da escrita de autoria feminina em um caminho guiado pela filosofia e pela psicanálise como ferramenta para explicar o que move a voz e o desejo de grito dessas personagens.

O eixo da relação feminino/sociedade/história na literatura também será um dos pontos e orientação para a trajetória de nosso trabalho, que começará por uma certa contextualização dos estudos sobre o feminino, seguido por teorias sobre a escritura de autoria feminina para então passarmos para a análise das obras e a relação com a base teórica escolhida. Levando em consideração as convergências e divergências com o objetivo de aproximar os perfis, focando as diversas categorias sociais que são abordadas tanto por Clarice Lispector quanto por Maria Judite de Carvalho. 
Quanto à temática, a análise das personagens enfatizará a mulher que se confina, tornando-se vítima do trabalho doméstico e da falta de papel social. Dentro desse aspecto, será de grande importância o espaço através do ambiente da casa ou do quarto. Em seguida, enfocaremos a figura da mulher que tenta transgredir e lutar para vencer a condição, implicando tal luta, muitas vezes, fugir ao casamento ou à maternidade. O que resulta na crise para vencer a desordem interior, quer seja através da excessiva ordenação do espaço ou da saída para uma realidade inventada, como ponto de refúgio para as personagens. Aproximando estes fatores, ressaltaremos os principais conflitos que tanto atormentam o feminino ainda na segunda metade do século $X X$.

O primeiro capítulo constará da aproximação de algumas idéias fundamentais sobre o universo feminino e sua construção no aspecto histórico-social, seguida das características referentes às sociedades brasileira e portuguesa. Em seguida, faremos a apresentação da fortuna crítica para sustentar as características e particularidades da escrita de cada autora que será por nós comentada. A segunda parte será constituída da análise de alguns contos, por meio das quais rastrearemos os vestígios da formação do feminino e os caminhos da transgressão.

A escolha dos contos que aqui serão apresentados resulta de uma longa leitura das obras das autoras, com o intuito de melhor construir nossa argumentação. Por isso partiremos de uma análise mais aprofundada de tais narrativas para as várias incursões nas demais obras das autoras. As leituras terão uma perspectiva inicial e a verticalização seguirá as marcas da personagem feminina, o que será feito para melhor encaminhar o trabalho pela linha dos objetivos aqui apresentados. Portanto, o percurso do nosso trabalho andará entre o social e o feminino, no entanto a questão lingüística não será aqui recorrente, apesar de esta ser muito forte na escritura de autoria feminina, mesmo que por vezes sutilmente encaixada nas entrelinhas, há nesta escrita uma tendência à denúncia de questões sociais como a da alienação da mulher e a da devoção ao silêncio. 


\subsection{A escritura de autoria feminina9 ${ }^{9}$ o discurso da crítica}

Il faut que la femme s'écrive: que la femme écrive de la femme et fasse venir les femmes à l'écriture, dont elles été éloignées aussi violentement qu'elles été de leurs corps; pour les mêmes raisons, par la même loi, dans le même but mortel. Il faut que la femme se mette au texte - comme au monde, et à l'histoire, - de sont propre mouviment. ${ }^{10}$

A Europa foi um importante cenário para o avanço dos estudos femininos, assim como para as lutas de mulheres pela igualdade de direitos, e no contexto europeu os estudos franceses destacaram-se nas abordagens lingüísticas e filosóficopsicanalíticas, representados por nomes como Hélène Cixous, Catherine Clément, Julia Kristeva, entre muitos outros. A temática de tais estudos orienta-se também na tentativa de explorar as causas da desigualdade entre os sexos e a defesa do respeito às diferenças. Os estudos críticos ligados a esta vertente fundamentam-se, segundo Isabel Allegro de Magalhães ${ }^{11}$, na busca de uma identidade própria para o feminino, representada pela linguagem como caminho para a transgressão.

Preocupam-se com a definição de uma identidade feminina e com as suas realizações simbólicas, procurando encontrar uma linguagem própria para as experiências do corpo e da intersubjectividade, deixadas mudas pela cultura dominante. (MAGALHÃES, 1995, p. 19)

A crítica anglo-americana marcha por caminho diferente e volta-se para questões como a opressão social enfrentada pelas mulheres, analisando-se os textos como reivindicação e protesto contra a submissão feminina. Diferentemente desta, a crítica francesa se preocupará em analisar mais a linguagem do que o conteúdo dos textos. Mesmo havendo diferenças marcantes entre uma e outra corrente crítica, as

\footnotetext{
${ }^{9}$ A preferência pelo termo escritura de autoria feminina seguira ao longo de todo o nosso texto, o que se justifica no fato de que não pensamos aqui defender uma literatura feminina e nem pensamos que tal seja possível. Portanto nos parece mais apropriado nos reportarmos a uma escritura construída pelo feminino mas que não pode por isso aceitar uma nomenclatura que a diferencie daquela escrita por homens.

${ }^{10}$ CIXOUS, Hélène. «Le rire de la Méduse ». In Simone de Beauvoir et la lutte des femmes, ${ }^{\circ}$ 61, Paris: L'arc, 1975.

${ }^{11}$ MAGALHÃES, Isabel Allegro de. O sexo dos textos. Lisboa : Editorial Caminho, 1995.
} 
duas apontam para o considerável crescimento da escritura de autoria feminina na segunda metade do século $X X$. E o que é ainda mais importante é que a base dos estudos em geral é a literatura de autoria feminina, representada por autoras que deram voz ao silêncio das mulheres. Em relação às duas linhas da crítica:

ambas falam de textos literários de autoria feminina, textos esses em que se inscrevem elementos referentes à opressão e repressão das mulheres, e a sua reação a elas. Falam de textos onde se viabiliza um protesto ou uma ruptura formal com a ordem social e simbólica dominante. (MAGALHÃES, 1995, p. 21)

Além do aumento quantitativo e qualitativo do número de escritoras, outro aspecto ajudou a desencadear os estudos sobre o feminino: a necessidade de romper com a desigualdade social, assunto que durante anos inquietou mulheres que pretendiam reivindicar seus direitos. A ausência de papel social e o pouco acesso da mulher ao mercado de trabalho, ocasionando a dificuldade em obter a independência financeira, também foram alguns dos motivos dessa luta.

É relevante para analisar tal contexto, dentre outros, o estudo do historiador francês Roger Chartier ${ }^{12}$ que discute critérios como o da pertinência da oposição entre masculino e feminino. Segundo o historiador um dos pontos essenciais para que se construa uma história do feminino é não perder de vista sua relação com o masculino, o que se justifica no argumento de que um depende do outro, recusando, portanto, a acusação de incentivar a submissão da mulher em relação ao homem.

A base de apoio para tais argumentos deve estar, segundo o historiador, no código de comportamento partilhado pelos dois sexos, e não em caracterizar as particularidades da mulher a partir das diferenças que esta apresenta. A este pressuposto segue-se o de que muitas vezes a mulher para construir sua identidade segue a estreita conduta imposta pela sociedade e, com isso, dá autonomia ao discurso do masculino: "la construction de l'identité féminine s'enracine dans l'intériorisation par les femmes de normes qu'énoncent les discours masculins" (CHARTIER, 1993, p. 106).

\footnotetext{
${ }^{12}$ CHARTIER, Roger. "Différence entre les sexes et domination symbolique » dans Annales ESC, 48 année, n. 4, juillet-août 1993, in Histoire des femmes, histoire sociale, p. 106
} 
Tal comportamento ocasionou o medo da força simbólica que sempre foi atribuída ao masculino, isto é, a mulher acostumou-se a construir sua identidade, segundo Chartier, sob o reconhecimento da autoridade do homem mais do que este a impunha. Mas na continuidade de seu argumento, o historiador nos explica que mais importante do que enumerar diferenças é voltar-se para as posições políticas, sociais e educacionais que têm sido ocupadas pelas mulheres, e com isso poder buscar um lugar de autonomia na sociedade juntamente com a igualdade de papéis e de direitos.

Esta luta poderia servir como arma para que a identidade feminina fugisse das imposições banais, como aparência física, e da conformidade, pois quanto mais passiva e conivente fosse a mulher com sua condição, mais longe ela estaria de alcançar o seu direito à liberdade e o de conduzir o próprio destino:

des femmes passives, estimées trop aisément consentantes à leur condictions, bien que justement la question du consentement soit tout à fait centrale dans le functionnement d'un systeme de pouvoir, qu'il soit social ou/et sexuel (CHARTIER, 1993, p. 107)

A própria linguagem de dominação construída ao longo dos anos pelo masculino tem sido utilizada como uma espécie de escudo para caracterizar a resistência e os protestos femininos. Para Chartier, a mulher lança mão da dominação do homem para formar seu discurso de defesa: "Les fissures qui lézardent les formes de la domination masculine ne prennent pas toutes la forme de déchirures spetaculaires, ni ne s'expriment toujours par l'irruption singulière d'un discours de refus ou de rejet" (CHARTIER, 1993, p. 108).

O essencial não é remarcar diferenças sejam elas biológicas ou históricas entre homem e mulher, mas de a princípio tentar definir a submissão imposta à mulher como uma violência simbólica, e isso pode nos levar a compreender "comment le rapport de domination, qui est um rapport historiquement, culturellement et linguistiquement construit, est toujours affirmé comme une différence de nature, radicale, irréductible, universelle" (CHARTIER, 1993, p. 108).

Um possível segundo passo para o estudo do feminino seria o de transformar a investigação histórica ou biológica em uma abordagem que tivesse como objetivo o 
estudo da natureza feminina segundo os padrões de divisão social dos papéis e das funções atribuídas à mulher. Desta forma, estaríamos abordando os fatores de uma e outra ciência, porém com um sentido mais abrangente, e sem segregar a mulher à sua natureza ou a discriminações biológicas, contra as quais muito lutaram as líderes dos movimentos feministas.

O discurso que fundamenta a dominação do masculino sobre o feminino é de extrema importância do ponto de vista do historiador e não deve ser deixado de lado, para que se compreenda porque durante tanto tempo tal situação se estabeleceu de maneira cada vez mais forte:

Inscrite dans la pratique et dans les faits, organisant la réalité et le quotidien, la différence sexuelle (qui est assujetissement des unes et domination des autres) est toujours construite par les discours qui la fondent et la legitiment. (CHARTIER, 1993, p. 108)

O confinamento e o trabalho doméstico, além de terem sido pesos que acompanharam a mulher durante toda a sua história, foram também situações que contribuíram, na explicação de Chartier, para que a mulher se distanciasse ainda mais do caminho da resistência e da conquista de direitos. Impedida de ter uma vida social, ou um papel atuante na sociedade, a mulher era colocada sempre em um patamar abaixo ao do homem em relação a sua capacidade sociável. O mais grave é que a maioria das mulheres aceitava essas funções como próprias do seu sexo, conformando-se a tudo sem protestar.

O caminho para compreender como se constrói uma cultura feminina ainda é analisando a relação entre os grupos e também entre os sexos, para assim se ter noção de história, papel social e natureza:

C'est en démêlant les relations qu'elles entretiennent [les differentes modalités du pouvoir des femmes] les unes avec les autres que l'on pourra, pour chaque moment historique, comprendre comme une culture féminine se construit a l'interieur d'un systeme de rapports inégalitaires, comme elle en masque les failles, réactive les conflits, jalonne temps et espaces, comment enfin elle pense ses particularités et ses rapports avec la société globale. (CHARTIER, 1993, p. 109) 
Seguindo uma perspectiva que se aproxima daquela de Chartier, temos o estudo do filósofo francês, Pierre Bourdieu ${ }^{13}$, para o qual o problema da submissão feminina diante da soberania masculina faz parte de um retrato construído menos pelos fatores da natureza biológica, e mais pela sociedade, sendo sustentado pela mulher apenas por uma questão de cumprir seu papel sem maiores incômodos.

As atividades atribuídas e executadas por um sexo ou outro fazem parte de um sistema social criado por uma classe dominante, daí as obrigações dos homens terem sido sempre vistas de alto a baixo em relação às mulheres. Se as leis de conduta foram criadas por aqueles para serem executadas por estas, só possuem validade se inseridas em tal sistema hierárquico. Portanto, tornam-se abstratas se a mulher rompe com tal hierarquia.

Segundo o filósofo, é o próprio sistema social, e sua organização, que constrói as diferentes posições entre homem e mulher, principalmente no que diz respeito ao papel social, à posição a ocupar na família ou até mesmo ao grau de participação na vida sociopolítica de um determinado lugar. A análise deste sistema de deveres desiguais será de grande importância para entendermos, segundo Bourdieu, a relação de dominação do homem sobre a mulher, uma vez que:

c'est lui qui construit la différence entre les sexes biologiques conformément aux principes d'une vision mythique du monde enracinée dans la relation arbitraire de domination des hommes sur les femmes, elle-même inscrite, avec la division du travail, dans la realité de l'ordre social. (BOURDIEU, 1998, p. 16)

Observamos que para Bourdieu é o princípio da visão social que constrói e determina o papel ocupado por homem e mulher. Surgindo desta visão diferenças como as que dizem respeito à natureza, ao papel social ou à divisão do trabalho. Ao lado de tais divisões sociais, construídas sob desigualdades, temos também a questão das normas de comportamento, estabelecendo parâmetros para limitar o pensamento dentro das evidências das relações de dominação do masculino sobre o feminino. $O$ que nos permite dizer que a dominação parte de uma exigência de lugar social e que

\footnotetext{
${ }^{13}$ BOURDIEU, Pierre. La domination masculine. Paris: Éditions du Seuil, 1998.
} 
este irá determinar os passos que a mulher deverá ou não dar, segundo sua condição. Tudo que ultrapassar tais limites será transgressão.

Para seguir os costumes, a mulher deveria aceitar a dominação em todos os domínios de sua existência, principalmente o sexual, no qual não podia expressar qualquer tipo de soberania. A instituição de uma posição sexual contribuiu durante séculos com esta dominação corporal, garantindo ao homem sempre exercer o papel daquele que do alto deposita a vida no lugar possuído pela fêmea.

Na posição tradicional ela constrói sua imobilidade em relação à mobilidade do outro e, nesse aspecto, prevalece o fato de o homem submetê-la ao poder masculino. Bourdieu nos explica porque o ato sexual pode também servir de representação para explicar esta relação de domínio:

Si le rapport sexuel apparaît comme um rapport social de domination, c'est qu'il est construit à travers le príncipe de division fundamentale entre le masculin, actif, et le feminin, passif, et que ce príncipe crée, organise, exprime et dirige le désir masculin comme désir de possession, comme domination erotisée, et le désir féminin comme désir de la domination masculine, comme subordination erotisée, ou même, à la limite, reconnaissance erotisée de la domination. (BOURDIEU, 1998, p. 27)

Analisar alguns retratos que foram construídos pela sociedade para a mulher é tema principal no ensaio de Hélène Cixous ${ }^{14}$.A ensaísta começa por analisar à luz da psicanálise e da filosofia os diversos tipos de feminino criados segundo os modos de comportamento. Tais conceitos levam em consideração as heranças de Eva e Lilith; assim, temos a mulher feiticeira, a sofredora e a histérica, conceitos criados por homens com a função de limitar ainda mais a existência da mulher. Será este o ponto de partida para que Cixous nos explique alguns caminhos que levaram à criação de imagens retorcidas sobre o feminino.

É possível conhecermos também a trajetória dos conceitos e comportamentos os quais as mulheres deveriam seguir; critérios que explicam a maneira profunda com que se arraigaram leis e comportamentos para arraigar a existência da mulher à dependência. Esse era o principal intuito dos tantos códigos de comportamento

\footnotetext{
${ }^{14}$ Lembramos que Cixous foi uma das primeiras teóricas francesas a estudar a obra de Clarice Lispector, publicando ensaios críticos e a ministrando cursos na França a partir dos anos 60.
} 
sempre determinados pelo homem, o pouco permitido e o muito proibido. Tanto a feiticeira quanto a histérica eram classificadas como perigosas para a sociedade, pois poderiam distorcer os valores que tão bem foram pensados para elas; deveriam se manter separadas das demais, para então serem combatidas ou curadas:

Car la sorcière guérit, contre l'église; elle avorte les femmes, favorise l'amour non conjugal, ménage l'invivable espace d'un christianisme étouffant. Car l'hystérique défait les liens familiaux, introduit la perturbation dans le déroulement réglé de la vie quotidienne, suscite la magie dans l'apparente raison ${ }^{15}$.

Seja qual for o título, feiticeira, mística ou histérica, vemos com Cixous que a mulher que se negava a controlar suas emoções e que não suportava a pequena condição deveria ser banida. Essa cura, muitas vezes, implicava medidas radicais, como as feiticeiras queimadas na Idade Média em toda a Europa, ou as histéricas tratadas com choques elétricos até meados do século XIX:

Innocente, folle, pleine de souvenirs mal rememores, coupable de fautes inconnues, telle est la sédutrice, héritière de toutes les Ėves génériques. L'une comme l'autre, la sorcière comme l'hysterique, marquent à leur façon la fin d'une norme. (CIXOUS, 1975, p. 13)

Seguindo o pensamento de Cixous vemos que a alienação ou loucura relacionada ao feminino é ainda mais preocupante socialmente à medida que ela questiona a sociedade em vigor. A ensaísta francesa alia seu pensamento ao de Claude Lévi-Strauss ${ }^{16}$, afirmando que a anomalia da loucura pode ser vista como um meio de segregação e que os loucos são também considerados uma espécie de classe revoltosa, de resistentes a um regime de opressão. Mas que culturalmente jamais serão reconhecidos como tal, sendo não mais que um grupo imaginário.

Tal como os loucos que imaginam ser tudo aquilo que não o são, as mulheres apontadas como loucas muitas vezes são apenas portadoras de um desejo incontido

\footnotetext{
${ }^{15}$ CIXOUS, Hélène et CLÉMENT, C. La jeune née. Paris : Union Générale d'Éditions, 1975.

${ }^{16}$ LÉVI-STRAUSS, Claude. "Le totémisme aujourd'hui”, in Oeuvres, Paris: Éditions Gallimard, 2008.
} 
de serem outras, de estarem além, distante daquilo que são obrigadas a ser: "Et, plus que toutes ceux-là, les femmes incarnent bizarrement ce groupe d'anomalies qui montre les filles d'un système d'ensemble" (CIXOUS, 1975, p. 16).

Segundo a teoria do antropólogo Lévi-Strauss, há duas modalidades de repressão/integração: a antropoêmica que consiste em segregar o indivíduo dito "anormal", ou diferente do comum, em hospitais, asilos, cadeias, etc. A segunda, antropofágica, consiste em encontrar um lugar na anomalia ou marginalidade para classificar o ser diferente do grupo, por isso a necessidade de marginalizar aquelas mulheres que decidem não se conformar com sua condição. Algumas são denominadas loucas, sendo trancadas em um asilo; outras, vistas como revoltadas, revolucionárias, classificadas como alguém de caráter duvidoso.

A histeria é classificada ainda hoje como um mal feminino fortemente combatido pela sociedade, a mulher histérica é vista como desregrada, fora do caráter calmo que deveria ser assumido por ela, sobretudo se analisada no centro das leis comportamentais dominantes. Portanto, a ligação do feminino com a loucura, ou com a histeria, foi sempre combatida com métodos violentos e chocantes. A histérica deveria, acima de tudo, sentir-se culpada por representar um desregramento nos costumes femininos.

Além de analisar a loucura como manifestação de resistência do feminino, Cixous ressalta uma característica importante, que sempre esteve presente na sociedade feminina, a questão do duplo como representação da mulher: mal/bem, anjo/demônio, ativa/passiva, racional/sentimental, opostos que nos remetem novamente à questão do duplo Eva/Lilith. Esta classificação desigual foi uma das responsáveis pelos dois principais eixos do conflito feminino: o da mulher que se entrega à condição imposta, abandona a si mesma, para seguir seu papel social; e aquela que não aceita os limites e as restrições e resolve tomar para si seu destino.

De tal duplicidade de comportamentos o fato de a mulher habitar por vezes na fronteira entre o desejo de liberdade e a castração, pois se de um lado ela procura exercer seu direito de ser livre, por outro lado tenta não perder o caminho de sua condição. Quando decide romper com o conflito e seguir livre, é acusada de pertencer ao mundo dos homens, de ter tentado sair de si para atingir o outro sexo: "homem de 
saias", "mulher de bigodes", "espírito masculino"17 são expressões freqüentes para classificar essa parte do feminino que tenta fugir ao destino premeditado.

A oposição destino-liberdade tem sido tema de várias obras literárias, entre elas Orlando, de Virginia Woolf, que construiu uma das personagens mais polêmicas no que diz respeito à representação do duplo e à retratação das inquietudes do feminino. Ao nascer homem e em certa altura tornar-se mulher, a personagem Orlando pode melhor definir as angústias e restrições às quais estava submetida. Tendo provado da liberdade de uma vida sem limites, a bela mulher não conseguia caber na postura dócil e frágil que era exigida de uma jovem burguesa na Londres da época, e tentava repetidamente vencer seus conflitos:

Sentiu-se envenenada de alto a baixo e foi forçada, afinal, a pensar no mais desesperado dos remédios, que era render-se completamente e submissamente ao espírito da época e arranjar um marido. ${ }^{18}$

Ao analisar a representação do feminino em diferentes domínios da ciência, a pesquisadora francesa explica que em todos eles o papel que coube à mulher foi sempre o de passividade. Na história da filosofia, por exemplo, a mulher é citada sempre como ser de sentimentos, mas nunca de atitudes, sendo por isso alguém distante dos domínios do pensamento filosófico.

Abordagem semelhante foi feita anos antes por Simone de Beauvoir quando em o Segundo sexo dedica um capítulo a analisar o "destino" das mulheres nas diferentes ciências ${ }^{19}$. Cixous trilha um caminho diferente daquele percorrido por Beauvoir, e vai buscar nas fábulas infantis, como $A$ bela adormecida ${ }^{20}$, o princípio que constrói nessas antigas narrativas a questão da submissão feminina.

O homem, além de ser quem vem para libertá-la do sono, trazê-la de volta ao mundo, é aquele que traz consigo a promessa de felicidade para sempre. E ao acordar, o mundo da personagem se resumirá na figura do homem para quem ela vivera, ou dormira, até então. Esta mulher então passará, como muitas outras, de

\footnotetext{
${ }^{17}$ ROCHA-COUTINHO, Maria Lúcia. Tecendo por trás do real: a mulher brasileira nas relações familiares. Rio de Janeiro: Rocco, 1994.

${ }^{18}$ WOOLF, Virginia. Orlando. Trad. Cecília Meireles. São Paulo, Abril Cultural, 1972, p. 350.

${ }^{19}$ BEAUVOIR, Simone. "Destin", in Le deuxième sexe, vol. I. Paris : Gallimard, 2006.

${ }^{20}$ PERAULT, Charles. La belle au bois dormant. Paris: Gallimard, 1931.
} 
cama em cama, da cama em que dormia à espera do homem, à cama em que terá seus vários filhos e, finalmente passará à cama de morte. Portanto, nenhum papel de ação lhe é atribuído.

O contexto da fábula é abordado por Cixous como ponte para chegar ao perfil feminino criado no decorrer dos anos, firmado na segregação seja no mundo do sono ou da cegueira. Assim, durante muito tempo, a mulher se acostumou a passar sua existência a desabar das ilusões, a seguir um destino determinado, sem questionar direitos ou posições sociais diferentes.

O destino sempre ligado às histórias de amor tem sido uma armadilha mistificadora para o feminino, imputando-Ihe a natureza sentimental de razão ausente e docilidade ingênua. Essa caracterização colocou a mulher para fora da sociedade e da cultura, como alguém que só precisa alimentar o coração e os sonhos, para quem a reflexão e as ciências não valem muito. No entanto, não podemos deixar de lembrar que ao longo da história essa situação foi sendo questionada e superada por algumas mulheres que insistiram em ser sujeito e assumir um papel ativo na sociedade e na intelectualidade de seu meio, mesmo em tempos em que a autonomia feminina não passava de utopia.

Entre tais mulheres estão Lou-Andreas Salomé, Georg Sand, Virginia Woolf, Simone de Beauvoir, ou ainda as escritoras portuguesas conhecidas como "as três Marias" que ousaram em linguagem e em contexto no livro Novas cartas portuguesas ${ }^{21}$, tendo coragem de se pronunciar a respeito das restrições e das regras desiguais que regiam o mundo feminino. Desta obra e sua importância nos estudos sobre o feminino, falaremos mais adiante.

Além de um papel social, havia também o papel religioso que era imposto à mulher. Segundo os parâmetros da igreja, ela deveria temer a rua, ter pavor da noite, de chuvas e tempestades, e ainda deveria ter desgosto e vergonha dos atos desrespeitosos das outras mulheres. Tal quadro contribuiu ainda mais para que a sociedade dos homens fabricasse as mulheres antinarcisistas, ensinadas a brigar

\footnotetext{
${ }^{21}$ BARRENO, Maria Isabel. HORTA, Maria Teresa. COSTA, Maria Velho da. Novas cartas portuguesas. Rio de Janeiro, Nórdica, 1972.
} 
contra seu corpo, a se esconder, ou a perder a noção de liberdade, tornando-se juizas de si mesmas.

É possível observar com as abordagens de Cixous que a história da mulher se construiu em torno de um misticismo criado e determinado pelo homem, e que nessa história ela nunca teve o direito de intervir. A teórica francesa resume a criação da identidade feminina através de um questionamento que nos faz ver como se desenhou a figura feminina sob o contexto do trinômio mundo/homem/mulher:

Est-ce que c'est moi, ce non-corps habillé, enveloppé de voiles, éloigné soigneusement, tenu à l'écart de l'Histoire, des transformation, annulée, maintenue en marge de la scène, côté cuisine ou côté lit ?" (CIXOUS, 1975 , p. 27).

O último ponto relacionado por Cixous fundamenta-se na relação entre o senhor e o escravo descrita por Hege ${ }^{22}$. Tal qual o mestre cria regras através das quais vai garantir a permanência da submissão do seu escravo, assim também, e com intenção parecida, foram elaboradas as leis que regem o feminino, garantindo aos homens a submissão das mulheres.

Para Cixous, essa teoria explicada pelo filósofo alemão pode ser encontrada também nas relações sociais entre minorias discriminadas e maiorias dominantes, assim como a relação do submisso de ir rumo ao outro para voltar a si mesmo na tentativa de melhor se entender. Observamos então que a mulher busca com mais freqüência no outro, o homem, encontrar a si mesma. Tal busca pode ser feita através da junção total com o outro, de sê-lo ou praticá-lo para melhor senti-lo.

Cixous nos afirma que, de fato, os grandes teóricos que ao longo da história têm se ocupado das relações humanas, ou entre classes, nada inovaram em suas teorias sobre o eu que busca encontrar-se no outro. Mas sim tiveram como base as relações tomadas de cima para baixo, como as do Estado com a família ou as do homem com a mulher:

Tous les grands théoriciens du destin ou de l'histoire humaine ont reproduit la logique du désir, la plus ordinaire, celle qui retien le

\footnotetext{
${ }^{22}$ A esse respeito ver HEGEL, F. Fenomenologia do Espírito. Trad. Paulo Meneses. Rio de Janeiro, Editora Vozes, 1992.
} 
mouvement vers l'autre dans une mise en scène patriarcale, sous la loi de l'Homme" (CIXOUS, 1975, p. 32)

Se analisarmos as estruturas sociais, econômicas e históricas vemos que em todas elas há sempre a preocupação de estabelecer e frisar as diferenças entre como se deveria apresentar o mundo para o masculino e para o feminino. O que tem sido ao longo da história a causa direta da angústia de muitas mulheres, posto que tais diferenças ressaltam fortemente a situação de desfavorecimento em que foi colocado o feminino.

Um dos caminhos sugeridos pela autora para corrigir grande parte das diferenças sociais carregadas pelas mulheres é a de repensar toda a ideologia criada em torno dos sexos e da diferença entre eles, assim como pensar as origens para entender o passado e tentar mudar o presente. E este seria também o caminho para a explicação acerca do eterno conflito feminino da falta de liberdade.

Ao longo dos anos, o conflito interior feminino tem sido representado pela questão: como a mulher poderia levar a vida em liberdade e sem tabus? Resolver tal questão poderia the dar o direito de ocupar um papel ativo na sociedade, sem correr sempre o risco de ser rotulada. Tampouco, sem anular as diferenças que sempre existirão entre um e outro sexo no que diz respeito ao olhar social:

Hommes et femmes sont pris dans un réseau de determinations culturelles millénaires d'une complexité pratiquement inanalysable : on ne peut plu parler de "la femme " que de "l'homme » sans être pris à l'interieur d'un théâtre ideologique où la multiplication des représentations, images, reflets, mythes, identifications transforme, déforme, altère sans cesse l'imaginair de chacun et rend d'avance caduque tout conceptualisation. (CIXOUS, 1975, p. 40)

Os diversos estudos referentes à escritura de autoria feminina e sua produção no Brasil foram reunidos em ensaio de Nadia Batella Gotlib ${ }^{23}$. Caracterizando as diferentes obras, a autora nos mostra as várias etapas da escrita de mulheres brasileiras e os aspectos apresentados por cada escritora. O século XIX é o ponto de partida para a análise da condição do feminino em nosso país, passando

\footnotetext{
${ }^{23}$ GOTLIB, Nadia Btella. A literatura feita por mulheres no Brasil. Conferência apresentada ao Centro de Estudos Brasileiros da Universidade Oxford, Londres, 1998.
} 
também pela visão daqueles que vinham de longe e logo percebiam a "distância" em termos de conquistas da nossa mulher em relação à européia.

Um dos pontos tratados pela autora é a aproximação que às vezes é possível constatar entre a escritora e sua obra, isto é, os traços das personagens e os acontecimentos ficcionados são realidades enfrentadas por uma escritora que luta para vencer a condição. A relação entre Macabéa e sua autora é o exemplo citado pela ensaísta:

ambas se encontram num momento crítico da história do contexto de vida da mulher no Brasil, promovido por preconceituosas e injustas desigualdades sociais, pela consideração das diferenças de sexo e pelas múltiplas implicações das questões de gênero, problematizadas no corpo mesmo da representação ou construção simbólica, sob a forma da metalinguagem em arte literária. (GOTLIB, 1998, p. 5 - os grifos são da autora)

O texto de Nadia Gotlib parte da ficção de autoria feminina para abranger também as ensaístas e artistas em geral, assim como os estudos críticos existentes na literatura brasileira. $O$ trabalho de Gotlib é de grande importância também como fonte de informação sobre a produção feminina, e os estudos de teoria e crítica que se desenvolveram aqui.

O silêncio ao qual estava condicionada a mulher fez com que durante muito tempo não tivéssemos registro de uma escritura de autoria feminina, e no Brasil tal silêncio demorou ainda mais para ser rompido. As descrições feitas sobre o mundo ou a condição da mulher seguiam a linguagem dos homens, os desejos ou sentimentos conhecidos vinham sempre de uma tradução masculina.

Relatos de historiadores sobre a sociedade brasileira no início do século $X X$ retratam uma mulher no isolamento do lar e vivendo apenas para cuidar dos outros. Ocupar-se da carreira de filhos e marido, como bem vemos nas mulheres retratadas na obra de Clarice Lispector, era o dever sobre o qual não poderia haver contestação. Mesmo possuindo o direito de ter acesso à educação, para a mulher dos anos 1960, a cultura e a literatura ficaram distantes, por isso escrever para ela era romper com o 
fechado mundo das obrigações, tornando-se também um caminho de resistência e protesto.

Todo o registro feito sobre as atividades intelectuais ligadas ao feminino partia sempre dos homens; pouco se sabia ou se falava sobre escritura de autoria feminina ou qualquer outra manifestação artística produzida pelo feminino. Ao referirse ao trabalho de pesquisa da escritora Lucia Miguel Pereira, Gotlib nos explica que:

Além da ausência da mulher no registro, feito por homens, de produções literárias ao longo da história de nossa literatura, a pesquisadora detém-se em alguns exemplos de ausência da mulher no campo social das atividades artísticas, detectando preconceitos que norteiam o comportamento da mulher no Brasil. (GOTLIB, 1998, p. 9)

A ausência de um papel social atenuará o estado de solidão, que será fruto também das falidas relações sociais e do malogro de viver limitada ao peso da própria condição. Tais conflitos são a matéria recorrente nos enredos vividos pelas personagens femininas das autoras aqui estudadas e de muitas outras escritoras que intensificaram sua produção a partir dos anos 60 do século XX.

\subsection{As duas faces de Atena: Beauvoir e Woolf}

On ne sait plus bien s'il existe encore des femmes, s'il en existera toujours, s'il faut ou non le souhaiter, quelle place elles occupent en ce monde, quelle place elles devraient y occuper.

Simone de Beauvoir

Por que os homens bebiam vinho e as mulheres, água? Por que um sexo era tão próspero e o outro, tão pobre?

Virgínia Woolf

O crescimento dos movimentos de contestação do final dos anos de 1960 coincide com o crescimento das reivindicações e dos vários movimentos femininos. É em meio a protestos nas classes estudantis, dos trabalhadores e de libertação das últimas colônias que encontramos a explosão dos movimentos de união das mulheres 
em prol da luta pelos seus direitos. O que não é fruto do acaso, pois esta última categoria também representava uma minoria submissa a um poder maior: o mundo masculino.

É nesse cenário que várias mudanças vão ocorrer também no âmbito literário. O interesse por dar voz ao marginal, por ver o quadro social de uma outra perspectiva vai valorizar os estudos culturais assim como o estudo do gênero. A crítica se volta para a escrita de autoria feminina, o que se torna parte importante desse novo panorama que valoriza vozes que antes estavam esquecidas.

Toda uma história de submissão e a luta pela emancipação da mulher será analisada sob várias linhas de pesquisa que vão desde o antropológico, passando pelo histórico, sociológico e literário, havendo certamente outros domínios da ciência que aqui não citaremos. Trabalhos antes colocados de lado ou censurados começam a ser revisitados e propagados por centros que tomam a palavra na intenção de defender a importância dos Estudos Culturais e das minorias, como é o caso do feminino:

É precisamente a questão da importância social das Humanidades, a que a Sociologia parecia ter, a certa altura, respondido, que irá desencadear, nos anos oitenta e noventa do século XX, a confluência dos Estudos Literários com os Estudos Culturais ${ }^{24}$.

A efervescência do desejo de mudança da época influenciou a inclinação de várias áreas das ciências humanas para o estudo das minorias. A necessidade de protesto foi o elemento impulsionador do crescimento do número de escritoras e do aumento no interesse sobre assuntos como a condição e a emancipação do feminino. Tabus que desenhavam o papel feminino tais como os ligados à Biologia, a leis e conduta social, que durante anos haviam aprisionado a mulher a uma figura "idealizada", começaram a ser quebrados.

Teorias como a de Simone de Beauvoir passaram a ser analisadas com o intuito de melhor entender como funcionara até então essa espécie de regime ao qual a mulher teria de seguir para ser reconhecida e aceita pela sociedade. Com frases

\footnotetext{
${ }^{24}$ MACEDO, Ana Gabriela e AMARAL, Ana Luísa. Dicionário da crítica feminista. Porto: Edições Afrontamento, 2005, p. 57.
} 
marcantes como a conhecida "On ne naît pas femme: on le devient" (BEAUVOIR, 1949, vol.II, p. 2), a filósofa francesa exerceu um papel de vanguarda em relação aos estudos sobre as diferenças de gênero e de papel social.

É também a idéia de construção do papel social feminino pela diferença, proposta por Beauvoir, que vai conduzir muitos estudos desenvolvidos pelos Movimentos Feministas que se intensificaram a partir dos anos de 1970, e que foram de grande importância como ponto de partida a uma postura de denúncia e de quebra do silêncio que durante anos envolveu a condição da mulher. A atmosfera de ruptura e combate contribuiu diretamente para o fortalecimento dos estudos ligados ao feminino, entre eles o da literatura escrita por mulheres:

Desde que emergem, os Estudos Feministas, enunciam de formas diversas, a constituição do sexo/gênero como categoria de análise (...) a necessidade da desconstrução de saberes dominantes construídos a partir do olhar masculino (...) denunciando os modelos históricos dominantes e interrogando-se sobre a posição das mulheres ao longo da História. (MACEDO; 2005: 58)

A partir do final da década de 40 do século passado tornou-se quase impossível analisar a história do feminino sem se reportar a Simone de Beauvoir. Sua obra polêmica sobre a mulher tem sido citada não só nos mais variados estudos sobre o tema como em palestras, congressos ou encontros que tenham como objetivo discutir o assunto. Com uma longa pesquisa que envolveu Biologia, História, Psicanálise, Filosofia e demais ciências, o trabalho de Beauvoir tornou-se referência também nos estudos sobre a condição da mulher escritora e a resistência que pode nascer dessa literatura. Em uma longa análise sobre as diferentes partes dos dois tomos de Le deuxième sexe, Daniel Armogathe nos explica se tratar de um estudo feito dentro das exigências do século $X X$, atingindo a completude nas abordagens e na discussão aprofundada sobre as difíceis limitações impostas ao mundo feminino:

Analyse complete et cohérente de la condiction féminine à travers les âges et procès du patriarcat, du pouvoir mâle. En partant de quelques postulats fundamentaux, Simone de Beauvoir, accumule en 1000 pages les faits le plus divers à l'appui d'une thèse qu'on peut résumer ainsi: la majorité des femmes a toujours été tenue á l'écart de la marche du monde, parce que les hommes, qui se posèrent d'emblée comme les 
seules responsables, leur réfuserent les possibilité d'une existence autonome ${ }^{25}$

Após mostrar a importância de tal obra, o crítico também lembra que não se deve ignorar a posição política e o lugar de onde fala Beauvoir, pois estes fatores foram, segundo ele, responsáveis por alguns erros cometidos pela autora, dentre os quais o de julgar ao final de seu livro que o caminho para a igualdade entre os sexos seria o de uma sociedade socialista, na qual a liberdade seria conseqüência da igualdade socioeconômica e da autonomia de sujeito:

Um monde où les hommes et les femmes seraient égaux est facile à imaginer car c'est exactement celui qu'avait promis la révolution soviétique: les femmes élevées et formées exactement comme les hommes travailleraient dans les mêmes condictions et pour les mêmes salaires ${ }^{26}$ (BEAUVOIR, 1949, vol. II, p. 643 - o grifo é da autora)

Anos mais tarde, a afirmação foi reconhecida pela autora como sendo improvável, pois observando o regime socialista era possível ver que também suas leis eram criadas por homens e por isso não se preocupavam com a submissão do feminino, e que mesmo nesse regime ainda eram as mulheres que serviam café enquanto os homens discutiam idéias.

Desde o princípio o homem se estabeleceu como principal e essencial na estrutura da família, restando para a mulher apenas o papel de obedecer-Ihe e fazer parte do seu mundo. Este posicionamento foi acentuando as diferenças e desigualdades entre ambos; até mesmo as bases do pensamento, representada na Filosofia, contribuiu para o aumento da desigualdade. E durante muito tempo a sociedade determinou que à mulher seria atribuído mais o sentimento e menos a razão. Essa foi, nas explicações de Beauvoir, uma das principais distinções que muitos filósofos incutiram na mentalidade feminina:

\footnotetext{
${ }^{25}$ AMORGHATE, Daniel et ALBISTUR, Maité. Histoire du féminisme français : de l'impire napoléonien à nous jours. Tome 2. Paris : Éditions des Femmes, 1977, p. 607.

${ }^{26}$ É fácil imaginar um mundo em que homens e mulheres seriam iguais, porquanto é exatamente o que prometera a revolução soviética: as mulheres, educadas e formadas exatamente como os homens, trabalhariam em condições idênticas e por salários idênticos.
} 
«Être femme, dit Kierkegaard, est quelque chose de si étrange, de si mélangé, de si compliqué, qu'aucun prédicat n'arrive a léxprimer et que les multiples predicats qu'on voudrait employer se contrediraient de telle manière que seule une fmme peut I supporter.» Cela vient de ce qu'elle est considérée non positivement, telle qu'elle est pour soi : mais negativement, telle qu'elle apparait à l'homme. ${ }^{27}$ (BEAUVOIR, 1949, vol. I, p. 244)

Para Beauvoir, a posição secundária atribuída ao feminino originava-se de um conjunto de leis e de instituições em geral, assim determinando-se que a mulher correta para estar ao lado do homem era aquela que não só acreditasse como também praticasse esse princípio. Portanto, a filósofa defende que as mulheres também contribuíram para ocupar tal posição, não só por aceitarem exercer o papel de submissão, mas também por tornarem-se juízas daquelas que a ele se recusavam lutando para adquirir direitos iguais aos dos homens:

L'histoire nous a montré que les hommes ont toujours détenu tous les pouvoir concrets; depuis le premier temps du patriarcat ils ont jugé utile de maintenir la femme dans un état de dependance, leurs codes se sont établis contre elle; et c'est ainsi qu'elle a été concrètement constituée comme l'Autre ${ }^{28}$. (BEAUVOIR, 1949, vol. I, 239).

A dependência existencial estendeu-se também à questão da identidade. A mulher habituou-se a ver no outro o caminho para chegar a si mesma, e criando sua identidade, a partir do olhar do outro, ela ajuda a afirmar a idéia de que somente com a ajuda do homem poderia ter consciência de seu eu. A conseqüência desta idéia foi a afirmação do masculino como superior ao feminino, que busca sua identidade na submissão, colocando-se em lugar desprivilegiado. Este foi, segundo Beauvoir, o trajeto que levou as mulheres a se conformarem com a ausência de papel social, de opinião política e de lugar de igualdade em um mundo feito para os homens:

\footnotetext{
27 “'Ser mulher, diz Kierkegaard, é algo tão estranho, tão complexo, tão complicado que nenhum predicado consegue exprimi-lo e que os múltiplos predicados que desejaríamos empregar se contradiriam de tal modo que só uma mulher o pode suportar." Isso decorre do fato de que ela não é considerada positivamente, tal qual é para si, mas negativamente, tal qual se apresenta ao homem.

${ }^{28}$ A história mostrou-nos que os homens sempre detiveram todos os poderes concretos; desde os primeiros tempos do patriarcado, julgaram útil manter a mulher em estado de dependência, seus códigos se estabeleceram contra ela, e foi assim que ela se constituiu concretamente como Outro.
} 
dire que la femme était l'Autre c'est dire qu'il n'existait pas entre les sexes um rapport de reciprocité (...) La dualité que se decouvre sur une forme ou une autre au coeur des collectivités oppose un groupe d'hommes a un groupe d'hommes: et les femmes font partie de biens que ceux-ci possèdent et qui sont entre eux un instrument d'échange ${ }^{29}$ (BEAUVOIR, 1949, vol. I, 239).

O trabalho doméstico tinha como objetivo segregar a mulher ao espaço do lar, composto de ações repetitivas, sem haver necessidade de desenvolver o pensamento. Sendo também nulo em relação à remuneração e ao reconhecimento do trabalho como contribuição para um meio social, tais tarefas diárias não valem a pena enquanto ato de construir. Confinada às paredes da casa e na execução de tarefas solitárias a mulher tende, segundo a ensaísta, à alienação e à angústia de sentir-se inútil socialmente. Por outro lado, é através das suas funções na casa que ela exercerá seu poder, tentando fazer do ambiente do lar seu reino, uma espécie de compensação do estado submisso:

De l'administration de sa demeure, elle tire sa justification sociale; sa tâche est aussi de veilleir sur l'alimentation, sur les vêtements, d'une maniere generale sur l'entretien de la societé familiale. Ainsi se réalise-telle, elle aussi, comme une activité. Mais c'est (...) une activité qui ne l'arrache pas à son immanence et que lui permet pas une affirmation singulière d'elle-même. ${ }^{30}$ (BEAUVOIR, 1949, vol. II, 260)

A possibilidade de um fim para as desigualdades e a liberdade da mulher são prerrogativas que Beauvoir faz ao fim de seu ensaio. A afirmação da igualdade de condições e a possibilidade de a mulher ocupar um papel social digno são propostas defendidas pela filósofa francesa. Podendo haver o reconhecimento da diferença para o feminino, desde que isso não implique submissão, mas sim liberdade de ser diferente, co-existindo como igual:

\footnotetext{
${ }^{29}$ Afirmar que a mulher é o Outro significa que não havia uma relação de reciprocidade entre os sexos (...) A dualidade que se descobre de uma forma ou de oura no centro das coletividades opõe um grupo de homens a eles mesmos: e as mulheres fazem parte dos bens que eles possuem e que pode ser entre eles um instrumento de troca. ${ }^{30} \mathrm{Da}$ administração de sua residência tira sua justificação social; sua tarefa é também atentar para a alimentação, as roupas, e de uma maneira geral para a manutenção da sociedade familiar. Assim ela também se realiza como uma atividade. Mas trata-se (...) de uma atividade que não a tira de sua imanência, que não permite a ela uma afirmação singular de si própria.
} 
D'abord, il demeurera toujours entre l'homme et la femme certaines différences; son erotisme, donc son monde sexuel, ayant ne figure singulière, e saurait manquer d'engendrer chez elle une sensualité, une sensibilité singulière (...) ceux qui parlent tant d' "égalité dans la différence" auraient mauvaise grace a ne pas me accorder qu'il puísse exister des différences dans l'égalité. ${ }^{31}$ (BEAUVOIR; 1949, vol. II: 651).

O debruçar sobre o longo ensaio de Beauvoir nos faz notar a completude e a profundeza das análises que traz sobre a história e a complexa e delicada condição que se criou para as mulheres, assim como as várias recorrências na história para enumerar as regras de conduta que mistificaram seu comportamento e a qualificaram como herdeira de Eva ou de Maria. Também não foram deixados de lado, como vimos nessa rápida apresentação, detalhes referentes ao papel que a mulher desempenhou em prol de manter ou de destruir os mitos comportamentais que se desenvolveram durante toda sua história.

A ensaísta também não esqueceu de fazer referência às mulheres transgressoras ou revolucionárias que construíram páginas inovadoras na história do feminino. O caráter sócio-histórico foi uma das razões para que fizéssemos do presente estudo a base crítico-teórica de nosso trabalho, pois acreditamos conter caminhos detalhados para explicar as angústias e conflitos vividos pelas personagens de Clarice e Maria Judite que serão analisadas algumas páginas à frente.

O final dos anos de 1960 já demonstra algumas pequenas mudanças na conduta feminina, que se mostrariam claras nas sociedades portuguesa e brasileira apenas a partir de 1970. Como conseqüência de mudanças histórico-sociais, as mulheres começam a sair de casa para trabalhar fora, no entanto este é um movimento que acontece muito lentamente e de maneira sempre assistida pela sociedade. O trabalho feminino tinha o objetivo de ajudar a família e economizar para

\footnotetext{
${ }^{31}$ Primeiramente, haverá sempre certas diferenças entre o homem e a mulher; tendo seu erotismo, logo seu mundo sexual, uma figura singular não poderia deixar de engendrar nela uma sensualidade, uma sensibilidade singular (...) os que tanto falam de "igualdade na diferença" se mostrariam de má-fé em não admitir que possam existir diferenças na igualdade.
} 
o futuro enxoval ou preparativos de um casamento, o que continuava sendo o alvo principal para a mulher, como nos explica Maria Lúcia Roca-Coutinho:

Assim, o final da Segunda Guerra assiste na Europa e nos Estados Unidos, a inúmeras mudanças que afetaram diretamente a mulher e o desempenho de seus papéis de esposa e mãe. As jovens começaram a casar mais cedo e, como conseqüência, começaram a ser mães mais cedo do que nos anos anteriores. Tornou-se também mais comum que as mulheres solteiras trabalhassem fora até o casamento, por razões econômicas, especialmente para ajudar na confecção de seu enxoval e na montagem de sua futura casa. ${ }^{32}$

Totalmente direcionada para o casamento, não havia na realidade feminina espaço para uma carreira ou algo que firmasse uma independência. Para as mulheres as etapas sociais a cumprir estavam sempre direcionadas para a criação de uma família, da qual deveriam cuidar incondicionalmente. Este quadro vai se modificar aos poucos a partir dos anos de 1970, sendo ainda cumpridoras de papéis, todavia as mulheres não querem mais parecer com suas mães.

No entanto elas se deparam com a barreira de não conseguir se afirmar em outra posição que não aquela das esposas ou mães dedicadas. Não encontrando um modelo transgressor para seguir, aquelas que tentam negar-se aos papéis determinados tendem a cair na crise de identidade. Algumas assumem a herança histórica da submissão e espelham-se em gerações anteriores, então se casam e seguem seu destino, ainda que fadadas a uma eterna busca de sentido para a própria solidão.

Segundo Betty Friedan ${ }^{33}$, as mulheres jovens e solteiras demonstravam um certo medo do futuro, sobretudo de serem questionadas a respeito de que carreira seguiriam, uma vez que o mercado de trabalho era uma incerteza e a liberdade impunha um alto preço às mulheres da época: “j’ai m’aperçus qu'elles avaient tellement peur de devenir comme leurs mères qu'il leur était impossible de se connaître. Elles avaient peur d'avancer dans la vie" (FRIEDAN, 1964, p. 75). A crise de identidade passa pela difícil escolha entre ter uma carreira e viver na incerteza, ou

\footnotetext{
${ }^{32}$ ROCHA-COUTINHO, Maria Lucia. Tecendo por trás dos panos: a mulher brasileira nas relações familiares. Rio de Janeiro: Rocco, 1994, p. 98.

${ }^{33}$ FRIEDAN, Betty. La femme mystifiée. Paris, Editions Gonthier, 1964.
} 
seguir a um homem e esquecer tudo que aprendeu em seus primeiros anos de estudo, eis a grande crise da jovem.

Durante muito tempo sustentou-se a idéia de que a mulher guardava em seu interior uma dupla existência, oscilando entre os opostos de bem e mal, santo e profano, "princípio e fim". Mesmo surgindo no século XIX, essa é uma abordagem que tem, de diferentes maneiras, atravessado os anos, pois ainda hoje a mulher é classificada como ser ambíguo, com o qual é necessário cuidado especial. Esta conceituação do sujeito feminino é também responsável pela submissão e dependência, atribuindo à mulher uma culpa carregada durante anos:

Vista como uma soma desarrazoada de atributos positivos e negativos, cujos resultados nem mesmo os recursos científicos cada vez mais sofisticados poderiam prever, a mulher transformava-se num ser moral e socialmente perigoso, devendo ser submetida a um conjunto de medidas normatizadoras extremamente rígidas que assegurassem 0 cumprimento de seu papel social de esposa e mãe o que garantia a vitória do bem sobre o mal, de Maria sobre Eva. ${ }^{34}$

A necessidade de classificá-la entre as vertentes de Eva ou Maria, a impedia de construir de maneira independente seu papel de sujeito. Nascer com uma anatomia traçada amputava-lhe a possibilidade de fazer-se mulher segundo seu próprio olhar sobre a vida. Desviar-se do destino determinado era correr o risco de jamais ser aceita pela sociedade ou, ainda, ser vista como alguém que havia falhado ou rompido com a própria natureza, isto é, uma mulher transgressora. A transgressão que durante muito tempo foi traduzida como loucura ou desvario, levou muitas mulheres sãs a serem internadas como loucas ou apontadas como pessoas sem moral $^{35}$.

Para banir Eva e conservar Maria era necessário viver sob os cuidados de um homem, fosse esse pai, irmão, amante ou marido. A ele caberia encaminhá-la e garantir-lhe respeito perante a sociedade, porém a conseqüência seria assumir para si o papel secundário. Sua condição seria a de viver sempre em relação ao outro, que seria sua ligação com os princípios e leis sociais, confirmando assim a dicotomia:

\footnotetext{
${ }^{34}$ DEL PRIORE, Mary. História das mulheres no Brasil. São Paulo, Contexto-Unesp, 2004, p. 332.

${ }^{35}$ Ver a esse respeito Maria Lúcia Rocha-Coutinho (referência completa ao final do trabalho)
} 
"homens, cérebro, inteligência, razão lúcida, capacidade de decisão versus mulheres coração, sensibilidade, sentimentos" (DEL PRIORE, 2004, p. 332).

Teorias limitadoras e uma sociedade com força patriarcal fizeram com que a mulher se habituasse a crer que sua tendência seria mais sentir do que pensar; que aos homens destinava-se a razão e a ela a emoção. É com base nesse princípio que Beauvoir afirma ser a mulher em grande parte responsável pela construção de sua posição secundária e submissa em relação ao pensamento masculino, aceitando a ingenuidade como algo seu, contra o qual nada pode fazer:

L'homme qui constitue la femme comme un Autre rencontrera donc en elle de profondes complicités. Ainsi, le femme ne se revendique pas comme sujet parce qu'elle n'en a pas les moyens concrets, parce qu'elle éprouve le lien necessaire qui la rattache à l'homme sans en poser la réciprocité, et parce que souvent elle se complaît dans son rôle d'Autre. ${ }^{36}$ (BEAUVOIR, 1949, vol. I, p. 24 - os grifos são da autora)

A partir dos anos 70 vemos um considerável aumento do número de escritoras e com isso o crescimento acentuado da escritura de autoria feminina e, como conseqüência, surgiram vários textos a respeito destas mulheres que quebravam a hegemonia de uma literatura produzida em sua maioria por homens. Não por acaso são situações que acontecem paralelas a uma época em que vinham se firmando já os grupos de reivindicação e de luta pelos direitos da mulher.

O termo escritura de autoria feminina, ou écriture féminine, muito utilizado pela crítica feminista francesa dos anos 70 , foi empregado com o intuito de analisar ou problematizar "a especificidade e existência de marcas do feminino no discurso e na escrita de mulheres". No cerne desta questão está o tradicional texto de Virgínia Woolf ${ }^{37}$, com afirmações importantes para o século XX, entre elas a de que a mulher para ser escritora teria que conquistar liberdade financeira e um espaço onde desenvolver seu trabalho. A escritora inglesa foi uma das primeiras mulheres a expor em público,

\footnotetext{
${ }^{36} \mathrm{O}$ homem que constitui a mulher como um Outro encontrará, nela, profundas cumplicidades. Assim, a mulher não se reivindica como sujeito porque não possui os meios concretos para tanto, porque sente o laço necessário que a prende ao homem sem reclamar a reciprocidade dele, e porque, muitas vezes, se compraz no seu papel de Outro.

${ }^{37}$ WOOLF, Virginia. Um teto todo seu. Trad. Vera Ribeiro. Rio de Janeiro, Nova Fronteira, 1985.
} 
durante conferência apresentada em 1928, as dificuldades que se tornavam muros separando a escrita do feminino:

Sendo a estrutura humana o que é, coração, corpo e cérebro misturados e não contidos em compartimentos separados, como sem dúvida serão em mais um milhão de anos, um bom jantar é de grande importância para a boa conversa. Não se pode pensar bem, amar bem, dormir bem, quando não se jantou bem. (WOOLF, 1985, p. 26)

O texto de Woolf apresenta características da gênese da escritura de autoria feminina, as inquietudes que levavam a mulher para a literatura e as limitações que ao mesmo tempo tornavam-se entraves para que sua escrita se desenvolvesse. A falta de acesso e o confinamento traçaram determinadas linhas para essa escrita, e o caráter intimista juntamente com o tom de diário íntimo foram algumas delas.

Como conseqüência de tal confinamento temos a princípio uma literatura voltada mais para o ambiente doméstico, e que por isso será tratada por alguns críticos como literatura "menor", ou ainda uma escritura dita "pelo avesso", mas era também nascida sob o peso da transgressão e com a responsabilidade de existir em um meio dominado por homens ${ }^{38}$ : "quem pode medir o fogo e a violência do coração do poeta quando capturado e enredado num corpo de mulher?" (WOOLF, 1985, p. 64).

A necessidade de uma independência financeira aliada à literatura como fuga do espaço doméstico, tão bem expostas pela escritora inglesa, tornaram-se assuntos bastante revisitados pela crítica ligada aos estudos feministas. Segundo Woolf, as obrigações domésticas funcionavam também como obstáculo para a criação artística, aumentando sobremaneira a sensação de impotência da mulher diante de sua condição. Tal quadro favorecia sua submissão e o reconhecimento da soberania do homem: "Em todos esses séculos, as mulheres têm servido de espelhos dotados do mágico e delicioso poder de refletir a figura do homem com o dobro de seu tamanho natural" (WOOLF, 1925, p.48).

\footnotetext{
${ }^{38}$ Para reforçar seu argumento a escritora inglesa supõe o fato de Shakespeare possuir uma irmã e em rápido enredo demonstra como essa não teria a mínima chance de escrever a obra produzida pelo irmão, pois sendo mulher jamais lhe seria dada a chance de ser poeta, e a dor a levaria ao suicídio, fuga buscadas por tantas mulheres, na ficção ou na realidade.
} 
Reconhecemos que há proximidade entre as questões levantadas pela escritora inglesa, no início do século $\mathrm{XX}$, e algumas das relações histórico-sociais feitas por Beauvoir no final dos anos 40. No entanto, as visões sobre o histórico de submissão do feminino defendidas por ambas seguem caminhos diferentes. Para Virginia Woolf o melhor seria que mulher e homem conservassem suas diferenças, o que garantiria a existência de dois sexos, mantendo a riqueza de cada um deles. Para Woolf, a condição se faz pesar fortemente sobre os ombros da mulher, e por mais que faça será sempre inferior ao homem. A escritora ressalta as particularidades da escritura de autoria feminina como conquistas resultantes da longa busca por uma autonomia. Mas diz também que de fato o reconhecimento dessa literatura ainda é sonho distante, defendendo que a mulher jamais deveria tentar assemelhar sua escrita à masculina, pois, do contrário, perderia os traços de individualidade:

Seria mil vezes lastimável se as mulheres escrevessem como os homens, ou vivessem como os homens, ou se parecessem com os homens, pois se dois sexos são bem insuficientes, considerando-se a vastidão e a variedade do mundo, como nos arranjaríamos com apenas um. (WOOLF, 1985, p. 116).

Já na visão de Beauvoir o indivíduo vem antes do sexo e por isso a igualdade entre homens e mulheres e sua condição de seres humanos sobrepõem-se a qualquer outra classificação. A existência sobrepõe a condição, e ao exercer um papel social a mulher pode conquistar autonomia e respeito às diferenças. Portanto, a filósofa defende que ao feminino o mais conveniente seria buscar a integralidade, seus valores e visão de mundo sem precisar ocultar suas particularidades, isto é, seu argumento valoriza mais o "ser social" e sua existência capaz de vencer qualquer condição:

Assurément la femme est comme l'homme um être humain: mais une telle affirmation est abstraite; le fait est que tout être humain concret est toujours singulièrement situé. (BEAUVOIR; 1949, vol. II: 15)

As diferenças de ponto de vista entre as escritoras inglesa e francesa continuam no que diz respeito ao conteúdo da escritura de autoria feminina e suas diferenças em relação à literatura em geral. Virginia Woolf defende que os escritos de 
autoria feminina seguem o ritmo de confissão e de denúncia, conseqüência do condicionamento a uma existência presa e limitada. Tal diferença se confirma para a autora quando, após a leitura de vários livros escritos por mulheres, tira da estante um de autoria masculina e se dá conta de que:

era delicioso ler-se novamente um texto de homem. Era tão direto, tão reto, depois dos escritos das mulheres. Indicava tanta liberdade pessoal, tanta confiança em si mesmo. Tinha-se uma sensação de bem-estar físico na presença dessa mente bem nutrida, bem-educada e livre, que nunca fora impedida ou contrariada, mas tivera ampla liberdade, desde o nascimento, para estender-se da maneira que bem the aprouvesse. (WOOLF, 1925, p.64)

Na concepção de Beauvoir, a liberdade será o passo principal para que a literatura vença os limites da condição imposta à mulher. Para que a escritura de autoria feminina ganhe os ares de um texto sem limitações ou de caráter autobiográfico, é necessário que sua autora atinja a posição de igual. Somente libertando-se economicamente, pelo saber e pelos valores sociais, ela poderá ir além com seu texto e sua existência, transcender a condição, o lugar secundário, para então transformar a submissão em um caminho rumo à igualdade, seja na vida ou na escritura:

En effet, pour devenir un créateur il ne suffit pas de se cultiver, c'est-àdire d'intégrer à sa vie des spectacles, des connaissances; il faut que la culture soit appréhendée à travers le libre mouvement d'une transcendance; il faut que l'esprit avec toutes ses richesses se jette vers um ciel vide qu'il lui appartiient de peupler; mais si mille liens ténus le rattachent à la terre, son élan est brisé ${ }^{39}$. (BEAUVOIR, 1949, vol. II, p. 627)

Virgínia Woolf sustenta a liberdade econômica como princípio para a mulher escrever seja poesia ou ficção, mas seu intuito é simbólico, pois a necessidade do dinheiro é de fato o poder "contemplar", e ter um espaço "todo seu", a chave de uma

\footnotetext{
${ }^{39}$ Com efeito, para tornar-se um criador não basta cultivar-se, isto é, integrar espetáculos e conhecimentos na vida; é preciso que a cultura seja apreendida através do livre movimento de uma transcendência; é preciso que o espírito, com todas as suas riquezas, se projete num céu vazio que lhe cabe povoar; mas se mil laços tênue o amarram à terra , desfaz-se o seu impulso.
} 
porta atrás da qual possa trancar-se é ter a liberdade e o poder de pensar, realizando no ato ficcional da escrita o produto de sua reflexão. Para Beauvoir, entretanto, o ir à rua e poder participar dos acontecimentos pode intensificar a participação social, aumentando sua liberdade uma vez que as posições sociais e políticas deixariam de chegar a casa pelas mãos do homem ${ }^{40}$.

A aproximação entre as teorias de Beauvoir e de Virginia Woolf nos remete a duas questões muito presentes nos estudos sobre o feminino: a escritura de autoria feminina ligada ao papel social e à literatura como resistência aos limites impostos por tal papel, temas também presentes no livro da professora e crítica literária francesa Béatrice Didier ${ }^{41}$, no qual é possível ver um amplo retrato da escrita de autoria feminina, com várias incursões na história e na estrutura social com o intuito de explicar as características marcantes em diversas escritoras.

Para Didier, uma das marcas dessa escritura é o conflito entre o desejo de escrever e as regras sociais a cumprir, opondo a escrita-liberdade ao destinoopressão, o que tem sido tema freqüente em muitos dos enredos criados tanto por Clarice Lispector como por Maria Judite de Carvalho:

Néansmoins l'écriture feminine semble presque toujours le lieu d'un conflit entre un désir d'écrire, souvent si violent chez la femme, et une societé qui manifeste à l'égard de ce désir, soit une hostilité systématique, soit cette forme atténuée, mais peut-être plus perfide encore qu'est l'ironie ou la dépréciation. (DIDIER, 1999, p. 11)

Ao aproximar a escritura de autoria feminina com aquela feita por homens, Didier nos explica o perigo de limitar a primeira como pertencente a um mundo literário à parte, pois esta seria uma atitude discriminatória da capacidade criadora da mulher. No entanto é preciso admitir e apontar as diferenças existentes entre as duas literaturas; ressaltar o que na escritura de autoria feminina são particularidades e como estas contribuem para nos aproximar da relação existente entre o aspecto social vivido pela escritora e a construção de suas personagens.

\footnotetext{
${ }^{40}$ Para ir adiante nessa comparação indicamos o texto de Nádia Batella Gotlib, "Leituras de feminino: uma história de desrecalque (Virginia Woolf, Simone de Beauvoir, Clarice Lispector)", cuja referência encontra-se na bibliografia do trabalho.

${ }^{41}$ DIDIER, Beatrice. L'écriture-femme. Paris, Presse Universitaires de France, 1999.
} 
O olhar sobre os aspectos sociais e a situação histórica, sob a qual viveu cada escritora, são importantes para se percorrer os caminhos que levam a alguma das temáticas presentes na escritura de autoria feminina. Assim, dentro da produção de tal escritura, que se tornou mais presente na cena literária a partir da segunda metade do século $X X$, todos esses detalhes se tornam importantes para analisar as diferenças entre as diversas obras e, dentro dessas diferenças, não podemos esquecer também de que cada escritura guarda sua particularidade:

Non seulement la societé, mais le passé de chaque femme diffère, ses expériences, ses traumatismes, ses souvenirs sont autres. Autant il est légitime d'analyser l'oeuvre d'un seul écrivain comme un texte unique (...) autant il est arbitraire de considérer l'oeuvre des femmes comme um tissu continu qui permettrait d'établir une thématique commune. ${ }^{42}$ (DIDIER, 1999; 5).

Há que se ter cuidado ao tentar tematizar demasiado o estudo da escritura de autoria feminina, pois, dessa forma, corremos o risco de condicionar ainda mais a mulher a aspectos preconceituosos como os ligados à natureza ou à fisiologia: "Sous pretexte de retenir des thémes exclusivement féminins, ne risquait-on pas de se limiter, et de ramener la femme à une physiologie, ce qui est encore un moyen de l'enfermer et de la limiter"43 (DIDIER, 1999; p. 6).

Ao analisar algumas particularidades em relação às mulheres escritoras, Didier nos explica que a literatura tem sido um lugar de grande conflito para a mulher que decide levar a pena adiante. O desejo feminino pela arte durante muitos anos foi condenável pela sociedade, pois, além de ter o significado de ruptura, implicava um tempo no qual a mulher deveria cumprir seus deveres, como de mãe e dona de casa.

Dentre os obstáculos colocados para a mulher escritora está a situação conjugal. Ao longo da história do feminino, a figura do marido poderia significar anulação total do eu, ou ainda uma vida em relação, tirando-lhe qualquer possibilidade de contemplação e privacidade. O fato de não possuir um tempo para si mesma

\footnotetext{
${ }^{42}$ Não somente a sociedade, mas o passado de cada mulher difere, suas experiências, seus traumas, suas lembranças são outras. Tanto é legítimo analisar a obra de um só escritor como um texto único (...) quanto é arbitrário considerar a obra das mulheres como um tecido contínuo que permitisse estabelecer uma temática comum.

${ }^{43}$ Sob o pretexto de separar temas exclusivamente femininos, não corramos o risco de nos limitar e de levar a mulher a uma fisiologia, o que seria um meio de continuar a fechá-la e a limitá-la.
} 
também interferiu e a fez demorar ainda mais para conseguir romper seu silêncio e vencer a dificuldade da palavra que sempre figurou para ela no terreno da interdição.

Era preciso criar a possibilidade da solidão que permitisse a ela se refugiar na escrita, romper com a condição que a impedia do direito de interiorizar-se, já que o compartimento da casa dedicado à reflexão, o escritório, era área limitada apenas aos homens. Para poder integrar-se à vida intelectual, a mulher tinha que romper com a restrita conduta familiar, pois o tempo de filhos e marido não poderia dividir-se com arte ou outras reflexões perigosas.

O ato de escrever era já uma espécie de fuga, de transgressão para além dos muros do patriarcalismo. O desejo de ver-se em uma condição mais livre é um dos caminhos que levará a escritura de autoria feminina a explicar sua dualidade revelada principalmente na personagem sempre dividida entre o que espera alcançar e aquilo que lhe permite a organização da família: a procriação.

Ao decidir romper com a própria insatisfação, essa mulher-escritora lança mão do silêncio e de um certo isolamento que permita a ela mergulhar em si mesma, em uma zona de silêncio que, segundo Didier, permite-lhe a escrita. Por outro lado, calarse leva à introspecção atribuindo a algumas mulheres a característica de estranha, incômoda e incompreendida, vivendo em uma condição limitadora.

A necessidade de silêncio e a tentativa de refugiar-se no próprio interior, tão presentes no cotidiano da mulher, fortaleceu ainda mais a tendência intimista que marca a escritura de autoria feminina. Há em tal processo muitas vezes o desejo da autora em recriar na ficção momentos ou aspectos que lhe são marcantes. Benilde Justo Caniato relaciona ainda as características da escritura intimista a certa necessidade de busca do próprio romancista: "interessa-lhe não simplesmente narrar aquilo que se passou, mas reviver alguns instantes por ele selecionados" ${ }^{\prime 4}$.

É na busca de compreender os momentos vividos, e mergulhar em si mesma, que se justifica a importância que possui em tal literatura a figura da mulher, tornando-se mais relevante o ser do que o fazer. No conflito eu/mundo a subjetivação substitui a ação, daí então as personagens recolherem-se em um mundo de ausências, restando-lhes apenas o confinamento na solidão e no tempo do já vivido:

\footnotetext{
${ }^{44}$ CANIATO, Benilde Justo. A solidão de mulheres a sós. São Paulo, Centro de Estudos Portugueses da Faculdade de Filosofia, Letras e Ciências Humanas da USP, 1996, p. 14.
} 
"A vida autêntica será o regresso ao passado, pois ali poderão descobrir o sentido mais profundo do existir" (CANIATO, 1996, p. 16). 


\section{Um momento em dois retratos: Brasil \& Portugal}

Ao aproximarmos as literaturas do Brasil e de Portugal temos como passo primeiro sinalizar o momento em que essa aproximação se dará: o século $X X$, mais especificamente os anos 60 , momento da publicação dos dois volumes de contos que serão estudados. Como já citado no capítulo anterior, o papel ocupado pela mulher, que encontra eco na ficção de autoria feminina, tem suas raízes no contexto históricosocial formador das sociedades nas quais é construída tal ficção. No caso do presente trabalho, temos as sociedades do Brasil e de Portugal, das quais faremos uma breve abordagem.

Desde os anos de 1930, o Brasil teve os olhos mais voltados para si mesmo, fator que certamente nas artes se iniciou anos antes com a Semana de Artes Modernas de 1922. Os escritores da chamada literatura de 30 contribuíram para que a linguagem e as diferenças culturais do país fossem descobertas pelos brasileiros e, nas palavras de Benjamin Abdala Júnior, a produção dessa época foi responsável também para elevar certos aspectos já apresentados pelo movimento de 1922: "A problematização de uma linguagem brasileira, iniciada no Modernismo de 22, amadureceu neste período histórico, para emergir com grande criatividade em meados da década de $40 " 45$.

Os anos de 1950 decorreram marcados pela busca do "desenvolvimentismo", passando o nacionalismo a ser mais difundido no Brasil, mas ainda assim o país era tratado com desconfiança no exterior; a afirmação do país na política e na cultura era vista com descrédito pelo próprio brasileiro. Nesse contexto se estabelece a nova capital do país, Brasília, uma cidade planejada e admirada por todos pela particular arquitetura de Oscar Niemeyer e Lucio Costa. Assim chegam os anos 60, cheios de expectativas e marchando para a modernização, aliados às novas esperanças chegaram também os movimentos de reivindicações sociais: "Cresciam, entretanto, as tensões sociais: setores populares reivindicavam os benefícios da industrialização. $\mathrm{E}$ a arte brasileira também participava desse processo" (ABDALA JR, 2004, p. 197).

\footnotetext{
${ }^{45}$ ABDALA JR, Benjamin. Tempos da literatura brasileira. São Paulo, Ática, 2004, p.196.
} 
A cultura e arte brasileiras construíam um novo quadro, inovações musicais e ousadias de composição elevavam a categoria de nossa música: o Tropicalismo foi o grande exemplo de retomada da postura revolucionária de 22. $\mathrm{Na}$ literatura as produções se voltavam para o cenário social e político do país, Quarup, de Antonio Callado, foi considerado por críticos como Alfredo Bosi "um dos romances mais representativos do Brasil pós-64", mostrando com profundidade o novo caminho do romance político, "com ênfase no compromisso individual perante a sociedade" 4 .

No cenário sócio-político as minorias começavam a organizar movimentos de manifestação, para exigirem seus direitos, assim o país vive em 68 um ano também de protestos e lutas das classes menos favorecidas, e de forte reação da classe artística brasileira e, como não podia deixar de ser, houve reação do governo militar: "Em 1968, essa contestação ampliou-se para outros setores sociais, decretou-se então o Ato Institucional n. ${ }^{\circ} 5$ (...) Irromperam, de um lado, a guerrilha, e, de outro, a repressão e a censura" (ABDALA JR; 2004, p. 198).

Certamente que essas mudanças no panorama social e político do país logo influenciaram na produção literária; forma e conteúdo se modificavam, mostrando um retrato inovador na estrutura do que era produzido na época. O escritor tornou-se mais reflexivo e introspectivo e se apropriou da linguagem com mais intimidade e ousadia, e essa linguagem, que já vinha se modificando desde a época dos modernistas, refletiu a nova postura, em desenvolvimento desde a Semana de 1922, nas palavras de Bosi:

O quadro pressupõe que a literatura escrita de 1930 para cá forme um todo cultural vivo e interligado, não obstante as fraturas de poética ocorridas depois da II guerra. Daí ser precoce dar como passados e ultrapassados o romance social e intimista dos anos de 30 e 40; de resto, ambos têm sabido refazer-se paralelamente às experiências de vanguarda. (BOSI; 1970, p. 395)

Dentre as grandes mudanças que aconteceram no país na década de 1960 não podíamos deixar de citar a importância da inauguração de Brasília, 1959, e o grande acontecimento político que foi desde sua construção. O país adentra no decênio seguinte com a idéia de urbanização gerada pela busca da modernização,

\footnotetext{
${ }^{46}$ BOSI, Alfredo. "O modernismo e o Brasil depois de 30”. In História concisa da literatura brasileira. São Paulo: Cultrix, 1970 p. 421.
} 
que culminou no deslumbre causado pela nova capital política que havia sido construída em cima do nada, de uma devastação do cerrado, um urbanismo impossível aos olhos de alguns. Mas que se tornou real na cidade planejada e construída nos moldes da política e fruto das empolgadas promessas de campanha de Juscelino Kubitschek. A própria Clarice Lispector escreveu sobre a cidade em decorrência de sua estada lá em meados dos anos de 1970:

Brasília é construída na linha do horizonte - Brasília é artificial. Tão artificial como deveria ser o mundo quando foi criado (...) Os dois arquitetos não pensaram em construir beleza, seria fácil; eles ergueram o espanto deles e deixaram o espanto inexplicado. A criação não é uma compreensão, é um novo mistério. (LISPECTOR, 1994, p. 313)

O quadro do país durante os decênios de 60 e 70 construiu-se não diferente do que se passava em outros países da América Latina e em muitos países da Europa. A política se construiu em meio ao golpe militar, seguido pela longa ditadura, e a arte tendo que se confrontar com a censura e as lutas sociais, que uniam trabalhadores, estudantes e artistas, fizeram dessa uma época fervilhante e de protestos. Tal panorama político-social nos aproximou de Portugal que, mesmo em outro continente, vivia situações bem parecidas, como veremos mais à frente. O Brasil acompanhava o contexto mundial, pois era época de reivindicações e de dar voz aos grupos desfavorecidos mundo afora, como defende Alfredo Bosi:

Mas esses anos de arbítrio, que partilhamos com outros povos da América Latina, não se podem considerar tempos de isolamento cultural; ao contrário, coincidem com a explosão de maio de 68 na França e com os seus vários desdobramentos que atingiram em cheio formas de conduta individual e modos de expressão entre as gerações que sofreram o seu impacto. (BOSI; 1970: 435)

Os anos de 1960 talvez tenham sido uma das épocas em que mais se aliou o pensamento sócio-político ao cultural e artístico, como sustenta grande parte da crítica brasileira. As tensões ocorridas entre artistas e autoridades políticas não minaram 0 desenvolvimento cultural e a criação artística da época, aliás, contrariamente, viveu-se um período de aceleração. A música e a literatura, para não nos estendermos a outras 
artes, viveram tempos de grandes criações, a repressão era usada como matéria de criatividade musical; além de motivo da busca de si mesmo no tocante ao literário.

O Tropicalismo teve destaque como motivador da resistência cultural no final dos anos 60, além de sua importância como movimento artístico e inovador, agregando diferentes artistas na proposta revolucionária que trazia. Vale a pena lembrar que o movimento tropicalista tornou-se indissociável da formação política que vinha acontecendo no país desde o decênio anterior, podendo ser considerado uma espécie de resultado de tal política. Reafirmando assim o que já dissemos sobre a forte ligação entre as mudanças políticas e os movimentos culturais, sobretudo de uma cultura que reclamava seu lugar.

O quadro da época favorece uma escrita mais voltada para o eu, o que favorece a literatura intimista que surge os anos 40 avança e chega à década de 1960 ainda mais fortalecida devido às teorias do pós-guerra, entre elas a do existencialismo, que acentuou o olhar melancólico em relação ao futuro. Como resposta a tal momento temos a necessidade de introspecção do autor; na parte estrutural aspectos como o monólogo interior e o discurso indireto livre vão fazer parte da linguagem e contribuir para a tensão no embate eu/mundo. Neste contexto estão, entre outros, escritores como Osman Lins, Autran Dourado, e na produção de autoria feminina ocupam importante lugar as obras de Lygia Fagundes Telles, Nélida Piñon e Clarice Lispector.

Assim como o Brasil, Portugal também vive um período de grandes mudanças vindas com o século $X X$. As transformações políticas e econômicas que aconteciam desde o final do século XIX vão tomar proporções que influenciarão de diferentes maneiras a vida dos portugueses, reforçando a crise entre os que lutavam pela renovação do país e os que pretendiam conservar as tradições.

O final da década de 1920 se caracteriza por um grande enfraquecimento da república, com crises econômicas, greves e protestos da classe trabalhadora que vão marcar o período. Os confrontos entre trabalhadores e forças do Governo foram aos poucos alarmando todas as camadas sociais e instaurando o clima de revolução. $O$ quadro político que se apresentava contribuía para o enfraquecimento ainda maior do Partido Democrata que estava no poder havia alguns meses, fazendo com que oposição e direita se mantivessem de acordo pela revolução. Em tal contexto teve 
início em 1926 a ditadura militar que duraria até 1939 e seria julgada de maneira diferente pelas camadas sociais portuguesas:

Para uns foi um período totalmente negativo, que substituiu a autoridade pela demagogia, desorganizou o aparelho do Estado, tornando-o incapaz de resolver problemas reais, empobreceu o País, retardou o progresso económico (...) Para outros, foi uma época de agitação fecunda e criadora que fez a primeira experiência de governação democrática ${ }^{47}$.

A ditadura militar seguiu-se com crise no setor financeiro, com os gastos dos militares tomarndo proporções alarmantes e a tentativa de pedir ajuda a outros países desmoronou embaixo das ferrenhas condições impostas. Foi neste momento de conturbações econômicas que Antonio de Oliveira Salazar chegou ao poder para equilibrar as finanças e seu nome cresceu de tal maneira que em pouco tempo se tornaria o líder do Estado Novo instaurado em 1933. As tantas mudanças políticas fizeram com que Portugal chegasse à década de $1960 \mathrm{com}$ a tarefa de reestruturar sua economia. No entanto a construção de grandes prédios públicos, e os planos econômicos contribuíam para um novo quadro do país.

Havia certo crescimento dos números da economia, o país evoluía em relação aos períodos econômicos anteriores, mas ainda apresentava certo atraso em relação aos países desenvolvidos. Tal aspecto era notado pelo povo português e também pelos países da Europa, o que fazia com que os resultados do crescimento fossem constantemente analisados segundo essas duas posições:

Os resultados conseguidos foram julgados segundo ambas essas perspectivas: os que compararam com os anteriores estádios da evolução nacional consideraram-nos reveladores de um progresso enérgico; os que os compararam com os valores europeus viram neles a indicação de um atraso crescente. (SARAIVA; 1996, p. 362).

A economia continuava marcada pela posse e exploração da terra, mantendo o status de país agrícola, e ainda que houvesse um interesse maior no

\footnotetext{
${ }^{47}$ SARAIVA, José Hermano. História concisa de Portugal. Portugal: Europa-América, 1996, p. 355.
} 
desenvolvimento industrial, não havia planos ou estratégias que fomentassem a formação técnica para a indústria privada ou o incentivo para que esta se estabelecesse na sociedade de então. Ainda assim os anos de 1950 foram marcados pelo desenvolvimento dos números industriais muito mais do que os agrícolas.

Continuavam os problemas como diferenças de salário e o atraso "campocidade" herdado de anos anteriores, o que daria origem ao longo período de intensa emigração ocorrido entre as décadas de 1960 e 1970. Os portugueses buscavam em outros países da Europa, principalmente a França, mercados de trabalho mais promissores e nos quais pudessem ser bem remunerados, exercendo funções parecidas com as que tinham em seu país. Tal movimento resultou na desertificação de algumas áreas agrícolas, principalmente as mais pobres; mas por outro lado desencadeou a alta nos salários pela escassez de mão de obra.

A intensa emigração trouxe também o descrédito no país. Muitos portugueses se sentiam angustiados pela situação de incerteza que tinham que enfrentar ao deixar o país. O período de incerteza vai refletir-se não só na sociedade, mas na literatura e nas artes em geral, como não havia mais lugar para os sonhos românticos, o momento pedia uma literatura que traduzisse a consciência do homem moderno, angustiado e em crise existencial, num cenário de tensão que antecederia a última revolução.

Ao lado de toda a insatisfação com a economia e a política do país surgiram em 1961 os movimentos de guerrilha das colônias africanas, o que logo se tornou um tema importante no debate dos opositores ao regime de Salazar: "O protesto contra a guerra tornou-se então o tema dominante da oposição ao regime, na qual passaram a ter parte muito ativa as camadas jovens, em especial os estudantes universitários" (SARAIVA, 1996, p. 365). É o momento de a sociedade estudantil unir-se em movimentos que exigiam as mudanças necessárias.

$\mathrm{Na}$ literatura as vozes representantes das minorias começavam a aparecer e o desejo de reivindicação movia a classe artística e as pessoas em geral. Era forte a presença da geração influenciada pelo Existencialismo francês, que encontrou representação na obra de Vergílio Ferreira. É neste cenário de transformações que surge um livro marcante para os anos de 1970, Novas cartas portuguesas (1972), obra 
escrita por três autoras e que marcou a literatura da época, tornando-se uma das publicações mais importantes no domínio da escritura de autoria feminina.

Construído com uma linguagem além de seu tempo e ousando tratar de temas tabus para o universo feminino, o livro conseguiu retratar mulheres representantes de vários tipos sociais e seus diferentes conflitos, que se tornaram assuntos das diversas cartas, textos, confissões e declarações de personagens que denunciavam a condição submissa da mulher. Por se tratar de uma obra inovadora tanto em sua estrutura como em seu conteúdo, o caráter transgressor que havia em suas páginas foi considerado inadmissível pela sociedade da época, tornando-se objeto de censura. Como nos explica Maria Graciete Besse:

acusadas de pornografia e ultraje à moral pública, Maria Isabel Barreno, Maria Teresa Horta e Maria Velho da Costa viram o seu livro retirado do mercado e descobriram-se a braços com um processo judicial a que só a pressão dos movimentos feministas internacionais e sobretudo a Revolução dos Cravos permitiram pôr termo ${ }^{48}$.

Com um jogo de pluralidades nos vários tipos sociais representados, os depoimentos e cartas trazem um amplo retrato da opressão feminina, expondo também a maneira como a mulher é definida segundo o pensamento patriarcal, o qual a confinou a uma condição marginal e destinada à domesticação e à criação de filhos. Encontramos retratados nos textos todos os estereótipos femininos, desenvolvidos pela sociedade, desde os mais tradicionais àqueles advindos sob o estigma da vida moderna, como nos explica Maria Graciete Besse: "a mulher solteira e desprezada, que trabalha para ganhar um salário de miséria, ou ainda a mulher transformada em objeto de consumo vítima do seu destino biológico" (BESSE, 2006, p. 17).

Visto pela crítica como obra fundamental em termos estruturais, por sua forma inovadora de condensar vários tipos de texto, Novas cartas portuguesas também se tornou o marco para uma nova escrita feminina em Portugal. Primeiramente, por dialogar com os temas sociais que afligiam a mulher da época, ao mesmo tempo em que falava de amor, tema recorrente na escritura de autoria feminina. Depois, por usar a forma epistolar, numa voz que denuncia, e que une universos diferentes.

\footnotetext{
${ }^{48}$ BESSE, Maria Graciete. “As Novas Cartas Portuguesas e a contestação do poder patriarcal”. In LatitudesCahiers Lusophones n. 26 - abril 2006, Paris-France, p. 16.
} 
Nas tantas situações limites que mostram todo o preconceito do qual a mulher era vítima, as autoras transgridem com a passividade sob a qual o comportamento feminino estava sustentado. O protesto que emana nas vozes das várias personagens do livro chama atenção para um desejo de mudança e uma necessidade de buscá-la, dando ao tema da obra também um caráter social e político de grande importância para a época, e que se torna atual quando pensamos na condição da mulher:

E jamais, pois, nenhuma de nós três: mulher, se entregará sem dano de si própria e de outrem. Ramificação oculta que transportamos na voragem de nos sabermos, de nos descobrirmos, na viagem que premeditadamente empreendemos através de nós próprias na procura ou na entrega. (BARRENO, HORTA, COSTA; 1974, p. 12)

O discurso do livro, seu caráter inovador, as diferentes classes femininas representadas, a exposição crua dos desígnios da sociedade patriarcal, dentre outras características, contribuíram para que se tornasse obra de referência nos estudos que se ocupam do feminino e da condição da mulher, universalizando-se também como obra inovadora desde a sua estrutura, composta de vários tipos diferentes de textos, até a sua autoria com uma tríade de autoras:

O discurso de Novas cartas portuguesas corresponde assim a um exercício entendido como instrumento político, como revisitação da ordem simbólica que governa a sociedade, através da noção de "resistência feminina" que aponta para duas atitudes fundamentais (...): uma forte mobilização no sentido de conquistar direitos cívicos e liberdade de expressão; e uma escolha identitária que tenta promover uma relação feminina com o mundo, através do exercício de uma escrita ligada à condição das mulheres. (BESSE; 2006: 19)

As opiniões divididas, o descrédito no regime vigente e os conflitos sócioeconômicos tornaram inevitável a revolução que acordou o país em 25 de abril de 1974. Com a chegada da revolução, o povo nas ruas e a esperança de um país melhor, conseguiram combater boa parte do espírito de angústia que antes pairava sobre Portugal. Certamente não foi o fim das contradições sócio-políticas nem dos 
problemas econômicos, mas um avanço muito importante rumo à liberdade na história daquele país que saía de quatro décadas de ditadura:

E, enfim, todos se sentiam empolgados pelo magnetismo da palavra Liberdade, embora o conteúdo do termo pudesse ser muito diferente para uns e para outros. E pode dizer-se que esses três valores mudança, paz, liberdade - eram festejados por todos. (SARAIVA; 1996, p. 366)

Como foi possível ver no breve panorama da situação das sociedades brasileira e portuguesa durante os anos de 1960, e alguns anos antes, o período era de mudança nos dois países. Tanto a política, a economia, como as artes em geral se voltavam para o novo e necessitavam promover esse novo, fosse nas revoluções, ou nos movimentos de protesto. Ou ainda nos recursos artísticos que pudessem chamar atenção para uma denúncia ou um desejo de ruptura. As duas sociedades, ainda que separadas pelo atlântico, encontram-se muito próximas. É o que vemos também no que diz respeito à inovação das produções literárias, tanto as que se desenvolveram na época como as que surgiram posteriormente são literaturas que caminham em direções parecidas.

O século $X X$ foi um momento também de troca intelectual entre os dois países. A partir de meados do século a literatura da ex-colônia começou a ganhar mais lugar nas terras portuguesas, com os autores brasileiros passando a ser mais visitados pelos leitores lusitanos. Enquanto aqui se vivia sob as tensões do período militar, lá a insatisfação preparava a revolução. Portanto os momentos são próximos, e os olhares de Portugal em relação ao Brasil são novos, o que permite uma certa inversão e receptividade de nossa criação artística:

$\mathrm{Na}$ verdade, só o século passado assistiu (séc. $\mathrm{XX}$ ), embora excepcionalmente, à inversão do clássico fluxo cultural de Portugal para o Brasil. Terra de acolhimento e não de exílio ${ }^{49}$.

\footnotetext{
${ }^{49}$ LOURENÇO, Eduardo. "Pequena diáspora lusitana”. In Incertas relações, Org. Benjamin Abdala Jr. São Paulo: Editora Senac, 2003, p. 39.
} 
É preciso lembrar que as relações entre os dois países se tornaram mais estreitas nos anos de 1950 com a assinatura do Tratado de 1953 que incentivava a formação de uma comunidade luso-brasileira:

unida, na substância, da equiparação de portugueses e brasileiros; da livre circulação de brasileiros e portugueses nos respectivos países; e da aplicabilidade do tratamento da nação mais favorecida aos cidadãos de ambos os países ${ }^{50}$.

Tal incentivo aumentou também a troca política, cultural e artística entre as duas sociedades, tendo como ponto marcante o grande número de intelectuais portugueses que buscaram no Brasil uma saída para o descontentamento com o salazarismo. Entre eles Jayme Cortesão, Adolfo Casais Monteiro, Eduardo Lourenço, Victor Ramos, Jorge de Sena, Miguel Urbano Rodrigues ${ }^{51}$. E tantos outros que ajudaram a compor a "missão intelectual" que também contribuiu para aproximar nossas literaturas.

No campo da política também temos períodos de paralelismos interessantes de serem ressaltados, como o Estado Novo instituído por Salazar e o Estado Novo do período de Vargas. Em Portugal, o novo regime permaneceu por longos quarenta e um anos, 1933 a 1974, enquanto que no Brasil o Estado Novo duraria apenas de 1937 a 1945. As idéias que moviam o golpe dos dois lados do Atlântico eram parecidas, instaurando-se um clima de apreensão e perseguição política a muitos intelectuais, resultando em longo período de exílio que marcou os dois países.

Vemos então que as relações políticas, culturais e artísticas entre Brasil e Portugal se aproximaram ainda mais durante o séc. $X X$, guardadas as devidas diferenças, representando-se na troca e na complementação entre as literaturas daqui e de lá, que têm sempre se encontrado em pontos importantes estruturais ou de conteúdo. O resultando mostra-se na continuidade e renovação dos estudos comparativos entre os dois países, que conseguem sempre se justificar em si

\footnotetext{
${ }^{50}$ LAFER, Celso. "Relações Brasil-Portugal: passado, presente, futuro". In Incertas relações, Org. Benjamin Abdala Jr. São Paulo: Editora Senac, 2003, p. 82.

${ }^{51} \mathrm{O}$ jornalista era irmão do escritor Urbano Tavares Rodrigues, marido de Maria Judite de Carvalho, e trocou correspondência com o casal durante todo o seu período no Brasil, voltando a Portugal após a revolução de 25 de abril.
} 
mesmos, sejam eles baseados em convergências ou divergências, podendo estas serem históricas, culturais ou simplesmente temáticas.

\subsection{Duas escritoras: tramas, traços e caminhos}

A covardia nos mata. Pois há aqueles para os quais a prisão é a segurança, as barras um apoio para as mãos. Então reconheço que conheço poucos homens livres.

\section{Clarice Lispector}

Talvez de futuro as pessoas possam ser aquilo que valem (...) E que um homem, seja qual for o seu valor pessoal, não seja sempre mais importante do que uma mulher.

Maria Judite de Carvalho

Não é objetivo das páginas a seguir prender-se muito em dados biográficos de uma ou outra autora, porém acreditamos juntamente com uma parte dos críticos, haver certa relação entre o autor e sua obra ${ }^{52}$. Tal característica deve ser levada ainda mais em consideração quando temos diante de nós Clarice e Maria Judite, escritoras que contribuíram em vários jornais e revistas de seus respectivos países. Este, entre outros, é fato importante que aproxima a trajetória das duas autoras e que não pode deixar de ser mencionado.

Ressaltamos também que, neste momento do trabalho, nos preocuparemos mais com aspectos importantes no que diz respeito à criação literária das duas escritoras, e de como através das obras puderam se destacar nas letras brasileiras e portuguesas. Na crítica das autoras e na aproximação delas com outras escritoras do mesmo período, poderemos comprovar a particularidade que cada uma atingiu através de seus romances, novelas, contos e crônicas, dentro e fora de seus países.

No texto que introduz nosso estudo, citamos a importância de alguns dos pontos que aproximam e justificam uma comparação entre Clarice Lispector e Maria

52 A esse respeito ver NOLASCO, Edgar Cézar. Clarice Lispector: nas entrelinhas da escritura. São Paulo: AnnaBlumme Editora, 2001. 
Judite de Carvalho. Já se sabe, por alguns dos passos percorridos neste trabalho, que há uma aproximação entre suas escrituras em diversos pontos, principalmente no que se refere à personagem - alvo principal de nossas análises. Porém em meio a essas aproximações, constataremos também que as escritoras seguem caminhos diferentes entre si e que possuem, cada uma, seu grau de importância e de particularidade.

No que diz respeito à vida das autoras, o quadro não é muito diferente, em suas trajetórias encontramos vários momentos de convergências, seja pela época das publicações, seja por circunstâncias da vida que fizeram com que as duas escritoras se deslocassem do país de nascença, fator esse que as mantém ainda mais inseridas em uma literatura sem fronteiras. No presente capítulo será desenvolvido o eixo entre aproximações e distâncias, os vestígios das escrituras das duas autoras, os detalhes das trajetórias de vida e as particularidades que fizeram com que a literatura que produziram se destacasse. Seja na linguagem particular ou na maneira sutil, porém intensa, com que retrataram as sociedades brasileira e portuguesa da segunda metade do século $X X$, as suas narrativas são sempre caminhos a descobrir, numa circularidade que envolve uma eterna busca.

Sabemos que um estudo comparativo se dá pelo curso das semelhanças e divergências, portanto os pontos que serão expostos a seguir têm o intuito de situar as autoras dentro de sua época e sociedades respectivas, mas também de dizer porque é importante o confronto das obras dessas duas grandes escritoras.

\subsection{Discreto infinito: a escrita de Clarice Lispector}

A escrita de Clarice Lispector desde sua estréia foi considerada como inovadora no campo da linguagem, inaugurando uma nova maneira de descrever a relação sujeito/objeto/mundo, o que se traduz na forma de abordagem da realidade a sua volta. Nesta realidade redimensionada a personagem cresce em envolvimento com a palavra poética a partir do contato com "uma verdade que despoja o eu das ilusões cotidianas e o entrega a um novo sentido da realidade" (BOSI; 1970, p. 425). 
Assim, a narrativa de Clarice apresenta-se de maneira introspectiva, porém sem subtrair o olhar agudo que a autora direciona à sociedade de seu tempo.

Mesmo não se tratando de uma escritora claramente engajada, sabemos que a narrativa clariceana jamais esteve alienada ou distante das mudanças de seu tempo. Através de suas personagens, sempre inquietas por um fato ou objeto do cotidiano, é possível observarmos essa realidade concreta. Os efeitos das difíceis relações sociais e o peso do cotidiano se apresentam em grande parte de suas histórias; os fios que tecem sua obra unem forma e conteúdo para construir o retrato de uma desorganização para a qual a única solução encontra-se no interior dos seres que ela constrói:

É admirável sua consciência técnica adequando forma e conteúdo. Por exemplo, dissocia as unidades narrativas para mostrar a falta de ligações mais profundas na sociedade. Organiza a narrativa em ritmo lento, para contrastar com o movimento da vida nas grandes cidades. Filtra todos os fatos através de uma consciência que se isola do conjunto - eis aí a solidão do homem moderno. (ABDALA JR, 2004, p. 273).

Há em algumas crônicas ou em fragmentos de textos clariceanos traços declarados de um engajamento que contraria muitas palavras da crítica. Na crônica intitulada "Carta ao Ministro da Educação", publicada no Jornal do Brasil em 1968, a ficcionista desabafa seu protesto indignado contra os problemas de verba para a educação e da exclusão de estudantes:

Senhor ministro ou senhor presidente: "excedentes" num país que ainda está em construção?! E que precisa com urgência de homens e mulheres que o construam? Só deixar entrar nas Faculdades os que tirarem melhores notas é fugir completamente ao problema. (LISPECTOR, 1994, p. 73)

Segundo Jaime Ginzburg, a crônica da autora desafia os critérios de avaliação de um texto literário por estar entre a crônica, a carta, o testemunho. 0 crítico afirma ser este um texto que "enriquece de modo decisivo o amplo debate sobre 
as relações entre literatura e história recente no Brasil"53. Sendo também um texto revelador de uma Clarice não apenas preocupada com os problemas sociais, mas que protesta e desafia as autoridades em tempos de repressão.

É também neste clima de protesto que vemos Ana paralisar o olhar diante do cego ignorando o movimento no meio da tarde carioca, assim como tantas outras personagens de Lispector que por uma reflexão repentina são retiradas do turbilhão da vida cotidiana de uma grande cidade. É assim que vemos a protagonista de "A bela e a fera ou a ferida grande demais", estagnar-se em plena esquina de um bairro de classe alta do Rio de Janeiro e o motivo é a profunda ferida na perna de um mendigo. O choque de estar diante do mundo em carne viva contrasta com o brilho nos cabelos que ela acabara de fabricar em um salão de beleza: "Ela - os outros. Mas a morte não nos separa, pensou de repente e seu rosto tomou o ar de uma máscara de beleza e não beleza de gente: sua cara por um momento se endureceu" (LISPECTOR, 1999, p. 98).

O cotidiano, as relações, as mudanças sociais e a maneira como interferem na existência das personagens são temas freqüentes nos enredos clariceanos. Daí ser possível sustentar com Abdala Jr que "seus livros são altamente comprometidos com o homem e com a realidade dele" (ABDALA JR; 2004, p. 273). Por trás dos momentos de choque, ou epifania ${ }^{54}$, já tão abordada pela crítica, estão fatores sociais, como vimos acima, que cercam as personagens de Lispector, seja um casamento no qual depositam sua vida, uma relação de submissão com o outro, ou ainda seres vivendo em total superficialidade, como no caso da mulher de classe alta do conto acima citado, que percebeu que a riqueza tinha lhe custado a consciência de si e do mundo a sua volta.

Em suas crônicas que integravam as páginas femininas ${ }^{55}$ de alguns jornais cariocas da década de 1960, encontramos textos persuasivos através dos quais a ficcionista tenta convencer suas leitoras de que é preciso cultivar algo mais para além

\footnotetext{
${ }^{53}$ GINZBURG, Jaime. “A literatura contra o Estado em 1968: política e exclusão em Clarice Lispector”. In Revista Atlântica. Publicação da Área de Estudos Comparados de Literaturas de Língua Portuguesa, Departamento de Letras Clássicas e Vernáculas da Universidade de São Paulo, n. 12, São Paulo, 2007.

${ }^{54}$ SÁ, Olga de. A escritura de Clarice Lispector. Petrópolis: Editora Vozes, 1993.

${ }^{55}$ A esse respeito consultar NUNES, Aparecida Maria. Clarice Lispector jornalista: páginas femininas \& outras páginas. São Paulo: Editora Senac, 2006.
} 
da aparência. Quanto mais a mulher conseguir instruir-se mais vai se tornar atraente e cobiçada pelos homens, e tudo isso sem perder o charme que é, segundo Clarice, o toque a mais para o feminino:

Ela estuda, ela lê, ela é moderna e interessante sem perder seus atributos de mulher, de esposa e de mãe. (...) Ela cultiva, especialmente, sua capacidade de ser compreensiva e humana. Tem coração. Despojase do sentimentalismo barato e inútil, e aplica sabiamente a sua bondade e a sua ternura. É mulher. (LISPECTOR, 2006, p. 18)

Em seu depoimento sobre os anos de amizade com a ficcionista, Olga Borelli descreve o universo clariceano sob vários aspectos, indo desde o dia a dia comum até a relação de Lispector com a escrita. Sobre o engajamento com questões sociais, Borelli diz ser característica marcante da autora a observação e o choque diante dos fatos sociais que ela encontrava nas ruas do Rio de Janeiro, ou no mundo afora, e que seu desejo era interferir ou tentar resolvê-los:

A verdade, porém é que tudo o que se refere à questão social sempre esteve presente em sua vida. Ela jamais conseguiu apagar da memória a imagem da miséria nordestina, a pobreza do Recife, principalmente a que até hoje se concentra nos mocambos dos mangues recifenses. ${ }^{56} \mathrm{p}$. 53.

Mesmo existindo em sua obra referências à sociedade de sua época, poucos são os críticos que se preocupam com a importância de levar em consideração os conflitos de ordem social, sobretudo no que se refere às personagens femininas de Lispector. Entre esse pequeno número está Ligia Chiappini ${ }^{57}$, que em seu ensaio ressalta um dado importante nos enredos clariceanos: o contato das personagens com o meio exterior ao ambiente doméstico, representado pela rua, e ainda a importância de focalizar a condição feminina na obra da autora, enfatizando também as relações sociais. É na rua que melhor podemos identificar a posição social da mulher e, partindo

\footnotetext{
${ }^{56}$ BORELLI, Olga. Clarice Lispector: Esboço para um Possível Retrato. Rio de janeiro, Nova Fronteira, 1981, p. 53.

${ }^{57}$ LEITE, Ligia C.M. "Pelas ruas da cidade uma mulher precisa andar: Leitura de Clarice Lispector". In Literatura e Sociedade, Revista do Departamento de Teoria Literária e Literatura Comparada da FFLCH-USP, São Paulo, 1996, n. 1.
} 
daí, ter um ponto inicial para entendermos questões de ordem existencial no universo clariceano.

Segundo Chiappini, as personagens clariceanas seguem uma trajetória de choque, busca e auto-reconhecimento que as faz aventurarem-se pelas ruas do Rio de Janeiro, na tentativa de fazer parte de um meio do qual se acostumaram a serem excluídas. No reconhecimento da vida em sociedade, as personagens confrontam-se com o perigo das relações sociais para fora da proteção do lar, então o choque é ainda mais intenso, pois Ihes falta o chão, e a insegurança torna a queda inevitável.

As abordagens da ensaísta nos remetem também a um outro tema muito presente na criação de Lispector: o papel social da mulher, sua condição muitas vezes submissa a um casamento, em confronto com o desejo de libertar-se. Tal conflito gera um fluxo de pensamentos expressos na verborragia que particulariza também a linguagem da autora. A aproximação entre o social, o existencial e o lingüístico tornase importante para analisar os enredos da autora: "Continua-se estabelecendo uma separação, a meu ver forçada, entre o social, o existencial, o lingüístico e o feminino, que não me parece sustentar-se pela análise da obra" (LEITE, 1996, p. 61).

Em contos como "A bela e a fera ou a ferida grande demais" encontramos a séria denúncia da miséria e da desigualdade social. Ao confrontar a mulher de um banqueiro com um mendigo na cidade do Rio de Janeiro, a autora questiona vários aspectos sociais, entre eles a incapacidade da mulher de lidar com as diferenças e a realidade do mundo ao seu redor. Ao observar uma grande ferida aberta na perna do mendigo, ela se sente obrigada a abandonar o mundo de fantasias e futilidades e a perceber que a miséria existe bem ao seu lado: "Mas a morte não nos separa, pensou de repente e seu rosto tomou ar de uma máscara de beleza e não beleza de gente: sua cara por um momento se endureceu". 58

O fato de a personagem se encontrar na rua e sozinha propicia o encontro com o mendigo e com uma realidade que ela jamais vira. Mesmo em seu estado de ingenuidade, a mulher começa a refletir e sente-se envergonhada de ter muito e ser

\footnotetext{
${ }^{58}$ LISPECTOR, Clarice. A bela e a fera. Rio de Janeiro, Rocco, 1999, p. 97. Nas citações seguintes, os contos que fazem parte de Laços de família serão citados apenas com as iniciais do título e o número de páginas, o mesmo valendo para Flores ao telefone. Citações de outros livros das autoras virão acompanhadas de referências no corpo do texto, com bibliografia completa ao final do trabalho.
} 
tão diferente do homem com a grande ferida aberta, para quem as pessoas como ela só tinham descaso a oferecer.

Este e outros enredos sustentam as colocações de Lígia Chiappini sobre a relevância dos aspectos sociais que, de uma forma ou de outra, estão presentes nos textos clariceanos. Os confrontos entre classes diferentes, ou entre pessoas de situações de vida opostas, são pontos importantes para a reflexão, além de contribuir para a construção de um novo sujeito feminino. Como nas palavras da ensaísta:

ao apanhar a mulher e os confrontos em que se envolve na cidade dividida (...) também encontra a temática social, denunciando a seu modo a exploração, a violência e a alienação que, justamente porque indissociadas da reflexão sobre a existência, nos aparecem ainda mais violentas e absurdas. (LEITE; 1996, p. 63)

As personagens em contato com o mundo apresentam uma certa miopia, como aponta Gilda de Mello e Souza, e atribuem valores e instantes diferentes às coisas, por isso estar diante do outro pode ser um momento revelador. Em comentário ao romance $A$ maçã no escuro, a crítica observa características particulares que fazem das personagens femininas de Lispector seres que por instantes possuem mundos só seus, onde tudo ocupa um novo lugar. O importante torna-se insignificante e o aparentemente simples pode ter proporções riquíssimas: "A visão que constrói é por isso uma visão de míope, e no terreno que o olhar baixo abrange, as coisas muito próximas adquirem uma luminosa nitidez de contornos" 59 .

É nesta desorganização das imagens e das coisas que a personagem feminina toma lugar em seu estado de fuga, seja para a rua ou mesmo ficando entre as paredes de uma casa. No momento em que tudo está por um fio, ou em que o tempo é um relance, Lispector constrói suas mulheres transgressoras, que andam por jardins, observam mendigos, partem em trens noturnos, mas sempre voltam e conseguem reintegrar-se à vida de antes e torná-la possível, mesmo que elas jamais voltem a ser as mesmas.

A possibilidade de retorno será uma característica das personagens clariceanas que vai distingui-las daquelas construídas no universo juditiano. Tal

\footnotetext{
${ }^{59}$ SOUZA, Gilda de M. "O vertiginoso relance”, em Exercícios de leitura. São Paulo, Duas cidades, 1980, p. 79.
} 
característica explica a questão do suicídio ser mais freqüente nas mulheres criadas pela autora portuguesa, para as quais voltar é algo impossível e o passado é sempre um acelerador da angústia e da certeza de total falência das relações pessoais. Já em Lispector essa angústia parte de uma situação banal para uma apreensão e amplificação do instante, "da apreensão do real para a apreensão das essências e do tempo" (SOUZA, 1980, p. 79). Situação que só poderá ser suportada se retomados os laços do cotidiano, como se para elas estes fossem um apaziguador do estado de alerta.

Desde a publicação de Perto do coração selvagem, em 1943, Clarice Lispector foi vista como inovadora dentro da cena literária, autora de uma linguagem nova traduzida na "verborragia' que descreve a consciência de uma personagem convulsa diante do mundo. A cumplicidade entre lingüístico e existencial logo foi apontada como singular pela crítica na ocasião da publicação do livro:

Com efeito esse romance é uma tentativa impressionante para levar a nossa língua canhestra a domínios pouco explorados, forçando-a a adaptar-se a um pensamento cheio de mistério, para o qual sentimos que a ficção não é um exercício ou uma aventura afetiva, mas um instrumento real do espírito, capaz de nos fazer penetrar em alguns dos labirintos mais retorcidos da mente. ${ }^{60}$

A força da linguagem alia-se aos conflitos vividos pelas personagens vindas de um cotidiano aparentemente banal, que é transformado pelo choque existencial diante do mundo. Tais características contribuíram para que cada vez mais a escrita de Lispector se destacasse na literatura nacional da época. Ainda que a ficcionista tenha sido incompreendida por alguns $\operatorname{críticos}^{61}$, logo se observou no meio literário que se tratava de uma escrita de vanguarda nas letras brasileiras. Assim, o estilo clariceano foi comparado a escritores como James Joyce, Virgínia Woolf, Kathleen Mansfield e outros, como comprovamos nas palavras de Sergio Milliet:

\footnotetext{
${ }^{60}$ CANDIDO, Antonio. "No raiar de Clarice Lispector”, in Vários Escritos. São Paulo, Duas cidades, 1970, p. 127.

${ }^{61}$ Fazemos referência à crítica negativa de Álvaro Lins por ocasião da primeira edição de Perto do coração selvagem. Ver referência completa ao final do trabalho.
} 
De uma maneira que só observamos até agora em certos escritores franceses e ingleses, num Gide, num Morgan, por exemplo, o que de resto não implica em comparações deslocadas, muito embora o romance de estréia de Clarice Lispector a eleve de chofre a um plano de absoluto destaque em nossa literatura. ${ }^{62}$

Sergio Milliet analisa a protagonista Joana mostrando muito do que há de intrigante e particular em seu comportamento, desde a idade de menina até atingir a maturidade. Seu estranhamento diante dos fatos, das pessoas e do mundo acompanha as fases de sua vida sem deixá-la, e seus conflitos são descritos através de fluxos de consciência, numa experimentação de linguagem que contribui para destacar a personagem e a obra no contexto das letras brasileiras de então:

A obra de Clarice Lispector surge no nosso mundo literário como a mais séria tentativa de romance introspectivo. Pela primeira vez um autor nacional vai além, nesse campo quase virgem da nossa literatura, da simples aproximação; pela primeira vez um autor penetra até o fundo a complexidade psicológica da alma moderna, alcança em cheio o problema intelectual, vira no avesso, sem piedade nem concessões, uma vida eriçada de recalques. (MILLIET, 1981, p. 32)

Após a inquietação causada por sua estréia e a publicação de três romances, vem a público Clarice contista, com narrativas que já vinham sendo publicadas na imprensa desde 1940, mas que de início vão ser deixadas em segundo plano pela crítica. Tal situação mudará nos anos de 1960, com a publicação de Laços de família, reunião de treze contos, dos quais grande parte vinha de publicações anteriores ${ }^{63}$. Alguns críticos dizem ser a linguagem da autora mais apropriada ao romance devido a sua grandiosidade poética:

Se no seu romance já percebíamos uma tendência insopitável para a fuga ao enredo e para a transformação do diálogo em monólogo, nos contos a personalidade açambarcadora da contista se vê impedida de se expandir. Daí a impressão que temos seguidamente de uma carência

\footnotetext{
${ }^{62}$ MILLIET, Sérgio. Diário Crítico de Sérgio Milliet. 2. ed. São Paulo, Martins/Edusp, 1981, p. 30.

${ }^{63}$ Detalhes sobre a publicação, a crítica e os contos de Laços de família, encontram-se no capítulo referente às análises.
} 
qualquer a prejudicar uma expressão por tantos aspectos original. (MILLIET; 1981, p. 237)

Alguns anos mais tarde, a crítica aos contos clariceanos se tornaria mais positiva, com o argumento de que o dito "pequeno" espaço do conto não só não limitava sua criação e linguagem poética, como intensificava a relação de suas personagens com o mundo. Através das várias situações vividas por personagens de classe média é possível ver retratos da sociedade carioca e brasileira da segunda metade do século XX. As palavras de Rubem Braga por ocasião da terceira edição de Laços de família, em 1965, ressaltam o valor da contista: "sentimos com orgulho e prazer que a ucrano-pernambucana Clarice Lispector é, na verdade, uma grande contista carioca, da boa e nobre linhagem de Machado de Assis"64.

No que diz respeito à escritura de autoria feminina, Clarice se destacará pela possibilidade de juntar questionamentos a respeito da condição feminina a crises existenciais reveladoras de muitos conflitos aos quais era exposta a mulher da época. Nelly Novaes Coelho aponta, na escrita clariceana, "um tenso corpo-a-corpo com o enigma da vida, sondada até o seu cerne, para além dos limites conhecidos pela razão" 65 , e suas personagens também são inovadoras por conseguirem ir a fundo em suas reflexões existenciais e na busca por uma possível saída do conflito que se instaura em suas vidas.

A escritora soube muito bem traduzir em suas narrativas a crise "do indivíduo fragmentado" e perdido "no naufrágio" da existência, tornando-se um ser sempre em busca e, no caso das personagens femininas, essa busca terá como alvo a fuga da vida cotidiana, seja de um casamento, de um destino ou de uma condição. Sua escritura nos mostra o quadro da "existência humana entendida como busca da sua verdade autêntica, único caminho que através da palavra poderá revelar ao ser humano sua própria razão de existir" (COELHO, 1993, p. 178).

No contexto da escritura de autoria feminina da época, também se destaca a maneira como a ficcionista aborda as emoções de mulheres que, condicionadas ao

\footnotetext{
${ }^{64}$ BRAGA, Rubem. "Clarice Lispector, uma contista carioca”, in Revista Manchete, 11 de dezembro de 1965.

${ }^{65}$ COELHO, Nelly Novaes. A literatura feminina no Brasil contemporâneo. São Paulo, Siciliano, 1993 , p. 174.
} 
papel social, juntam intensidade e sutileza sobre o fio tênue das relações sociais. $E$ isso também é possível observarmos em algumas escritoras brasileiras, como Lygia Fagundes Telles ${ }^{66}$, que escreveu em época paralela à de Clarice e que teve como principal centro de sua obra os conflitos do universo feminino. A escritora retrata as inquietudes da mulher paulista de classe média a partir da segunda metade do séc. $\mathrm{XX}$.

Ao analisar a obra da escritora paulista, Nelly Novaes aponta a importância do confronto entre as personagens e a sociedade, as dificuldades das personagens femininas para esconder suas angústias atrás de um cotidiano aparentemente feliz:

Muito embora o Eu e a sociedade tenham continuado a ser as presenças de primeiro plano na teia narrativa, aos poucos, camadas mais fundas da problemática existencial vão sendo escavadas. (COELHO, 1993, p. 235).

Na escrita de Lygia Fagundes há também a busca das personagens por uma verdade que responda ou justifique o vivido, no entanto há mais familiaridade com o real e também maior aceitação da vida palpável. Tais personagens, ainda que possuam certo desconforto na relação com o outro, apresentam-se mais esperançosas diante da própria existência, e em sua busca se permitem um amor às vezes duradouro:

Quando me lembro dessa noite (e estou sempre lembrando) me vejo repartida em dois momentos: antes e depois. Antes, as pequenas palavras, os pequenos gestos, os pequenos amores culminando nesse Fernando, aventura medíocre de gozo breve e convivência comprida. ${ }^{67}$

As personagens femininas, em grande número nas obras da escritora paulista, se comparadas com outras personagens, são vítimas de solidão e crise entre o mundo objetivo e o subjetivo sejam elas mulheres casadas ou solteiras, porém há um maior esforço na tentativa de resolver tais conflitos. As personagens conseguem "escapar" ao

\footnotetext{
${ }^{66}$ Com o avanço da escrita de autoria feminina a partir dos anos 60, muitos são os nomes que surgiram na literatura, tanto no Brasil como em Portugal, no primeiro caso citaremos apenas duas escritoras Lygia Fagundes Telles e Nélida Piñon, pelo fato de abordarem temas próximos aos de Clarice Lispector e também devido a projeção de ambas no contexto literário brasileiro.

${ }^{67}$ TELLES, Lygia Fagundes. Seminário dos ratos. Rio de Janeiro: Editora Nova Fronteira, 1984, p.128.
} 
momento de solidão e se manter na estrada por onde seguiram, sem se deixar ferir pelo instante de conflito, enquanto que nos enredos clariceanos o choque é tanto e em tal intensidade que, ainda que haja uma tentativa de retorno, a chama, acesa no momento do coque, não se apaga no cotidiano e nada será como antes.

A sociedade paulista burguesa do século $X X$ é o universo retratado pela obra de Lygia Fagundes e, geralmente, o enredo é envolvido por uma atmosfera mais esperançosa em relação ao futuro. São personagens que mantêm viva a esperança de que seu mundo não está em ruínas e que por mais absurda que pareça a realidade ao seu redor, será possível sobreviver.

Certamente que ao percorrer as histórias criadas pela autora encontraremos situações diferentes que fogem às características acima expostas, como no conto " $A$ confissão de Leontina", em que a protagonista, levada pelas circunstâncias de uma vida plena de descaminhos, torna-se assassina. Mas logo vemos que também foi vítima e que matou para se defender da violência praticada contra ela:

O outro bofetão me fez bater com a cabeça na parede e a cabeça rachou feito um coco. Apertei a cabeça na mão e pensei ainda no Rogério que um dia surrou um cara só porque ele esbarrou de propósito no meu peito. Agora estava apanhando que nem a pior das vagabundas ${ }^{68}$.

Mesmo presa e com a vida repleta de infortúnios, Leontina guarda lembranças de momentos felizes e acredita que um belo homem pode livrá-la do inferno que a cerca. O otimismo resistente ao sofrimento e à capacidade de sonhar caracterizam fortemente os personagens de Lygia Fagundes, como nos explica a professora Elza Wagner Carozza: "Mesmo diante do sofrimento por amor ou na falta de alguém a quem dedicar sua emoção e seu carinho, elas não se tornam amarguradas ou descrentes do amor como o tal" 69 .

Carozza aproxima as obras de Lygia Fagundes Telles e Maria Judite de Carvalho focalizando a relação homem/mulher, ressaltando a maneira como os seres se relacionam com o meio a sua volta. Tal aproximação se justifica no plano da obra, e

\footnotetext{
${ }_{68}^{6}$. Meus contos esquecidos, antologia. Rio de Janeiro: Rocco, 2005, p. 97.

${ }_{69}$ CAROZZA, Elza Wagner. "Masculino/feminino - o eterno contraponto: uma leitura dos contos de Maria Judite de Carvalho e Lygia Fagundes Telles". In Cadernos da condição feminina, Actas II, nº 43, Lisboa, 1995, p. 246.
} 
nos remete ao artigo do professor e crítico português José Manoel Esteves, que tem como objeto algumas cartas trocadas por Maria Judite e Lygia Fagundes entre os anos de 1960 e 1990. Apesar do longo espaço de tempo, o crítico afirma haver no acervo da escritora portuguesa apenas três cartas e um cartão postal.

No conteúdo das correspondências, é possível observar a admiração que a escritora brasileira manifesta pelo livro de Maria Judite, Seta despedida, e por A hora da incerteza, livro do marido de Judite, Urbano Tavares Rodrigues: "Cette correspondance témoigne de la grande admiration et de l'affection profonde que l'auteur de Ciranda de Pedra nourrit pour l'oeuvre du couple"70. Nas demais cartas trocadas, fica evidente que as escritoras liam-se, manifestando as impressões causadas por tais leituras como mostra um trecho da carta de Lygia F. Telles à escritora portuguesa, a respeito de As palavras poupadas:

Eu o devorei em uma só noite. E logo que o fechei, eu tinha os olhos cheios de lágrimas. É que a beleza, Maria Judite, me comove tanto, e seus contos - principalmente o primeiro, que é de fato uma novela, são de uma beleza imensa. Você escreve com tal paixão, tal fervor. ${ }^{71}$

Pensamos que a proximidade entre as escritoras e a troca de reconhecimento do valor de suas obras deve-se também ao período que muito aproximou as duas literaturas, como citamos algumas páginas atrás. As personagens descritas pela escritora portuguesa causaram fascínio em Lygia F. Telles, também pelo fato de através destas se exemplificarem o momento e a condição os quais a mulher da época era obrigada a enfrentar.

Um nome que também se destaca na escritura de autoria feminina no Brasil é o de Nélida Piñon, escritora e jornalista que teve obras importantes publicadas na segunda metade do século XX; Nélida tornou-se amiga de Clarice por um longo período. Embora a primeira tenha escrito em meio às mudanças de comportamento e

\footnotetext{
${ }^{70}$ ESTEVES, José Manoel da Costa. "Vous avez pique mon imagination: Lettres de Lygia Fagundes Telles a Maria Judite de Carvalho ». In La littérature portugaise contemporaine : le plaisir du partage. Paris : L'Harmattan, 2008.

${ }^{71}$ CALHEIROS, Pedro. O imaginário de Maria Judite de Carvalho. 1921-1998, Câmara Municipal de Aveiro, 1999.
} 
das organizações sociais pelas quais passava o Rio de Janeiro da época, seus personagens nos aparecem como um pouco suspensos da realidade das ruas.

Ser e ação estão intimamente ligados na obra da autora, mas não em execuções automáticas, posto que mais importante que os atos é a consciência deles. Daí seus personagens serem de uma sensibilidade profunda e refinada. A autora se debruça com minúcia sobre a mente dos seres que cria, revela suas idéias e nelas vai até esgotar as possibilidades de sua descoberta, como nos explica a escritora Maria Alice Barroso:

esse é o terreno de Nelida Piñon, as idéias, os pensamentos do ser humano, e é sobre o cérebro de seus personagens que ela se debruça com o lúcido deleite do cientista em seu microscópio ${ }^{72}$.

Os devaneios da protagonista de "Aventura de saber" são um bom exemplo da intensidade alcançada pelo narrador de Nelida. No conto há um jogo entre imaginação/contemplação que expõe os pensamentos da personagem em um plano quase real, e terminamos por nos perguntar se realmente se trata de uma construção de seu imaginário. A perturbação da professora ao confrontar-se diariamente com um dos meninos de sua classe gera um estado de alma que a faz dar-se ao mundo sem medidas.

A professora entrega-se às possibilidades que trazem o rosto limpo e claro do aluno. Nele ela vê refletida sua velhice, e nem por isso nega-se ao perigo de desejá-lo intensamente. Essa teia de sentimentos e pensamentos é apresentada pelo narrador como na descrição de uma travessia:

E como percebeu que ia sofrer toda a vida, analisou lentamente todos os rostos, não que procurasse um outro rosto de menino que substituísse aquêle que ela amava, mas procurando confundir entre tantos aquêle rosto único. A professora compreendia que as coisas a abatessem, que o menino amasse uma menina. (PIÑON, 1966, p. 76).

Sem a proteção da esperança ou a estratégia da fuga, a personagem feminina de Piñon insere-se no mundo que resulta de seu fluxo de idéias e nas impressões que

${ }^{72}$ PIÑON, Nelida. Tempo das frutas. Prefácio: Maria Alice Barroso, Rio de Janeiro: José Alvaro Editor, 1966, p. 10 . 
a conduzem ao outro. Ela é posta em minúcia de análise pelo narrador e cumpre seu trajeto, sem estancar diante das próprias emoções, não havendo então o momento do choque, que é tão presente nas personagens de Lispector. As mulheres criadas por Nélida Piñon possuem uma força acima do humano e por isso não se deixam tocar pela crueza do cotidiano que aqui nos parece mais subjetivado do que nos enredos clariceanos.

No que diz respeito à invenção da linguagem e às personagens femininas, as escritas de Nélida Piñon e Clarice Lispector estão próximas, pois a primeira condensa em seus seres o trinômio "pensamento palavra e ação" e para traduzi-lo utiliza-se de uma linguagem que rompe com os recursos tradicionais, recusa-se "às sintaxes consagradas e facilmente comunicáveis", aventurando-se com êxito na "busca do insólito ou do novo que vem empapado do inaugural” (COELHO, 1993, p. 275). Daí a autora de origem espanhola também ter sido acusada de hermetismo no início de sua carreira literária, acusação pela qual também passaram os textos clariceanos.

Neste percurso, consegue-se perceber como as narrativas de Clarice se configuram no contexto literário, comparando-se com as outras produções literárias que enfocam o universo feminino.

\subsection{Tramas e traços: o universo de Maria Judite de Carvalho}

Penso que isso se passa com todos os escritores. Há uma parte de nós que não é nossa, é a da sociedade em que vivemos, e que está inserida na literatura que fazemos. Nós vivemos numa época, somos influenciados por ela e isso reflecte-se na nossa obra.

Natália Nunes

Mesmo tendo uma fortuna crítica bem ampla, até o presente momento não temos notícia de estudos sobre a obra de Maria Judite de Carvalho que tenham como alvo aspectos histórico-sociais, tais como as relações das personagens com a sociedade em que estavam inseridas, ou a rua como busca de liberdade, ou mesmo os olhos observadores das personagens que estão quase sempre analisando as relações e os papéis sociais. 
Um dos aspectos assinalados pela crítica é o de que os fatos sociais não são o grande alvo das novelas e contos de Maria Judite, no entanto, ao nos aproximarmos de sua obra, é possível observar que no grito sufocado de suas personagens femininas também encontramos muito de protesto e de angústia pela condição social opressora. Há também alguns textos da crítica que ressaltam na obra juditiana os malogros das mulheres casadas para as quais as obrigações do cotidiano são obstáculos para a liberdade e, nesse sentido, também as narrativas da autora assumem um certo ar de protesto contra a estrutura social.

O crítico Fernando Mendonça traça um interessante panorama das particularidades da escrita juditiana em relação a essa denúncia sutil sobre a condição feminina. Segundo o crítico as narrativas da autora "são janelas indiscretas, abertas sobre a vida de mulheres". Essas têm seus conflitos psicológicos e sociais analisados constantemente, seja em reflexões, diálogos ou mesmo quando estão confinadas em um espaço solitário. E essas mulheres são apresentadas "como seres amargurados, frustrados, cientes apenas de que o mundo dos outros é um desgosto sem espanto, a flor aberta da mágoa sem surpresa" ${ }^{\sharp 3}$.

O mundo em que essas personagens estão mergulhadas, segundo Mendonça, é a tal ponto angustiante que dele não há como sair, voltar também é algo impossível, então a elas resta a arma da memória que geralmente as remete a um tempo no qual a vida era possível, mesmo sem felicidade. E o adversário desse mundo sem saída é representado de dois modos: por um homem, sobre o qual a mulher deposita sua carga de dor-esperança; ou pelo tempo, vilão que leva consigo a leveza da juventude.

O embate seja com o outro ou com o tempo vilão da idade, acontece no espaço da limitação em que se desenvolvem as relações inter-pessoais, sem lugar para grandes emoções ou amores desmedidos. Essas mulheres não apresentam talento para transitar dentro de uma relação, seja ela amorosa ou social, há um malestar constante como se também não coubessem no mundo, então o que podemos ver nelas:

\footnotetext{
${ }^{73}$ MENDONÇA, Fernando. "Ficção de autoria feminina ou o sabor da solidão". In A literatura portuguesa no século XX. São Paulo, Hucitec, 1973, p. 173.
} 
é a sensação de que se movem num espaço ou num caminho sem a sinalização adequada. $O$ mundo inviolado que sonharam é permanentemente violado pela displicência e até pela inaptidão dos homens a quem afloraram. (MENDONÇA, 1973, p. 173).

A constante inquietação que as personagens apresentam diante de si mesmas, a falência das relações sociais e a inadequação a um mundo degradado fazem com que busquem viver em constante fuga, seja se atirando por janelas como a personagem do conto "O grito". Ou partindo com uma mala e o coração repleto por um destino ilusório, como no conto "Adelaide", em que a protagonista deixa-se ficar inerte ao descobrir que acreditara demais nas palavras de um homem desconhecido.

A impossibilidade de realizar algo ou de ter esperanças é marcante na quase totalidade dos textos da ficcionista, gestos são contidos e palavras aparentemente simples não podem ser ditas, e mesmo quando ouvir alguém é a única solução para o caos, o cotidiano impossibilita o contato ou a mínima expressão de afeto. Temos como exemplo o caso de Flores, a protagonista de "Flores ao telefone" que, buscando fugir de seu completo estado de solidão, tenta falar com várias pessoas ao telefone, porém sem sucesso, pois todos estão comprometidos com suas próprias angústias, comprovando que: "As mulheres de Maria Judite de Carvalho não têm emenda, não rompem o código, permanecem na fronteira do acessível sem esperança, aguardam inertes a passagem dos dias" (MENDONÇA, 1973, p. 174).

Conforme nos referimos acima, para as protagonistas do universo juditiano não há como voltar ou concertar a vida quebrada, fugir também é impossível, por isso o primeiro pensamento que lhes acode é o suicídio, e quando não o fazem confessam ser por fraqueza. Filhos, maridos ou quaisquer outros laços são amputados da vida dessas personagens, ou fazem parte de um passado para o qual só é possível voltar através da memória, ou então se deixam estar em uma existência em que tudo poderia "ter sido", mas nada houve de fato.

São mulheres traídas por homens que se não amam pelo menos manifestam afeto, frustradas por amizades superficiais, e mesmo as relações familiares estão sob a lente juditiana. Dora Rosário é a protagonista da novela Os armários vazios, uma mulher "sem idade e sem solução" que após dez anos de viuvez aceita a idéia de um outro homem em sua vida, mas o perde para a filha de 17 anos. A angústia que já lhe 
acompanhava durante o enredo torna-se mais forte juntando-se à sensação de perder mesmo o que não possuía. A conseqüência será o descrédito em si, no outro e no mundo, chegando ao final de sua história como "uma mulher cinzenta, um pouco curvada, perdida na cidade deserta depois da peste e do saque". (CARVALHO, 1966, P. 45).

Durante os vários anos em que escreveu crônicas para jornais de Lisboa, Maria Judite assumiu ainda mais a posição de observadora da sociedade ao seu redor. Como cronista a autora tenta mostrar à mulher que deve negar-se à organização de poderes e leis que a fazem se ver sempre preenchendo os mesmos pequenos espaços criados para ela. A narradora-cronista propõe um caminho de descoberta que conduz ao banimento; ao ver-se de fora de seu papel, expressando total consciência de si mesma, ela constrói em seus textos espelhos para que a leitora se veja:

Por que ela não era feliz, nunca o fora, nunca o seria, com as tais pequenas coisas da vida. $\mathrm{E}$ as mulheres felizes, por acaso ou por escolha, davam-lhe sempre uma grande, uma infinita tristeza misturada com um pouco de inveja, com um pouco de troça. Era uma mulher inteligente, solitária e sem solução. (CARVALHO, 1979, p. 101)

Os textos da autora induzem a mulher de seu tempo a ter certa consciência de que sua existência está sempre relacionada ao outro, para quem ela deverá dedicar sua vida. No entanto observar tal realidade pode tornar-se perigoso, como previne a própria ficcionista: "Se você olhar em volta com olhos de ver, bem abertos, se se esquecer de si própria durante uns minutinhos... Meu Deus, o que você vê!" (CARVALHO, 2002, p. 74). A condição de exílio e fuga que observamos nas personagens juditianas vem justamente de um olhar em relação a si e ao tempo, seja vindo de um passado que aprisiona em lembranças dolorosas; ou lançado para entender um futuro que se torna impossível.

As características apontadas nas crônicas são marcantes também no universo dos contos e se revelam no jogo entre autor/narrador ${ }^{74}$, que se faz quase personagem a si e ao leitor, em um tempo presente que incomoda. Eis uma das características que

\footnotetext{
${ }^{74}$ Sobre o tema consultar NAVAS, Ruth V.S. "Escrever sobre Maria Judite de Carvalho". In Vértice, n. 32, nov. 1990, Lisboa.
} 
tornam suas crônicas atemporais e seus contos obras que fazem parte da melhor literatura da segunda metade do século XX em Portugal: "Caminhamos, por assim dizer, no fio da navalha e estamos sempre, portanto, à espera do pior. Se nos distrairmos, por pouco que seja, se alguém se distrai, é o fim" (CARVALHO, 2002, p. 41).

Através da análise e desvendamento de conceitos e comportamentos criados e defendidos pela sociedade para a mulher, a autora abre cada vez mais o caminho para o exílio. Aqui vemos também um outro ponto de semelhança entre as novelas, contos e crônicas da autora: o desejo de romper com a condição limitadora imposta ao feminino. Ao colocar-se em alguns enredos como um quase-personagem, o narrador confunde-se ao universo dos textos, dialoga com a leitora, aconselha-a, ou tenta convencê-la da importância de fugir da alienação proposta à mulher:

Mulheres super-perfeitas mas inexpressivas, geladas, exibem perfumes luxuosos, jóias raras, peles preciosas, quase extintas no mundo. Há frascos de cristal de rocha, boiões de tartaruga. E por entre tudo aquilo os rostos mortos das mulheres-cartaz (CARVALHO, 1979, p. 160)

Os vários temas abordados pela autora levam a refletir sobre a organização social não só da Lisboa da época, mas do mundo e do cotidiano em geral. O trabalho doméstico é freqüentemente abordado e de uma maneira que ressalta o jogo de poder existente na organização da família e que faz com que a mulher seja a ele submetida sem contestar sua posição de indivíduo explorado, apenas se sujeita ao aprisionamento do espaço da casa e às obrigações diárias.

Em alguns dos enredos juditianos há a breve sugestão do narrador de um caminho para onde fugir, mas é apenas uma ilusão que logo se dissipa. Seja a tentativa de se emancipar por uma profissão, uma atividade a desenvolver, ou mesmo de fazer a vida ter sentido pelo amor, e quando nada disso é possível, novamente se expõe o conflito: como pode a mulher atingir tal êxito em um mundo de homens?

É que os homens exigem muito mais "companheirismo" do que as mulheres. Acham que elas, só porque são mulheres, devem desistir sem amargura da sua própria personalidade e vestir a dos maridos a fim de 
serem as companheiras de quem nunca fez esforço para ser companheiro (CARVALHO, 2002, p. 175).

$\mathrm{Na}$ crônica "Encontro", que figura entre os textos com títulos, no final de Diários de Emília bravo, temos de fato uma breve crônica/conto em que o narrador joga com contradições que começam desde o título, uma vez que a situação exposta nos leva a um (des)encontro da protagonista com antigas colegas de colégio. Em uma tarde passada com as quatro mulheres ela transita inquieta dentro de um universo que também deveria ser o seu, mas ao qual ela não pertence. O relato nos apresenta uma imagem do papel que se espera da mulher na sociedade da época; através das vidas bem arrumadas das quatro personagens vemos o estreito caminho por onde marcham, adequando sempre suas vidas a um papel que figure dentro do quadro desenhado para o feminino, ligando-se a banalidades que as afastem de si mesmas:

Veio o chá e também fiquei a saber que uma delas fazia dieta, outra era muito gulosa, a terceira não tinha problemas de alimentação, a quarta tinha alguns. E falou-se de ginástica, de crianças, do problema das empregadas domésticas. (CARVALHO, 2002, p. 317)

As impressões da narradora-personagem são contadas como se a um outro de si mesma, num relato de frases cortadas, reticentes, suprimidas por reflexões do tipo: "Agora... Bem, é de fato melhor esquecer" (CARVALHO; 2002, p. 317). O diálogo com o duplo a faz encontrar-se ainda mais consigo, e com a situação "demasiado deprimente" que havia passado naquela tarde com as colegas que se tornavam "vagos fantasmas" dentro da vida que ela agora habitava. À margem de um papel definido como o das outras, não havia para ela um lugar social.

Através da situação vivida pela personagem em "Encontro" a autora detalha o jogo social e aproxima-se da leitora; descreve com minúcia e sutileza as inquietudes dessa mulher fazendo com que, através da leitura, ela possa observar e intervir na estrutura da qual faz parte. Dessa forma, podemos dizer que as crônicas juditianas, assim como seus contos e novelas, caminham juntas com o desejo de mudança e com 
as inquietudes que manifestavam as mulheres nos anos 1970, como os explica Ruth Navas:

Maria Judite de Carvalho contava histórias de uma forma aparentemente espontânea, criando personagens e ambientes, próprios do espaço sócio-afectivo de muitas mulheres portuguesas da época"75.

O retrato das quatro mulheres reunidas em uma tarde de sábado nos permite analisar os diferentes papéis sociais ocupados por cada uma delas: Cecília, dedicada aos cinco filhos e ao marido médico; Adélia, sempre na mesma cidade a fabricar flores incansavelmente; Alice, sempre solteira; e Júlia que tentava a sorte em seu segundo casamento. O retrato das quatro mulheres é capaz de dar conta de vários dos anseios, medos e angústias comuns à sociedade feminina de então.

Uma vez que a protagonista não se encontra em nenhum dos papéis citados, sente-se estranha a todas as colegas e fala como alguém que habitasse de fora do mundo de relações e afazeres ao qual as demais estão ligadas: "Foi demasiado deprimente, como já te disse e repito. E o pior é que desde aquele dia ando a pensar em como é que elas me terão visto. Que história!" (CARVALHO; 2002, p. 318).

No quadro social de "Encontro" vemos formas de submissão da mulher ao lugar que a ela é destinado, confirmando sua dependência. A situação de exílio apresenta-se nas reflexões e inquietudes da protagonista que sai do quadro social que a cerca negando-se a ele. Porém ela terá como conseqüência a solidão e a angústia de se ver frente a frente com o quadro que as demais concebem como sendo de uma vida "feliz".

O estado de passividade é outro fator muito presente nas narrativas juditianas. O convite a exilar-se desse estado e a tomar o próprio destino é feito constantemente pelo narrador. Mas a aparente saída ou fuga das leis que regem o espaço social da mulher não representa no universo juditiano uma solução. Sendo mais um caminho que conduz ao estado de isolamento, o que vai se revelar mais fortemente nos enredos das narrativas curtas da autora.

\footnotetext{
${ }^{75}$ NAVAS, Ruth. Leituras hipertextuais das crônicas de Maria Judite de Carvalho. Lisboa: Edições Colibri, 2004, p. 11.
} 
Como exemplo do estado de solidão do feminino, temos o conto "O grito" do volume Seta despedida, em cuja história vemos a protagonista, Camila, que ensaia projetar-se em várias maneiras de viver, mãe, escritora, pintora, mas não consegue caminhar dentro de nenhuma delas. Nada é marcante em sua existência, nem mesmo a expressão do rosto ou a voz e, a cada falência consigo e com o outro, ela caminha um pouco mais para dentro de si até sentir-se em total isolamento: "E foi se tornando cada vez mais vazia e mais só" (CARVALHO, 1995, p. 117). Sua angústia atinge o insuportável e ela reage atirando-se pela janela num exílio final, que, se não era a solução, poderia ser a saída para o seu não-pertencimento.

A protagonista de "O grito" assim como aquela de "Encontro" partilha a angústia de não ter voz nem lugar para si, de ter que calar o desejo de gritar. É por elas e por todas as demais que ouvimos os ruídos de vozes e pequenos protestos da autora. Detalhes mínimos, vestígios do cotidiano se juntam para construir a grande denúncia, a fala daquelas que não têm voz e que muitas vezes não se dão conta disso, e é também por elas que lemos a palavra forte de Maria Judite de Carvalho, com seu senso para ver e ouvir mesmo o que se quer esconder.

A história da literatura portuguesa nos mostra que os anos 50 foram marcados por mudanças literárias importantes, entre elas o considerável aumento do número de escritoras, resultando no aumento da literatura de autoria feminina. Não sendo esse um fenômeno apenas português, vários autores reconhecem o considerável crescimento da literatura de autoria feminina como um acontecimento universal do período pós-guerra, entre eles José Antonio Saraiva.

O teórico ressalta o quanto em Portugal esta tendência teve um crescimento muito além dos demais paises, guardando um "extraordinário relevo histórico-social e qualitativo". Algumas autoras, ainda que bem mencionadas pela crítica, ficaram em um único livro, como se assim tivessem esgotado tudo que tinham para dizer. Tal fenômeno aparece como conseqüência das várias mudanças sociais que ocorriam na época, como defende Saraiva:

o aspecto social do fenômeno como consciência a cerca de situações femininas típicas na sociedade portuguesa; e isso liga-se a fatores como 
a crescente entrada das mulheres nas profissões intelectuais e certa atenuação das dependências domesticas nas classes medias" (SARAIVA, 2000:1100).

Muitas foram as escritoras portuguesas que se destacaram no período acima citado, para nos referirmos a apenas algumas, levando-se em consideração a palavra da crítica e o período próximo ao que escreveu Maria Judite. Agustina Bessa-Luís está entre as escritoras que construíram densa carreira literária, sendo sua primeira publicação Mundo fechado, 1948, muito bem recebida por diferentes escritores, entre eles Ferreira de Castro, que se manifesta de maneira profética em relação à jovem escritora: "No seu livro não há ingenuidades. Ele parece demonstrar todo um belo trabalho de filtragem, de controle" ${ }^{16}$. Suas personagens seguem um caminho do acidental, num jogo de idéias que burla a realidade do cotidiano, mas sem feri-lo, e onde as relações são tensas, mas guardam um fio de esperança:

Passamos hoje por um caminho que tem nele marcado outras pegadas, e ocorre-nos as histórias de outras idades. Por deserto que esteja o campo, o frio, o sol, o tempo está presente e nos penetra de sabedoria e de fortaleza. A única solidão é aquela que não tem passado ${ }^{77}$.

Agustina Bessa-Luís retrata com fidelidade certas regiões portuguesas, traduzindo de forma singela aspectos culturais e paisagens, o que não a impede de possuir também uma prosa universal, um dos motivos que faz a crítica apontá-la como uma grande escritora. Em sua obra o regional e o universal não se opõem e sim se complementam através da trajetória de suas personagens, que sabiamente vão semeando seus passos na história de um cotidiano à parte.

Segundo Álvaro Machado, a autora consegue resolver a oposição "romance regionalista versus romance universalista" de maneira genial, e trafega entre os dois com a mesma intensidade, com temas que partem de uma parte para revelar o todo, a existência humana: "Resolve essa oposição, portanto, através da cultura como elemento essencial de reflexão sobre a realidade portuguesa na sua relação com o mundo, a vários níveis" (MACHADO, 1979: 25).

\footnotetext{
${ }^{76}$ Apud MACHADO, Álvaro Manuel. Agustina Bessa-Luís, a vida e a obra. Lisboa: Editora Arcádia, 1979, p. 15.

${ }^{77}$ BESSA-LUÍS, Agustina. “A mãe de um rio”. In A brusca. Lisboa: Editora Verbo, 1971.
} 
Apesar de ser uma escritora que produziu em época diferente da de Maria Judite, não poderíamos deixar de citar o nome de Irene Lisboa, que produziu narrativas intimistas e que tinham como temática principal as angústias e o estado de solidão vistas pela perspectiva feminina. Além de terem os olhos voltados para temas parecidos, as duas autoras se aproximam também no que diz respeito à observação aguda sobre o momento social a sua volta, inclusive afirmando alguns críticos que parte da obra juditiana sofreu influência da escritora neo-realista.

Irene Lisboa contribuiu para algumas revistas neo-realistas embora afirmasse não simpatizar com as perspectivas do movimento, e dele não participar diretamente. O estado de não pertencimento da autora a rótulos ou movimentos, reflete-se no estado de exílio de suas personagens, características que também encontramos em Maria Judite. Segundo Oscar Lopes ${ }^{78}$, um dos aspectos que faz a ficcionista do neorealismo figurar entre as grandes escritoras portuguesas é a maneira como seus textos aproximam a realidade exterior ao mundo interior das personagens, sem perder o tom de protesto pela causa feminina:

É de qualquer maneira óbvio que esta obra parte de uma experiência de mulher com implantação histórica e social, e realiza mesmo o acesso possível dessa específica experiência a uma consciência basicamente narrativa e testemunhal.(LOPES, 1994, p. 198)

As argumentações acima nos mostram a importância que Clarice Lispector e Maria Judite possuem não só no contexto do país em que produziram, mas no espaço literário em geral. Observar a obra das duas ficcionistas permite também vermos duas vertentes que se mostram de grande interesse: o olhar como processo de apreender o mundo, para fazer deste um caminho de auto-conhecimento; a transgressão que surge um tanto como conseqüência desta nova visada.

A trajetória de ver o mundo e de ver-se dentro de uma condição limitada é seguida com muita dificuldade pelas personagens femininas construídas não somente pelas ficcionistas aqui comparadas, mas também pelas escritoras que foram citadas acima. O caráter transgressor que essas personagens assumem após a visada

\footnotetext{
${ }^{78}$ LOPES, Óscar. A busca de sentido: questões de literatura portuguesa. Lisboa: Editorial Caminho, 1994.
} 
diferente que estendem sobre si, o outro e o mundo ao seu redor, o que implica a construção de um novo sujeito.

A junção dessas duas vertentes é característica marcante das ficções intimistas, que abordam situações de confronto das personagens com um eu que não cabe muito bem no cotidiano e na existência que lhe são destinados. É possível observar tais características nos livros Laços de família, de Clarice Lispector; e Flores ao telefone, de Maria Judite de Carvalho, já referidos anteriormente, que serão o corpus principal deste estudo. 


\section{Retrato em carne viva: contos e (des)encantos}

E hoje mamãe cose e borda e canta no piano e faz bolinhos aos sábados, tudo pontualmente e com alegria. Tem idéias próprias, ainda, mas se resumem numa: a mulher deve sempre seguir o marido, como a parte acessória segue a essencial.

Clarice Lispector

Os dois livros de contos que nos servem como objeto principal neste estudo receberam olhares bastante significativos por parte da crítica, em ocasião da publicação. Guardadas as devidas diferenças, tanto Laços de família quanto Flores ao telefone, apresentam personagens com conflitos e angústias vividos pela mulher da época. A esperança de ser respeitada pelo casamento e a angústia pela ausência de papel social são algumas das amarguras que desfilam por entre as mulheres de classe média, e que se resultam em males sem cura e em morte, para as personagens juditianas; ou em choque e embate social, nas personagens de Clarice.

O livro Laços de família é constituído de treze contos, cinco deles já apresentados em Alguns $\operatorname{contos}^{79}$, 1952, e outros publicados na revista Senhor ${ }^{80}$. Mesmo com a sustentação de muitos críticos de que a força da escritura clariceana estava em seus romances, esse foi um de seus volumes de contos mais bem aceitos pela crítica, rendendo à autora palavras como as de Eduardo Portella ${ }^{81}$ que a colocou entre as grandes ficcionistas de sua época. Um ano depois de sua publicação tal obra daria a Clarice o prêmio Jabuti da Câmara Brasileira do Livro, como melhor livro do ano de 1961.

A escolha de Laços de família deve-se ao fato de que a maioria das narrativas tem como protagonista uma mulher que é descrita pela autora dentro do contexto familiar em que vive, a sociedade carioca dos anos 1960, o que nos servirá como fio condutor para nossa abordagem de cunho social. O mesmo se dá com a escolha de

\footnotetext{
${ }^{79}$ LISPECTOR, Clarice. Alguns contos. Rio de Janeiro, Ministério da Educação e Saúde, 1952, Cadernos de Cultura.

${ }^{80}$ Revista carioca lançada em 1959 e que perdurou por quase cinco anos, tendo seu papel principal no campo do jornalismo cultural.

${ }^{81}$ PORTELLA, Eduardo. “A forma expressional de Clarice Lispector", Jornal do comércio, Rio de Janeiro, 25 de setembro de 1960.
} 
Flores ao telefone, em que quase todas as histórias são significativas quanto à condição da personagem feminina e suas relações com a sociedade. É marcante nos dois livros a questão do olhar como ponto de partida para uma atitude ou um instante transgressor, e conseqüentemente levando as personagens a romperem com o próprio destino.

É importante lembrar que Laços de família é um dos volumes de contos, dentre outros da autora, no qual melhor podemos ver o retrato da sociedade carioca dos anos 60, o papel social atribuído à mulher, assim como seus deveres junto à família são recortes enfatizados em grande parte dos contos que compõem o volume. Foi com essa obra que a autora alcançou o reconhecimento como contista junto à crítica e ao público da época, saindo um pouco da categoria de autora "difícil" que the havia sido atribuída após sua obra inaugural, Perto do coração selvagem, 1943.

Nos contos que compõem o livro há uma harmonia entre a linguagem, o existencial e o social que cerca as personagens. Neles Clarice não abandona seu caráter intimista e particular de tratar o humano. A autora analisa profundamente pequenos pontos dentro de fatos comuns das personagens, como nas palavras de Walnice Nogueira Galvão ${ }^{82}$ :

A nota que a distinguiu foi a da introspecção, que até o fim marcará sua obra. Ali o exame tenso e impiedoso das intermitências da consciência se casa em registro extremamente moderno com certas técnicas típicas da prosa do século XX (GALVÃO, 2005, p. 8)

Dentre os vários fatores que contribuíram para a grandiosidade e complexidade dos textos da autora, Galvão aponta a adolescência jornalística no Rio de Janeiro, o cosmopolismo referente aos anos de vivência de Lispector no exterior e a "coincidência no tempo com a ascensão dos movimentos feministas" (GALVÃO, 2001, p. 8). São fatores que contribuíram para que sua obra fosse bastante traduzida em vários países, principalmente naqueles onde os movimentos sobre o feminino tiveram grande repercussão, como Estados Unidos e França. Neste último país a autora tem quase todos os seus livros traduzidos e é estudada nas universidades francesas por

\footnotetext{
${ }^{82}$ GALVÃO, Walnice Nogueira. "Entre o silêncio e a vertigem", prefácio do livro Melhores contos, Clarice Lispector. Direção de Edla van Steen. São Paulo: Editora Global, 2001, p. 8.
} 
Hélène Cixous, Julia Kristeva, entre outras personalidades importantes da crítica dos estudos do feminino.

Os textos clariceanos dão voz a "meninas, velhinhas donas de casa, escritoras, pobres, ricas, criadas, patroas, cultas e inteligentes ou então analfabetas, rebeldes ou enganosamente acomodadas" (GALVÃO; 2001, p. 11). Em todos os papéis, o narrador será um denunciador dos tantos obstáculos enfrentados pelas personagens femininas, mas sem deixar escapar os importantes detalhes de cada trajetória apresentada nos enredos. O conto "Feliz aniversário" é um bom exemplo de uma voz dada à velha matriarca, que tem os pensamentos e as sensações transmitidos pelo narrador:

Eles se mexiam agitados, rindo, a sua família. E ela era a mãe de todos. $E$ se de repente não se ergueu, como um morto se levanta devagar e obriga mudez e terror aos vivos, a aniversariante ficou mais dura na cadeira, e mais alta. Ela era a mãe de todos. E como a presilha a sufocasse, ela era a mãe de todos e, impotente à cadeira, desprezavaos. (FA, p. 78)

O caráter feminino da obra clariceana também foi pioneiramente observado por Gilda de Melo e Souza, que enfatizou a importância dada pela autora aos detalhes aparentemente insignificantes que configuram o horizonte doméstico feminino. O que a ensaísta associa a uma espécie de visão "míope" atribuída à mulher, tal miopia compõe também a astúcia da autora que faz de situações aparentemente banais instantes ricos para as personagens:

E como descreve as coisas pelo avesso, quando se volta para a realidade exterior detém-se de preferência, não no que os sentidos apreendem, mas no que deixam escapar, evitando as zonas de luz para se perder na imprecisa área de sombra onde os contornos submergem. (SOUZA, 1980, p. 16)

Benedito Nunes refere-se ao livro como sendo aquele que "conquistou o público universitário e despertou interesse pelos outros romances da autora" (NUNES, 1998, p.35). Laços de família seria, segundo o crítico, responsável pelo início de uma segunda fase na obra da autora caracterizada por sua maior aceitação pela crítica e 
pela recepção do leitor. A aproximação entre os enredos nos permite visualizar o binômio família/sociedade, exemplificando-se ainda mais na dificuldade das personagens em exercerem o papel social a elas destinado. Acreditamos, como muitos críticos, ser este o volume de contos no qual a autora melhor desenha os quadros da condição feminina da época.

A seleção das narrativas segue dois critérios, válidos para as duas escritoras: o primeiro diz respeito às personagens femininas que nos permitem ver a condição social da mulher. O segundo critério refere-se aos níveis de convergência e divergência das narrativas de Clarice e Maria Judite. É entre as personagens, os enredos, e as particularidades de cada autora que construiremos o eixo comparativo deste estudo.

Dos contos clariceanos trabalharemos "Amor", "Preciosidade", "A imitação da rosa", "Os laços de família", "O búfalo". Tal escolha também se sustenta no tema por nós abordado e no fato de os enredos seguirem um caminho muito próximo com características mais ou menos comuns. No entanto, a própria aproximação temática gera os pontos de divergência, tanto no que diz respeito à trajetória percorrida por grande parte das personagens, como na maneira como rompem com o mundo ao redor. Vale lembrar, entretanto, que tais personagens se aproximam no que diz respeito à circularidade dos enredos e à passividade que assumem diante de si mesmas.

O conjunto dos contos segue a linha da literatura intimista, porém sem deixar de lado as referências à sociedade carioca da época, tais como os retratos das vidas de mulheres de classe média, vivendo quase sempre conduzidas pela mão de um homem. Quando da publicação da terceira edição do livro, em 1965, o cronista e amigo da autora, Rubem Braga, aponta para os laços sociais existentes nas narrativas, e para o cuidado da autora em associar as personagens aos diferentes cenários do Rio de Janeiro:

por mais introspectiva que seja a escritora, ela não é alerta apenas aos tumultos e confusões da alma, mas também, com uma sensibilidade especial, às luzes, aos rumores, às brisas e à temperatura, a detalhes da paisagem e do ambiente ${ }^{83}$.

\footnotetext{
${ }^{83}$ BRAGA, Rubem. "Clarice Lispector, uma contista carioca", in revista Manchete, 11 de dezembro de 1965.
} 
As personagens do livro dialogam entre si através de diferentes elos de comportamento, evidenciando-se nos pares que compartilham situações semelhantes ainda que com reações adversas. As personagens muitas vezes dão a impressão de ultrapassarem de uma narrativa a outra os seus destinos e vão criando força e independência a tal ponto que, em alguns momentos, constroem-se por si mesmas. Suas vidas deixam-se conhecer além do simples relato de começo, meio e fim, e as sensações e sentimentos são de tal maneira pulsantes, que não parecem ser contados, mas expressos, o que contagia personagem, fato e leitor.

Assim, ao passar de um enredo a outro se fortalece cada vez mais a impressão de um acordo entre a estrutura e os fatos narrados, que mesmo sutis vão se alicerçando nas experiências vividas e transformadas pela linguagem resultante de um instante de "choque" ou reflexão das personagens. O texto da prosa cresce em importância juntamente com o instante convulso. Nesse momento, a palavra ganha proporções imensas e muito acertadas nos detalhes que se aliam à precisão do narrado, como descrevem as palavras de Roberto C. Santos:

a escolha e o emprego exato do vocábulo, a justa construção sintática (nos contos, há verdades que são expressas claramente, na frase mais reta; outras que obrigam à sinuosidade, ao distúrbio, à nublagem). Os recursos advindos de uma escolha e de um remanejamento de valores de que se vai tecendo o projeto escritural de Clarice favorecem a passagem da vivência à obra. ${ }^{84}$

A utilização dos espaços pela personagem também ganha proporções diferenciadas, as experiências invadem as casas, quebrando a aparente segurança. Bondes levam a lugares totalmente à revelia do esperado, o cotidiano se (des)arruma em função de um instante maior que não pode esperar para entoar seu grito. Jardins se redimensionam, tornando-se labirintos de onde é quase impossível sair, ou ainda salas que se agigantam e se tornam perigosos caminhos para fora. Os ambientes se perdem também diante de flores cheias de dolorosa beleza lançando o tiro certo contra os costumes arrumados nas gavetas, conforme os papéis sociais.

\footnotetext{
${ }^{84}$ SANTOS, Roberto Corrêa dos. “Artes de fiandeira”, in Laços de família. Rio de Janeiro: Francisco Alves, 1995, p. 7.
} 
Tudo se passa em um tempo muito bem elaborado. Os momentos que rompem com o relógio para crescerem à revelia e na medida das sensações que serão mais ou menos duradouras, quanto mais a personagem lhes der vazão. Durações bergsonianas ${ }^{85}$ que tomam o segundo pela eternidade de seu efeito e vão libertando e aprisionando as personagens em jardins, casas ou sofás, numa elasticidade temporal que atrai e assusta, mas que acompanha compassadamente "uma peregrinação do desejo insatisfeito, convertido num movimento de errância, numa intérmina busca'86.

$O$ trabalho entre estrutura, verbo e personagem contribui para a riqueza dos laços que envolvem e afastam a atenção do leitor, tornando-se inevitável se misturar com as várias veredas construídas por situações as mais variadas. "O universo feminino é (des)construído com lentes que mostram detalhes que chocam e prendem sem apontar vítima ou algoz, sem defesa ou acusação. Porém com traços de denúncia que em momentos se mostram em outros se escondem, como geralmente vemos nos jogos sutis presentes nas narrativas de Lispector.

Flores ao telefone é o livro de contos de Maria Judite de Carvalho que aqui analisaremos. As narrativas escolhidas se constroem em torno de uma personagem imersa no conflito eu/mundo, angustiando-se com o destino, mas sem confrontá-lo. As catorze narrativas presentes no livro são relatos de situações-limite na vida de mulheres muitas vezes presas por muros interiores, imersas em situações das quais não podem sair, ou porque lhes é impossível ou porque desistiram. A respeito dos contos João Gaspar Simões ${ }^{87}$ observa que: "Flores ao telefone oferece-nos pequenos quadros, devidamente emoldurados, onde tudo está no seu lugar: perspectiva, cor, desenho, sombras, música" (SIMÕES, 1981, p. 293). As histórias enfatizam angústias e malogros vividos pelas protagonistas, certamente apontando para um sofrimento humano que não parece ter solução.

\footnotetext{
${ }^{85}$ A respeito da durée e do tempo em Clarice Lispector ver NUNES, Benedito. O Drama da Linguagem: Uma Leitura de Clarice Lispector. 2.ed. São Paulo, Ática, 1972.

${ }^{86}$ NUNES, Benedito. "A narração desarvorada". In Cadernos de Literatura Brasileira:Clarice Lispector. São Paulo: Instituto Moreira Salles, edição especial, n. 17 e 18, Dezembro de 2004.

${ }^{87}$ SIMÕES, João Gaspar. "Maria Judite de Carvalho”, em Crítica IV. Lisboa, Casa da Moeda, 1981, p. 294.
} 
Há em Flores ao telefone aspectos marcantes, seja na estrutura ou na temática que conduz os enredos. No tocante ao último aspecto encontramos várias aproximações com Laços de família, que serão enumeradas no decorrer do capítulo. As estórias das personagens femininas partem de acontecimentos simples do cotidiano, mas sempre abrindo veredas para apreensões e choques maiores, reflexões inquietantes que levam as mulheres para fora do dia-a-dia comum. Sobre os enredos juditianos, José Manoel Esteves afirma:

O fio condutor desliza do mundo exterior (o datável, o factual) para o mundo interior (o perturbado, o conflito ritmizado) fixando aquilo que resiste aos acontecimentos e que permanece contido e velado no acto do dia-a-dia ${ }^{88}$.

Os espaços representam geralmente confinamentos, sejam quartos, casas, ou mesmo na rua, existe a ameaça do aprisionamento que de fato está no próprio eu e no incômodo causado pela falência das relações. O conto que dá título ao livro tem como ambiente o quarto de onde a personagem tenta vencer a solidão. Sentada ao lado do telefone, tenta atingir as pessoas que ela pensa poderem salvá-la, no entanto as várias vozes que lhe chegam são negativas, confirmando seu confinamento para fora do mundo das relações sociais:

Tinha apontado três números de telefone num pedacinho de papel: o de uma colega de trabalho que sempre se mostrara simpática, o da sua melhor amiga, o do homem com quem fora casada. la gritar por socorro mas ninguém lhe dera tempo de o fazer. (FAT, p.17)

Os relatos se desenvolvem em uma linguagem simples e certeira, que apreende o narrado e o transforma em quadros que nos mostram a personagem em situações de espectadora da própria ruína. Os vários episódios que compõem o livro combinam a simplicidade da linguagem com a crueza da realidade que se apresenta diante dos seres e os verbos caminham para um passado que é evocado para suplantar o presente impossível de ser vivido. Tudo é intencional no jogo provocado

\footnotetext{
${ }^{88}$ ESTEVES, José Manuel da Costa. “A tessitura do tempo", in CARVALHO, Maria Judite de. Este Tempo, crônicas. Lisboa: Editorial Caminho,1991, p. 10.
} 
pelo narrador para evidenciar o conflito interior da personagem, portanto até mesmo a simplicidade da linguagem aponta para detalhes marcantes no enredo:

A aparente simplicidade da linguagem de Maria Judite de Carvalho não pode deixar de ser perturbadora. Uma linguagem pouco ornamentada, essencial, depurada, torna-se o lugar da interrogação do real, questionando-o, inscrevendo assim já a mudança neste tempo. (ESTEVES, 1991, p. 10)

A escrita juditiana tem como alvo descrever os detalhes do sentimento humano naquilo que falha, na falta, na ausência, na falência da tentativa de se manter em um determinado lugar social, sua missão é, como nos explica Baptista Bastos, "reestruturar os labirintos da natureza humana"89. Expondo as personagens no grau máximo de sua angústia, para que assim se acendam luzes em pontos escuros onde se perdeu o momento de viver, onde se desistiu de um sonho, ou onde se cometeu algo que destruiu tudo que aos poucos foi construído. Mas sua denúncia se faz em tom sutil, sem jamais deixar de lado a profundidade:

A sua acusação nunca adquire a tonalidade declamatória - mas é sempre provocatória, pois em ambos, protesto e acusação, reside a descrição iluminante de uma classe, ou se o desejarmos, o conceito moral de definir um estrato social em que os seus componentes destroem outros (os outros) para se libertarem do caos e da ambigüidade que se recusam a admitir neles próprios. (BASTOS, 1975, p. 12)

Encontramos em Flores ao telefone os malogros e desencontros das relações humanas, nas situações de denúncia as personagens se tornam alvos para descobrirmos como funcionam os estratos sociais e comportamentais. São vários quadros tensos nos quais não existem muitos acontecimentos, mas os poucos que ali estão são suficientes para deixar as personagens sem saída das várias teias de sofrimento e solidão. Nestas teias reside o desejo de chamar a atenção para as várias falências humanas: "Falência do amor, falência da esperança, falência do sentido da vida, falência das relações humanas, falência dos projectos.” (BASTOS, 1975, p. 12).

\footnotetext{
${ }^{89}$ BASTOS, Baptista. "Maria Judite de Carvalho: uma ternura magoada". In A janela fingida. Lisboa, Seara Nova, 1975, p. 12.
} 
É com observação profunda da sociedade e uma exposição crua e antiromântica que nos vários episódios desta obra a autora nos confronta com a dificuldade de nos inserirmos nas ilegalidades sociais às quais estão fadadas as protagonistas dos enredos de grande parte da obra juditiana. Intitulando a construção dos contos do referido volume de "um jogo muito feminino", João José Cochofel ${ }^{90}$ afirma que mesmo de forma particular Maria Judite constrói tais enredos sem ignorar as marcas da narrativa moderna, tais como alteração do tempo ou fracionamento da ação. E assim define o tecido no qual a autora:

vai reunindo farrapos de intriga, miudezas da amizade ou do amor, recordações, sentimentos desgarrados, minúcias de observação das fisionomias, das atitudes, dos gestos, até compor o quadro definitivo e muito nítido que a pouco e pouco se completa. (COCHOFEL, 1982, p. 106)

As análises serão voltadas para os seguintes contos: "A estranha ressonância do nome de Alma", "Adelaide", "Um diário para saudade", "O aquário", "Carta aberta à família". As narrativas se inserem nos temas que acima citamos por Cochofel. Todas possuem seus pontos de tensão voltados para a criatura humana e sua essência, o que faz desses enredos cenas que se juntam para retratar a condição das personagens em seu estado de solidão.

Segundo Oscar Lopes Simões esse é um livro que apresenta "pequeninos quadros devidamente emoldurados, onde tudo está no seu lugar: perspectiva, cor, desenho, sombras, música" ${ }^{\prime 1}$. De um modo geral, a temática dos contos acima referidos está muito próxima daquela que predomina nas narrativas de Clarice Lispector. A fuga e a evasão muitas vezes surgem como recurso para transgredir com um mundo onde ver pode ser o caminho para o sofrimento, pois o resultado de elevar os olhos além daquilo que se apresenta diante delas faz dessas mulheres seres melancólicos e ausentes, vitimados por uma solidão que pode persistir mesmo quando

\footnotetext{
${ }^{90}$ COCHOFEL, João José. Críticas e crônicas, temas portugueses. Lisboa: Imprensa Nacional Casa da Moeda, 1982.

${ }^{91}$ LOPES, Óscar. "Maria Judite de Carvalho”. In Literatura portuguesa do século XX. Lisboa, Caminho, 1986.
} 
as personagens estão em companhia ${ }^{92}$. A escolha de tais contos como corpus principal baseia-se na necessidade de aprofundarmos o estudo das personagens desses enredos, partindo deles para recorrer a várias outras obras das autoras em questão.

Podemos concluir, juntamente com a crítica juditiana que a linguagem da autora em Flores ao telefone mostra-se fortemente "silenciosa, recatada como se de propósito quisesse apagar-se para fazer ressaltar o que conta" (LOPES,1986, p.132). Tal silêncio alia-se à passividade das personagens diante do curso de suas vidas, e assim constrói-se uma linguagem que corrobora com a atmosfera que move as narrativas do livro. Enquanto o fio condutor das estórias e a trajetória das personagens constroem importante semelhança entre Lispector e Carvalho, como acima citamos, a linguagem vai tecer um ponto de diferença entre os dois livros comparados.

Há na escrita juditiana o verbo tentando ser mais comedido, sem deixar de concentrar sua intensidade nas personagens. Enquanto que em Lispector observa-se a linguagem convulsa trabalhada na verborragia predominante nas narrativas de Laços de família, e em grande parte de sua obra. Sendo esse um fator que comunga com a conduta mais ativa das personagens clariceanas quando comparadas às da escritora portuguesa.

Seguiremos com as análises dos contos, através das quais poderemos confrontar convergências e divergências entre a escritura das duas ficcionistas, principalmente no que se refere à construção das personagens femininas, sua estrutura e o diálogo que estabelecem com a época em questão.

\footnotetext{
${ }^{92}$ A respeito da solidão ontológica vivida pelas personagens da autora ver A solidão de mulheres a sós, de Benilde Justo Caniato, livro com referência completa na bibliografia final.
} 


\subsection{O mundo entre paredes: mulheres domesticadas}

Trabalhavam, ganhavam a vida, eram independentes, uma ou outra tinha-se mesmo formado, aí estava depois do casamento - sempre em primeiro lugar - o grande objetivo em causa. Para além disso, o deserto. Não tinham uma religião nem um partido.

Maria Judite de Carvalho

No presente capítulo nos ocuparemos de uma questão muito delicada e de grande importância quando nos reportamos ao feminino: a figura da dona-de-casa. A questão será abordada através dos aspectos referentes ao trabalho do lar enquanto fator de contribuição para o confinamento da mulher no ambiente doméstico. Através dos contos "Amor" e "A estranha ressonância do nome de Alma", assim como os demais que surgirão no decorrer das análises, abordaremos as diferentes formas de influência que tal papel exerce na vida da mulher casada.

Para leitura dos contos utilizaremos, entre outras, a obra já citada de Simone de Beauvoir, mas especificamente o capitulo denominado "La femme mariée". Também recorreremos ao ensaio de Maria Lucia Rocha-Coutinho (1994), no qual a autora descreve de maneira detalhada e bem contextualizada os mecanismos que contribuem para a construção social da submissão feminina na família brasileira.

Um dos pontos relevantes entre os temas presentes na história da mulher é o casamento. Sua importância vai além da instituição religiosa que legaliza a união homem/mulher, ganhando força também no que diz respeito às etapas atravessadas pela esta durante os vários períodos de sua vida. Assim nos acostumamos a identificála como moça ou mulher solteira, mulher casada, viúva, isto é, sua designação se fará seguidamente em relação ao casamento.

Ao observarmos as exigências do matrimônio nos anos de 1960, percebemos que a mulher ao casar-se firma um certo acordo, aceitando ser protegida moral e economicamente pelo homem, e em troca dá-lhe sua total dedicação. Feito o enlace não haverá mais lugar para um destino livre, tão pouco uma carreira profissional ou um papel social podem ser exercidos: 
La femme en se mariant reçoit en fief une parcelle du monde; des garanties légales le défendent contre les caprices de l'homme, mais elle devient sa vassale. C'est lui qui est économiquement le chef de la communauté, et pourtant c'est lui qui l'incarne aux yeux de la société. Elle prend son nom; elle est associée à son culte, integré à sa classe, à son milieu, elle appartient à sa famille, elle devient sa "moitié» ${ }^{93}$. (BEAUVOIR, 1949, vol. II, p. 224)

A descrição de Beauvoir para a relação matrimonial explica a estreita condição sustentada pela sociedade para a mulher casada: deveres para cumprir, filhos e marido para cuidar. Sendo esta a base da vida que deve levar a dona-de-casa. Seus anseios, prazer ou vontades deverão ser domesticados pela "virtude" e o consolo de ter uma vida apaziguada deve tirar-Ihe de qualquer pensamento que questione a passividade de sua existência. É dentro desta falsa "segurança" que tentarão transitar algumas personagens de Lispector e Maria Judite, mas a falência fará com que se exilem e transgridam a falsa felicidade prometida pelo outro.

As expectativas que a mulher guarda para o casamento são diferentes das que o homem carrega para a vida a dois. Para ela, na maioria das vezes, casar-se será concretizar o sonho da união conjugal e amorosa, já para ele é a tranqüilidade e a segurança de ter alguém que dele se ocupará. Tal diferença de expectativas é responsável pelas etapas seguintes ao casamento para a mulher: frustração e melancolia. Nas personagens de Clarice e Maria Judite vemos bem definidas as posições assumidas pelo homem e pela mulher no ambiente do casamento, que podem ser resumidas nas palavras de Beauvoir:

Mais on s'aperçoit vite qu'il s'agit pour lê mari n'on d'être aimé mais de n'être pas trompé: il n'hésitera pas à infliger à sa femme un régime débilitant, à lui refuser toute culture, à l'abrutir dans la seul but de sauvegarder son honneur. Est-ce encore d'amour qui il s'agit? (...) il semble que l'homme ait le droit de choisir une femme sur qui il assouvisse ses besoins dans leur généralité qui est le gage de sa fidelité ${ }^{94}$.(BEAUVOIR, 1949, vol. II, p. 238)

\footnotetext{
${ }^{93}$ A mulher, casando, recebe como feudo uma parcela do mundo; garantias legais a protegem contra os caprichos do homem; mas ela torna-se vassala dele. Economicamente ele é o chefe da comunidade, é portanto ele quem a encarna aos olhos da sociedade. Ela toma-lhe o nome, associa-se a seu culto, integra-se em sua classe, em seu meio; pertence à família dele, fica sendo sua "metade".

${ }^{94}$ Mas percebe-se logo que para o marido não se trata de ser amado e sim de não ser enganado. Ele não hesitará em infligir à mulher um regime debilitante, vedando-lhe o acesso a qualquer cultura, embrutecendo-a com o único fim de salvaguardar sua honra. Trata-se ainda de amor? (...) parece que o homem tem o direito de escolher uma mulher com a qual satisfaça seus desejos em sua generalidade, a qual é o penhor de sua fidelidade.
} 
Visto por esse prisma o casamento é mais um desencontro de expectativas do que o encontro amoroso, o que faz com que a vida de casada para a mulher se firme no contrário da felicidade sonhada. A realidade com a qual se deparam é o infortúnio e a solidão de viver na incompreensão, esse contexto será matéria recorrente na escritura de autoria feminina. Portanto o que é retratado nos contos aqui comparados, ou citados, é semelhante ao conflito que segundo Simone de Beauvoir versa nas páginas de várias escritoras, que procuravam denunciar a quebra de ilusões que se sucedia ao casamento:

Toutes les écrivains féminins qui sont sencères ont noté cette mélancolie qui habite le coeur des "femmes de trente ans» ; c'est un trait commun aux héroïnes de Katherine Mansfield, de Doroty Parker, de Virgínia Woolf 95. (BEAUVOIR, 1949, vol. II, p. 319)

No contexto da estrutura matrimonial aparece o espaço da casa, a qual tem na figura da mulher sua maior organizadora, a quem cabe todo o peso do trabalho doméstico. Tarefas repetidas dia-a-dia sem a exigência de reflexão tornam-se para muitas um caminho por onde manter os olhos afastados de si mesma. Misturar-se constantemente à casa faz parte da relação de possuir o controle sobre o espaço, ainda que ao preço de doar-se inteiramente a ele. Dominar o espaço doméstico foi o que fez com que em países como o Brasil a mulher fosse totalmente relacionada ao lar, o que the rendeu o título que perdura até hoje entre nós, embora com menos freqüência: o de rainha do $\operatorname{lar}^{96}$.

O trabalho desenvolvido no interior da casa além de não ser valorizado como produção ou contribuição social, vai prendê-la à obrigação de limitar sua existência ao espaço interno, ao qual ela entregará o tempo que poderia ser dedicado a si mesma:

La même cause qui avait assuré à la femme son autorité antérieure dans la maison: son confinement dans le travaux du ménage, cette même cause y assurait maintenant la preponderance de l'homme; le travail de

\footnotetext{
${ }^{95}$ Todas as escritoras que são sinceras observaram essa melancolia que habitam o coração das "mulheres de trinta anos"; é um traço comum às heroínas de Katherine Mansfield, de Doroty Parker, de Virginia Woolf.

${ }^{96}$ Essa e outras denominações que durante anos estigmatizaram a mulher brasileira, assim como os vários papéis femininos em nossa sociedade, são discutidas por Maria Lúcia Rocha-Coutinho em obra já citada anteriormente.
} 
ménage de la femme disparaissait dès lors à côté du travail productif de l'homme ;le second était tout, le premier un annexe insignifiante. ${ }^{97}$ (BEAUVOIR, 1949 vol. I, p. 100)

Submetendo-se ao marido, aos filhos e à estrutura doméstica, a mulher casada entende-se como dependente e cada vez mais se afasta do caminho de sujeito dentro da coletividade em que vive, fator que contribuirá para a afirmação do estado de passividade sempre relacionado ao feminino. Ensinada a viver em uma sociedade na qual os atos são atribuídos ao homem, a ela caberá aceitar verdades e leis impostas por este. Sem necessidade de reflexão e executado de maneira mecânica e ordenada, o trabalho doméstico será uma das peças principais dentro do quadro de alienação social, ensinando a mulher a ter paciência e a resignar-se ao confinamento.

Clarice Lispector e Maria Judite não estiveram jamais alheias aos conflitos acima citados por Beauvoir, contrariamente conseguiram construir obras que os retratam de maneira perspicaz, refletindo cada uma as particularidades da sociedade a que pertenceram. Suas personagens são construídas em ambientes que bem exemplificam o quadro da domesticação: a obsessão pela ordem, equilíbrio do espaço, arrumação de gavetas já arrumadas, para assim desviar-se dos perigosos devaneios.

São características que se encontram bem exemplificadas no conto clariceano "O triunfo" 98 , no qual a protagonista Luisa desperta na casa vazia após a partida do homem e depara-se diante da angústia da solidão e do abandono. Jorge é um intelectual que a culpa por suas fracassadas tentativas de escrever e, após forte discussão, resolve partir. Ela, Luísa, é uma mulher simples acusada de oprimir o homem com seu amor excessivo, porém seu desejo maior é tê-lo junto a si, ainda que em uma felicidade conflituosa.

Ao ver-se totalmente só entre o que ficara de Jorge, ela se refugia nas tarefas da casa, e sugestivamente vai lavar todas as roupas sujas, batendo com força nas peças e desabafando com as mãos o caos que dela havia tomado conta. No ato

\footnotetext{
${ }^{97}$ A mesma causa que assegura à mulher sua autoridade anterior dentro da casa, seu confinamento nos trabalhos domésticos, essa mesma causa assegurava agora a preponderância do homem; o trabalho doméstico da mulher desaparecia, então, ao lado do trabalho produtivo do homem; o segundo era tudo, o primeiro um anexo insignificante.

${ }^{98}$ LISPECTOR, Clarice. "O triunfo", em Outros escritos. Org. Tereza Montero e Lícia Manzo. Rio de Janeiro, Rocco, 2005. O conto foi o primeiro texto de Clarice a ser publicado em 25 de maio de 1940, no periódico carioca Pan.
} 
repetitivo e automático da lavagem Luisa reflete sobre si mesma, sobre a distância que havia entre ela e Jorge e principalmente em como sua aparente fraqueza a fazia mais forte que ele:

E como nada tivesse para fazer e temesse pensar, pegou umas peças de roupa estendidas para a lavagem e foi para o fundo do quintal, onde havia um grande tanque. Arregaçou as mangas e as calças do pijama e começou a esfregá-las com sabão. Assim inclinada, movendo os braços com veemência, o lábio inferior mordido no esforço, o sangue pulsando-lhe forte no corpo, surpreendeu a si mesma. Parou, desfranziu a testa e ficou olhando para frente. Ela, tão espiritualizada pela companhia daquele homem...Pareceu-lhe ouvir seu riso irônico, citando Shopenhauer, Platão, que pensaram e pensaram...Uma brisa doce arrepiou-lhe os fiozinhos da nuca, secou-lhe a espuma nos dedos. (LISPECTOR, 2005, p.15)

Não por acaso os filósofos Shopenhauer e Platão ${ }^{99}$, que persistem na mente de Luisa, são os que lançaram a seu tempo teorias de inferiorização e discriminação da mulher. Idéias que segregavam o feminino à alienação e que Ihes interditavam o mundo do pensamento, reafirmando os conceitos do naturalismo, que diminuíam a capacidade racional da mulher.

Vemos que já nos anos de 1940 o narrador clariceano tenta despertar para uma das injustiças que vitimava o feminino. A lavagem da roupa na narrativa é seguida de um banho no qual a renovação da água muda toda a paisagem do ambiente e a faz sentir na sua força a fraqueza do outro que certamente voltaria:

Olhou em torno de si a manhã perfeita, respirando profundamente e sentindo, quase com orgulho, o coração bater cadenciado e cheio de vida. Um morno raio de sol envolveu-a. Riu. Ele voltaria, porque ela era mais forte. (LISPECTOR, 2005, p.15)

Em "O aquário", uma das narrativas de Flores ao telefone, e que será analisada mais à frente, vemos um pouco da obsessão da protagonista por apropriarse do ambiente da casa. Com várias manobras, como mexer na disposição dos móveis da sala, a mulher tenta desviar-se de si mesma por temer entre outras coisas

\footnotetext{
${ }^{99}$ A respeito das teorias filosóficas de discriminação da mulher ver Simone de Beauvoir, a parte introdutória de Le
} deuxième sexe. 
perder-se na repetição do cotidiano. Sempre que se acostumava à decoração, era preciso mudar tudo de lugar, para assim ir "fugindo cuidadosamente às armadilhas". Mesmo que em alguns dias as coisas se tornassem as mesmas, ela tentava agarrarse à ilusão de mudança, o que era veementemente combatido pelo marido em sua tarefa de mantê-la longe da ameaça de loucura:

Era um círculo vicioso e necessário, tão necessário como a própria vida. Dir-se-ia que ele não podia sair de casa pela manhã sem ver onde ficavam os pensamentos e as palavras dela, nem entrar à noite sem verificar se estavam no mesmo sítio onde os deixara, dobrados e passados a ferro dentro da gaveta. (OA, p. 104)

A repetição e o confinamento que seguem os afazeres da casa acabam criando obstáculos para a participação das mulheres em situações sociais ou lugares públicos. O que contribui, segundo Rocha-Coutinho, para uma marginalidade social, pois são isoladas do convívio externo e desenvolvem sua vida quase sempre em função do outro, anulando o papel de sujeito: "Elas passam a ser e a viver para os outros e não para si mesmas e sua afirmação pessoal consiste precisamente em negar-se como pessoa." (ROCHA-COUTINHO, 1994, p. 33).

O trabalho doméstico, além de levar ao confinamento, não dignifica como as profissões em geral e faz com que a mulher se sinta ainda mais à margem, como alguém que executa tarefas que a segregam e que não apresentam importância pública:

É assim que o trabalho doméstico da dona-de-casa, seu valor e esforço, sua contribuição ao bem estar social, não é reconhecido como trabalho e não se reveste, portanto de prestígio social. (ROCHA-COUTINHO, 1994, p. 33)

No contexto das funções atribuídas à mulher, o trabalho do lar é visto como fator que contribui na construção de um feminino submisso e destinado ao cuidado com o outro, como veremos em muitas personagens criadas por Clarice e por Maria Judite. São mulheres que vivem sitiadas em seus pequenos espaços, resguardadas do convívio público, e em uma solidão que se mistura ao sentimento de marginalidade 
social, diante da qual nada fazem, são personagens passivas sem um espaço próprio, e sem liberdade.

Além de ter sido motivo de polêmica em debates feministas, o trabalho doméstico tem sido tema de importantes estudos sobre a condição feminina. Segundo Rocha-Coutinho, estas tarefas eram uma maneira de impedir que as mulheres fizessem parte do espaço público e de independência financeira e social. Tal espaço assumiria grande importância enquanto maneira de assegurar à mulher a condição de sujeito, permitindo-Ihe aceder à negada autonomia sobre o próprio destino:

Sua dedicação exclusiva ao trabalho doméstico impede ou dificulta a participação autônoma das mulheres nos espaços públicos, que ficam restritos aos homens, levando-as a uma marginalidade social. Além disso, o trabalho doméstico isola as mulheres no âmbito da unidade familiar, onde realizam sua tarefa de forma individual, sem organização cooperativa alguma e quase sem integração com seus pares adultos, afastando-as, assim, cada vez mais do mundo público e inibindo processos de realização pessoal. (ROCHA-COUTINHO, 1994, p. 33)

Tais características de uma conduta incentivada à domesticação serão vistas de diferentes maneiras nos enredos de alguns contos de Clarice e Maria Judite que serão analisados a seguir. 


\subsection{O ensaio de um vôo}

Mas se me torno séria e quero andar certo com o mundo, então me estraçalho e me espanto. Mesmo então de repente, rio de um riso amargo que só não é mal porque é minha condição. $A$ condição não se cura, mas o medo da condição é curável.

Clarice Lispector

O conto "Amor" nos mostra um dia na vida de Ana, alguém aparentemente simples que tenta equilibrar-se nos afazeres de todo dia. Cada instante de seu tempo é dedicado ao mundo dos filhos e do marido. Desde o início da narrativa percebemos uma falsa atmosfera de calma apontando para a fragilidade da estrutura que a mulher criara para si. Alguns indícios de um novo acontecimento pairam na descrição do ambiente doméstico ou no rápido sumário feito pelo narrador:

O calor era forte no apartamento que estavam aos poucos pagando. Mas o vento batendo nas cortinas que ela mesma cortara lembrava-lhe que se quisesse podia parar e enxugar a testa olhando o calmo horizonte. Como um lavrador. Ela plantara as sementes que tinha na mão, não outras, mas essas apenas. (A, p. 29).

Ana faz do espaço doméstico o refúgio de si mesma, ocupando-se sempre das coisas e das pessoas, ela aprendeu a doar "a tudo, tranqüilamente sua mão pequena e forte, sua corrente de vida" (A, p. 29). Manter-se em relação é o hábito de um cotidiano de fuga, doando-se cada vez mais aos instantes de ocupação. Assim Ana constrói sua receita da vida "normal".

Nos momentos nos quais não havia nada mais a que dar sua ajuda, nas perigosas horas da tarde calma, ela podia de novo sentir "uma exaltação perturbada" e reencontrar-se com o furor tão bem "arrumado". O narrador vai nos mostrando vestígios de que as coisas não são tão estáveis como parecem, e que tudo está sempre como um fio tênue, prestes a se partir: "Mas o vento batendo nas cortinas que ela mesma cortara lembrava-lhe que se quisesse podia parar e enxugar a testa, olhando o calmo horizonte" (A, p. 29).

Todos os desejos que havia nela estão suplantados pelas cenas repetidas e simples, como a de seu "marido chegando com os jornais e sorrindo de fome", 
impedindo de se entregar à perigosa reflexão e permitindo a evasão no limitado ambiente de um casamento doce e tranqüilo. Os afazeres são o tapete onde estão escondidos o perigo de se auto-observar e a inconformidade com o cotidiano do bem viver.

Ligar-se aos filhos e ao marido será o recurso de Ana para que tudo permaneça em paz. Todos os seus desejos se voltam para as tarefas domésticas. Ela então assume um papel que reafirma o conceito da femme relative, isto é, a mulher que constrói sua existência em relação ao outro. Sua vida está atrelada a obrigações com os outros, não podendo assim ser livre ou ver-se na condição de sujeito:

la femme, l'être relatif qui ne peut vivre qu'à deux, est plus souvent seule que l'homme. Lui, il trouve partout la societé, se crée des rapports nouveaux. Elle, elle n'est rien sans la famille. Et la famille l'accable ; tout le poids porte sur elle (...) son travail n'occupe pas son sprit, sa formation ne lui a donné ni le goût ni l'habitude de l'indépendance et cependant elle passe ses jounée dans la solitude (...) Son mariage la souvent éloignée du foyer paternel, de ses amitiés de jeunesse. ${ }^{100}$ (BEAUVOIR, 1949, vol II, p. 404)

Para essa mulher que sai de sua vida e veste-se do casamento, não há mais lugar fora do espaço da família, e seu único objetivo social é o de ver realizados filhos e marido, nisso consiste toda a sua empreita futura. Com Ana não é diferente, pois logo sabemos que há por trás da "cautelosa" dona de casa desejos sufocados. Seu gosto pela arte fora trocado pelas coisas que se repetiam, e sua tendência pela desordem fora arrumada, assim tudo cabia dentro do pequeno espaço do papel social que escolhera:

Todo o seu desejo vagamente artístico encaminhara-se há muito no sentido de tornar os dias realizados e belos; com o tempo seu gosto pelo decorativo se desenvolvera e suplantara a íntima desordem. Parecia ter descoberto que tudo era passível de aperfeiçoamento, a cada coisa se emprestaria uma aparência harmoniosa, a vida podia ser feita pela mão do homem. (A, p. 30)

\footnotetext{
${ }^{100}$ A mulher, ser relativo que só pode viver a dois, se acha mais freqüentemente só que o homem. Ele encontra a sociedade por toda a parte, cria relações novas para si. Ela não é nada sem a família. E a família a oprime; todo o peso lhe cai em cima (...) seu trabalho não lhe ocupa o espírito, sua formação não lhe deu nem o gosto nem o hábito da independência e, no entanto, ela passa os dias na solidão (...) Seu casamento afastou-a muitas vezes do lar paterno, das amizades da juventude.
} 
Exercer tal papel compreende também uma certa ausência das relações sociais, às quais a mulher terá acesso através do marido, sua maior ligação com o mundo. Ela segue no limitado espaço da casa, onde não é permitido questionar, mas apenas executar as repetidas ações. Ocupações constantes e eternas listas de coisas a fazer são recursos para manter-se longe de si mesma e ligada com "a raiz firme das coisas". Ana abandona seus devaneios e se deixa "cair num destino de mulher" (A, p. 32) assegurado pelo mundo simples dos que se acostumaram a fazer da existência uma repetição:

O homem com quem casara era um homem verdadeiro, os filhos que tivera eram verdadeiros. Sua juventude anterior parecia-Ihe estranha, como uma doença de vida. Dela havia aos poucos emergido para descobrir que também sem felicidade se vivia: abolindo-a, encontrara uma legião de pessoas antes invisíveis que viviam como quem trabalha - com persistência, continuidade, alegria. (A, p. 30)

O trecho acima nos revela o que de fato já conhecíamos: a aparente satisfação descrita nas primeiras linhas do conto não tem muito de verdade, sendo mais uma resignação, algo há muito guardado, a sua "doença de vida", da qual ela tenta se livrar caminhando em uma multidão de olhos fechados. A estrutura familiar é então um disfarce, um recurso encorajador para combater a "exaltação perturbada", cujos vestígios tanto tentara esconder.

É durante a saída para as compras habituais que Ana romperá a fragilidade de seu cotidiano. No bonde o vento sopra diferente, e o cansaço intenso a faz abandonarse na cadeira, entregue à imagem que lhe vem da rua: o homem cego, parado diante da própria escuridão, imagem esta aparentemente simples, mas que desestrutura a frágil proteção de Ana: "O que havia mais que fizesse Ana se aprumar em desconfiança? Alguma coisa intranqüila estava sucedendo. Então ela viu: o cego mascava chicles...Um homem cego mascava chicles" (A, p. 32). Ela ainda tenta combater o devaneio, procurando manter o pensamento nos irmãos que receberia para jantar, inútil, sua calma já havia sido trocada por uma expressão "incompreensível". 
Quebram-se os ovos trazidos em seu colo, quebra-se também o fio que há muito se vinha partindo:

A rede de tricôt era áspera entre os dedos, não íntima como quando a tricotara. A rede perdera o sentido e estar num bonde era um fio partido; não sabia o que fazer com as compras no colo. E como uma estranha música, o mundo recomeçava ao redor. (A, p. 33)

A nova imagem a desestrutura, há uma novidade quase impossível de caber na simplicidade de seus dias: ela vê através da cegueira de um homem e a visada que lança sobre sua existência faz partir algo dentro dela. Mesmo após o choque, seus olhos continuam sob efeito do deslumbramento causado pelo outro. Da rápida e intensa situação vivida, Ana terá um encontro consigo, e como conseqüência tudo ao seu redor se redimensionará em uma transformação do interior para o exterior.

Seus olhos redimensionam tudo ao seu redor, tornam-se inquisidores como há muito não ousavam ser. Aos poucos o cotidiano e seus deveres vão diminuindo em meio ao mundo que se descortina diante dela, as "obrigações" com filhos e marido são esquecidas, pois ela fora "Expulsa de seus próprios dias", e tudo se torna tão perceptível fazendo do mundo algo assustador. Uma outra percepção da vida, das pessoas e das coisas se instala em Ana e lhe impulsiona a ir adiante e quebrar a viagem rotineira das compras.

Só então percebeu que há muito passara do seu ponto de descida. $\mathrm{Na}$ fraqueza em que estava, tudo a atingia com um susto; desceu do bonde com pernas débeis, olhou em torno de si, segurando a rede suja de ovo. Por um momento não conseguia orientar-se. Parecia ter saltado no meio da noite. (A, p. 34)

O mal-estar toma conta da personagem, ganha espaço e vai minando tudo ao redor. Seus passos pela rua são sem-rumo, como se tudo nela fosse desmedido, ou ainda, como nas palavras do filósofo Benedito Nunes ${ }^{101}$, sujeita "a consciência ao descontrole do corpo" (1966, p. 20) e por instantes a mulher se ausenta da vida antes segura. De repente há diante de seus olhos um mundo onde tudo tem amplificação, ela

\footnotetext{
${ }^{101}$ NUNES, Benedito. O mundo de Clarice Lispector. Manaus, Edições Governo do Estado do Amazonas, 1966, p. 20.
} 
sente as coisas antes mesmo que cheguem, e tudo se constrói diante dela sem nenhum segredo: "São os movimentos incontroláveis, porém serenos da máquina do mundo, em pleno funcionamento. Sem descontinuidade" (1966, p. 20).

A nova percepção que toma os olhos de Ana desnuda toda a paisagem guardada pela prudência dos dias anteriores, essa nova visão pode ser definida nas palavras de Regina Pontieri ${ }^{102}$, como uma mirada pela qual "pessoas e coisas se oferecem exteriorizadas, como pura visibilidade" (1999, p. 146). Retroagindo, no conto vemos que, quase levado à condição de objeto, o cego é o agente transformador de toda a estrutura sensível que protegia o cotidiano da protagonista.

Segundo Pontieri, em alguns momentos de confronto com o objeto, a construção do olhar clariceano pode (de)formá-lo numa contemplação voraz que se traduz de várias maneiras, seja tentando imitá-lo, como em "A imitação da rosa", ou fazendo do objeto uma lente de aumento, como acontece com Ana. A crítica cita $A$ paixão segundo $\mathrm{GH}$ como grande exemplo de ver e até "devorar" com os olhos, no antológico encontro de $\mathrm{GH}$ com a barata, e na intensidade desse "olhar, pessoas e coisas se oferecem exteriorizadas como pura visibilidade" (1999, p. 146).

Na significação do olhar está um primeiro aspecto de diferenciação entre as autoras, pois para o universo das personagens juditianas o ato de ver tem maior relevância do que aquilo que é visto. O que não anula a função reveladora deste último, por isso as presenças do espelho e da janela são muito recorrentes nas obras da autora, sendo o ponto de partida para as personagens verem-se diante de uma outra realidade antes escondida.

Por um momento voltar para casa torna-se impossível, então Ana muda seu rumo e vai para o Jardim Botânico em uma tentativa de reconhecimento, enfrentando a grande dificuldade de ver além do curto espaço de seu cotidiano. A protagonista se confronta com o choque intenso, e num instante é lançada para fora das ações costumeiras do dia: "O que chamara de crise viera afinal. E sua marca era o prazer intenso com que olhava agora as coisas, sofrendo espantada". (A, p. 34). Ela misturase ao novo mundo descoberto, vai aos poucos se reconstruindo dentro da liberdade de sua percepção, como é comum às personagens clariceanas:

\footnotetext{
102 PONTIERI, Regina Lúcia. Clarice Lispector: uma poética do olhar. São Paulo, Ateliê Editorial, 1999.
} 
as muitas paixões e via-crucis não significam que o sofrimento e o medo sejam sentimentos de uma individualidade fechada a um mundo sentido como hostil. Mas é o modo mesmo pelo qual essa individualidade, abrindo-se em travessia agônica em direção ao mundo, transmuta-se em mundo ela também, momentaneamente anulando-se enquanto indivíduo. (PONTIERI, 1999, p. 151).

Desviar-se do percurso é o primeiro vestígio de sua transgressão, esquecer-se de voltar pra casa e seguir a esmo, como perdida, então as horas se confundiam, as ruas e "tudo era escuro diante dela", como "se estivesse no meio da noite" (A, p. 34). A liberdade da rua representa o perigo para alguém em estado de alerta como Ana, pois se opõe totalmente ao espaço tranqüilo da casa, é a transgressão pela liberdade de não estar entre muros e de poder ver mais intensamente a vida.

Segundo Bachelard ${ }^{103}$, a rua é contrária à segurança de um espaço conhecido e natal que é a velha morada a primeira pode significar também fuga do destino previsto e limitado. Por isso após o choque, Ana não consegue fazer o mesmo caminho de volta, e entrega-se ao perigo de continuar na rua que, como acima já dissemos, é um lugar propício ao embate com o mundo. O confronto com esse aspecto redimensionado não assusta mais Ana. Sua vida já explodira, e não havia como conter isso, pois um "cego mascando chicles mergulhara o mundo em escura sofreguidão" (A, p. 36) e tudo chegava em uma crueza e a atacava como se ela viesse de uma existência distante.

Ao entrar no Jardim Botânico ela experimenta a vida como quem chega de um nascimento, sentindo pela primeira vez que o novo "estremecia nos primeiros passos de um mundo faiscante" (A, p. 36), o jardim é todo um éden para a mulher. Não mais presa a uma lista de afazeres, ela se renova a cada paisagem vista, quase tocada por seus olhos de descobridora.

O cenário do jardim era imensamente novo, as coisas encontravam-se diferentes, "tudo era estranho, suave demais, grande demais". Ana transitava no lugar como vinda de um encantamento, e o mundo se abria em possibilidade diante dela, com toda a sua crueza. O instante de choque cresce ainda mais quando pensa na

\footnotetext{
${ }^{103}$ BACHELARD, Gaston. A poética do espaço. Trad. Rosemary Costhek Abílio. São Paulo, Martins Fontes, 2000, p. 59.
} 
questão que vai além da vida íntima e do próprio êxtase: "havia crianças e homens grandes com fome, a náusea subiu-lhe à garganta (A, p. 36).

A protagonista manifesta sua consciência em relação à condição limitada de mulher, levando a vida a executar deveres, mas também desperta para a sociedade a sua volta ao lembrar das pessoas com fome. Mas em meio à reflexão mais intensa, como num relance, Ana lembra-se dos filhos, um súbito pensamento que a arranca do êxtase, pelo qual devaneava solta na liberdade do jardim. Salva pelos fios do cotidiano, por tudo que se repetira todos os dias em sua vida, a mulher busca o caminho de volta, a força do dever a cumprir tem a capacidade de ultrapassar a imensidão do cego, vencendo o que Nunes chamará de náusea, ou ainda "uma crise que suspende a vida cotidiana da personagem" (NUNES, 1966, p. 23).

Mas quando se lembrou das crianças, diante das quais se tornara culpada, ergueu-se com uma exclamação de dor. Agarrou o embrulho, avançou pelo atalho obscuro, atingiu a alameda. Quase corria - e via o jardim em torno de si, com sua impersonalidade soberba. Sacudiu os portões fechados, sacudia-os segurando a madeira áspera.(A, p. 37)

A imagem dos filhos e com eles a idéia de sua missão social, faz a protagonista sentir-se como alguém que tenta reescrever seu papel com novo destino, uma mulher transgressora. O que se segue é a tentativa de reencontrar seu mundo, fugindo daquele modo "moralmente louco de viver", para abrigar-se novamente na inconsciência segura das crianças e do marido. O peso da família e do dever a cumprir será o ponto de apoio para voltar. Esse é um aspecto que bem se explica pela abordagem feita por Beauvoir a respeito da mulher casada diante da sociedade, um peso que leva a mesma a abdicar de vontades pessoais para fazer parte da vida do outro:

Le couple est une personne sociale, defini par la famille, la classe, le milieu, la race auxquels il appartient, rattaché par les liens d'une solidarité mécanique aux groupes qui sont situés socialement d'une manière analogue; c'est la femme qui est susceptible de l'incarner avec le plus de pureté:les relations professionnelles du mari souvent ne 
coïncident pas avec l'affirmation de as valeur sociale. ${ }^{104}$ (BEAUVOIR, 1949, vol II, p. 404)

Sua transgressão se rompe pelo retorno e conformação com o mundo bem arrumado, mas ainda assim é necessário proteger-se porque a vida tornara-se periclitante, essa vida em carne viva estava agora diante dos seus olhos, e "não havia como não olhá-la" (A, p. 38). Algo havia se partido no interior de Ana e jamais se regeneraria, ela estava pra sempre alerta em sua nova posição, às avessas de si mesma:

E, se atravessara o amor e o seu inferno, penteava-se agora diante do espelho, por um instante sem nenhum mundo no coração. Antes de se deitar, como se apagasse uma vela, soprou a pequena flama do dia. (A, p. 41)

Reconstruir-se no interior de uma vida repentinamente incômoda será um longo deserto atravessado pela protagonista. Entretanto é também um novo olhar dilatando as retinas da personagem. Conseqüentemente ela pode melhor analisar sua própria condição. Há a passagem de uma visada passiva para outra mais atenta, denunciando as falências do âmbito social e existencial, e a esse processo se segue o afastamento de Ana em relação ao seu papel social como alguém que observa a própria vida.

Segundo Alfredo Bosi ${ }^{105}$ o olhar é um dos principais sentidos para intermediar homem e sociedade, podendo também ser a saída da indiferença: "A percepção do outro depende da leitura dos seus fenômenos expressivos dos quais o olhar é o mais prenhe de significações" (BOSI, 1988, p. 77). Ao intensificar sua capacidade de perceber, Ana acende uma chama que não se apaga com a volta para casa, pois a mulher que retorna passa a ver em si mesma, no outro e no mundo, o intenso caminho que a faz descobrir-se em estado de consciência e introspecção.

\footnotetext{
${ }^{104} \mathrm{O}$ casal é uma pessoa social, definida pela família, a classe, o meio, a raça a que pertence, presa por laços de uma solidariedade mecânica aos grupos que se situam socialmente de maneira análoga; é a mulher que é suscetível de encarná-lo com mais pureza: as relações profissionais do marido muitas vezes não coincidem com a afirmação de seu valor social.

${ }^{105}$ BOSI, Alfredo. "Fenomenologia do olhar", in O olhar, org. Adauto Novaes. São Paulo, Companhia das Letras, 1988 , pp. 77 e 78.
} 
O choque e as mudanças repentinas vividas pela personagem se iniciam pelo olhar mergulhado em um novo estado, pois "O olhar condensa e projeta os estados e movimentos da alma" (BOSI, 1988, p. 78). O choque vem antes de tudo do encontro de Ana consigo mesma, aliado a uma visão da realidade para fora da janela do bonde, resultando na fuga do cotidiano e no rompimento com sua condição de mulher tolhida pelas obrigações sociais. O momento no jardim insufla a chama de uma nova conduta, desregrada, livre, exposta diante da vida, perigoso caminho a seguir.

O conto "Amor", como grande parte da obra clariceana, caracteriza-se como narrativa intimista, pois a personagem substitui o fato, suas sensações são elevadas ao máximo. Mesmo apresentando características que sinalizam as mudanças sofridas pela narrativa moderna (como veremos mais a frente em relação ao narrador), encontramos no enredo uma estrutura clássica marcada por um começo, quando a personagem é apresentada em sua vida doméstica; um meio, seu choque diante do cego e a fuga para o Jardim Botânico; e o fim, com o retorno da personagem ao espaço doméstico. "Amor" se estrutura como uma narrativa que junta recursos inovadores no que diz respeito ao narrador e à ênfase ao mundo interior da personagem, mas guarda um pouco da tradição do narrar. ${ }^{106}$

A trajetória seguida pela protagonista exemplifica uma escrita marcada por analepses $^{107}$ que enfatizam detalhes para nortear $\mathrm{o}$ sentido de um presente $\mathrm{e}$ evidenciar o conflito eu/mundo. Ana tem seu conflito moderno evidenciado também com um certo ar de denúncia expresso pelo narrador, que parece revelar em alguns momentos a voz da própria autora, com sua consciência das privações do mundo feminino. A experiência da protagonista representa de fato o quadro enfrentado pela mulher casada e atrelada a casa e aos deveres domésticos:

Mulher "abafada" por uma vida familiar, em que não cabe a expansão de suas potencialidades mais individuais e mais profundas, e em que acaba perdendo sua identidade, a qual vislumbra, temporariamente e na sua plenitude, no Jardim Botânico, para depois voltar, com a riqueza desta experiência anterior, à observadora rotina da vida doméstica ${ }^{108}$

\footnotetext{
${ }^{106}$ A esse respeito ver a já conhecida Poética, de Aristóteles.

${ }^{107}$ A esse respeito ver: GENETTE, Gerard. Discours du récit: essai de méthode. Paris : Éditions du Seuil, 2007.

${ }^{108}$ GOTLIB, Nádia Battella. Teoria do conto. São Paulo: Editora Ática, 1985, p. 54. As aspas e o itálico são da autora.
} 


\subsection{Ecos de uma imagem}

Em "A estranha ressonância do nome de Alma", acompanhamos momentos de uma mulher que, "conscientemente feia, com seu melancólico nariz comprido e uma boca grande" (AERNA, p. 22), vive limitada ao ambiente da casa, as notícias da rua the vêm apenas pelos jornais e as poucas convicções que tenta ter são regidas pelas idéias superficiais do marido, colecionador de selos. A narrativa se inicia com a tentativa de um diálogo desencontrado entre o casal, Alma comenta algo que lê no jornal, mas há entre ambos certa distância impossibilitando a comunicação.

Ela disse: "Talvez a resposta aos nossos problemas esteja precisamente fora dele", mas o marido não ouviu as suas palavras. "Na minha opinião", repetiu, "essa gente foge muito simplesmente à realidade. Quer fugir-lhe em suma. $E$ a realidade no fundo é esta, a nossa vida. O autocarro, o emprego, a casa, os problemas do dia-a-dia" (AERNA, p. 23)

O quadro aparentemente normal que nos é apresentado inicialmente, vai se modificando à medida que o narrador nos deixa conhecer, através do isolamento e das reflexões da protagonista, as nuances de insatisfação que estão presentes na vida simples de mulher casada:

Ela acompanhou-o e sentiu-se de súbito, não sabia bem porquê, infeliz. Não era a primeira vez, claro, e quando isso acontecia, costumava ir até ao espelho, olhava atentamente para aquele longo nariz, para aquela boca tão grande. Era uma visão desoladora mas ao mesmo tempo reconfortante.(AERNA, p. 23)

O enredo nos faz ver que não há alterações no cotidiano simples da mulher. Os dias se passam entre as conversas com o marido Hermes, as idas ao espelho e as ilusões que tem ao abrir os olhos no escuro da noite imaginando-se bela. Alma assume a posição de espectadora da própria condição, característica bastante recorrente no universo das personagens juditianas. A total inércia frente às angústias da vida e de suas relações com o outro fazem a mulher conformar-se a um casamento vivido no âmbito do acordo. São vidas que se juntam para a tranqüilidade de não estarem sós, mas que de fato nunca se encontraram. 
O marido de Alma, como é comum aos homens na obra de Maria Judite, representa a repressão e a impossibilidade de mudança; suas frases advindas do senso comum buscam explicar a vida. Ela o escuta como se fosse o único eco de razão que chega até seus ouvidos, não há altos e baixos e nem um outro tipo de emoção, apenas vivem na aparente ilusão de não estarem sós:

Era no entanto um bom homem, não podia queixar-se. Sossegado, trabalhador, seu amigo. Um homem com quem viver não era divertido, mas ela nunca soubera o que fosse uma vida divertida e depois fora ele o único a achar natural ela chamar-se Alma, a não se ter rido do seu nome, a dizer mesmo que ele the ficava bem. Fora também o único a querer casar com ela. Era um homem limitado, de- certo. (AERNA, p. 24)

O narrador está posicionado com a protagonista, define sua consciência e o cotidiano ao seu redor, ele domina as ilusões e devaneios de Alma, ironizando suas ingenuidades. $\mathrm{O}$ uso do discurso indireto livre ${ }^{109}$ revela um narrador que pode ser tanto independente quanto ver pelos olhos da protagonista, falar por ela e até produzir juízos sobre os pensamentos da mulher: "E ela ficou um grande bocado de olhos abertos no escuro, a pensar que era bela e se chamava Alma. Como o seu nome teria uma ressonância estranha e diferente se ela fosse bela!" (AERNA, p. 25).

No momento final do conto, o narrador acompanha a protagonista diante do espelho para compartilhar os pensamentos nos quais ela admite sua "ilusão" de que mudar a imagem poderia significar um outro destino. A voz que narra ironiza a esperança da personagem e o destino anula a possibilidade da cirurgia plástica oferecida como presente pelo suposto amigo de Hermes, a quem ele havia salvo da morte tempos antes:

Faço belas as mulheres feias (...). Ofereço-te em paga a beleza da tua mulher. Enfim, não a conheço, não sei quais as possibilidades, mas enfim, farei o impossível. De acordo? Manda-a ao consultório a qualquer hora, e eu verei. Que diga o nome, recebo-a logo. Enfim que diga o teu nome. (AERNA, p. 28)

\footnotetext{
${ }^{109}$ Segundo Todorov esse discurso tenta mascarar o discurso do autor, ou narrador, que seria o indireto, com o discurso da personagem, o direto, tendo como efeito uma certa confusão das falas de um e de outro. No conto de Maria Judite tal discurso terá o efeito de aproximar ainda mais a fala do narrador da consciência da personagem.
} 
Hermes se nega a permitir que a mulher tenha a possibilidade de sentir-se bonita e praticamente recusa a oferta do cirurgião, fazendo prevalecer seu papel de marido: "As pessoas habituam-se, de resto, a si próprias, à sua própria cara. Mudar para que?" (AERNA, p. 28). Para ela tudo continuará apenas como um sonho, pois o marido guardará para si a possibilidade de torná-la diferente, guarda consigo a oferta do amigo, ele "tinha razão, como sempre" e continuaria a recortar as ilusões da mulher conforme sua limitada maneira de viver.

As questões postas a si mesma, dúvidas, reflexões e reticências trabalham na construção de um discurso que procura transmitir a fala interior da personagem. As idéias postas em dúvida traduzem o conflito de achar-se absurda, tanto pelas horas diante do espelho, como por pensar que seria possível para ela mudar.

Foi ao quarto, viu-se ao espelho, que coisa estúpida lhe passara de repente pela cabeça! A de que aquele homem poderia...Não é verdade? Que loucura a sua. O marido tinha razão, como sempre. Enfim, como a maioria das vezes. Deus pusera no mundo gente cheia de defeitos e ordenara a toda essa gente que se amasse. (AERNA, p. 29)

As marcas do discurso, como pausas e interrogações confirmam a junção entre narrador e personagem. $\mathrm{O}$ quase desaparecimento do narrador é parte do jogo narrativo e contribui para entendermos que os momentos de Alma no espelho são de pensar consigo mesma, de confessar tudo que considera absurdos íntimos, assim como é o lugar em que ela realmente confronta-se unicamente com seu maior malogro: a própria imagem.

O relacionamento apático do casal não difere da maioria dos relacionamentos descritos nas narrativas juditianas, nas quais encontramos geralmente descritas as frustrações vividas por mulheres que solteiras, noivas, casadas ou viúvas têm seus traumas irremediáveis, e conseqüentemente uma postura pessimista e desistente perante o mundo e o outro com quem vivem. Essa última característica foi bem observada por Urbano Tavares Rodrigues, crítico português e marido da ficcionista, ao descrever as personagens juditianas: 
O repúdio do sentimentalismo, o implacável rigor da análise, certa cumplicidade com os alçapões dos seres que nunca se entregam, a adivinhação das criaturas solitárias devido a traumas da infância sem pais ou sem carinho, conduzem com segurança Maria Judite de Carvalho até o âmago das frustrações mais apagadamente terríveis. ${ }^{110}$

O perfil de Alma poderia bem se encaixar no da mulher portuguesa de meados do século XX, que condiciona a vida à "casa-prisão" sem possuir nada que vá além disso, sem manter nenhuma atividade para além do lar. Todo o seu mundo limita-se a uma espécie de ornamento da casa, por isso há uma grande angústia da protagonista em relação a própria aparência. Sua imagem a incomoda bem mais que o nome, pois em momentos de reflexão a protagonista admite que "seu nome teria uma ressonância estranha e diferente se ela fosse bela!" (AERNA, p. 25).

Não é necessário avançar muito na leitura do conto para saber que não se trata da narrativa de um fato, de um acontecimento, mas sim de alguns momentos na rotina de uma mulher casada e infeliz. O refúgio nos jornais e acontecimentos mundo à fora faz parte da luta para não estar consigo mesma. As passagens pelo espelho são inevitáveis e se tornam instantes em que nada mais existe, apenas ela e sua realidade de malogros. O espelho é um objeto fundamental dentro do espaço da casa, peça importante na construção dos pensamentos da protagonista, ele ganha destaque maior do que o conjunto do ambiente.

A ausência de beleza é um ponto que a personagem tenta esconder atrás da rotina e das divagações com Hermes, mas que escapa nos momentos de repentina infelicidade diante do espelho acusador. A dimensão de seu mundo não ultrapassa o eixo entre a visão do próprio rosto e a quase incomunicabilidade com o marido. No entanto tudo parece ser diminuído diante do conflito que a mulher trava consigo mesma a cada confronto com o espelho.

A narrativa ocupa-se de relatar os incômodos de uma aparência fora dos padrões estéticos, e de como tais incômodos podem tornar triste a vida de uma mulher nascida sob o peso das imposições sociais, dentre elas a de que ela deveria mostrarse sempre bela, como nos referimos capítulos iniciais. Ao enfatizar a importância dada

\footnotetext{
${ }^{110}$ RODRIGUES, Urbano Tavares. Ensaios de escreviver. Porto: Inova, 1970, p. 199.
} 
por Alma à beleza, a voz narradora pactua com a autora em sua crítica sobre a reificação sexual da mulher ${ }^{111}$ que, durante toda sua história, esteve relacionada à figura do belo e do esteticamente desejável. Em suas crônicas, Maria Judite faz várias referências à exigência de ser bela, que tanto atormenta a mulher lisboeta e a faz desistir de ambições sociais ou políticas:

E uma boa revista feminina? $O$ que fornece às suas leitoras uma boa revista feminina? Pois bem, é simplesmente assustador. A maneira de lhe dar com os filhos. E de maquilhar os olhos. E de "segurar" um marido. De decorar o sótão ou a casa de campo (...) Seja elegante. Este inverno usa-se. Na Primavera vai usar-se. Seja bela (...) Nunca apareça a ninguém com um ar desleixado. (CARVALHO, 2002, p. 303 - grifo da autora)

O narrador joga com a questão da aparência desde o título. Não é o som do nome da protagonista que incomoda e sim a estranha aparência de Alma, o peso que carrega vem da imagem e do fato de ser conscientemente feia. Além de sentir-se excluída pela aparência, também se sente diminuída na relação com o outro, já que suas palavras ou pensamentos são totalmente ignorados pelo marido. Hermes escuta apenas a si mesmo e vive submerso em suas regras e leis pragmáticas:

"Jornais!", disse ele. "Vamos é deitar-nos que são horas. Dez e meia, estás a ver? Como o tempo passa."

Ela acompanhou-o e sentiu-se de súbito, não sabia bem porquê, infeliz. (AERNA, p. 23 - grifos da autora)

A falta de sentido pra vida onde quase nada acontece gera um ponto de angústia nos olhos de Alma. Ela se sente menor então segue a obedecer ao marido como se quisesse lhe pedir perdão por haverem se casado. Mesmo em total ausência de manifestação amorosa entre ambos, ela se sente grata ao homem que a desposara. Tal condição, de mulher casada a faz aceitar o mal-estar causado pela aparência indesejada. Mas o fato de ter cumprido parte do papel social casando-se não finda seu drama particular, e tão pouco anula seu estado de solidão. Um cotidiano de ausências (de beleza, de filhos ou de um marido que lhe dê atenção) contribui para o vazio

\footnotetext{
${ }^{111}$ A esse respeito ver Le deuxième sexe vol. I, "Les mytes".
} 
acentuado pela falta de uma vida social ou pela execução automática das tarefas domésticas.

Alma tem um cotidiano domesticado, pois vive sob os padrões que a sociedade patriarcal da época determina para a mulher, já que não possui nada que a ligue para além dos muros da casa. O curso dos seus dias se passa unicamente no espaço interno, dividindo-se entre suas reflexões diante do espelho e as notícias de fora, trazidas pelos jornais e sempre processadas pelo marido.

Em relação à condição da mulher na vida doméstica, Simone de Beauvoir afirma que esta trará consigo sempre o vazio de exercer uma função interminável e que nada constrói, pois além de não lhe trazer reconhecimento algum, ainda a afasta de qualquer intervenção em um meio social:

Ainsi, le travail que la femme execute à líntérieur du foyer ne lui confère pas une autonomie, il n'est pas directement utile à la collectivité, il ne débouche pas sur l'avenir, il ne produit rien. II ne prend son sens et sa dignité que s'il est intégré à des existences qui se dépassent vers la societé dans la production ou l'action: c'est dire que, loin d'affanchir la matrone, il la met dans la dépendance du mari et des enfants; c'est à travers eux qu'elle se justifie: elle n'est dans leurs vies qu'une médiation inessencielle. ${ }^{112}$ (BEAUVOIR, 1949, vol. II, p. 276)

A protagonista vive em um certo estado de submissão intelectual e moral em relação ao homem, fazendo dele sua principal fonte de ligação com a vida. Através do marido, a personagem descansa de toda e qualquer obrigação reflexiva ou necessidade de conquistar sua própria identidade. Seu mundo fecha-se dentro de uma relação de dependência, apontada por Beauvoir como um caminho pelo qual a mulher permanece em posição secundária, de um ser que só existe a partir de um outro, geralmente o marido, os filhos ou a família. Assim, ela será, nas palavras da filósofa um "être relatif", para o qual a existência se justifica como um prosseguimento do outro, em quem ela justifica seus dias, fechando os olhos para si, entrega-se a uma vida doméstica, acostumando-se a ser a segunda pessoa do casal. Conforme Beauvoir:

\footnotetext{
${ }^{112}$ Assim, o trabalho que a mulher executa no interior do lar não lhe confere autonomia; não é diretamente útil à coletividade, não desemboca no futuro, não produz nada. Só adquire seu sentido e sua dignidade se é integrado a existências que se ultrapassam para a sociedade, na produção ou na ação: isto significa que, longe de libertar a matrona, esse trabalho a coloca na dependência do marido e dos filhos; é através deles que ela se justifica: em suas vidas ela é apenas uma mediação inessencial.
} 
II n'est pas permis à la femme de faire une oeuvre positive et par conséquent de se faire connaître comme une personne achevée. Si respecter soit-elle, elle est subordonnée, secondaire, parasite. La lourde malédiction qui pèse sur elle, c'est que le sens même de son existence n'est pas entre ses mains. ${ }^{113}$ (BEAUVOIR, 1949, vol. II, p. 277)

A figura do marido, como é comum na obra juditiana, é também a de um antagonista de Alma, pois se trata de "um homem apagado, sem ninguém, vinte anos mais velho" (AERNA, p. 24), ele vive entre os muros de sua limitação, pondo em dúvida tudo que ultrapasse o provável. Todavia, ainda assim é o condutor da mulher rumo a um mundo resumido ao espaço da casa grande e vazia. Ironicamente, na narrativa de Maria Judite, Hermes vive preso em estreitos muros, onde só cabem suas certezas em tudo aquilo que pode ser provado, contrariando a mitologia que liga seu nome ao sábio mensageiro de Zeus ${ }^{114}$.

O narrador contribui para a construção negativa do homem, não nos poupando de suas reflexões e afirmações recortadas e de suas frases, feitas com tom de quem tem a receita da vida real:

Hermes não acreditava no homem. E como ao longo de uma existência de isolado poucos homens conhecera bem, que lhe permitissem um tal julgamento, sem dúvida precipitado, bastavam-lhe dois, que eram sempre, falasse do que se falasse, os seus exemplos: o patrão e Valdemar aquém tinha salvo a vida. (AERNA, p. 24)

Ao nos apresentar as demais personagens ou quando antecipa os fatos, a voz do narrador dentro do texto vai construindo as informações de maneira equisciente ${ }^{115}$, a descrição da alienação doméstica à qual Alma está sujeita é construída de maneira

\footnotetext{
${ }^{113}$ Não é permitido à mulher fazer uma obra positiva e, por conseguinte fazer-se reconhecer como pessoa acabada. Por respeitada que seja é subordinada, secundária, parasita. A grave maldição que pesa sobre ela está em que o sentido mesmo de sua existência não se encontra em suas mãos.

${ }^{114}$ Vale lembrar que na mitologia greco-romana Hermes é considerado mensageiro e condutor, quem direciona as almas para o reino dos mortos, podendo também trazê-las de volta ao mundo dos vivos. Não por acaso, no enredo juditiano é o marido que terá direito de escolher se a mulher passará ou não pela cirurgia que lhe dará nova aparência.

${ }^{115}$ Usamos aqui a relação entre narrador e personagem mencionada por Oscar Tacca, segundo o qual as informações podem ser fornecidas pelo narrador de maneira onisciente, equisciente ou deficiente. Ver TACCA, Oscar. As vozes do romance. Trad. M. Gouveia. Coimbra: Almedina, 1983.
} 
crua, mas ao mesmo tempo cuidadosa, exemplificando a fina ironia do narrador juditiano. Ao nos apresentar as falas de Hermes, deixa-nos o julgamento de que não passam de induções ingênuas para definir o ser humano entre mau ou bom. Quando a mesma voz nos conta que a mulher tem no marido o exemplo de coerência, temos a exata medida do estado alienador no qual o casamento a colocou.

A narrativa não tem um final definido e ficamos sem saber de fato o que será do destino da protagonista. Se Alma chegará ou não a saber da proposta feita pelo médico ao seu marido e se ela seguirá, diante do espelho, pensando em como seria "se sofresse" uma "transformação", através das mágicas mãos do doutor Valdemar. Nada é confirmado, no entanto, a voz narradora nos deixa alguns indícios de que a mulher jamais saberá da oferta que o médico fizera ao marido, pois no momento em que nos comunica do encontro casual entre os dois colegas, o narrador antecipa ao leitor que aquele "encontro, porém, ficaria no domínio um pouco vago das coisas semiirreais" (AERNA, p. 26).

A frase acima pode ser entendida como uma negação da possibilidade de escolha para a mulher e o destino que a espera é o de um sofrimento sem solução. A infelicidade de início permanece e o conto finda com a protagonista a mirar-se no espelho, no mesmo estado de angústia que a acompanhara por todos os seus dias, deixando a narrativa com um aspecto de circularidade e o destino da protagonista como um mal sem cura.

É sem dúvida muito marcante a presença do espelho no enredo, pois é o meio revelador através do qual a protagonista pode estar diante das fragilidades do cotidiano e das relações sociais, de uma face que parece sua oponente. Além de ser importante, o espelho exerce também um papel ambíguo no jogo do enredo juditiano, é o denunciador da imagem "desoladora, mas ao mesmo tempo reconfortante" (AERNA, p. 23). Quando está diante de si, a personagem permanece longos minutos a fitar-se como se procurasse algo que não está visível. Tal busca pode ser explicada pelo conceito de olhar de Marilena Chauí, para quem "o visível está povoado de invisíveis a ver e que, vidente, é aquele que enxerga no visível sinais invisíveis aos nossos olhos profanos" (CHAUÍ, 1988, p. 33). 
O olhar tem um destaque importante enquanto sentido dominador do ouvir, do falar e até do sentir o mundo. Enquanto ação reveladora, o ato de ver pode ser o caminho da auto-revelação e de um descobrir o mundo. A busca de si mesmo pelo olhar é então o princípio da quebra da construção das ilusões, sendo essa última, a característica de um caminho para explicar a estagnação de Alma. Podemos dizer que o fato de olhar-se diante do espelho em determinados momentos permite que a personagem construa um olhar que quebre as próprias ilusões, pois a mesma inquietase diante da própria realidade como se quisesse corrigi-la. Ou conforme Chauí: "a ilusão carrega a promessa de uma visão verdadeira que corrige a ilusória, desde que corrijamos nosso ponto de vista". (CHAUÍ, 1988, p. 33).

Alma divaga e imagina como tudo poderia ser diferente se ela fosse bonita, até mesmo seu nome poderia soar diferente, mas ela se torna cada vez mais inerte, aceitando a impossibilidade de mudar a própria realidade. Amargura-se com a crueza do que the mostra o espelho, já que o objeto transforma-se em denunciador da sua condição o resultado de tal confronto é um ar melancólico diante da idéia de falência tão comum às mulheres juditianas. Ainda nas palavras de Chauí, mirar-se diante do espelho é conhecer determinados pontos e atingir zonas de perigo no próprio interior e conflitos ainda sem solução. Como exemplo a filósofa cita o fato de alguns povos indígenas se recusarem ao espelho, "pois sabem que a imagem refletida é sua própria alma e que a perderão se nela e nele depositarem o olhar" (CHAUÍ, 1988, p. 35).

O espelho é também o objeto de sedução do olhar, nele estão contidas as ilusões que amenizam o estado de infelicidade da protagonista. Alma tortura-se diante de seu "demônio mudo", para transgredir com a realidade ao seu redor. Sublima as próprias insatisfações, numa espécie de fuga, de troca de mundos, deixando de lado, por momentos, as tormentas e lançando mão de uma vida imaginária, construída na divagação de "se eu fosse bonita". Ao fazê-lo a mesma consegue vencer a falta de expectativas de seu cotidiano e o substitui pela imagem que gostaria de ter de sua exsitência. Esta troca de realidades se explica nas palavras de Chauí, já mencionadas no início do trabalho: "Porque cremos que a visão se faz em nós pelo fora, olhar, ao mesmo tempo, sair de si, e trazer o mundo para dentro de si" (1988, p. 33). 
As narrativas analisadas possuem particularidades expressas em suas personagens, seja de conduta ou de reflexão, que nos remeterão também para a necessidade do ver-vendo-se, uma situação constante para as protagonistas de uma e de outra narrativa, que estão sempre em busca por um eu para além da existência exterior. Há nos enredos a ameaça constante de um estado latente, que se acomoda à sombra do cotidiano: a solidão. É importante, no entanto, observar que existem inúmeras diferenças na construção do olhar no universo das personagens, Ana e Alma, embora a conseqüência deste olhar produza efeito parecido na existência dessas personagens.

O ver-se é ponto sinalizador para a inquietude que as tira do estado comum em que antes viviam, trazendo à tona a reflexão sobre o submeter-se ao papel social, anulando os desejos e subjugando a liberdade ao destino. A imagem que têm sobre si mesmas é produzida de maneira oposta, já que Alma tem consciência sobre seu estado de passividade e domesticação quando está diante do espelho, este, na condição de luz que reflete. Enquanto Ana reage diante desta representação quando é confrontada com o escuro, semelhante ao cego, que tateia na escuridão é que a leva ao seu (des)caminho.

É esse momento de tomada de consciência que desencadeia os atos transgressivos, e aqui nos referimos a um transgredir sem rupturas de fato ao estabelecido, sem deixar de manter certa ligação com as relações sociais e seus determinados papéis. Segundo Geoges Bataille "A transgressão organizada forma com o interdito um conjunto que define a vida social (...) como um movimento de diástole completa um movimento de sístole"116 e qualquer movimento para fora disso pode se chamar de rompimento.

É de nosso interesse o ponto de vista de Bataille, também pela vertente que define a transgressão como um rompimento com a própria condição do indivíduo e, transpondo tal conceito para o universo das personagens em questão, é possível afirmar que a "transgressão organizada" é um processo parecido ao que ocorre com Ana e Alma. A primeira rompe com o espaço doméstico e durante algumas horas vive sua revolução, mas sem romper jamais com o papel que tão bem exerce. Já a

\footnotetext{
${ }^{116}$ BATAILLE, Georges. “A transgressão”. In O erotismo. Porto Alegre, L\&PM Editores, 1987, p. 61.
} 
personagem juditiana vive apenas no ensaio de uma transgressão assistida, imaginase com outra aparência, porém não consegue romper o forte espaço da casa. As duas protagonistas ainda que quebrem o invólucro das obrigações sociais, a elas se conformam seja por desejo ou por destino.

As personagens dos contos possuem diferentes posições dentro do espaço social. Ana consegue romper, mesmo por instantes, toda a conduta a ela destinada e perde-se entre os labirintos do Jardim Botânico, e numa caminhada com aspectos de catarse, ela vai se reencontrando e consegue quebrar mesmo por instantes sua domesticação, a ocupação com a casa e a família se perde na imensidão do jardim. Enquanto que Alma não consegue romper os muros da casa e continua a carregar os pesos de sua existência, pois dentro de seu estreito mundo tudo era apenas como um "silêncio que ela às vezes sentia necessidade de afastar de si" (AERNA, p. 22).

A passividade que envolve, em doses diferentes, a vida das duas personagens está sempre a ponto de se partir, para Ana havia as horas perigosas das quais era preciso fugir: "Sua precaução reduzia-se a tomar cuidado na hora perigosa da tarde, quando a casa estava vazia sem precisar mais dela" (A, p. 31). Para Alma o espelho era o momento de reflexão, de sair da realidade cuidadosamente inventada para chegar à real: "Era uma visão desoladora, mas ao mesmo tempo reconfortante" (AERNA, p. 23).

As duas protagonistas precisam criar proteções para o que está latente nas entrelinhas dos enredos: a explosão perigosa de uma existência em conflito por não caber em si, por descobrir-se em meio à falência da própria condição, e também pela necessidade de buscar uma completude nunca alcançada, e ao mesmo tempo temida:

Minha condição é muito pequena. Sinto-me constrangida. A ponto de que seria inútil ter mais liberdade: minha condição não me deixaria fazer uso da liberdade. (...) A condição não se cura, mas o medo da condição é curável. (LISPECTOR, 1994, p. 169)

O silêncio será uma das marcas do papel assumido pelas duas personagens, Ana e Alma são donas-de-casa, mulheres que casaram para levar uma vida de dedicação ao outro, sempre existindo em relação ao marido e ao lar. A maneira como 
são explorados o papel social e a submissão das duas personagens nos leva a ver também a interpretação da sociedade da época feita por Clarice Lispector e Maria Judite de Carvalho, assim como a preocupação das autoras em denunciar a condição feminina e suas penas.

A personagem juditiana sofre mais agressivamente o confinamento e a ausência de vida social, todos os momentos do conto são limitados ao espaço da casa, sua trajetória se dá entre a sala, o quarto e o espelho, seu único momento de evasão. Alma não vive o mundo para fora do ambiente doméstico, recebe o que vem de fora pelos jornais e pelo marido, habituou-se a abrir os olhos no escuro, e foi escolhida por Hermes por ser "sossegada e pouco exigente", mantendo-se sempre da mesma maneira para merecer seu posto de mulher casada, seu poder se limita a casa, enquanto que a rua é dominada apenas pelo marido, assim se estabelecem as relações de poder.

A partir da ascensão da burguesia e do aparecimento da sociedade industrial e do capitalismo, começou a se firmar a idéia de que a mulher deveria viver confinada ao lar, e seu papel reduziu-se ao de mãe e esposa. Segundo Rocha-Coutinho esse confinamento está ligado ao ideal de família pregado pelo amor romântico, concebendo a mulher como ser frágil cujo homem deveria manter longe do perigo, e poupar de assuntos como sexo e outros considerados ou "muito difíceis" ou "proibidos". Esta concepção contribuiu para que a mulher tomasse para si a personalidade de frágil e indefesa, como nos explica Rocha-Coutinho:

É assim que, com o novo regime, se consolida o discurso da 'natureza feminina'- frágil, emotiva, dependente, instintivamente maternal e sexualmente passiva -, instalando-se o 'lugar feminino' de esposa e mãe centrada no espaço doméstico. (ROCHA-COUTINHO, 1994, p. 31)

A relação com o espaço revela um dos principais pontos de diferença entre Ana e Alma, no enredo clariceano a primeira cena mostra-nos a personagem em mobilidade, ela está dentro de um bonde, ao avistar o cego é como se a realidade se alterasse, ela fecha os olhos para um cotidiano limitado e abre para a imensidão do jardim. É o escuro que aguça o olhar das duas mulheres, Ana tem sua visão ampliada 
através da escuridão do cego, enquanto que Alma utiliza a estratégia de ficar "de olhos abertos no escuro", a imaginar-se bonita, escapa assim de seu cotidiano doméstico. $E$ sua única chance de mudança real é logo anulada pelo marido, que diz ao amigo cirurgião que talvez a mulher não tenha ambições de beleza:

Hermes agradeceu, disse que não dava a certeza porque ela talvez não quisesse. Sentia-se feliz assim, porque não se sentiria se ele gostava dela? As pessoas habituam-se, de resto, a si próprias, à sua própria cara. Mudar para quê? (AERNA, p. 29)

A casa é o principal espaço de confinamento para essas mulheres, porém este espaço é ainda mais agravante para Alma. Diferente de Ana, ela não rompe as paredes da casa, não tem seu momento de errância e a única revolução que ocorre em seu cotidiano vem da tristeza que sente pela limitação da aparência, pela sonoridade passiva e apagada do nome, mas nenhum ato se segue a essa constatação, a passividade da personagem juditiana é total. Prisioneira de si mesma ela nada tenta contra a própria domesticação. Ao passo que Ana tem seu dia de rompimento, é bem certo que retorna para seu lugar nos afazeres da casa, mas com a chama acesa que não se apagará mais. Além do mais romper os muros e se deixar levar pelo espaço público é a transgressão de Ana que a coloca para além de Alma, pois segundo Rocha-Coutinho, até os anos de 1970 a conquista do espaço público era destinada apenas aos homens e significava, portanto, interdição para o feminino:

Aos homens passa a caber o espaço público da produção, das grandes decisões e do poder, e às mulheres é, então, atribuída a responsabilidade da reprodução, em todas as suas formas, no seio da família. Seu trabalho como 'reprodutora' é naturalizado, cabendo a ela a execução e a supervisão de uma série de tarefas conhecidas como 'trabalho doméstico' que se realizam no âmbito da unidade familiar. (ROCHA-COUTINHO, 1994, p. 33)

O trabalho doméstico é para as protagonistas o dever diário e a ajuda para se manterem distantes do perigo, evadir-se no cotidiano é uma das maneiras de fugir de si, das reflexões e questionamentos, cumprir plenamente o papel social que limita o feminino à execução de tarefas repetidas e sem reconhecimento algum da sociedade. 
Como antes fora mencionado, as donas-de-casa serão de fato trabalhadoras sem jamais serem reconhecidas pelas novas leis trabalhistas surgidas com o capitalismo, havendo também o fato de que as tarefas domésticas impedem ou dificultam a participação da mulher no espaço público sendo mais uma peça de alienação social.

É na divisão entre público e privado que o espaço será de fundamental importância no tocante à abordagem do universo feminino e sua condição, portanto segregar a mulher em casa liga-se diretamente ao princípio da opressão sobre ela exercida. Rocha-Coutinho defende que o fato de ser atribuído à mulher o espaço privado é um agravante para sua passividade social e seu lugar à margem.

Ao espaço privado foi determinado como domínio da mulher por ela estar destinada à afetividade, ao calor da família, por isso. A casa também é o lugar para aqueles que não possuem nenhum envolvimento social, ficando "a inteligência e a eficácia no exercício do poder no mundo público", que é destinado ao homem. Esta é também, segundo Rocha-Coutinho uma forma de dominação e de passividade social, pois como nos referimos acima o esforço da mulher nas tarefas da casa nunca teve o reconhecimento como contribuição social, resumindo-se a um empenho gratuito e involuntário.

A superficialidade e o perigo das tarefas desenvolvidas no lar são temas das abordagens de Simone de Beauvoir, segundo a qual uma das maiores ameaças à mulher após o casamento seriam os afazeres domésticos sempre desenvolvidos no espaço interno, em total solidão e sem representar nenhuma contribuição social, excluindo essa mulher de qualquer possibilidade de participação nas atividades que conduzem o mundo exterior:

Il faut donc que le produit du travail ménager se consomme; une constante renonciation est exigée de la femme dont les opérations ne s'achèvent que par leur destruition. Pour qu'elle y consente sans regret, du moins faut il que ces menus holocautes allument quelque parte une joie, un plaisir. Mais comme le travail ménager s'epuise à maintenir un statu quo, le mari en rentrant chez lui remarque le désordre et la 
négligence mais il lui semble que l'ordre et le propreté vont de soi ${ }^{117}$. (BEAUVOIR, 1949, vol. II, p. 275)

No âmbito dos contos das escritoras, ora analisadas, a denúncia do trabalho doméstico como alienação e segregação da mulher é freqüente. Podemos apontar vários casos, tanto no universo clariceano, como na escrita juditiana, nos quais as mulheres fogem de seus malogros através de tais práticas. Em "A fuga", conto do início da carreira de Clarice, somos colocados em meio a uma tarde de desordem no cotidiano de Elvira, domesticada em um casamento de doze anos e que

Vive atrás de uma janela, olhando pelos vidros a estação das chuvas cobrir a do sol, depois tornar o verão e ainda as chuvas de novo. Os desejos são fantasmas que se diluem mal se acende a lâmpada do bom senso. (LISPECTOR, 2000, p. 72)

Durante uma chuva que ameaça sua tarde silenciosa de dona-de-casa, ela sente o peso dos anos e da reclusão doméstica lhe incomodarem, então rasga as roupas, rompendo com o espaço e decide sair, partir deixando para trás o papel de mulher casada para ser apenas uma mulher livre a olhar o mundo para fora dos limites da janela.

Os instantes em que ela passa a andar pelas ruas, planejando fugir em um navio para longe, são os fios com os quais tece seu destino, em uma tentativa de desconstruir o papel social de mulher domesticada e sem autonomia sobre si mesma. Habituada aos dias talhados por um cotidiano sem surpresas, a personagem assustase com a imensidão das ruas e suas possibilidades e tem medo de não tocar o fundo daquele mar de possibilidades que é fugir, quebrando assim a domesticação.

O medo a faz voltar e, angustiada consigo mesma, ela retoma seu lugar sem desarrumar a vida exterior, porém seu interior está totalmente deslocado e a sua domesticação certamente não será mais a mesma. A conseqüência será a dor de ter aceitado a própria condição e o peso de sua submissão, que de repente se tornam

\footnotetext{
${ }^{117}$ É preciso, portanto, que o fruto do trabalho doméstico se consuma; uma renúncia constante é exigida da mulher, cujas operações só terminam com a destruição. Para que ela consinta nisso sem lamentá-lo, é preciso pelo menos que esses pequenos holocaustos acendam, em algum lugar uma alegria, um prazer. Mas como o trabalho doméstico esgota na manutenção de um status quo, o marido ao voltar para casa observa a desordem e a negligência, mas parece-lhe que a ordem e a limpeza são naturais.
} 
bem mais visíveis para ela, pois conforme as palavras da própria personagem: "Sim, doze anos pesam como chumbo. Os dias se derretem, fundem-se e formam um só bloco, uma grande âncora. E a pessoa está perdida" (LISPECTOR, 2000, p. 73).

A saída do ambiente doméstico tanto de Ana como da personagem de "A fuga", é uma ruptura importante, sobretudo no que diz respeito à condição na qual vivem essas mulheres. Quando ganham as ruas cada uma reflete a sua realidade em nova perspectiva e para fora das regras às quais se acostumaram a seguir. $O$ resultado é uma visão amplificada em que as cenas do mundo ganham nova proporção, às vezes assustadora, que incita a reflexão e o questionamento do papel social dessas mulheres. Após retornarem, elas não caminham mais na mesma legião, se apegam à vida que escolheram, mas com plena consciência do lugar que ocupam, pois o obsevaram de fora, do espaço público da rua, onde tudo é possível:

Mesmo as coisas que existiam antes do acontecimento estavam agora de sobreaviso, tinham um ar mais hostil, perecível...O mundo se tornara de novo um mal-estar (...) Expulsa de seus próprios dias, parecia-lhe que as pessoas da rua eram periclitantes, que se mantinham por um mínimo equilíbrio à tona da escuridão. (A, p. 33)

Diferentemente do que ocorre às personagens clariceanas, Alma não rompe o espaço da casa, sua domesticação é total e a única maneira de evadir-se é a imaginação, sonhando ser uma outra mulher, com aparência e realidade diferentes. Sua passividade é total diante da condição em que vive, pois nem mesmo o trabalho doméstico recebe sua dedicação. O narrador não faz nenhuma referência ao envolvimento da personagem com tais tarefas, e a única motivação que presenciamos dá-se no momento em que o marido se encontra com o cirurgião e a mulher vê nisso uma esperança que logo combate como se fosse um delírio ao qual não tinha direito, então se repreende e substitui o seu sonho pelo bom senso do marido. Nas palavras do narrador:

Foi ao quarto, viu-se no espelho. Que coisa estúpida lhe passara de repente pela cabeça! A de que aquele homem poderia...Não é verdade? Que loucura a sua. O marido tinha razão, como sempre. Enfim, como a maioria das vezes. Deus pusera no mundo gente cheia 
de defeitos e ordenara a toda essa gente que se amasse. (AERNA, $p$. 29)

A figura representada pela personagem juditiana enquadra-se no modelo de dona-de-casa que se dedica unicamente ao marido, sem ter no mundo um lugar para existir. O quadro do relacionamento de Alma com o marido Hermes pode adequar-se muito bem àquele descrito por Beauvoir, através do qual a mulher coloca-se no lugar de obediência e respeito àquele que faz as leis:

Mais après tout, y a voir clair ce n'est pas son affaire: on lui a enseigné à accepter l'autorité masculine; elle renonce donc à critiquer, à examiner et juger pour son compte. Elle s'en remet à caste superieure. C'est pourquoi le monde masculin lui apparaît une realité transcendente, un absolu ${ }^{118}$.(BEAUVOIR, 1949, vol. II, p. 481)

No universo juditiano a devoção ao outro pode tornar-se degradante ou mesmo perigosa, como acontece com a protagonista de "O homem voador e a mulher que não tinha asas". Já em seu título a narrativa indica as diferenças entre um e outro, ou seja, entre a condição feminina e a masculina no universo narrativo. "Amélia, calma e respeitada burguesa de uma pequena cidade da província", vê nos trapézios um jovem voando pelos ares. A personagem então larga "tudo, casa, família, para seguir o trapezista no seu rumo incerto" (OHV, p. 75).

A sua falta de costume para a liberdade, a sua ausência de asas, fazem a personagem chocar-se com os vôos do homem. O medo de vê-lo morrer estatelado no chão se torna obsessivo. Um dia Amélia se depara refletindo sobre a vida, pensando o que fizera de sua existência "segura" para acompanhar a incerteza do outro e, a partir desse momento, o homem passa de marido a ser amado, parte necessária que ela não poderia ver cair dos ares, como ela mesma caíra de sua vida:

Pesou-lhe sobre os ombros e sobre o peito. Que fizera da sua vida? Que fizera de si, mulher de sua casa, respeitada por todos, com uma filha pequenina? Que loucura tinha sido aquela? (OHV, p. 77)

\footnotetext{
${ }^{118}$ Afinal, ver com clareza isso tudo não é de sua alçada: ensinaram-lhe a aceitar a autoridade masculina; renuncia pois a criticar, a examinar, a julgar por sua conta. Confia na casta superior. Eis porquê o mundo masculino se apresenta a ela como uma realidade transcendente, um absoluto.
} 
Ao ver-se para fora de sua vida, sem um lugar para si junto daquele homem que ganhava a vida com acrobacias, Amélia não suporta o estado de exílio e a transgressão que cometera pondo fim a sua posição de respeito. Deixara seu papel de dona-de-casa, e não havia outro para ocupar ao lado de um homem que escolhera. A liberdade dele a incomoda profundamente, deixando-a com "o coração imenso e inquieto, quase a asfixiá-la" e só a morte do homem pode trazê-la de novo a paz perdida. Após assassiná-lo ela se sente "subitamente calma" e com um sorriso que denunciava o desequilíbrio:

Foi presa mais tarde e internada num manicómio. Os psiquiatras consideraram-na Luca. A casa onde estava era-lhe porém indiferente. Dormia horas e horas e tinha nos lábios um sorriso tranqüilo. Gostava de conversar com as outras mulheres e passava dias a contar-Ihes as proezas de Karl-o-Homem-Voador. (OHV, p. 80)

O doloroso trajeto da protagonista juditiana exemplifica o ponto extremo de dependência e submissão ao outro e o medo da incerteza que estavam presentes em muitos casamentos das mulheres acostumadas a uma domesticação "segura", na qual era proibido ter asas. Esta limitação era uma conseqüência da organização social e do casamento, condicionando a mulher ao espaço do lar e à dependência total do homem:

On enferme la femme dans une cuisine ou dans un boudoir, et on s'etonne que son horizon soit borné; on lui coupe les ailes, et on déplore qu'elle ne sache pas voler. Qu'on lui ouvre l'avenir, elle ne sera plus obligée de s'installer dans le présent. ${ }^{119}$ (BEAUVOIR, 1949, vol. II, p. 487)

Amélia temia um futuro sem o outro por quem cometera tal "loucura", e como ela não havia construído um lugar para si, seria impossível a vida sozinha. O martírio de prever a dor da solidão a cada dia torna-se obsessão e a leva à ruptura com sua submissão em relação ao homem. O choque do ato violento causa a mudança de

\footnotetext{
${ }^{119}$ Fecham a mulher em uma cozinha ou em um budoar e se espantam que seu horizonte seja limitado; cortam-lhe as asas e lamentam que não saiba voar. Que lhe abram o futuro e ela não será mais obrigada a instalar-se no presente.
} 
comportamento da personagem e o sentimento de deslocamento e exílio a leva ao delírio, no rompimento total com a realidade.

Ao contrário de Amélia, é a posição ocupada ao lado de um homem e o dever com as coisas que se repetem que fazem Ana abandonar o Jardim Botânico a tempo de sobreviver e agarrar-se de novo aos filhos e à calmaria de seu papel de dona-decasa. Há, nos vários perfis de mulheres traçados por Lispector e por Maria Judite, o questionamento e muitas vezes a reconstrução do papel da mulher que foi domesticada pelo casamento.

O choque com um cotidiano angustiante e o estado reflexivo pelo qual são tomadas as personagens são pontos de partida para repensar a condição de desfavorecimento que tem sido ocupada pela mulher. A repetição de tarefas solitárias, a dependência de um homem, ou os deveres a cumprir, formam os "blocos de concreto que pesam como chumbo" (LISPECTOR, 2000, p.74) e que contribuem para tornar a vida dessas mulheres a cada dia mais sufocante.

Para aquelas que vivem e se dedicam inteiramente ao espaço da domesticação, o homem ganha as proporções de herói, senhor e protetor de suas vidas. Mas se porventura essa imagem se quebra toda a existência dessas mulheres pode ser totalmente abalada; é o que acontece com a protagonista de Armários vazios. Dora Rosário perde o marido e passa a viver imersa em suas recordações e, alheia ao mundo a seu redor, já que não encontra mais lugar para si, ela se abriga em um espaço entre a vida que tinha com o homem e a que precisa levar para conduzir as rédeas de si mesma:

Quando o marido morreu e ela soube que ele estava perdido, foi como se a terra ruísse a sua volta e só o pedacinho de chão onde tinha os pés estivesse ficado quieto. O mundo ao redor, já de si pouco habitado, e mal, estava subitamente deserto. Com a chegada de Duarte operarase não uma adição mas uma total substituição de interesses. (CARVALHO, 1966, p. 24)

Pouco tempo depois da morte do marido Dora descobre que fora traída durante anos e que antes de cair enfermo de morte o marido planejava deixá-la, resultando numa indignação que faz o universo de luto e tristeza desabar em ruínas. Ela intenta se livrar do papel de "viúva inconsolável" e muda radicalmente a aparência 
apagada de sempre, substituindo as vestes de dona-de-casa recatada e triste por trajes de alguém passível de aventuras. Mas tudo isso vinha certamente acompanhado de uma grande melancolia e do sofrimento de sentir-se ainda mais humilhada diante da traição e da rejeição do outro, como podemos destacar nas palavras do narrador:

Era um pesadelo e ela ia acordar, queria acordar e dar com tudo bem arrumado nos mesmos lugares: a imagem de Duarte, a sua situação de viúva inconsolável, aqueles momentos em que voluntariamente chamava o marido, tudo isso. Mas de repente não havia nada senão uma mulher mais enganada do que qualquer outra, enganada para além da morte, durante dez anos.(CARVALHO, 1966, p. 43)

Obrigada a quebrar toda a imagem que durante anos construíra do marido, Dora sofre a dor de quebrar a imagem de conduta exemplar que construíra do marido a mulher que surge após sua catarse é alguém triste e intensamente amargurada, que tenta disfarçar na aparência seus anos de submissão e engano.

É importante observar em relação à protagonista da novela juditiana, que suas práticas serão sempre a conseqüência de uma atitude tomada por causa ou para o outro. A personagem não existe por si mesma, até quando tenta valorizar seu aspecto físico o faz por uma tentativa de vingança do homem que a traía. Essa subserviência faz parte, segundo Beauvoir, do papel que a mulher assume ao casar, pois além da interdição aos grupos sociais, ela alicerça suas emoções, convicções e realizações nas de seu marido, assumindo o papel para o qual fora ensinada:

Pour elles la pensée est plutôt un jeu qu'un instrument, même intelligentes, sensibles, sincères, elles ne savent pas, faute de techiniique intellectuelle, démontrer leurs opinions et en tirer les conséquences. C'est par là qu'un mari - même beaucoup médiocre prendra facilement barre sur elles; il saura prouver qu'il a raison, même s'il a tort. ${ }^{120}$ (BEAUVOIR, 1949, vol. II, p. 291)

\footnotetext{
${ }^{120}$ Para elas, o pensamento é antes um jogo do que um instrumento; mesmo inteligentes, sensíveis, sinceras, elas não sabem, por falta de técnica intelectual, demonstrar suas opiniões, tirar as conseqüências que comportem. É por esse lado que um marido - mesmo mais medíocre - as dominará facilmente: saberá provar que tem razão, ainda que não tenha.
} 
A filósofa defende que seja na família ou no casamento, a mulher está sempre condenada ao cuidado com o outro, a servir, o que a destina mais fortemente aos trabalhos da casa que são sempre motivados pela tentativa de agradar ao outro, este referindo-se ao pai, irmão ou marido. Desta forma, podemos dizer que ela terá sempre um homem para cuidar e, em troca, receber deste a proteção que the garantiria o respeito perante a sociedade. Destacamos também que o cuidado que recebe se intensifica conforme a fragilidade e a ingenuidade demonstradas por ela. Tal característica da personagem pode explicar o comportamento submisso não apenas de Dora, mas de todas as personagens acima relacionadas.

Como acima já citamos, a domesticação do feminino não se justifica ou se constrói por um aspecto natural ou biológico, mas é configurado pelo meio social no qual a mulher cresce e se desenvolve. Nos anos 60, ou até mesmo em tempos posteriores, essa construção social vendia o casamento como meio único e respeitável de ascensão social para a mulher, não importando sua classe. Sob este aspecto, destacamos as palavras de Beauvoir:

Dans certains milieux burgeois, on laisse encore la jeune fille incapable de gagner sa vie, elle ne peut que végéter en parasite au foyer paternel ou accepter dans um foyer étranger quelque position subalterne. Même dans le cas où elle est plus émancipée, le privilège économique détenu pour les mâles l'angage à préférer le mariage a un métier ${ }^{121}$ (BEAUVOIR, 1949, vol. II, p. 225)

O que justifica o fato de mesmo com todos seus pontos negativos, o casamento pode ser considerado como um dos grandes alvos da mulher, algo acima de uma carreira ou da liberdade que poderia comprometer sua reputação para sempre. A melhor maneira para evitar esses riscos era o casamento, não esquecendo que a situação conjugal representava um benefício mais considerável para a esposa do que para o marido, deixando-a ainda mais inserida na condição de refém e obrigada a renunciar à liberdade ou à carreira em prol de uma suposta "segurança matrimonial":

\footnotetext{
${ }^{121}$ Em certos meios burgueses ainda se deixa a moça na incapacidade de ganhar a vida; ela só pode vegetar como um parasita no lar paterno ou aceitar uma posição subalterna em algum lar estranho. Mesmo nos casos em que ela é mais emancipada, o privilégio econômico detido pelos homens a incita a preferir o casamento a uma profissão.
} 
Cependant, en même temps qu'elle le désire, la jeune fille souvent redoute le mariage. II represente um bénéfice plus considérable pour elle que pour l'homme, et c'est pouquoi elle le souhaite plus avidement; mais il exige aussi de plus lour sacrifices; en particulier, il implique une rupture beaucoup plus brutale avec le passé. ${ }^{122}$ (BEAUVOIR, 1949, vol. II, p. 230).

\footnotetext{
${ }^{122}$ Entretanto, ao mesmo tempo que o deseja, a moça teme o casamento. Este representa um benefício mais considerável para ela do que para o homem, e é por isso que ela o deseja avidamente; mas exige também pesados sacrifícios: em particular implica uma ruptura muito mais brutal com o passado.
} 


\section{As idas e vindas: mulheres fugitivas}

Vou desaparecer de você para sempre. Te amo como nunca. Adeus. Tua Angela não foi mais tua porque você não quis.

Clarice Lispector

No presente capítulo trataremos de algumas personagens femininas de Clarice e Maria Judite que fogem para sobreviver, partem por não suportar a realidade, ou ainda para construir um espaço possível. Através da comparação entre os contos "O búfalo" e "Adelaide" das respectivas escritoras, traremos à análise várias referências às protagonistas que sustentam o tema da fuga nas diferentes maneiras em que ele se apresenta nos cenários brasileiro e português.

Observando que o desejo de partir e o de buscar além de si uma possibilidade de existência, é também o estado de quem vive em exílio ou se sente à margem, e de quem se confronta com uma condição desfavorável em relação aos demais. Esse será um esboço dessa mulher que nos anos de 1960 teria de ser refugiada de si mesma e do mundo em volta para se apropriar do direito a conduzir o próprio destino, e assim obter um espaço "todo seu", como argumentou anos antes Virginia Woolf.

\subsection{0 esboço de uma ira}

Eu ainda não sei controlar meu ódio, mas sei que meu ódio é um amor irrealizado, meu ódio é uma vida ainda nunca vivida. Pois vivi tudo - menos a vida.

Clarice Lispector

Aparentemente a trama que envolve o enredo de "O búfalo", conto que fecha o livro Laços de família, pode ser classificada como descomplicada: uma mulher que vai ao jardim zoológico para o exercício de aprender a odiar com os bichos. Porém quando acompanhamos a protagonista logo vemos que a aparente simplicidade será uma das falsas ilusões injetadas pelo narrador. A primeira cena nos coloca diante da mulher que, de punhos serrados dentro dos bolsos, começa sua procura entre as 
jaulas, assim nos é apresentada a protagonista. Em seguida vemos que nesse cenário, cercada pela surpresa de olhar a cada momento um ser diferente, a mulher começa o caminho rumo à tentativa de cumprir sua missão que é a de odiar o homem por quem foi rejeitada:

Com os punhos nos bolsos do casaco, olhou em torno de si, rodeada pelas jaulas, enjauladas pelas jaulas fechadas. Continuou a andar. Os olhos estavam tão concentrados na procura que sua vista às vezes se escurecia num sono, e então ela se refazia como na frescura de uma cova. (OB, p. 157)

Quanto mais caminha entre os bichos, mais se depara com sua incapacidade para o ódio. Então segue compondo com o olhar uma imagem particular de cada animal observado. O primeiro é o leão, no qual ela busca o ódio de fera, mas encontra o animal iluminado pela ternura vinda do pós-ato amoroso com a fêmea. Em seguida se coloca diante da girafa "que mais era paisagem que um ente". A personagem, então, sente-se cercada pela doçura da qual é preciso fugir e a insistência da face sensível do animal a distancia cada vez mais do vestígio do ódio para o qual ela não fora criada "Pois havia tal amor humilde em se manter apenas carne, tal doce martírio em não saber pensar" (OB, p. 158).

A tentativa de indignar-se é repetida a cada bicho observado. Seu olhar se depara com os macacos a se divertirem como crianças, e ainda há "a macaca com olhar resignado de amor" (OB, p. 158). Os movimentos lúdicos dos animais misturamse à singeleza diante dos olhos da mulher, resultando em efeito oposto ao inicialmente buscado. De repente ela se sente observada por um macaco preso às grades como um Cristo crucificado e a primeira vontade da protagonista é de assassiná-lo, disparando um tiro entre seus olhos. No entanto percebemos que o narrador nos havia enganado, juntamente com a personagem, numa ilusão de ótica, pois o olhar descrito era apenas um jogo e o velho macaco era cego, era uma criatura tão doente quanto ela:

De repente a mulher desviou o rosto: e que os olhos do macaco tinham um véu branco gelatinoso cobrindo a pupila, nos olhos a doçura da 
doença, era um macaco velho - a mulher desviou o rosto, trancando entre os dentes um sentimento que ela não viera buscar (OB, p. 158).

A observação de cada bicho a aproxima de si mesma, da confirmação de que não havia nela a revolta necessária, então o desejo de ódio vai se frustrando na lamentação e na angústia por não possuir em si a força para devorar o outro, eliminálo com fúria de mulher rejeitada, mas tudo que via tinha a imagem de primavera e afeto. O sentimento de angústia se reforça ainda mais quando ela se detém diante da quase imensidão do elefante, mas era uma "potência que se deixaria docilmente conduzir a um circo" (OB, p. 159).

A protagonista avança e observa os "grandes cílios empoeirados do camelo", a sua herança de paciência milenar acabava se contrapondo à ansiedade que ela tinha em odiar. A protagonista a partir de então se fecha, enjaulada em sua incapacidade de encontrar o sentimento que buscava: "Lágrimas encheram os olhos da mulher, lágrimas que não correram, presas na paciência de sua carne herdada" (OB, p. 159).

Como se tivesse desistido de buscar seu ódio entre os bichos, a mulher caminha para a montanha russa, episódio que será o marco que dividirá o conto em dois momentos. A mudança de direção representará um último recurso pelo qual a personagem abandona a busca entre os animais e arrisca para o alto como tentativa de alcançar sozinha a violência desejada.

A subida opera na personagem uma espécie de redenção, senta-se sozinha, separada como se em uma igreja, e após ser levada ao alto renasce para depois morrer, como se por instantes tivesse permanecido em outro mundo, de onde era possível ver toda a sua vida ampliada pela altura, ou ainda exprimir seu desespero misturando ao barulho dos outros a denúncia de seu abandono: "Ela que poderia ter aproveitado o grito dos ouros para dar seu urro de lamento, ela se esqueceu, ela só teve espanto" (OB, p. 161). Volta em silêncio, mas com seu mundo à revelia, ela foi sacudida pelo choque de ver tudo de tão longe: "Pálida, jogada fora de uma igreja, olhou a terra imóvel de onde partira e onde de novo fora entregue" (OB, p. 161). 
Mesmo sentindo-se abandonada e tentando construir o ódio pelo homem que a abandonara, havia na personagem uma herança para o amor funcionando como interdição ao desejo de irar-se. Ela tinha o hábito de deixar-se conduzir pelo caminho de amar, não sabia como indignar-se contra o desprezo do outro, restando-lhe apenas a tentativa de aprender com os bichos. A vertigem na montanha russa será a quebra na trajetória da sua busca, causada pelo choque de sentir seu corpo lançado na "alegria de um novo mergulho no ar" e, no supetão do movimento involuntário, ela se sente ainda mais perdida, como se sua vida se revelasse diante de todos:

Não olhava para ninguém. Contrita como no dia em que no meio de todo mundo tudo o que tinha na bolsa caíra no chão e tudo o que tivera valor enquanto secreto na bolsa, ao ser exposto na poeira da rua revelara uma vida íntima de precauções (...) ela recolhendo do meio-fio os andaimes de sua vida. (OB, p. 161)

Após a catarse ocorrida na montanha russa, a mulher tenta continuar seu caminho em busca do ódio, porém, nesse momento, opera-se uma mudança de plano em sua trajetória. Ao colocar novamente a protagonista diante das jaulas, o narrador faz uma espécie de troca de posições, ou melhor, de papéis, e ela passa a ser observada pelos animais. Encosta-se à jaula do quati e confunde-se com as grades como se fosse ela a enjaulada, enquanto o bicho a observa. Seu lugar parece contrário ao da perspectiva anterior: "A testa estava tão encostada às grades que por um instante lhe pareceu que ela estava enjaulada e que um quati livre a examinava" (OB, p. 162).

Ao ver-se como aprisionada a protagonista quase atinge o ódio desejado, sente nas grades geladas junto a seu rosto a força que precisava para matar o homem aos poucos dentro de si, uma violência indecifrável toma conta dela e "a fêmea rejeitada espiritualiza-se na grande esperança." (OB, p. 162). Retoma sua busca em meio aos bichos, ela havia reforçado seu desejo de encontrar o caminho, deixar de amar e perdoar. A personagem precisava revoltar-se contra sua existência passiva: 
Recomeçou então a andar, agora apequenada, dura, os punhos de novo fortificados nos bolsos, a assassina incógnita, e tudo estava preso no seu peito. No peito que só sabia resignar-se, que só sabia suportar, só sabia pedir perdão, só sabia perdoar (OB, p. 163)

Como se agora ela evitasse ver, fecha os olhos prendendo a cabeça entre as grades e tentando uma "passagem impossível", mas logo se deixa vencer pela exaustão de morte que a leva ao seu confronto final: os olhos do búfalo. Mas há um contraste entre o corpo enegrecido do animal e uma brancura intensa que inunda a mulher, como se fosse uma tentativa de anular a força que começava a se produzir dentro dela: "Uma brancura espalhara-se dentro dela, branca como papel, fraca como papel, intensa como uma brancura" (OB, p. 166).

O negro do pelo do animal parece inundá-la para ir, aos poucos, se transformando no ódio do qual ela necessitava. O momento se intensifica e ela sente naqueles olhos a força da ira buscada:

Sua força ainda estava presa entre barras, mas uma coisa incompreensível e quente, enfim incompreensível, acontecia, uma coisa como uma alegria sentida na boca. Então o búfalo voltou-se para ela. O búfalo voltou-se, imobilizou-se, e, à distância, encarou-a.

(OB, p. 167)

Com os olhos fixos no búfalo e os punhos serrados no bolso do casaco, ela é observada e se inunda da profundidade do olhar com o qual é atingida. Podemos dizer que a força dos olhos negros do animal é o fio condutor de sua perdição. Abandonando o próprio corpo a personagem se deixa cair em vertigem e o instante final do conto concentra-se no efeito do olhar do animal sobre quem a mulher atira o ódio que deveria ter pelo homem: "Eu te amo, disse ela então com ódio para o homem cujo grande crime impunível era o de não querê-la. Eu te odeio, disse implorando amor ao búfalo" (OB, p. 167).

O momento final do conto nos mostra a intensidade da mágoa e do desespero que acompanham a protagonista, então ela se vê obrigada a transformar em ira um sentimento de frustração. A condição de "fêmea desprezada" traduz a situação de abandono em que a mulher se encontra, tornando-a presa fácil do 
homem e do animal que a mirava: Inocente, curiosa, entrando cada vez mais fundo dentro daqueles olhos que sem pressa a fitavam, ingênua, num suspiro de sono, sem querer nem poder fugir, presa ao mútuo assassinato. (OB, p. 167).

Como estivesse ferida pelo olhar que a atravessara ela se entrega à uma intensa vertigem e vê "o céu inteiro e um búfalo" (OB, p.168). O olhar é uma das características mais marcantes do enredo, é através dele que a protagonista se dirige aos bichos para depois retornar a si, além de que suas ações partem sempre de um desejo de ver/sentir: colocar-se diante de algo como tentativa de se misturar ao que é visto.

Os olhos são o instrumento principal que a protagonista utiliza em sua busca pelo ódio. O olhar é também um modo de falar, de dar sua dor em troca do ódio que esperava aprender com os bichos, de soltar o grito preso pela condição de desvantagem diante do homem. O desejo da personagem é expresso pelo corpo, nos olhos, nas mãos serradas no bolso do casaco.

A representação do conflito interior através do corpo nos remete ao ensaio de Yannick Resch, referente à significação do corpo na escritura de autoria feminina. Dentro de tal temática, os olhos são importantes na relação dominador e dominado, pois: "La domination pour le regard qui est généralement attribuée à la femme est décrite différemment suivant que ce pouvoir décrit ou non un code compréhensible"123.

A análise de Resch refere-se às personagens da escritora francesa Collete, mas para isso constrói um retrato das protagonistas e da importância que vão gradativamente ganhando na escritura de autoria de mulheres do século XX. É por esse motivo que as características apontadas por seu estudo, salvaguardando algumas diferenças, bem podem ser aplicadas às personagens clariceanas, sobretudo no que diz respeito à valorização do corpo como forma de comunicar-se no texto. É o que vemos na protagonista de "O búfalo", pois é através dos olhos que ela grita sua angústia e procura uma consciência reflexiva a parir da observação dos bichos.

${ }^{123}$ A dominação pelo olhar que geralmente é atribuída à mulher é descrita diferentemente segundo o poder de tornar descritível ou não um código compreensível. RESCH, Yannick. Corps féminin, corps textuel: essai sur lê personnage féminin dans l'oeuvre de Collete. Paris : Librairie C. Klincksieeck, 1973, p. 58. 
Os verbos ver e observar se espalham por todo o conto, assim como as diversas perspectivas do olhar pois, como já nos referimos acima, na primeira parte do conto a personagem observa profundamente os bichos mas não é notada por nenhum deles. A protagonista, como podemos observar, passa de jaula em jaula comparando o comportamento de cada animal, buscando fios que a levem ao ódio, porém é ignorada por todos os alvos de sua observação. Somente na segunda parte da narrativa é que o olhar se inverte e ela então é primeiro observada pelo quati e ambos se confundem como em uma troca de posição, na qual é a mulher que se torna a enjaulada.

Sua tentativa de fugir para a revolta e de protestar contra o próprio destino frustra-se esbarrando nas paredes do seu mundo e na "mesquinharia de uma vida íntima de precauções"(OB, p. 163), em uma existência quebrada, da qual era preciso juntar os cacos. É já quando sua peregrinação começa a chegar ao fim que ela se depara com o animal que lhe transmitirá o ódio necessário para a morte, um búfalo ameaçador cujos imensos olhos capturam toda a disposição pro amor que havia nela, ele a ensinaria "a ler o seu próprio ódio" e assim livrar-se do risco de morrer de amor, de escravizar-se ao outro:

Onde aprender a odiar para não morrer de amor? E Com quem? O mundo de primavera, o mundo das bestas que na primavera se cristalizam em patas que arranham mas não dói...oh não mais esse mundo! (OB, p. 163).

O confronto com o búfalo ocorre no momento final do conto, após a mulher passar pela vertigem da montanha russa, então sua perspectiva em relação aos animais é outra, haja vista estar presa entre as grades de sua busca. Sua respiração se dificulta a condição de rejeitada a aperta como uma camisa-de-força, então, sua visão se aguça e seus olhos se encontram com os do imenso animal. Os olhos vermelhos do búfalo despertam os sentidos da protagonista e ela sente o sangue negro correndo-lhe por dentro, a força das duas cores vermelho e negro vão contrastar com o branco da vertigem diante dos seus olhos. Podemos acrescentar 
que cada cor apresenta-se carregada de significado, como se traduzissem o estado de alma da personagem, o que se explica nas palavras de Resch:

La plus parte du temps la couleur a une signification psychologique. Elle est utilisée comme procede permettant d'exprimer à travers une image concrète, une émotion, un sentiment ou une réaction.(RESCH, 1973, p. $54)^{124}$.

A fuga da personagem vem também pelo olhar as nuvens brancas que cobrem o céu. Os seus olhos buscam ainda atingir o ódio: "Sua cabeça ergueu-se em indagação para as árvores de brotos nascendo, os olhos viram as pequenas nuvens brancas" (OB, p. 164). È possível concluir que a trajetória da busca, assim como a fuga da mulher abandonada, vai se traduzir em todas as suas etapas através do olhar, seja por seu formato, ou pela cor que ele assume ao final do conto.

Os olhos atentos em busca do ódio, assim como o olhar de redenção no momento em que a montanha russa a leva pelos ares, ou ainda os olhos que se negam a ver e escondem-se na brancura do silêncio da personagem. Os diferentes momentos do enredo retratados nos olhos da protagonista traduzem toda a sua dor de fêmea rejeitada, como nas palavras de Resch: "à travers des qualifications du regard, en particulier en ce qui concerne la couleur, un code qui renouvelle et révèle les relations des femmes et des hommes en tant que dominant / dominé» ${ }^{125}$ (RESCH, 1973, p. 60).

As emoções contidas provocam o efeito contrário das sensações desejadas pela personagem, já que o ódio e a raiva buscados deparam-se com os olhos dóceis do leão no momento do cio ou até mesmo a revolta do grito buscado na montanha russa transforma-se em redenção. O choque com o oposto dá-se nessa tentativa de construir na destruição, ou ainda na consciência dela, como nos explica Nadia Gotlib ${ }^{126}$, a autora desconstrói para construir, chega à fragilidade da mulher pelo seu contrário, pois é o desejo de ser forte, de revoltar-se e de odiar o outro que nos

\footnotetext{
${ }^{124}$ Em grande parte das vezes, a cor tem uma significação psicológica. Ela pode ser utilizada como meio que permite exprimir através de uma imagem concreta uma emoção, um sentimento ou uma reação.

${ }^{125}$ através das qualificações do olho (ou do olhar), em particular a que diz respeito a cor, um código que renova e que revela as relações da mulher e do homem como dominante/dominado.

${ }^{126}$ Nos referimos ao texto "Une apprendissage des sens" publicado na edição especial dedicada a Clarice Lispector da revista canadense Études Françaises, 1989 (ver referência completa na bibliografia final).
} 
mostra a submissão e a passividade da mulher em relação ao homem que a abandonara.

\subsection{Paisagens sem ilhas}

O conto "Adelaide", de Maria Judite de Carvalho, é uma narrativa curta sobre alguns instantes decisivos e angustiantes na vida de uma mulher chamada Adelaide, que vê suas emoções aniquiladas por acreditar em demasia em um homem. No presente enredo, como no conto de Lispector, também temos uma narrativa alinear, cujo início é uma das últimas cenas do enredo na qual podemos sentir a frieza do homem, assim como a ingenuidade de Adelaide que a fizera chegar a uma situação de extrema humilhação:

Nessa altura ainda ela não tremia nem chorava nem sentia medo. Tudo isso viria depois, misturado com um claro desejo de morrer e um obscuro medo de procurar a morte (A, p. 83).

Após esta primeira imagem o narrador nos mostra como se construiu a cena acima e nos dá pistas do que viria depois. Em seguida a narrativa retrocede alguns dias e vemos que Adelaide vivia, a princípio, sem questionar sua condição de dependência e afastamento do mundo "como quem não compreendia". Uma mulher que havia passado das mãos do pai para as de um marido, acarretando-lhe uma ingenuidade que a fazia presa fácil:

Ela, porém, não sabia. Fazia uma vida muito retirada e o marido fora buscá-la à província. Não conhecia, pois, esses jogos elegantes. A mãe era tão burguesa que ignorava mesmo o que era ser burguesa. Por isso tudo ela o fitava boquiaberta. (A, p. 86)

A protagonista é construída pelo narrador ocupando o papel de uma mulher casada com um marido indiferente à sua solidão e que jamais consegue percebê-la ou entender seus sentimentos e desejos ingênuos, como o de um dia partir em busca de ilhas distantes. Adelaide fechava-se dentro de ilusões e constrangia-se diante da 
própria ingenuidade, resultando na necessidade de se perdoar diante de si e dos outros. Ela por vezes ficava "envergonhada talvez das próprias limitações ou da mediocridade da sua vida" (A, p. 85), e vivia como exilada, para fora de seu mundo.

A necessidade de construir para si uma realidade que fugisse do mundo do casamento e da incompreensão em que vivia, são fatores que contribuem para que Adelaide pense sua felicidade sempre em terras distantes de onde vive. $O$ tempo de sua quase felicidade começa em uma festa, na ocasião Adelaide é deixada de lado pelo marido e entregue ao acaso. De repente se dá conta da presença de um homem disposto a dispensar-Ihe alguma atenção, então nasce a esperança de ser notada por alguém.

Tinha nessa noite um ar de rapariguinha atrasada. Pouco bonita, pouco elegante e certamente pouco esperta. O marido parecia muito interessado na loira de vestido verde e absolutamente indiferente ao facto de a mulher estar ali, a três metros de distância. (A, p. 85)

É o "ar de rapariguinha atrasada", que motivará o homem a se aproximar do lugar vazio ao lado da mulher, e ela em sua ingenuidade sente-se vingada do marido que está a cortejar uma outra. Após esse encontro inicial surgem algumas perguntas sobre viagens e demais assuntos, aos quais ela se mostra sempre alheia, até que ele possa descobrir a matéria dos sonhos de Adelaide e então formular as promessas de levá-la às sonhadas ilhas dos mares do sul, desencadeando uma série de esperanças infundadas:

\footnotetext{
"A bem dizer, não sei. Nunca sai daqui. Suponho que deve ser agradável. E adorava viajar. Sabe o que gostava imenso de conhecer, o meu sonho?"

"As ilhas dos mares do Sul?"

Tinha-o olhado, boquiaberta.

"Meu Deus, como adivinhou?" (A, p. 85)
}

A rápida conversa estabelecida entre eles desenha um quadro do estado de ilusão em que vive a personagem, habituada a esconder-se atrás da imagem de eterna criança, ela não criara senso de valores ou leis próprias de sua personalidade; a postura de Adelaide tem a forte presença da ingenuidade, um recurso algumas 
vezes assumido no mundo feminino como forma de afirmar a submissão. Todo o quadro amoroso que ela desenhara com o desconhecido não passava de uma coincidência e um desejo deste de passar um pouco o tempo fazendo-lhe promessas:

Porque dissera aquilo? Por que o marido estava ali a fazer a corte a outra mulher? Por que ela tinha tudo da presa fácil? Por que tivera pena da sua solidão? Sim, por tudo isso mas principalmente porque houvera uma cadeira vazia a seu lado. (A, p. 86)

A vida de Adelaide se passa como se a ela não coubesse definir meios ou fins, sendo melhor deixar esta função aos homens, seu perfil está entre o das mulheres que preferem destinar ao homem as decisões e atitudes mais complexas, dedicando-se às repetições de um cotidiano superficial, como nos explica Beauvoir:

Non seulement elle ignore ce qu'est une véritable action, capable de changer la face du monde, mais elle est perdue au milieu de ce monde comme au coeur d'une immense et confuse nébuleuse. Elle sait mal se servir de la logique masculine. ${ }^{127}$ (BEAUVOIR, 1949, vol. II, p. 480).

Adelaide habita em um mundo em que a reflexão perde lugar para o sonho. Como uma vida construída à revelia do real, sua existência não caminha ligada a objetivos. Suas convicções vêm daquilo que escuta do marido, absorvendo, deste modo, tudo que a ela chega, por mais contraditório que possa parecer. Sua relação com a sociedade se constrói através do outro, assim ela segue em toda a narrativa como em uma repetição do que escuta.

$\mathrm{Na}$ maneira como a protagonista apreende a realidade, o homem adquire o status de um deus a quem convém seguir e, sobremaneira obedecer, assim Adelaide representa a mulher ensinada a aceitar a autoridade masculina. Tal posição leva a protagonista a crer facilmente em promessas e, assim, se tornar mais suscetível a ilusões. Desta forma então elle renonce donc à critiquer, à examiner et juger pour son compte (BEAUVOIR, 1949, vol. II, 481).

\footnotetext{
${ }^{127}$ Não somente ela ignora o que seja uma verdadeira ação, capaz de mudar a face do mundo, mas ainda perde-se no meio desse mundo como no centro de uma imensa e confusa nebulosa. Sabe servir-se mal da lógica masculina.
} 
Após algumas palavras ditas ao ingênuo ouvido de Adelaide, o homem adquire a categoria de "herói", cuja a missão seria a de levá-la em um vôo para longe daquela "vida muito retirada" a que de fato ela não mais queria pertencer. Era uma mulher simples a quem o marido tinha ido buscar em uma "distante província", não seria difícil conduzi-la rumo à ilusão por ela buscada, fazendo o outro se sentir à vontade para criar as fantasias e depositar aos ouvidos ingênuos de Adelaide toda sorte de palavras enganosas:

Ele então, ao vê-la assim tão vulnerável ao seu lado, julgara que sim, que era verdade, que gostava dela (...) Dissera-lhe então muitas coisas, coisas tão loucas que nenhuma mulher iria acreditar totalmente nelas. Nenhuma mulher a exceção de Adelaide. (A, p. 86)

Uma das conseqüências da ingenuidade feminina, segundo Beauvoir, é a crença. Sua capacidade de crer pode se aplicar a todas as áreas da vida. $O$ misticismo feminino direciona-se principalmente ao que diz respeito aos homens e, como exemplo, poderíamos lembrar das mulheres que na Idade Média usavam de todas as crenças para ajudar seus guerreiros ${ }^{128}$, seguindo rituais e práticas que se relacionavam a seu gosto pela repetição. Em nenhum momento a personagem de Maria Judite de Carvalho pensa em questionar as promessas do homem, pois sua crença estava bem mais nas próprias ilusões do que nas palavras que ouvia.

As copiosas juras pelo telefone a deixavam cada dia mais surpresa com "a sorte" que julgava ter. Porém o narrador denuncia o absurdo das promessas feitas pelo homem e a banalidade com a qual o mesmo divertia-se com o desejo de ilusão de Adelaide: "Dissera-Ihe então muitas coisas, coisas tão loucas que nenhuma mulher iria acreditar totalmente nelas. Nenhuma mulher à excepção de Adelaide" (A, p. 86).

Depois de alguns dias de repetidas conversas ao telefone, ela parte rumo à casa de seu "salvador". Contrariando, porém, os seus planos, encontra alguém frio e indiferente às suas ilusões. O momento da fuga torna-se também o instante de quebra, e Adelaide percebe a fragilidade de uma falsa esperança, a protagonista é relançada à sua realidade e se encontra "oscilante, como que vergada ao peso dos

\footnotetext{
${ }^{128}$ Ver a esse respeito O sexo dos textos, de Isabel Allegro de Magalhães, citado na bibliografia do presente trabalho.
} 
longos cabelos, ou da mala, ou da dor" (A, p. 83) e coloca-se, perante o homem, em estado de choque por ver todas as suas ilusões ruírem diante de seus olhos.

Não havia para onde voltar, pois antes de partir ela confessara tudo ao marido e, diante dessa lembrança, então um "claro desejo de morrer e um obscuro medo de procurar a morte" (p. 87) a fazem sair sem rumo. O choque da ilusão quebrada é como um espelho partido, eliminando em seus estilhaços a máscara de mulher ingênua, para compor no lugar uma outra face. Parecendo "outra mulher, ela sai em silêncio, sem rumo a seguir, como uma fugitiva, humilhada por ter a sua tentativa de transgressão reprimida pelo homem, perdida nas falsas esperanças criadas. Ela

Não tinha havido uma recriminação, um lamento, uma lágrima a molhar-lhe a voz. Parecia outra mulher e era isso que ele dificilmente podia perdoar-lhe.

Vira-a dobrar-se um pouco, pegar na mala, vergar outra vez ao seu peso - ao seu peso? -, depois vira-a voltar-se e sair, digna e sem palavras (A, p. 87).

Ao sair sem rumo e com sua bagagem de sonhos, Adelaide deseja morrer, contudo pesa-lhe o medo que a impede de suicidar-se. Ela segue um caminho não de retorno, pois nesse universo o tempo não volta e as situações são retomadas apenas pela memória. Por isso o narrador nos coloca pistas de que Adelaide pode chegar à morte, se a tristeza, aos poucos, ultrapassar o medo.

Como não pode voltar para o marido, a quem confessara sua fuga, sem destino a seguir, a sua imagem assemelha-se a de "Uma pobre formiga carregada com os seus haveres mas sem buraco para onde ir" (A, p. 88). Resta-lhe trilhar sua via crucis sem uma vereda determinada, pois ela continuará seguindo sem rumo, fazendo com que a narrativa não tenha um final definido e a busca da personagem se prolonga para além das páginas do texto, cabendo ao leitor finalizar conforme as suas próprias impressões de leitura.

Adelaide parte e leva consigo apenas a mala e a própria vida, onde nada havia sido criado por ela, tudo acontecera pelas mãos dos outros, em especial pela mão do marido que se esquecera dela, e depois pela mão do homem que em tantas 
coisas a fez crer. E como ela não conhecia os "jogos elegantes" da sociedade, tornouse alvo de um simples acaso sendo, de repente, forçada a criar o próprio destino, transgredindo a si mesma e a sua cômoda condição de mulher casada.

Em seguida chegamos à conclusão de que Adelaide fugia de fato, não para encontrar o homem, mas para exilar-se de si mesma. Esta dedução será um dos pontos de aproximação entre Adelaide e a protagonista de "O búfalo", anteriormente exposta. Além do fato marcante de as duas serem mulheres rejeitadas e que necessitam fugir para não se perderem.

São histórias próximas, salvaguardando as devidas diferenças, pois no primeiro enredo, a mulher tenta partilhar com os animais a sua angústia de fêmea desprezada e ferida pela indiferença do homem. Sua trajetória não mostra alguma possibilidade de volta, nem de alguém que a espere ou a aceite novamente e o único caminho possível é a morte. Já Adelaide segue a esmo, sem sabermos que caminho tomará, transformada pela angústia e a humilhação.

Podemos dizer que um destino de malogros é outro ponto de aproximação entre essas duas personagens, pois enquanto a primeira sente-se "enjaulada" por não conseguir odiar o homem que a humilhara, a segunda é rejeitada por um desconhecido que a faz ver sua ilusão de terras distantes resumir-se a uma rua cheia de carros entre os quais ela marcha como formiga. Nas duas narrativas vemos mulheres fugitivas, imersas na ilusão de exilarem de uma realidade insuportável, de uma rejeição e de uma condição aprisionadoras.

A falta de um sentimento forte que a mova também é um dos percalços de Adelaide que. Mesmo humilhada, ofendida, fracassada em sua fuga e rejeitada pelo outro, não consegue nutrir ódio ou nenhum outro sentimento que a mova. As duas personagens são mulheres entregues a uma servidão e submissas. A protagonista juditiana mostra uma ausência de vitalidade e de amor próprio, diminui-se diante do marido e dos outros homens. Lou Andréas-Salomé em ensaio sobre as relações amorosas nos explica: 
O amor dos homens, por mais ilimitado que seja, necessita do apoio de um robusto amor-próprio para poder extrair do tesouro de riquezas individuais, que sem dúvida possui, aquilo que pode dar aos outros ${ }^{129}$.

A personagem clariceana também esbarra em seus próprios muros ao tentar irar-se, revoltar-se contra o homem a quem ama, mas no momento em que se confronta com a força e a soberania do búfalo, ela desfalece. Este resultado reforça seu estado de submissão, e sua vertigem pode traduzir-se na dificuldade de continuar sua busca. Tal situação ocorre, segundo Salomé, pela impossibilidade de fugir dos próprios muros:

É sempre contra nossos muros que esbarramos, e é em cima deles que aperfeiçoamos nossa imagem do mundo, mesmo que nos afastemos o máximo possível dos outros, mesmo quando aí empilhemos tudo aquilo que é nosso. (SALOMÉ, 2005, p. 15).

Mesmo procurando refugiar-se dentro do zoo, a mulher leva consigo toda a carga de servidão e por isso não consegue a violência com a qual busca odiar aquele que a rejeita. Adelaide estanca no limiar da porta do homem em quem decidira acreditar, ali ouve toda sorte de humilhações, mas isso não produz nela nem mesmo uma expressão de raiva. Sabemos pela voz narradora que algo em si mudou, que ela não é mais a mesma mulher, mas sua submissão não lhe permite expressar isso, tal como a protagonista de Lispector, a personagem juditiana também não possui a capacidade da revolta.

Mesmo sob o efeito que o homem nelas causara, essas mulheres não conseguem libertar-se totalmente de sua condição, e seu estado de dominadas interdita para elas o amor do outro. A protagonista de "O búfalo" foge para tentar assassinar dentro de si o homem a quem não conseguira atingir com seu amor. Ela tenta conter "o desejo que o indivíduo tem de se apossar na totalidade, da vida que o rodeia, de entrar nela, de ser preenchido por ela" (SALOMÉ, 2005, p. 16).

O sentimento amoroso parece interditado no universo das duas protagonistas, pois o homem é o antagonista contra o qual ambas tentam lutar e o

\footnotetext{
${ }^{129}$ ANDREAS-SALOMÉ, Lou. Reflexões sobre o problema do amor e O erotismo. Trad. Antonio Daniel Abreu. São Paulo: Landy Editora, 2005, p. 14.
} 
abandono será o resultado dessa interdição. Até então temos pontos de semelhanças, no entanto é importante observar as diferenças existentes em cada situação.

A cena do conto clariceano nos coloca diante de uma mulher com desejo de vingar-se. Mas a ausência do sentimento de ódio impossibilita 0 ato, a rejeição e o abandono a fazem querer a raiva pelo homem amado, entretanto o que vamos conhecendo é sua falta de jeito para chegar a outra margem do amor: "Eu te odeio', disse ela para um homem cujo crime único era o de não amá-la. 'Eu te odeio', disse muito apressada. Mas não sabia sequer como se fazia" (OB, p. 159).

Sua marcha por entre os bichos não leva ao sentimento desejado, mas produz algo positivo: o auto-conhecimento, a sua morte pela dor, a sua redenção pelo choque e a catarse na montanha russa, são todas situações que colaboram para que a protagonista chegue a si mesma e entenda-se em sua capacidade de amar e deixe assim as vestes de abandono com as quais entrara no zoológico.

No conto "Triunfo", Lispector nos apresenta um percurso parecido ao da mulher no zoológico, Luisa se vê em total submissão ao homem com quem mora, até que ele a abandona e o confronto com o sofrimento e a solidão a aproximam também de si mesma, aguçando seus sentidos e sua percepção do mundo que estava esquecido em seus olhos:

Ela estava só, desde a sua partida. Tinham brigado. Ela, calada, defronte dele. Ele, o intelectual fino e superior, vociferando, acusandoa, apontando-a com o dedo. E aquela sensação já experimentada das outras vezes em que brigavam: se ele for embora, eu morro, eu morro. (LISPECTOR, 2005, p. 12)

Ao se deparar com a solidão, Luisa observa de novo o espaço a sua volta e de repente é posta para fora do estado de cegueira no qual o outro a deixara e então se surpreende por conseguir desvendar a falsa figura de intelectual e soberano que ela construíra para o homem. O estado de aparente desespero de Luisa transformase em triunfo quando ela se dá conta que o homem que a abandonara era medíocre e que a sua superioridade era algo que ela criara para submeter-se a ele. 
De repente ela sente o mundo de novo possível a sua volta e percebe que "as coisas não estavam de todo destituídas de encanto". Temos então um caso de ascensão pela dor. A catarse sofrida após o confronto com a solidão é o preço para chegar a si mesma. A ausência do homem a faz refletir, ver e descobrir-se através do outro que, muitas vezes, serve para o auto-conhecimento pode também bloqueá-lo. Durante um banho frio, a angústia de Luisa torna-se alívio, um quase prazer, e a partida do outro afirma a confiança de que ela poderia sobreviver à sua partida: "Riu. Ele voltaria, porque ela era a mais forte" (LISPECTOR, 2005, p. 15).

Voltando ao universo das protagonistas em questão, tanto Adelaide como a personagem claricenana, buscam chegar a si pelo outro. O homem é o caminho para o eu dessas mulheres, mas a possível paixão se frustra. Então o inverso do amor deveria aflorar nas duas mulheres. Em Adelaide por ter sido humilhada no mais profundo de seus sentimentos e, na mulher do zoológico, pelo fato de ter sido abandonada e frustrada em seu desejo de ser amada.

O que observamos no universo dessas mulheres, no entanto, é que o outro é apenas um caminho para si mesmas e que a aparente intensidade de um amor acaba geralmente se desfazendo diante do choque e da reflexão que a ele se segue. O ser amado como caminho para descobrir-se é explicado por Salomé como meio de chegar ao familiar pelo estranho:

O entusiasmo que se apodera de nós no amor a nenhum outro é comparável. É desencadeado pelo próprio fato de um ser novo, estranho (pressentido talvez e antecipadamente desejado, mas nunca apreendido na realidade), nos dar um primeiro impulso - que não provem dos meios formados pelos conhecidos e familiares, nos quais a muito nos fundimos, e que são apenas o nosso reflexo. (SALOMÉ, 2005, p. 16)

Vemos então que o amor dessas mulheres não é um encontro, mas uma busca por agarrar-se ao oposto. Ver-se no outro, não é chegar a um determinado ponto de realização, e sim estar próximo, daí estas personagens com seus amores fadados ao desencontro e à fuga, tendo como conseqüência o fatídico encontro consigo mesmas. Portanto, a busca pela raiva ou desejo de vingança tem como 
resposta a ausência de sentimento, pois as personagens não ultrapassam o amor a ponto de chegar ao seu oposto: o ódio.

É no viés dos amores mal fadados e da condição na qual se encontram que podemos analisar a ilusão da fuga empreitada pelas duas protagonistas. Fugir é um ato muito recorrente para as personagens clariceanas, já no universo de Maria Judite esse é um tema que não ocorre com tanta freqüência, mas nos momentos em que o encontramos é possível observar que apresentam uma construção bem próxima a que é feita pela escritora brasileira. Para as personagens da escritora portuguesa, fugir é sempre um sem-rumo, mas também sem volta. Não existe um retorno possível e por isso algumas vezes a fuga tem como destino a morte.

Ao descrever a marcha de Adelaide por entre os carros, o narrador nos sugere que ela poderia matar-se, mas que não há coragem para 0 ato, pois a personagem sentiria "um claro desejo de morrer e um obscuro medo de procurar a morte" (A, p. 87). A última imagem que temos da mulher é de alguém sem rumo e perdida como uma espécie menor entre as maiores, seu estado de angústia a deixa suscetível à morte:

Uma pobre formiga carregada com seus haveres mas sem buraco para onde ir. Por isso caminhava tão devagar, por isso não chamava nenhum dos táxis que passavam por ela. Não tinha morada para lhes dar. (A, p. 88)

O conto "O grito", parte do livro Seta despedida, é um bom exemplo do estado de solidão do feminino. Camila é uma professora que mora com um antigo namorado. Tem um cotidiano morno e tenta projetar-se em várias etapas de vida: mãe, escritora, pintora, porém não consegue caminhar dentro de nenhuma delas, já que nada é marcante em sua existência, nem mesmo a expressão do rosto ou a voz, ela é alguém facilmente esquecida nas relações sociais:

Passava despercebida, os outros não a reconheciam logo, tinham que pensar duas vezes, era fácil de perceber. Também esqueciam facilmente o que dizia. Acontecia-Ihe dar uma opinião qualquer, e logo depois, durante a conversa, atribuírem as suas palavras a outra pessoa. (CARVALHO, 1995, p. 112) 
A cada falência consigo e com o outro, ela caminha um pouco mais para dentro de si até sentir-se em total isolamento, "E foi se tornando cada vez mais vazia e mais só". Sua angústia atinge o insuportável e ela reage atirando-se pela janela num exílio final que, se não era a solução, poderia ser a saída para o seu nãopertencimento "E um dia ao acordar sentiu que tinha que ser. Porquê não sabia bem, só que tinha que ser, que não havia outra saída" (CARVALHO, 1995, p. 117).

Em "Carta aberta à família", do livro Flores ao telefone, que será analisado mais à frente, uma mulher casada vive aparentemente tranqüila ao lado de um homem de família tradicional. No entanto havia sido um casamento por medo da solidão e de não ter um lugar para si na sociedade. Com o passar dos anos seu conflito aumenta e a sufoca. Ávida por uma saída, ela decide ceder aos impulsos de uma paixão e fugir passando da condição de mulher casada para forasteira diante da família: "Só mais tarde foi que o problema surgiu, estava casada havia cinco anos. Foi quando me apaixonei. Tive então um gesto pouco hábil que poria contra mim pai, mãe e amigos" (CAF, p. 126).

A vida nova após a separação não se apresenta como aquela que ela buscara, se é possível dizer que alguma outra vida era buscada, sua paixão se dissipa e não compensa a rejeição do filho, com o qual tem direito a passar apenas um domingo por mês. O menino não consegue permanecer ao lado da mãe por muito tempo e se apressa em partir para cumprir os tantos compromissos da família Cercal. Sem saber o que fazer de seus dias e sem rumo, a personagem avista diante de si a morte como única porta por onde prolongar a sua fuga:

Foi no último domingo de Outubro (...), foi nesse domingo de céu cinzento e chuva miúda mas constante, que a ideia, que ainda o não era, me aflorou mais uma vez com a brevidade quase inexistente de um vislumbre. (CAF, p. 121)

As protagonistas juditianas não deixam atrás de si uma possibilidade de volta, as setas despedidas não podem retornar e continuar a viver se torna impossível. Para essas personagens, a fuga atinge quase sempre seu ponto máximo na morte, ou então na partida por um caminho sem volta, tornando-se uma quase morte da 
existência. Há uma enorme dificuldade em confrontar-se com a vida, presente em quase a totalidade das mulheres das narrativas juditianas. José Manoel da Costa Esteves ao debruçar-se sobre o livro Seta despedida enfatiza a importância da solidão das personagens aliada ao desencanto diante da vida:

Esta obra feita em solidão e também feita de solidão, porque as várias vozes narrativas que a percorrem falam sempre desse lugar deserto do desencanto onde o paraíso não tem lugar (como inversamente o não tem o inferno), mas onde brota a fonte da lucidez de um olhar magoado a existência humana e a dificuldade de viver. ${ }^{130}$

A intensa solidão das personagens e a dificuldade de galgar os degraus da vida se juntam à passividade e ao desejo de morte. Esse é o sentimento que melhor pode traduzir o tema da fuga em Maria Judite de Carvalho. Assim acontece com Adelaide, quando o mal-estar por viver enclausurada dentro de si mesma a faz buscar fuga em ilhas distantes, sonhar com viagens ou acreditar que o amor inesperado the trará uma felicidade que de fato não saberia ter, pois apresenta a falta de jeito para a alegrar-se e para ser feliz como as demais personagens juditianas.

Esteves se refere ao conjunto de narrativas reunidas em Seta despedida, destacando ser este o momento em que a escritora amplifica algumas das características já presentes em narrativas anteriores, elevando ao máximo as dores da alma humana e os conflitos nas relações entre as pessoas:

Nunca o abandono, a marginalização afectiva, social e geracional das suas personagens, a desistência até o suicídio, foram tão evidentes (...) Nos doze textos que o compõem insinua-se uma voz murmurada e discreta com um tom desencantado que evidencia a crueldade do homem, a solidão, a desilusão, irreversibilidade do tempo, a incomunicabilidade e a dificuldade de viver. (ESTEVES, 1999, p. 75)

São características que bem podem ser atribuídas tanto ao conto "Adelaide" como também à totalidade de Flores ao telefone. Vemos que no quadro da personagem aqui analisada, o tempo e os atos são irreversíveis, pois Adelaide

\footnotetext{
${ }^{130}$ ESTEVES, José Manuel da Costa. "Seta despedida de Maria Judite de Carvalho: uma forma abreviada sobre a dificuldade de viver". In Les contes em langue portugaise, étude de cas, Centre de Recherche sur les pays lusophones -CREPAL, cahier n. 6. Paris: Presses de la Sorbonne Nouvelle, 1999, p. 70.
} 
constrói sua partida fechando todas as portas atrás de si, o seu desejo de fuga é conseqüência de não trafegar com liberdade dentro de sua condição nem em meio às relações sociais.

O momento da festa, em que se refugia nas palavras ilusórias do outro, traduz seu pedido de socorro e a necessidade de crer que havia uma realidade para além daquela vivida. O mal estar seguido do choque final pelo estado de humilhação e abandono é uma teia emaranhando a personagem de maneira cruel sem lhe permitir alguma possibilidade de continuar, o que bem descreve o retrato da fuga no universo juditiano.

A fuga que marca a protagonista de "O búfalo" se apresenta como um quadro com muitas semelhanças àquele encontrado na obra juditiana, a começar pelo motivo que ocasiona a busca e a tentativa de se refugiar, tão fortes no momento em que a protagonista entra no zoológico. Porém há alguns detalhes marcantes que emprestam uma outra configuração do tema nas narrativas clariceanas. Primeiramente vemos que fugir é para as personagens da ficcionista um recurso bem mais freqüente do que o será na obra da escritora portuguesa. Em seguida é possível observar pontos de diferenciação no que diz respeito ao espaço dessa fuga e sua anatomia.

O conto "A fuga" pode ser visto como exemplo do quadro acima descrito, a narrativa traz desde o título a manifestação de um desejo de ruptura e busca, em que Clarice constrói num enredo não linear, e com um narrador em terceira pessoa, as etapas que, durante uma tarde, levam a protagonista à explosão e à saída de casa na tentativa de um novo destino. A trama se inicia em meio aos devaneios de uma mulher casada há doze anos, que resolve de repente rasgar as roupas e partir sem direção prevista. É através de suas reflexões que vamos desvendando as transformações de um mundo fechado por altos muros, do qual ela fugia:

Começou a ficar escuro e ela teve medo. A chuva caía sem tréguas e as calçadas brilhavam úmidas à luz das lâmpadas. Passavam pessoas de guarda-chuva, impermeável, muito apressadas, os rostos cansados. (LISPECTOR, 1999, p. 71)

Quebrar o "peso" de anos sob a morna proteção do homem é difícil e doloroso, por isso a todo momento há o temos de que algo a leve de volta ao "ponto 
de partida". Acostumada a passar os dias com a paisagem enquadrada na janela, a novidade da rua a assustava e transgredir era um ato perigoso, mas transformador, pois:

Agora que decidira ir embora tudo renascia. Se não estivesse tão confusa, gostaria infinitamente do que pensara ao cabo de duas horas: "Bem, as coisas ainda existem". Sim, simplesmente extraordinária a descoberta. Há doze anos era casada e três horas de liberdade restituíam-na quase inteira a si mesma. (LISPECTOR, 1999, p. 71)

Diante dela havia um mar profundo e de "águas escuras" que dividia sua vida em dois mundos: aquele estreito do qual fazia parte, e outro imenso e distante, onde tudo era incerteza. Como ainda não sabia "Ihe dar um destino", seria expressão de sacrifício tentar fugir daquele que lhe impuseram, no entanto aos poucos a rua a faz sentir-se livre, "um sabor de liberdade há doze anos não sentido" (LISPECTOR, 1999, p. 72).

Durante toda a tarde a mulher vaga pelas ruas, vendo o movimento da vida de uma nova perspectiva, o mundo e sua própria condição são redimensionados entregues a um sem-rumo cheio de liberdade, que a faz sentir que "tudo é lindo e tem encanto". O próximo passo é planejar uma partida construída em falsa esperança, que por isso logo se perde, dando lugar à face mais realista e melancólica da personagem, já consciente de sua falência torna-se inevitável perceber que "tudo isso é mentira. Qual a verdade?" (LISPECTOR, 1999, p. 74).

Após a constatação de que não chegaria ao lugar das respostas procuradas, ela não suporta a falência do mundo diante de si e volta, resolve se restabelecer na calma de um "pijama macio. Mesmo consciente de que levara anos sendo conduzida pelo "bom senso" de um homem cuja função era a de silenciar seus pensamentos levando-a à escuridão da indiferença, seu vôo falha e ela continua a viver "caindo", agora cada vez mais fundo para dentro das imensas paredes de sua condição de mulher à margem.

O retorno marca um ponto de diferenciação entre a trajetória das personagens das duas escritoras. Quando retornam da fuga, as personagens clariceanas não são mais as mesmas que foram, têm uma consciência plena de seu 
estado e a lucidez que foram buscar, ou que as encontrou mesmo sem o desejarem. Será assim com Cristina, protagonista de "Obsessão" ${ }^{131}$, conto pouco referido pela crítica clariceana, mas de grande importância para conhecermos alguns das principais características da obra da ficcionista. Após idas e vindas para encontrar um filósofo e amante que julgara ser sua saída da alienante vida de mulher casada, ela desiste do embate e retoma seu lugar junto ao marido, mas agora já tão fora de sua vida de antes, que não há mais aproximação entre ela e o homem:

Jaime aceitou-me de volta.

Nunca me fez muitas perguntas. Ele desejava sobretudo a paz. Regressamos à antiga vida, embora ele nunca mais se aproximasse inteiramente de mim. Adivinhava-me diferente dele e o meu 'deslize' atemorizava-o, fazia-o respeitar-me. (LISPECTOR, 1999, p. 61)

Podemos também encontrar outros aspectos para a fuga na obra de Lispector, como o que ocorre em "A partida do trem", em que a personagem Angela Pralini foge em um trem para livrar-se da força que o homem exerce sobre ela. Conforme acompanhamos sua reflexão vemos que de fato a mulher foge de si mesma, do estado de submissão que criara: "é que eu precisava fugir de Eduardo, antes que ele me arruinasse totalmente com sua lucidez: lucidez que iluminava demais e crestava tudo" (LISPECTOR, 1999, p. 24).

Ângela não voltará, como uma quase exceção dentre as narrativas clariceanas, ela partirá para uma liberdade que não sabemos de fato se atinge, angustia-se e tenta culpar o outro como a protagonista de "O búfalo", acusa-se também de viver "covardemente ao lado de Eduardo" e só depois de tempos descobrir que "era uma solitária" (LISPECTOR, 1999, p. 26).

Para Angela ou para Cristina a fuga tem como conseqüência a descoberta de si e do outro. São mulheres que admitem ter dado mais força ao homem do que ele realmente possuía, diminuíram-se para que o outro parecesse maior e assim se justificasse a submissão e o lugar de "segundo" ocupado por elas. Essa reação em relação ao outro nos parece ser conseqüência direta da dependência intelectual a qual

\footnotetext{
${ }^{131}$ Para um estudo mais detalhado sobre o referido conto ver Antes do princípio, era o verbo: Uma leitura de A bela e a fera de Clarice Lispector. Dissertação de Mestrado apresentada por nós ao Programa de Pós-Graduação em Teoria Literária, do Departamento de Teoria Literária e Literatura Comparada da Faculdade de Filosofia Letras e Ciências Humanas da Universidade de São Paulo, 2002.
} 
a mulher foi submetida ao longo dos anos. Durante muito tempo foi negado a ela o direito de se educar, ou de participar da intelectualidade que era reservada apenas aos homens. Referindo-se aos anos de 1960, Maria Lucia Rocha-Coutinho argumenta que:

Muito raras eram as mulheres intelectual ou fisicamente talentosas que não tentavam parecer mais "burras" ou mais "fracas" que seus maridos nesta época. Em lugar de crescer no mundo da carreira ou do trabalho fora de casa, as mulheres eram encorajadas a atingir seu status social através das atividades dos maridos. (ROCHA-COUTINHO, 1994, p. 101)

As personagens em fuga encontram-se com a própria capacidade de ir para além do que Ihes determina o homem. Sentem-se mais fortes, mesmo que se mantenham paralisadas diante da vida e dos próprios atos, como ocorre com a protagonista de "O búfalo" ou com Adelaide. As diferentes situações das personagens acima referidas enquadram-se no modelo explicado por Rocha-Coutinho, da mulher que muitas vezes disfarçava sua inteligência para não representar um perigo para o homem. Educar-se deveria ser algo que a fizesse apenas compatível a sustentar conversas de salão, a não envergonhar o círculo de amigos do marido ou família, fora deste panorama o cultivo intelectual era um luxo perigoso do qual as mulheres de boa família deveriam ser afastadas, assim:

Uma carreira era praticamente inconcebível para a mulher nos anos 50 e início dos anos 60 e sua educação, percebida como um luxo, visava principalmente a criar mães melhores, companhias mais agradáveis para seus esposos e melhores companheiras para os maridos com carreiras. (ROCHA-COUTINHO, 1994, p. 101)

Nos dois casos o outro se torna a prisão e fugir é a única saída para voltar a existir fora do espaço da dominação. A própria fuga é que vai produzir nessas mulheres a reflexão sobre o que realmente são, por isso se descobrem fugindo de fato rumo a si mesmas, como nas palavras da própria Clarice:

Na ponta dos pés o salto.

Parece a história de alguém que foi e não voltou - é para lá que eu vou. 
Ou não vou? Vou, sim. E volto para ver como estão as coisas. Se continuam mágicas. Realidade? Eu vos espero. É para lá que eu vou. (LISPECTOR, 1999, p. 70)

Voltando nossos olhos sobre "O búfalo" e os exemplos acima relacionados, vemos que Clarice constrói de maneira diferente a fuga das personagens. É bem verdade que as veredas por onde passam as mulheres são dolorosas, mas os caminhos permitem geralmente o retorno e a morte quase nunca será uma saída para o caos. No entanto a fuga leva a uma trajetória necessária e insubstituível na vida da personagem, seja para as que partem por não suportar, deixando bilhetes de protestos, ou aquelas que partem apenas para tornar a vida possível.

As protagonistas das duas ficcionistas brasileira e portuguesa experimentam a angústia de não ter voz e nem lugar para si, de ter que calar o desejo de gritar, de denunciar sua necessidade de romper com a condição aprisionadora, vencendo o medo da solidão e do abandono. Ainda que os caminhos trilhados tenham como resultado a solidão de sentir-se fora dos pequenos lugares destinados a elas, essas mulheres transgridem com suas fugas o papel social ao qual se deve seguir sem jamais olhar em volta, pois a miopia é a lei dessa dura condição, em que ver será não seguir, eis a transgressão dessas mulheres.

\subsection{Paradas e partidas}

O outro muitas vezes é o caminho para descobrir-se, como vimos nas abordagens feitas acima, mas também pode significar uma ameaça para a personagem que se sente exilada de seu mundo, e então como conseqüência ela fugirá para dentro de si mesma. Esconder-se através das anotações diárias em um caderno é o recurso da protagonista juditiana Saudade, em "Um diário para saudade".

Menina solitária e vítima da fuga da mãe em companhia de outro homem, seu comportamento arredio serve de chacota para as meninas da escola e a faz ser vista como diferente das outras. O que mais ofendia a reclusão de Saudade era a personalidade marcante de Luísa, menina cativante que possuía "olhos imensos, 
luminosos" e era querida por todos na escola, enquanto a protagonista é cruelmente descrita pelo narrador:

A parva em questão, a principal, a mais parva, chamava-se Saudade, um nome ridículo, mas a mãe era muito romântica, fora-o pelo menos. Era uma rapariguinha sorumbática (...) Não tinha mãe e isso via-se à distância (...) na falta de confiança com que encarava tudo e todos (UDPS, p. 93).

A introspecção na qual a menina fecha seu mundo é um dos motivos de sua diferença, ao que se acrescenta a ausência da figura materna e a herança de ser filha de uma fugitiva, mulher sonhadora, que partira para viver uma paixão, deixando atrás de si a "desorganização e o caos, que o marido desejava para sempre esquecer". Os mesmos olhos impiedosos do narrador descrevem a cena da fuga com ironia e crueza:

Um dia, porém, a mãe tinha fugido. Beijara-a muito, apertara-a muito de encontro ao peito, e pedira-lhe que nunca a esquecesse, jurava, jurava? Ela não percebia nada, murmurava baixinho: "Mas mamã...o que tens mamã?" Tinha pegado na mala e lá se fora lavada em lágrimas diferentes das vulgares, lágrimas por assim dizer entusiásticas, criadoras. (UDPS, p. 95)

A rápida cena nos faz ver que desde o nome a menina carrega a marca da ausência e das faltas com as quais convive, não cabe no mundo dos colegas da escola, resguarda-se das amizades e vira alvo de críticas das pessoas "normais". Seu exílio é amenizado na escrita do diário com as páginas trancadas à chave, despertando a curiosidade dos demais. É nelas que ameniza a incômoda convivência com a madrasta, o oposto da mãe, mas da qual Saudade se mantinha afastada:

Aquela mulher, a madrasta era digna e honesta, uma boa mulher, uma dona de casa perfeita, enquanto que a outra, a mãe, a que um dia fugira com um homem e nunca mais dera sinal de si (nem para saber da menina sua filha) era a desorganização e o caos, que o marido desejava para sempre esquecer. (UDPS, p. 93) 
Nos poucos meios que freqüenta, Saudade transita sempre ausente, como uma exilada, a falta da mãe contribui para que tenha a infância quebrada e seu rito de passagem para a idade adulta antecipado. Esse último quadro junta-se a seu destino que desde o início é composto de ausências e angústias a configurar uma existência de passividade diante da vida Ela não consegue estabelecer algum tipo de relação social, esconde-se em uma caixa asfixiante, negando-se ao mundo de restrições cuja representação maior é a figura imponente do pai, do qual a mãe fugira para viver:

O pai era um homem definitivo e sem remissão. Para ele não havia dúvidas e nem problemas insolúveis. A mãe fora cheia deles e encontrara na fuga a única solução para se libertar de uma caixa fechada, às vezes quase asfixiante. (UDPS, p. 95)

A impressão de vencer o tempo juntamente com o desejo de sair, ir para longe de um cotidiano e das relações com as quais não sabe lidar são causas da atração de Saudade pela escrita. Descobre nas páginas preenchidas com as impressões da vida a sua única fuga possível, então o caderno se tornará um refúgio do cotidiano indesejado no qual ela cresce entre a solidão e as "ordens firmes" da madrasta, havendo também as proibições.

Ela era "uma criança que a solidão fizera crescer, tornara reflectida" (UDPS, p. 95). A solução encontrada pela menina é desviar-se do contato social e confinar sua vida de ausências nas páginas preenchidas diariamente, resguardando-se assim do contato com a sociedade que não a compreendia:

O diário passou a ser o grande amigo de Saudade, o único até, já que não sabia criar amizades entre as colegas. Era um amigo compreensivo, a quem tudo podia ser dito, e que a acompanhava por toda a parte. Falava pois com ele, confiadamente, contava-lhe os seus desgostos em casa, onde se sentia tão só, na escola onde estava mais só ainda. (UDPS, p. 96)

Porém tudo desmorona quando a menina se sente ameaçada pelo confronto com o outro e pela falência de seus segredos, quando vê o diário em posse da menina que era sua ameaça, justo a que representava o outro forte que desafiava a solidão de Saudade. É nesse momento que o narrador descreve uma das cenas mais 
significativas do conto, revelando-nos como em uma pintura toda a passividade da menina paralisada diante de seu infortúnio: "Saudade não conseguia mexer-se era como se de repente deixasse de ter sangue quente e móvel. Uma estátua de gelo no meio da multidão" (UDPS, p. 98).

O caderno logo vai parar nas mãos da professora, então cresce o pavor da menina diante da ameaça de ter suas reflexões reveladas é dar-se a conhecer pelos colegas e pela escola. Subitamente ela é desperta da paralisia, a estátua se derrete e assim como a água, a menina corre desnorteada sem parar, pois após o choque ela não cabia mais no local onde estava, repetindo assim a atitude da mãe. No entanto, vai ainda mais longe e acidentalmente ou não, esbarra com o ônibus que passava na avenida em frente à escola, atira-se para o único rumo possível: a morte.

Depois, no entanto, tudo correu bem. Provou-se que a morte fora casual, que a pequena ia a fugir do colégio (estas coisas herdam-se, infelizmente, e a mãe também fugira um dia, disse o próprio pai, melancólico) (...) no fundo todos gostavam da Saudade, criança retraída e isolada (evitaram a palavra antipática) que não gostava de ninguém. (UDPS, p. 100)

A dificuldade da menina em enfrentar o mundo e as situações que diante dela se colocam a faz tornar-se também uma fugitiva, foge ao convívio social, á realidade de solidão e ausência, ao controle inquietante da madrasta. Seu mundo fora quebrado antes de se construir à semelhança dos malogros que configuram o mundo das mulheres juditianas.

A passividade diante da vida e a dificuldade nas relações com o outro que observamos na história da protagonista juditiana a aproximam da adolescente que protagoniza o conto "Preciosidade", de Clarice Lispector. A descrição feita pelo narrador é sutil, mas nos desenha de antemão a intensidade das reflexões e os medos que se repetiam nas manhãs da protagonista:

Tinha quinze anos e não era bonita. Mas por dentro da magreza, a vastidão quase majestosa em que se movia como dentro de uma meditação. E dentro da nebulosidade algo precioso. Que não se espreguiçava, não se comprometia, não se contaminava. Que era intenso como uma jóia. Ela. (P, p.103) 
As saídas todas as manhãs para a escola constituíam de certa forma ritos ou tentativas de amadurecimento. O desafio de se fazer intocável diante dos homens no ônibus, a possibilidade de ter sobre si o olhar dos outros a assustava, e ia surpreendendo-se consigo mesma com as mudanças que the chegavam "à medida que dezesseis anos se aproximavam em fumaça e calor", assim como sua "sombra de moça sem homem" se tornava o desafio a ultrapassar. Sua curiosidade diante do mundo e das transformações pelas quais passava faziam dela uma menina diferente, possuía uma "cabeça pensante" que incomodava os colegas, sobretudo os rapazes que desejavam sempre ensinar algo a ela.

$\mathrm{O}$ ar reflexivo e arredio da protagonista a deixava em um estado de solidão e deslocamento, fazendo dela uma "transgressora" perante os grupos da escola. Um mundo de pensamentos e devaneios durante as aulas a exilava do espaço da sala, e de seu lugar de mulher. Sua inteligência era uma ameaça para os meninos da escola, por isso era "tratada como um rapaz", com rivalidade e distância: "Cada vez mais a grande fingida se tornava inteligente. Aprendera a pensar. O sacrifício necessário: assim 'ninguém tinha coragem'” ( $P$, p.106).

A relação cautelosa da protagonista diante do outro, o mal estar com os meninos da escola e a falta de jeito com os acontecimentos cotidianos nos remetem à menina Sofia, em "Os desastres de Sofia" essa pequena transgressora também ocupa diante dos outros o papel de perigosa e perversa devido a seu comportamento precoce e suas idéias para além do lugar que deveria ocupar. Ela não acredita mais na existência de tesouros a encontrar e consegue "tirar a moral das histórias" nas redações da escola, assustando o professor e os colegas com sua coragem:

É possível também que já então meu tema de vida fosse a irrazoável esperança, e que eu já tivesse iniciado a minha grande obstinação: eu daria tudo que era meu por nada, mas queria que tudo me fosse dado por nada. Ao contrário do trabalhador da história, na composição eu sacudia dos ombros todos os deveres e dela saía livre e pobre, e com um tesouro na mão. (LISPECTOR, 1992, p. 16)

Porém vemos que a ousadia e o ar transgressor da menina Sofia são bem mais moderados no comportamento da jovem protagonista de "Preciosidade", ela teme o outro, não o enfrenta diretamente, mas sabe fazer dele seu lugar de refúgio e seu 
possível caminho para a maturidade. Transfigura-se, cria refúgios para proteger-se do convívio, vencê-lo, mas não foge dele, o enfrenta, sendo este um aspecto no qual a personagem clariceana se diferencia de Saudade, que como acima vimos, foge totalmente ao encontro com o outro.

As reações da adolescente diante das situações do cotidiano eram diferenciadas como se para cada momento ela ocupasse papéis diversos, ou como se usasse máscaras adequadas a cada "combate": no ônibus logo cedo entrava séria "como uma missionária", para desviar-se do olhar dos homens. Depois atravessava a rua como "um soldado" rumo ao bonde, e se mantinha firme em meio à batalha do trajeto. Então a guerra se prolongava até os corredores da escola os quais ela atravessa "como a um silêncio de trincheira". Na volta escondia-se na "espécie de feiúra que a fome acrescentava", em casa, já protegida da liberdade da rua, comia "como um centauro", então tudo se repetia e na manhã seguinte ela despertava novamente como a "princesa do mistério intacto".

Observamos que, nas várias máscaras usadas pela mocinha, há a tentativa de passar pela situação sem ferir-se, sem que o mundo a toque de maneira a derrubar os muros que ela tenta construir ao seu redor. Não podemos esquecer também que a máscara como metáfora da proteção é muito recorrente na obra clariceana. A necessidade de portar uma máscara para viver é por ela explicada em uma de suas crônicas:

Por que então me agrada tanto a idéia de atores entrarem no palco sem rosto próprio? Quem sabe, eu acho que a máscara é um dar-se tão importante quanto o dar-se pela dor do rosto. Inclusive os adolescentes, estes que são puro rosto, á medida que vão vivendo fabricam a própria máscara. E com muita dor. Porque saber que de então em diante se vai passar a representar um papel é uma surpresa amedrontadora. É a liberdade horrível de não ser. E a hora da escolha. (LISPECTOR, 1994, p. 77)

E a cronista continua confessando que também ela usa sua máscara e que a necessidade de usá-la relaciona-se diretamente "ao parto da adolescência", momento difícil em que tudo que se quer é proteger-se do mundo e do outro, então é preciso escolher uma proteção "para não ficar desnudo para o resto da luta". Clarice nos 
explica o perigo de trazer consigo um rosto nu, ou de vê-lo desnudado diante do outro: "Mas é que esse rosto que estava nu poderia, ao ferir-se, fechar-se sozinho em súbita máscara involuntária e terrível" (LISPECTOR, 1994, p. 77). A autora nos explica que, atrás da máscara que escolhemos para a representação social, é possível ser forte e passar ileso por aquilo que poderia nos ferir:

Mas quando enfim se afivela a máscara daquilo que se escolheu para representar-se e representar o mundo, o corpo ganha uma nova firmeza, a cabeça ergue-se altiva como a de quem superou um obstáculo. A pessoa é. (LISPECTOR, p. 78)

No entanto Lispector finaliza tal crônica alertando para a fragilidade que tem a máscara social, podendo espedaçar-se a qualquer momento e o rosto nu será ferido para sempre, sendo marcado pelo peso forte da realidade. Podemos observar que as representações da protagonista enquadram-se bem na necessidade de mascarar-se diante do mundo. Mas de repente a proteção da adolescente é destruída pelo confronto, no dia em que quebra seu ritual e sai mais cedo "para o imprevisível da rua" vê-se diante de dois homens, não encontra nenhuma máscara com a qual possa enfrentá-los, tem o rosto nu e perde a impessoalidade. Caminha diante dos homens como que se arriscando a ser "um ela-mesma que a tradição não amparava", entregue ao embate com o outro:

Por um instante hesitou toda, perdida de um rumo. Mas era tarde demais para recuar. Só não seria tarde demais se corresse. Mas correr seria como errar todos os passos, e perder o ritmo que ainda a sustentava, o ritmo que era o seu único talismã (...) E mesmo quando se foge correm atrás, são coisas que se sabem. ( $P$, p. 111)

E como não há possibilidade de volta a adolescente recusa-se a desistir e entrega-se para um confronto. A adolescente se sente coagida, tal como Saudade ela também quer fugir, livrar-se daquele choque de ser descoberta pelo outro. Mas diferente da personagem juditiana, ela continua, desiste de correr e enfrenta o embate com o desconhecido. Assim livra-se da punição que sofrera Saudade, morta por ter tido pressa em desafivelar sua máscara. 
Os dois homens, que marcham alheios á importância que tinham naquele instante, são o "mistério" e a superação para a "preciosidade" do rito de passagem da protagonista:

Eles, cujo papel predeterminado era apenas o de passar junto do escuro de seu medo, e então o primeiro dos sete mistérios cairia; eles que representariam apenas o horizonte de um só passo aproximado, eles não compreenderam a função que tinham e, com a individualidade dos que têm medo, haviam atacado. ( $P$, p. 112)

O choque a suspende para a maturidade e deixa a adolescente primeiramente agitada, mas após passar pelos homens todo o seu corpo estagna-se, o mundo se imobiliza a sua volta. O tempo é alargado e redimensionado em uma duração preciosa para a adolescente: "Foi menos de uma fração de segundo na rua tranqüila. Numa fração de segundo a tocaram como se a eles coubessem todos os sete mistérios" ( $P$, p. 112).

A cena descrita pelo narrador clariceano, leva-nos novamente a um paralelo com a narrativa juditiana, salvaguardando as diferenças. Saudade torna-se imóvel no momento em que se vê nas mãos dos colegas, paralisa-se antes de correr para a morte, ponto final de sua fuga. Enquanto a personagem clariceana vive esse estado após o confronto, depois do choque, e em etapas diferentes. A voz narrativa descreve sua imobilidade, como se a adolescente tivesse sido salva por não haver corrido:

Então, como se houvesse várias etapas da mesma imobilidade, ficou parada. Daí a pouco suspirou. E em nova etapa manteve-se parada. Depois mexeu a cabeça, e então ficou mais profundamente parada. Depois mexeu a cabeça, e então ficou mais profundamente parada. $(P$, p. 113)

O encontro é a grande batalha pela qual ela passa, e no momento seguinte, após o período de estagnação já é adulta. A adolescente dera as mãos para a moça, está feito seu rito de passagem, que não fora interrompido como o de Saudade. $O$ mundo ao redor é outro, e as coisas estão mais fora de lugar do que na realidade que ela havia programado seguir, como em ritual que se partiu e espalhou-se a sua volta: 
Depois amanheceu.

Devagar reuniu os livros espalhados pelo chão. Mais adiante estava o caderno aberto. Quando se abaixou para recolhê-lo, viu a letra redonda e graúda que até esta manhã fora sua. $(P, p .114)$

O quadro acima, com os objetos espalhados pelo chão, como se a moça acabasse de sair de uma (re)arrumação de si mesma, lembra-nos uma cena de "O búfalo". Trata-se do momento em que o narrador compara a situação de angústia após descer da montanha russa com o dia em que a mulher viu todos os pertences da bolsa espalharem-se pelo chão, sendo obrigada a recuperar um a um os detalhes de sua intimidade de mulher ferida:

Contrita como no dia em que no meio de todo o mundo tudo o que tinha na bolsa caíra no chão e tudo o que tivera valor enquanto secreto na bolsa, ao ser exposto na poeira da rua, revelara a mesquinharia de uma vida íntima de precauções: pó-de-arroz, recibo, caneta-tinteiro, ela recolhendo do meio-fio os andaimes de sua vida. (OB, p. 161)

Após o confronto vivido os olhos da menina-mulher se abrem, ela vê a si e aos outros mais intensamente, então tem a mesma descoberta que tanto atormentara Saudade, o lugar de solidão que ocupa no mundo, a solidão das mulheres que pela reflexão ou pelo comportamento seguem sempre sós: "Nunca ninguém vai me ajudar, nunca ninguém vai me amar! Estou sozinha no mundo!" ( $P$, p. 114). Esta constatação vem seguida da lucidez de ver-se como realmente é, sem as ilusões da ingenuidade que até então a protegeram, e no banheiro da escola, diante do espelho descobre que "era tão feia" e "possuía tão pouco".

Assim a menina tornou-se mulher, e à mesa do jantar exigiu freneticamente que lhe dessem sapatos novos, e perdeu a "preciosidade" que tanto resguardara atrás de suas máscaras:

Até que, assim como uma pessoa engorda, ela deixou, sem saber por que processo, de ser preciosa. Há uma obscura lei que faz com que se proteja o ovo até que nasça o pinto, pássaro de fogo.

E ela ganhou os sapatos novos. (P, p. 116) 
Ao observarmos o rito de passagem na vida da menina juditiana e da adolescente de Clarice, vemos que a primeira tem sua maturidade antecipada pela partida da mãe. A ruptura com a inconsciência uterina e a mágoa com a presença de uma madrasta a fazem fugir do contato com o outro até à morte. Morre com idade de menina, mas como se já fosse uma adulta frustrada com o passado.

A adolescente "preciosa" vive em cada momento do conto uma etapa de preparação para a maturidade da qual ela tenta fugir mascarando-se. Mas nos dois trajetos vemos problemas parecidos: a falência nas relações sociais, problemas culturais e afetivos nas relações do feminino e do masculino e o grande combate entre destino e liberdade.

A fuga também será um ponto relevante entre as duas protagonistas. A necessidade de buscar um recurso para fora do cotidiano manifesta-se em ambos os enredos pela dificuldade de confrontar-se consigo mesma e com o outro. E esta necessidade é simbolizada pelo desejo de correr, presente nas duas cenas analisadas. Porém serão desejos construídos de maneiras diferentes e que produzem reações opostas. Saudade segue ao impulso, corre levando tudo que estava a sua frente, só pára diante da morte, enquanto a adolescente do conto clariceano reluta contra a vontade de fugir, briga consigo mesma e prossegue, esta atitude a faz sobreviver, ser adulta, porém solitária dentro de sua nova condição.

Para Saudade a saída pela morte anula toda a possibilidade de resistência, já para a protagonista de Lispector, a insistência de viver seu rito de passagem, ser tocada e ferida pelo outro, a faz sair do mundo onde vivia protegida pela condição de menina. Sai do embate com olhos de ver, e o mundo que the é revelado posteriormente é acompanhado de certa melancolia. A trajetória das protagonistas vai gradativamente ganhando importância ao longo do texto, envolvidas em situações aparentemente banais do cotidiano. A menina e a adolescente vão emergindo de tais situações, sendo descritas também pela maneira particular como passam por espaços como a rua ou a escola.

Assim cabe ao leitor ir recriando a imagem das protagonistas à medida que a narrativa nos denuncia os diferentes tons de sensibilidades com os quais são 
envolvidas. A recriação da imagem da personagem, segundo Vincent Jouve ${ }^{132}$, reformula-se mais por aquilo que se esconde do que pelo que é mostrado no texto, jogo muito bem estruturado nos universos de Clarice e de Maria Judite. Nas palavras do autor, as personagens

exigent de la part du lecteur une véritable 'recréation' imaginaire. Le personnage romanesque, autrement dit, ne jamais le produit d'une perception mais d'une représentation. ${ }^{133}$.(JOUVE, 1992, p. 40)

Seguindo o argumento de Vincent Jouve, no decorrer da leitura dos contos criamos imagens distintas para as duas personagens, o que se justifica também nos caminhos percorridos por ambas. A menina e a adolescente se distanciam no eixo oposto da persistência e da desistência, a primeira atribuída a adolescente que vai vencendo os embates com o outro e que no último momento pensa em recuar. Mas não aceita desviar seu destino, passa pela ameaça dos homens na rua vazia e se torna mulher, mesmo que consciente de sua solidão. Saudade não consegue manterse resistente diante da insistência do outro em adentrar seu mundo íntimo e inviolável, interrompe o próprio destino e corre para a morte.

O papel das personagens nas duas narrativas está ligado também ao seu estado afetivo, à maneira que tal estado se desenvolve para uma e para outra. E o leitor parte também do contexto familiar de ambas para seguir a trajetória de fuga e de enfrentamento, seguida pela menina e pela adolescente. Como nos explica Jouve, é sob o plano emocional e intelectual que o sujeito vai se apresentar no plano literário e o leitor tem participação ativa em tal processo de criação:

Le lecteur a ainsi une part active dans la création des pesonnages: il est absent du monde represente, mais présent dans le texte (...) en tant que conscience percevante. II joue, pour les figures romanesques, le rôle de témoin et d'adjuvant ${ }^{134}$. (JOUVE, 1992, p. 39).

\footnotetext{
132 JOUVE, Vincent. L'effet-personnage dans le roman. Paris : Presses Univesitaires de France, 1992.

${ }^{133}$ Exigem da parte do leitor uma verdadeira recriação imaginária. O personagem do romance, como dito antes, não é jamais o produto de uma percepção, mas de uma representação.

${ }^{134}$ Assim o leitor tem uma parte ativa na criação das personagens: ele é ausente do mundo representado mas presente no texto (...) enquanto consciência perceptiva. Ele representa, através das figuras do romance, os papéis de testemunha e coadjuvante.
} 
Saudade representa as imagens de ausência, da mãe, de amigos; e de uma falência, dos laços afetivos com o pai e com os outros a seu redor. A fatalidade na vida da protagonista é antecipada pelo narrador, quando nos denuncia que a menina ainda não tinha, e "nunca, de resto a teria", idade para entender o ódio do pai pela mãe fugitiva. Enquanto que a adolescente, personagem de Clarice, nos surpreende até o último momento de seu confronto na rua deserta. Suas máscaras de proteção parecem de tal forma bem seguras que não imaginamos que a protagonista vai render-se ao embate.

O ritual da saída todas as manhãs, o contato com a liberdade da rua, deixam sutilmente implícito que algo se prepara, e que logo a "preciosidade" da adolescente será incomodada. Como é comum no histórico das personagens femininas do universo de Lispector, a aparente tranqüilidade logo se confronta com choque. A calma ida à escola todas as manhãs, torna-se um falso indício de normalidade, o que contribui para a grandiosidade do texto e para o crescimento da protagonista, e favorece seu diálogo com outras personagens clariceanas. Tal diálogo é necessário, pois, como nos explica o teórico francês:

La figure romanesque est rarement perçue comme une creature originelle, mais rappelle souvent, de manière plus ou moins implicite, d'autres figures issues d'autres textes. Le personnage ne se réduit pas à ce que le roman nous dit de lui. ${ }^{135}$ (JOUVE, 1992, p. 40)

É certo que o enredo juditiano também nos surpreende, não apenas com a reação da menina Saudade que de "estátua de gelo" passa a "água corrente" rumo à morte, mas com muitas das mulheres fugitivas que passaram por esse capítulo, como Camila que quando pensamos que pintará um quadro atira-se pela janela.

Cenas que o narrador constrói com crueza, em frases curtas e marcantes, dando a exata dimensão do malogro vivido pelas personagens, ou ainda de seu estado de solidão irreversível. A evolução das personagens de Maria Judite e Clarice ocorre em um eixo muito aproximado, tanto a adolescente quanto Saudade são personagens

\footnotetext{
${ }^{135}$ A figura romanesca é raramente percebida como uma criatura original, mas lembra geralmente, de maneira mais ou menos implícita, outras figuras vindas de outros textos. O personagem não se reduz ao que o romance nos diz dele.
} 
que crescem mais pelo silêncio do que pelo dito, evoluem dentro de sua capacidade de refletir sobre o aparentemente banal.

O caminho de aproximação entre as personagens nos leva a importantes aspectos no que diz respeito à falência nas relações sociais e no enfrentamento da realidade. Este tem sido tema muito recorrente na escritura de autoria feminina, dita como intimista, como já nos referimos no capítulo inicial. Mas o que nos interessa ressaltar é que a fuga interrompida, a falência na tentativa de um vôo está diretamente relacionada com a incapacidade de se relacionar no meio social, com o peso resultante da condição.

E por conseqüência a condição relaciona-se também com o papel social exercido pela mulher e que foi criado e determinado pelo homem, sendo por isso difícil de exercer, seja na escola, na rua ou na vida em geral. Tal dificuldade é intensificada pelo medo de seguir um destino criado pelo outro, existindo sempre como uma sombra na vida dessas personagens femininas, independente da idade ou da classe social. Portanto serão sempre fugitivas, caso não queiram viver sob a conduta social que para elas foi criada.

La condiction concrète de la femme n'est pas affectée par le type de filiation qui prévaut dans la société à laquelle elle appartient ; que le régime soit patrilinear, matrilinear, bilatéral ou indifférencié (...) elle est toujours sous la tutelle des hommes ${ }^{136}$ (BEAUVOIR, 1949, vol. I, p. 125)

Este questionamento da personagem em relação ao lugar que ocupa na sociedade é freqüente no universo das duas escritoras. É principalmente nesse ponto que essas personagens ganham mais importância, pois são peças fundamentais para denunciar o mal-estar que a mulher enfrenta para "cumprir" a condição a ela imposta, anulando sua existência como sujeito. Chegamos então ao ponto interessante que é a observação de retratos de uma sociedade e suas particularidades. A sociedade carioca de classe média, no espaço de Clarice, e o comportamento exigido da mulher lisboeta da época, no espaço de Maria Judite.

\footnotetext{
${ }^{136}$ A condição concreta da mulher não é afetada pelo tipo de filiação que prevalece na sociedade a que ela pertence; seja o regime patrilinear, matrilinear, bilateral ou indiferenciado (...), ela se encontra sempre sob a tutela dos homens.
} 
Antonio Candido ${ }^{137}$ nos explica que é quase impossível pensar na personagem sem recorrer ao enredo, uma vez que aquela se torna peça fundamental atrelada a este. É através das personagens em diferentes situações cotidianas que podemos identificar nas narrativas aqui referidas alguns retratos de um mesmo momento histórico-social com suas regras de práticas e costumes:

quando pensamos no enredo, pensamos simultaneamente nas personagens; quando pensamos nestas, pensamos simultaneamente na vida que vivem, nos problemas em que se enredam, na linha do seu destino - traçada conforme uma certa duração temporal, referida a determinadas condições de ambiente. (CANDIDO, 2000, p. 53)

Seguindo o ponto de vista de Candido, aquilo que apreendemos da personagem nos parece um tanto fragmentário mesmo que o autor nos dê uma visão geral da mesma, esta impressão contribui para nos surpreendermos em relação à determinada atitude que tomem. No entanto esta surpresa é o que contribui para a grandiosidade estrutural da personagem e para o "encanto da ficção".

Percebemos essa mudança de direção de maneira freqüente nas personagens analisadas neste capítulo, seja pela surpresa de vermos Adelaide retornar com sua mala, como formiga perdida na multidão, ou Elvira, a fugitiva, que durante horas de andanças nos faz crer que partirá. Mas deixa seu navio partir sem ela noite a dentro, e as tantas outras com suas reações surpreendentes diante da inquietude da própria condição.

São personagens que ganham força, possuem uma estrutura bem organizada, seguem numa trajetória que as aproxima uma das outras, mas sempre guardando suas particularidades e maneiras diferentes de nos revelar os malogros do feminino. Pela complexidade que atingem e pela linha de criação das autoras, podemos dizer que são "Personagens criadas em torno de um modo geral dominante, que serve de eixo, ao qual vêm juntar-se outros modelos secundários, tudo refeito e construído pela imaginação". (CANDIDO, 2000, p. 72).

Finalmente no eixo que liga todas as personagens acima referidas, vemos um dado importante: o conflito entre condição e liberdade e a impossibilidade de fugir do

\footnotetext{
${ }^{137}$ CANDIDO, Antonio. “A personagem do romance”, em A personagem de ficção. São Paulo, Perspectiva, 2000.
} 
próprio destino. As fugas planejadas ou não são apenas projeções de uma existência por vezes oprimida e que se quer outra. As tentativas de escapar são seguidas de falências refletidas seja no retorno da personagem, conseqüência da impossibilidade de continuar sem a proteção dos dias "tranqüilos"; seja porque têm como conseqüência a consumação da própria vida. Mas a trajetória dessas mulheres faz com que o rompimento torne-se uma ilusão, um ensaio que depois as conduz ou ao mesmo lugar ou a um sem-rumo.

Essa impossibilidade dialoga com os muros do cotidiano nos quais estão inseridas as mulheres. A dificuldade das relações ou o sentimento de exílio, que habita no interior das personagens independe de sua idade ou ritmo de vida. Existe sempre em volta delas uma solidão e um sofrimento quase sempre impossíveis de se resolver e que fazem das personagens seres isolados, exilados à margem de um papel social.

O estado de fugitivas é de fato mais uma etapa da transgressão assistida pela qual passam, e com a qual muitas vezes compactuam, ou simplesmente aceitam sem relutar, como defende Rocha-Coutinho:

Nem vítimas, nem algozes, acreditamos que as mulheres ao longo dos anos foram tecendo modos de resistência a essa opressão masculina, formas de exercer um certo controle sobre suas vidas a despeito de uma situação social tão adversa. (ROCHA-COUTINHO, 1994, p. 19)

\subsection{Desatando os laços: encontros e desencontros}

Ainda sob a temática da fuga, aproximamos dois contos que se voltam para a família patriarcal e a crise das mulheres no seio de tais famílias. "Os laços de família" que, semelhante ao título do volume de contos de Clarice, é também o tema que de várias maneiras percorre as treze narrativas do livro; e "Carta aberta à família", de Flores ao telefone, sobre a delicada relação entre mãe e filho.

Em "Os laços de família" acompanhamos um dia de sábado no cotidiano de uma família de classe média alta, vivendo no Rio de Janeiro. A cena inicial é 
aparentemente comum: a filha acompanha a mãe até a estação de trem, no entanto há uma preocupação que persiste na matriarca: ter esquecido algo na casa da filha. A velha mulher se ocupa de contar as malas e de perguntar insistentemente à filha se nada havia ficado para trás.

As relações familiares são o tema principal desta narrativa que põe à prova o afeto entre mãe e filha, mulher e marido e mãe e filho. A filha, Catarina, com "seus olhos escuros, a que um ligeiro estrabismo dava um contínuo brilho de zombaria e frieza", assistia irônica à falta de jeito também na relação entre sogra e genro:

Ainda estava sob a impressão da cena meio cômica entre sua mãe e seu marido, na hora da despedida. Durante as duas semanas da visita da velha, os dois mal se haviam suportado; os bons-dias e as boas-tardes soavam a cada momento com uma delicadeza cautelosa que a fazia querer rir. (OLF, p. 117).

Acostumadas a substituir o afeto pelas banalidades do cotidiano, as duas mulheres vivem em um grau de frieza que não permite o perigo da proximidade. Porém no caminho para a estação se dá uma certa mudança na relação entre mãe e filha. À distância a que se habituaram é quebrada por um momento aparentemente banal, sem nenhuma importância, mas que, como de costume nos enredos clariceanos, desencadeará o conflito. De repente uma freada brusca no táxi que as conduzia à estação as lança uma contra a outra, obrigando-as ao abraço e ao constrangimento de se saberem de repente próximas. O choque revela-se em ambas como um "desastre" irremediável:

Catarina olhava a mãe, e a mãe olhava a filha, e também a Catarina acontecera um desastre? Seus olhos piscaram surpreendidos, ela ajeitava depressa as malas, a bolsa, procurando o mais rápido possível remediar a catástrofe. Porque de fato sucedera alguma coisa, seria inútil esconder: Catarina fora lançada contra Severina, numa intimidade de corpo há muito esquecida, vinda do tempo em que se tem pai e mãe. (OLF, p. 119)

Tal cena nos reporta ao momento em que Ana, como visto algumas páginas acima, deixa quebrarem-se os ovos e também seu equilíbrio. $O$ efeito será de quebra para Severina e Catarina, o acontecimento as deixa totalmente desencontradas, e o 
narrador em terceira pessoa também sai do instante da cena e vai para o passado para explicar que nunca houvera intimidade entre mãe e filha. $O$ vazio do silêncio é preenchido com a repetição da mãe sobre ter esquecido algo na casa da filha, observamos então que são os laços afetivos que há muito foram esquecidos entre elas: "Também a Catarina parecia que haviam esquecido alguma coisa, e ambas se olhavam atônitas - porque se realmente haviam esquecido agora era tarde demais" (OLF: 121).

Muitas coisas haviam sido esquecidas entre as duas, o afeto, o jeito para se reconhecerem como mãe e filha. Havia uma imensa dificuldade em vencerem o afastamento criado por banalidades e regras sociais, no entanto a partida da mãe deixa Catarina diferente, o choque sofrido no táxi a acompanha e o rompimento com o mundo de antes se dá através da nova imagem assumida por ela e pela paisagem ao redor, "a força fluía e refluía em seu coração com pesada riqueza".

$\mathrm{Na}$ volta pra casa, olhos estrábicos de Catarina captam os mínimos detalhes em ampliação e ela sente-se pelas ruas em extremo à vontade como se em um lugar íntimo. Em seguida vemos que de fato ela havia trocado de lugar, estava fora do que tinha sido sua calma natureza até então:

Estava muito bonita neste momento, tão elegante; integrada na sua época e na cidade onde nascera como se a tivesse escolhido. Nos olhos vesgos qualquer pessoa adivinharia o gosto que essa mulher tinha pelas coisas do mundo. Espiava as pessoas com insistência, procurando fixar naquelas figuras mutáveis seu prazer ainda úmido de lágrimas pela mãe. (OLF, p. 122)

O estrabismo de Catarina é citado várias vezes pelo narrador, e se torna um dado importante, já que a maior fonte de expressão da protagonista são os olhos. Seu olhar estrábico pode ter um duplo significado: antes de ser lançada contra a mãe no táxi podemos entendê-lo como uma miopia, mas que depois se torna uma amplitude de visão, que a faz ver-se de outra maneira. A caminhada de volta pra casa é também reveladora, o novo contato com o mundo a faz sentir que havia subido "mais um degrau misterioso nos seus dias". (OLF, p. 123).

Quando a mulher reencontra a família há um dado novo, pois diferente de outros contos da autora como "Amor" ou "A fuga", em que voltar pra casa representa a 
pacificação, para Catarina será o momento para romper com os laços de calma submissão que a ligavam ao marido. A determinação com a qual rompe porta a dentro assusta e diminui a autoridade do marido, provando que ela realmente estava "disposta a usufruir da largueza do mundo inteiro, caminho aberto pela sua mãe que the ardia no peito". (OLF; 123). Em seguida ela se lançará de maneira diferente para o filho, assim como fora, acidentalmente, lançada contra Severina.

A relação de Catarina com o filho também parece conturbada pelos momentos passados na estação, ao entrar no quarto ela encontra o menino com os olhos "indiferentes para o ar, comunicando-se consigo mesmo" (OLF, p. 123). Ele se mantém fechado em seu mundo particular de menino "nervoso", onde não há lugar para ela. No entanto, a mulher tenta combater a distância, que há pouco foi quebrada pelo abraço forçado com a mãe. Mas o filho permanece ensimesmado, com os olhos perdidos e distantes.

O choque que houve entre mãe e filha no táxi repete-se para Catarina ao ouvir do filho a mesma palavra que tão dificilmente pronunciara e que a declarava como sua mãe. Ele que até então se comunicava "apenas consigo mesmo", de repente compartilhava da "catástrofe" da mãe. Como em uma circularidade, a mãe desperta para o filho com a mesma palavra que há pouco pronunciara na estação de trem: mamãe. E na intenção de salvar o filho do que acabara de viver com Severina, a protagonista quebra o invólucro de frieza do qual acabara de fugir. Ela pega o menino pelo braço e sai deixando o marido ofendido dentro de sua autoridade:

- Vamos passear; respondeu corando e pegando-o pela mão.

Passou pela sala, sem parar avisou o marido: vamos sair! $E$ bateu a porta do apartamento.

Antonio mal teve tempo de levantar os olhos do livro - e com surpresa espiava a sala já vazia. (OLF, p. 124)

Ao sair com o menino, Catarina quebra a hegemonia do marido e perturba a rotina de seu sábado, dia que ele tomava inteiro para si. Observamos que o quadro descrito pelo narrador é o de uma família patriarcal, com os papéis estabelecidos, dando ao homem a autoridade sobre os demais: "Porque sábado era seu, mas ele 
queria que sua mulher e seu filho estivessem em casa enquanto ele tomava o seu sábado" (OLF, p. 124).

A partida de mãe e filho unidos em silêncio e sem rumo os colocará para fora do domínio do homem. Os dois tornam-se imagens estranhas que vistas de cima perdem a perspectiva familiar aos olhos do marido. O narrador que até então se ocupara de expor os sentimentos da protagonista e acompanhá-la em sua fuga, voltase para dentro da casa com o intuito de descrever como se construía de fato a aparente normalidade da vida de Catarina. É através dos olhos do marido pela janela que começamos a partilhar os conflitos que levaram a mulher a se evadir:

Por que andava ela tão forte, segurando a mão da criança? Pela janela via sua mulher prendendo com força a mão da criança e caminhando depressa, com os olhos fixos adiante; e, mesmo sem ver, o homem adivinhava sua boca endurecida. (OLF, p. 125)

O momento da suposta "fuga" é também aquele aproveitado pelo narrador para desenhar o quadro de um casamento ocorrido exatamente nos moldes da família patriarcal. Os papeis são executados sem contestação: o marido tem sua carreira de engenheiro bem sucedido, oferece à mulher seu "sucesso", e essa se ocupa dele, do menino e de manter a família em ordem. Mas a vida planejada sufoca Catarina, que resolve fugir da organização do cotidiano, ela surpreende o marido por deixá-lo só dentro das paredes bem alinhadas do apartamento, incomodando o sábado que ele decretara como "seu dia":

Quem sabe se sua mulher estava fugindo com o filho da sala de luz bem regulada, dos móveis bem escolhidos, das cortinas e dos quadros? Fora isso o que ele lhe dera. Apartamento de um engenheiro. (OLF, p. 126) 
O papel submisso da mulher é facilmente reconhecido na descrição do narrador sobre a relação dos dois, ressaltando que é o marido o responsável pelas decisões da casa. Catarina é a segunda pessoa, sendo muitas vezes diminuída pelas vontades de Antônio:

Por que precisava humilhá-la? No entanto ele bem sabia que ela só seria de um homem enquanto fosse orgulhosa. Mas tinha se habituado a torná-la feminina deste modo: humilhava-a com ternura, e já agora ela sorria - sem rancor? Talvez de tudo isso tivessem nascido suas relações pacíficas, e aquelas conversas em voz tranqüila que faziam a atmosfera do lar para a criança. (OLF, p. 126)

O trecho acima descreve em detalhes como se construíra a "tranqüilidade" da vida de mulher casada que Catarina se habituara a levar com Antônio. Nas palavras do narrador vemos uma paz feita pela diminuição da mulher e um casamento mantido na anulação social da protagonista. Ela deveria contentar-se com o sucesso que o marido tinha a the oferecer, e ele, por sua vez, habituara-se a construir tal sucesso sobre a humilhação dela:

Mas ele a olhara da janela, vira-a andar depressa de mãos dadas com o filho, e dissera-se: ela está tomando o momento de alegria - sozinha. Sentira-se frustrado porque há muito não poderia viver senão com ela. $\mathrm{E}$ ela conseguia tomar seus momentos sozinha. (OLF, p. 127)

As relações de Catarina com o mundo e as pessoas ao seu redor são motivo constante de sua falência interior, e a vida de casada levada por ela está muito próxima daquela denunciada por Beauvoir: uma existência relativa na qual cabia à mulher apenas o contentamento com o crescimento do marido e dos filhos, e o equilíbrio da vida conjugal. Ainda que isso lhe custasse uma anulação de seus desejos:

La femme essaie de constituer um univers de permanence et de continuité: mari et enfantas veulent dépasser la situation qu'elle crée et qui n'est pas pour eux q'un donné. C'est pourquoi, si elle répugne à admettre la precarité des activités auxquelles toute sa vie se dévoue, elle est amenée à imposer par la force ses services: de mère et de ménagère elle se fait marâtre et mégère ${ }^{138}$. (BEAUVOIR, vol. II, p. 276)

\footnotetext{
${ }^{138}$ A mulher tenta constituir um universo de permanência e continuidade: marido e filhos querem ultrapassar a situação que ela cria e que não passa para eles de um dado. Eis porque muito lhe repugna admitir a precariedade
} 
O trabalho construído pelo narrador equisciente ${ }^{139}$ mostra as ruínas das relações familiares seguindo uma ordem que de fato acompanha a protagonistas em vários estágios de sua vida. Catarina e a mãe têm forte dificuldade em estabelecer laços de afeto, a falta de jeito da filha para tratar com a mãe causa as várias situações de incômodo na despedida da estação. A origem dos problemas de afeto é apresentada pela voz narradora através de analepses, o distanciamento da mãe vinha do passado e se contrapunha à cumplicidade com o pai: "Do pai, sim, Catarina sempre fora mais amiga. Quando a mãe enchia-Ihes os pratos obrigando-os a comer demais , os dois se olhavam piscando em cumplicidade e a mãe nem notava". (OLF, p. 119).

Em seguida temos uma outra relação delicada enfrentada pela protagonista com o filho. Catarina não sabia exatamente como the dar com o menino "magro e nervoso". Suas tentativas de aproximar-se do filho eram tão repentinas e mal construídas quanto àquela vivida no táxi com Severina. Os recursos utilizados com o menino resultavam em um distanciamento ainda maior:

Lá estava ele mexendo na toalha molhada, exato e distante. A mulher sentia um calor bom e gostaria de prender o menino para sempre a este momento; puxou-lhe a toalha das mãos em censura: este menino! Mas o menino olhava indiferente para o ar, comunicando-se consigo mesmo. (OLF, p. 123)

É na tentativa de reatar o afeto com o filho que se evidencia a falência da relação conjugal que, aparentemente bem construída, estava à beira do choque, ameaçada pela tentativa de rompimento latente nos olhos estrábicos de Catarina. A renúncia de liberdade e a aceitação do destino era o que mantinha a estrutura familiar, e a calma rotineira à qual a mulher se "habituara". No entanto ao pegar o filho pela mão e sair de porta à fora, a mulher tenta transgredir, mas tudo que consegue é uma transgressão assistida. O marido a observa pela janela, vigiando-lhe os paços de mulher "perdida":

das atividades às quais devota toda a sua vida, ela é levada a impor seus serviços pela força: de mãe e dona de casa ela faz-se madrasta e megera.

${ }^{139}$ No presente conto temos um narrador equisciente em terceira pessoa, aquele que, segundo Oscar Tacca, está muito próximo da personagem, relatando sua consciência. 
Levantou-se, foi à janela e um segundo depois enxergou sua mulher e seu filho na calçada.

Os dois haviam parado, a mulher talvez decidindo o caminho a tomar. $\mathrm{E}$ de súbito pondo-se em marcha. (OLF, p. 125).

A situação retratada no trecho acima mostra o estado de desencontro em que se encontra Catarina, sua saída repentina pode ser vista como um ato transgressor. É também uma cena que nos remete à protagonista juditiana, Adelaide, que, em sua suposta fuga é também observada pela janela pelo homem que a fizera sonhar com ilhas distantes:

A porta batera e ele tinha ido à janela e encostara-se à vidraça para a ver sair. Avistara-a a atravessar a rua, devagar, sem olhar para os automóveis; vira-a pousar a mala como que para tomar fôlego e depois começar a descer pelo passeio fora, perdendo-se na multidão. (A, p. 88)

Em "Os laços de família" o enredo apresenta também várias fases de um feminino circular: a menina, buscando segurança no amor do pai; a mulher casada e submetida à autoridade do homem e às obrigações da casa; e por fim a mulher velha com "ar excessivamente severo", compondo uma imagem dolorosa para a filha. A imagem de severidade no rosto velho da mãe move Catarina, por isso ao voltar pra casa, ela toma o filho pela mão, na tentativa de reverter a herança da falida relação de afeto que ela passara a ver:

Quem saberia jamais em que momento a mãe transferia ao filho a herança. E com que sombrio prazer. Agora mãe e filho compreendendose dentro do mistério partilhado. Depois ninguém saberia de que negras raízes se alimenta a liberdade de um homem. (OLF, p. 125)

Catarina e o filho comungam da mesma fuga e o tempo parece estender-se em um presente sob a ameaça de sua ruptura. $O$ instante de liberdade foi ganho pela mãe, que conseguiu estabelecer a mais forte proximidade com o menino, mesmo na incerteza de quem viria a ser o pequeno homem que ela conduzia pela mão. Os dois seguem olhando na mesma direção e são cúmplices silenciosos buscando seu lugar no mundo. 
O marido, excluído do "momento de alegria", planeja junto à janela uma estratégia para a volta da mulher, talvez levá-la ao cinema. Tudo para que se salvassem daquele perigoso dia, o sábado, que ele há muito havia declarado seu dia, foi violado pelo ato transgressor de "sua mulher e seu filho". A voz narrativa se desloca para a consciência de Antonio na tentativa de apaziguar a noite, e assim garantir a repetição do cotidiano.

O marido concentra-se se nas situações rotineiras vividas à mesa e que garantiam horas "pacíficas". No entanto havia um perigo maior que se espalhava pela casa: onde teriam fim os paços firmes de Catarina com seu filho? E será que voltariam? Ou continuariam sua marcha sob o peso da "última luz da tarde"? Ficamos sem saber onde daria o arroubo que a fizera partir levando o menino.

- "Depois do jantar iremos ao cinema", resolveu o homem. Porque depois do cinema seria enfim noite, e este dia se quebraria com as ondas nos rochedos do Arpoador. (OLF, p. 127)

Há no enredo um dado novo, se tivermos por base grande parte das narrativas clariceanas. As personagens da autora voltam geralmente de suas fugas, não mais como partiram, porém tentando salvar-se nas coisas que se repetem. Catarina nos deixa na incerteza se procederá de tal maneira, e também o narrador não deixa pistas do que virá depois da fuga. É no viés da incerteza que o conto termina sem ter de fato um fim.

É o encontro de mãe e filho, no último domingo do mês de outubro que nos introduz em "Carta aberta à família", de Maria Judite, narrativa que tem como protagonista uma mulher "fugitiva". A protagonista resolvera abandonar o marido, que vinha de uma família tradicional, e o filho para viver uma suposta paixão, que ela agora admitia não ter sido tão forte assim. Para compensar sua ausência, passava sempre um domingo com o filho em cada mês, o que aumentava ainda mais a falência dos laços entre os dois. 
O conto se inicia com trecho da suposta carta o confissão que a protagonista pretende deixar ao marido, ou ao filho ou à família, os trechos são identificados por itálico, o que os diferencia daquilo que é contado pela voz narradora:

Foi no último domingo de outubro - encontrávamo-nos sempre no último domingo do mês, de todos os meses (...) foi nesse domingo de céu cinzento e chuva miúda mas constante, que a ideia, que ainda o não era, me aflorou mais uma vez com a brevidade quase inexistente de um vislumbre. (CAF, p. 121)

O início é também o anúncio de um mistério e a denúncia da fria relação entre a mãe e o filho, em circunstâncias que culminarão na falência dos laços familiares. Durante o dia que passam juntos, a protagonista não se reconhece na aparência refinada do menino, criado na tradicional família do marido, em momentos se parecem dois estranhos. O distanciamento se dá pela diferença de classes, ela havia casado com um homem bem mais rico, e após ter "renunciado" ao casamento, voltara a sua condição. Sem nunca ter conseguido ser de fato uma Cercal, família que constava nos livros de História que ela havia lido na escola.

A matéria do conto não traz aparentemente nenhuma novidade no tocante às narrativas juditianas. A temática de um casamento desfeito, que fora concebido sem amor, o engano de uma paixão extra-conjugal que acaba em desilusão. No entanto a maneira como se arquiteta a história e o jogo narrativo através do qual o narrador nos coloca no centro da intimidade da protagonista, é o que podemos chamar de nó.

Grande parte do enredo, como já dito acima, é contada através da carta "aberta" da protagonista dirigida à família Cercal, ou basicamente ao ex-marido e ao filho, ou a ninguém. Há um revezamento entre o narrador que fala da consciência da protagonista, e a própria que se revela em primeira pessoa, temos então uma alternância de voz narradora. É o início da carta que nos introduz no enredo:

Pensamos haver em tal narrativa o que Oscar Tacca chama de jogo de espelhos, pois o narrador após dar a palavra a personagem, entra com a cena do encontro entre mãe e filho:

Ele estava sentado na sua frente, cortando o bife que tinha em cima uma rodela de limão. "É um bocado duro, não é, mãe?" Dissera há dez 
segundos ou há dez minutos - e a mãe tinha acenado que sim, que era, enquanto Ihe olhava com a admiração de sempre para o risco muito certo do cabelo alourado e para as unhas cor-de-rosa e imaculadas (...) Tinha só doze anos mas era Cercal (CAF; 121)

Ao antepor a voz do narrador ao texto confessional da carta, a autora cria uma variedade de pontos de vista ${ }^{140}$ que pode reforçar a idéia que a protagonista começa a desenvolver na "tarde cinza de outubro", a possível solução que começa a lhe surgir como uma turva imagem. A intenção dos discursos entrecruzados do narrador e da personagem é construir, ou acompanhar a construção de, tal imagem cada vez mais forte, justificando-a no passado a partir das circunstâncias vividas pela protagonista.

Eugênio perscruta a situação da mãe, lançando sobre ela seus olhos fixos e seu jeito alinhado, com a imponência comum aos que eram Cercal. Suas perguntas soam provocativas, deixando-a sem jeito e com receio de confessar sua "simplicidade de vida", portanto o melhor era deixar o menino com a ilusão de que ela vive bem. Alguns diálogos mais parecem confrontos:

"A mãe sabe montar a cavalo?" E acrescentara: "A tia Lena sabe. Parece que até ganhou taças, quando era nova. Um dia destes prometeu que mas mostrava".

Dissera-Ihe que era natural que a tia Lena tivesse ganho taças, mas que ela... "Tivemos uma infância e uma adolescência muito diferentes, sabes? A tua tia e o teu pai..." (CAF, p. 122)

Após cada momento do diálogo tenso e frio entre mãe e filho, a voz que narra passa a palavra à protagonista, a narrativa epistolar é retomada, e nela a personagem descreve seus malogros, já reforçados pelo narrador. No entanto ela também se justifica como se estivesse em um tribunal ${ }^{141}$ :

Com o Eugênio eu nunca sabia até onde podia ir, como podia ir, conhecia-o tão pouco e tão mal. Uma vez por mês durante sete anos dá 84 vezes. Tirando as doenças do Eugênio e os meses de Verão que ela passa no Algarve...Era meu filho aquele rapazinho, mas nos nossos breves encontros eu nunca descobrira nele nada de meu. (CAF, p. 123)

\footnotetext{
140 "A variedade de pontos de vista complica-se ainda se tivermos em conta que o narrador pode contar com intenção documental ou fabuladora, em forma de exposição, carta ou memória: epistolário, testamento, diário íntimo ou história maravilhosa, tudo permanece envolto sob a capa que leva o mesmo rótulo de romance." (TACCA; 1983: 25).

${ }^{141}$ Pensamos aqui o tribunal no sentido abordado por Anatol Rosenfeld
} 
Os trechos da carta são expostos paralelamente à narrativa, contribuindo assim para reforçar o nível de verdade ou credibilidade do fato narrado. Tanto a voz do narrador quanto a da protagonista relatam o infortúnio da mulher no centro de um casamento desigual. É a própria mãe que a faz render-se ao dever de se casar com um homem que lhe pudesse assegurar o futuro. Para tais revelações, o narrador dá a palavra, ou a escrita, à protagonista:

Casei-me mas não gostava do meu marido, nem dele nem de ninguém, valha a verdade. A minha mãe dizia: "Olha que não te aparece outro casamento assim. Lembra-te de que o teu pai está velho e doente e de que é a altura de fazeres qualquer coisa por nós. A verdade é que tu não me interessavas, Ricardo, nunca me interessaste. (CAF, p. 126)

A protagonista confessa as circunstâncias de seu casamento, reforça a idéia passada pela voz narrativa de falência das relações conjugais e familiares. Pensamos que em tal caso, a carta significa também um recurso de alteridade e de afirmação do sujeito e no que diz respeito às sensações narradas, a inserção de vários pontos de vista vai contribuir para a riqueza da narrativa.

Mas no momento em que tentamos equilibrar o recurso epistolar com a voz narrativa, nos surpreendemos com uma outra imagem. Somos postos no centro do filme que a mãe assiste com Eugênio, e que não por acaso tem um enredo muito próximo da situação vivida por ela, neste momento não sabemos de onde ecoa a voz narrativa, e durante um longo parágrafo se alternam o narrador que nos expõe o eu da personagem, a confissão da protagonista e o enredo do filme:

Mary era loira tinha grandes olhos azuis e estava apaixonada. O pai contrariava-Ihe, porém, a inclinação, porque tinha em vistas o proprietário de um rancho. A rapariga lutou, e, como não poderia deixar de ser, venceu. Eu não lutei porque não tinha porque lutar, não valia a pena. Só mais tarde é que o problema surgiu, estava casada havia cinco anos. Foi quando me apaixonei. Tive então um gesto pouco hábil que poria contra mim pai, mãe e amigos, não falando, claro está do Ricardo: fui ter com ele e contei-Ihe tudo. Depois sai de casa. Mary corria a cavalo pelos campos. la prevenir Jack de que o fazendeiro arrumara dois assassinos profissionais para o liquidarem nesse mesmo dia, ao pôr do Sol. (CAF, p. 126) 
Cenas do filme se interpõem à carta aberta da protagonista, lembrando novamente o jogo de espelhos que citamos acima. No cinema, os nomes e estereótipos de beleza e bravura nos fazem crer em um romance nos moldes tradicionais: mulher preenche os requisitos de beleza feminina, o homem está dentro dos critérios de coragem. Intercalando-se com o mundo bem construído de Mary está a vida em ruínas da protagonista juditiana.

A personagem do conto não terá a mesma sorte de Mary, pois sua porta de saída, se existe, se construirá por outros rumos. Por isso o que se segue é o relato da falência da vida da personagem, seus deslizes são expostos sem arrependimentos e com melancolia. Ela não os justifica, foram apenas frutos de tempos e ações desencontradas:

Houve um erro de datas. Se eu o tivesse encontrado uns anos antes...Mas nessa altura, vejo-o agora, eu não era Cercal, longe disso, não ia a um bom cabeleireiro, não vestia modelos, não tinha casacos de vison nem jóias de família. Ele teria reparado em mim, dantes? Duvido. De resto ele também não me teria agradado, era cedo. Agora, também não, é tarde. (CAF, p. 127)

Se não havia algum vestígio de amor em seu casamento, ela também não parecia nutri-lo pelo amante, que a fez renunciar ao marido Cercal. E a relação com o filho também não era de todo afetuosa. Ao saírem do cinema, o menino mostra-se contente com o desenrolar do filme e questiona a mãe a respeito da freqüência com que assiste a filmes. Ela disfarça com desculpas vagas e evita confessar para o filho que seus maiores impedimentos são a falta de dinheiro e de companhia. Solidão e dificuldades financeiras juntam-se a um tom de angústia que se acentua conforme a mulher dá andamento a sua confissão:

Não aparecia ninguém ao domingo, era o dia em que o tempo era maior, estático às vezes, quase morto. Eu arrumava gavetas arrumadas, olhava uma vez mais para velhas fotografias, rasgava cartas ou li-as pela centésima vez e só para me certificar de que elas tinham sido autênticas - um dia. Falo no passado, porque enfim...Bem, falo no passado. (CAF, p. 129) 
A personagem escondia do filho o estado de solidão em que vivia, o verdadeiro rumo de sua vida após os Cercal também era um segredo que guardava do filho e de todos. Ela então decide relatar as próprias angústias em sua carta, que talvez não será lida apenas pelo filho, mas que se faz como "uma carta aberta" à família do marido.

Se não havia lugar para ela no casamento, a emancipação também não Ihe parece confortável. Os dias do presente não Ihe trazem alguma esperança, e o que resta é tentar levar até o final a imagem que começara a construir no início de sua confissão, e que se acentua à medida que caminha para o fim do domingo com o filho. Há uma quase aproximação entre eles, e vem a sua cabeça interrogar o menino sobre o assunto "proibido" de sua fuga, portanto tudo fica apenas em um pequeno ensaio:

Agora subiam a avenida e ela gostaria uma vez mais de saber o que pensava o filho do facto de ela ter um dia abandonado tudo, de o ter abandonado mesmo a ele. Que lhe teriam dito? E de que maneira? Gostaria de se defender, de lhe apresentar, de lhe apresentar as circunstâncias atenuantes do seu ato, mas sentia que tudo que dissesse seria improfícuo. Valeria então a pena fazê-lo? (CAF, p. 128)

Perde-se então o único possível momento de afeto entre os dois, a mulher busca no mais íntimo de sua coragem, prepara-se e, como um pássaro que, de repente, escapara da gaiola, questiona-o: "Sentes a minha falta?" (CAF, p. 128). Eugênio, já demonstra cansaço e impaciência pela longa jornada, e responde-lhe com educação, mas friamente, afastando a mínima possibilidade de um prolongamento do assunto: "Oh, com certeza. A tia Lena é muito minha amiga, mas sinto a sua falta" (CAF, p. 129).

Quebram-se as possibilidades de que a mãe possa explicar ao filho os motivos de seu "deslize". A protagonista perdera tudo, não havia como recuperar os anos ou os atos. E ao final do dia cinza de domingo, sentia escapar-lhe também o menino que, diferente dela, tornara-se totalmente Cercal. A certeza de seus malogros aproxima-a ainda mais da imagem de morte como uma possível "solução", o que vinha the acompanhando durante todo aquele domingo: 
Foi então que a imagem voltou. Imagem? Só soube que voltou porque compreendi que estava muito, muito cansada e que não valia a pena insistir mais. Havia uma porta, uma única, e essa estava ali não sei há quanto tempo, embora só nessa altura eu a tivesse visto, e de relance. Uma porta aberta. Compreendi de repente muitas coisas, meu pai, minha mãe, todos os Cercal que lerem esta carta, incluindo o meu filho quando for homem.(CAF, p. 129)

Cansaço e desistência traduzem o desejo de morte da protagonista. E sua "carta aberta" será a justificativa ou apenas o comunicado de que nada mais valia a pena. Não havia laços que a prendessem à vida, nem mesmo os de afeto pelo filho sustentavam a angústia de se saber sem lugar. E suas últimas palavras com Eugênio são já o indício do que havia decidido durante os dolorosos momentos com o filho:

"A vida é uma coisa tão incerta...É tão fácil haver uma fuga de gás, enganarmo-nos num medicamento, ficarmos atropelados...No fundo não há nada tão fácil na vida como morrer. Nós é que nunca pensamos nisso, é o que vale" (CAF, p. 130)

A situação vivida pela protagonista retrata a condição feminina exposta nas obras juditianas: a mulher que não cabe na vida de casada, mas também não consegue emancipar-se. A solidão e o estado de exílio serão sempre mais fortes do que o desejo de liberdade e a conseqüência será um eu dividido face à impossibilidade da vida.

Os dois enredos acima relatados evidenciam conflitos parecidos, em torno da crise do feminino no seio da família patriarcal. As duas protagonistas, a clariceana e a de Maria Judite, não conseguem suportar o peso da condição de mulher casada. Nem mesmo os laços de afeto são capazes de se estabelecer em meio aos conflitos interiores da personagem. Daí então as situações de constrangimentos entre mães e filhos, maridos e esposas, e as costumeiras falências das relações, que são disfarçadas por banalidades do cotidiano.

O casamento é uma das peças motivadoras da angústia das duas mulheres, Catarina e a personagem juditiana são vítimas de uma situação conjugal de desigualdades, que começa pelo campo econômico e estende-se para o social e o 
moral. Os maridos possuem nome, carreira e total autonomia de sujeito, enquanto as mulheres são dependentes e vivem à mercê do crescimento do outro.

Tanto a mulher do engenheiro, vivendo em um bom bairro do Rio de Janeiro, ou a que usava as jóias da família Cercal, são no fundo humilhadas por terem feito parte de um acordo sócio-econômico onde não havia lugar para ilusões amorosas. Elas faziam parte de uma hierarquia em que possuíam papéis secundários, não tendo esperanças de grandes afetos e tendo que cumprir um conjunto de regras. Elódia Xavier ${ }^{142}$ explica como funcionava o processo da família e do matrimônio em meados do século $X X$ :

A própria família conjugal moderna só pode ser bem compreendida a partir da origem patriarcal; a família era, então, necessariamente, o grupo dominante no processo de socialização, grupo onde as distâncias estavam rigidamente marcadas e reguladas pela hierarquia. $\mathrm{O}$ casamento, contrato sócio-político-econômico, não pressupunha afinidades afetivas nem sexuais. (XAVIER, 1998, p. 113)

O conflito de viver um casamento baseado no acordo social, marcou durante anos a vida das mulheres. Por esse motivo também é um tema muito presente na escritura de autoria feminina, que retrata a estrutura da família patriarcal com todos os pesares que essa impunha à mulher casada. Vemos que nem Clarice e nem Maria Judite estavam alheias a tal inquietude, contrariamente, evocaram o tema em várias de suas obras.

Os conflitos do casamento e a crise da família patriarcal são malogros que acompanham as personagens das escritoras, sendo temas dominantes nas narrativas de Os laços de família, e estando também presente na maioria dos contos de Flores ao telefone. Segundo Xavier, a justificativa para tais abordagens encontra-se no meio social, e na necessidade de denunciar o próprio silêncio:

É extremamente significativa a presença do espaço familiar nas narrativas de autoria feminina; os motivos parecem óbvios: sofrendo a mulher, de forma mais aguda, os efeitos repressivos do processo de socialização, processo este primordialmente familiar, o texto produzido por mulheres traz a marca dessa repressão. (XAVIER, 1998 p. 116)

\footnotetext{
${ }^{142}$ XAVIER, Elódia. Declínio do patriarcado: A família no imaginário feminino. Rio de Janeiro: Editora Rosa dos Tempos, 1998.
} 
Tanto Catarina quanto a protagonista juditiana evidenciam o conflito entre destino/liberdade, transgressão/aceitação, mas os seus gestos de ruptura geralmente ou são falhos, ou causam desafetos indissolúveis. O que no conto clariceano exemplifica-se no desconforto de Catarina com o marido e com o filho, nos gestos desencontrados com a mãe, ou ainda no choque que de repente tem diante de seu mundo: $\mathrm{E}$ de tal modo haviam-se disposto as coisas que o amor doloroso the pareceu a felicidade. (OLF, p. 122).

Já para a personagem juditiana tal efeito reflete-se em seu desconforto na presença do filho, a imagem séria do menino a faz crer que era impossível vencer o abandono que ela não sabia justificar. E que não era mais possível um afeto maior entre eles: Com o Eugênio eu nunca sabia até onde podia ir, como podia ir. (CAF, p. 123).

Muitas são as convergências que encontramos ao compararmos as duas protagonistas, seja na estrutura familiar, ou nos conflitos interiores. No entanto a maneira como vivem dentro de tal estrutura e como reagem a seus conflitos é uma das características que se desenvolvem no viés das convergências. Embora haja diferentes níveis de transgressão entre Catarina e a protagonista juditiana, observamos que, nem uma e nem outra conseguem romper com os "laços da condição".

Ao deixar o casamento para viver uma suposta paixão, a protagonista de "Carta aberta à família" dá a impressão de que assumirá as rédeas de seu destino e que decidirá como viver após sua partida. Porém a mulher que alguns anos depois escreve sua carta-confissão, não possui paixões nem esperanças e está cada vez mais sozinha. Quando pensamos se tratar de Lilith, vemos que de fato ela se aproxima bem mais de Eva. Não parece arrepender-se, por que não desejava a vida com o marido, mas por outro lado não suporta a vida que leva em seu minúsculo quarto de mulher solteira.

Sabemos que a paixão que a fez transgredir não parece ter conservado alguma importância para a protagonista, mas o envolvimento amoroso teve sua significação enquanto motivo que a desperta para os conflitos interiores, encorajando-a 
a fugir da própria condição. Assim, o mero caso que teve pode ter sido o caminho para entender o próprio eu, pois como nos explica Lou Andréas-Salomé:

Se alguma coisa existe capaz de conferir um significado até a mais medíocre das vidas femininas, é o fato de ela ter, em cada novo caso, de retomar desde a origem o conflito de sua vida interior; e de o resolver por sua própria iniciativa. (SALOMÉ, 2005, p. 100)

A contradição é um ponto forte que acompanha tanto a protagonista juditiana quanto Catarina. As duas mulheres anseiam por uma liberdade, por romperem com a vida e com os padrões impostos pela condição de mulher casada. Mas ao se encontrarem diante da possibilidade de um destino mais livre, perdem-se num sem rumo de solidão e incertezas. A mãe de Eugênio fadiga-se da própria solidão e os únicos sentimentos eu lhe restam são a angústia e o desejo de morte.

O universo da protagonista clariciana não é muito diferente. Ao sair com o filho sente-se perdida, e pára na esquina da rua, sem rumo, o que assinala seu estado de dependência, somando-se à falta de um lugar para si. Estas são características que reforçam a contradição que habita o feminino, instaurando-se muitas vezes como um duplo eu, ou na crise enraizada no binômio destino/liberdade, como visto na trajetória das personagens acima.

Porque de fato o conceito de mulher recobre, decomposto em traços particulares, as qualidades mais inconciliáveis, sem que seja necessário procurá-las muito longe: a mulher é sempre a contradição encarnada, na medida em que, de acordo com sua vocação criadora, transporta em si a própria vida, que nela vai operando. (SALOMÉ; 2005: 101)

O processo de rompimento e a crise dos afetos estão presentes nos dois enredos, e enfatizam uma presença em comum: a do filho, este que deveria ser o alvo da esperança ou a concentração dos laços familiares e maternos, é um tanto indiferente e distancia-se cada vez mais da presença da mãe. Catarina e o filho, mesmo quando rompem o ambiente da casa, não estão juntos, e vistos de cima são apenas figuras que se aproximam como em uma pintura: "Vistas de cima, as duas 
figuras perdiam a perspectiva familiar, pareciam achatadas ao solo e mais escuras à luz do mar. Os cabelos da criança voavam..." (OLF, p. 125).

A mãe de Eugênio também não se reconhece na figura do filho. Os discursos são desencontrados e os olhos do menino estão voltados para uma direção que a mulher não consegue, ou não quer, atingir. A frieza do menino depara-se com o silêncio da mãe, sempre presa a sua partida e ao abandono, erguendo um muro intransponível entre ambos. É a voz narrativa que descreve toda a intensidade da crise de afeto e da ausência dos laços familiares, colocando-os em momentos como se fossem dois estranhos:

"Sentes a minha falta?"

A pergunta saíra quase sem dar por ela. Uma ave quieta, bem escondida e que, de repente, se escapara da gaiola. O filho tinha-a olhado atentamente, como que surpreendido. Era uma pergunta insólita aquela, exageradamente pessoal, quase descabida.

"Não compreendo, mãe" (CAF, p. 128).

As duas mulheres, separando-se ou apenas indo para a rua sem rumo, são fugitivas de sua condição, sustentam no ato de fugir a ilusão de serem livres, de transgredir. Mas o peso da conduta que lhes é imposta, é mais forte e, ou as faz voltar, ou thes torna a vida insuportável. Mesmo os momentos de perigosa revelação não conseguem vencer a crise do dever a cumprir, e romper com este sistema é viver no insustentável.

A voz das autoras é também um exemplo da crise por sentir-se dividida entre papel social e transgressão, juntamente com a dificuldade de the dar com o desejo da escrita e a necessidade de exercer um papel muitas vezes limitador, tirando da mulher o direito de ser ela mesma. Tal situação semelhante a que descreve Elódia Xavier a respeito de algumas escritoras do século XX:

Percebe-se, às vezes, uma certa nostalgia pelo modelo familiar tradicional, onde as mulheres embalavam tranqüilamente seus filhos à sombra das árvores. O preço pago pela transgressão ao sistema é alto demais. (XAVIER, 1998, p. 118) 


\section{Tecendo por trás do real: a loucura assistida}

A loucura, longe de ser uma anomalia, é a condição normal humana. Não ter consciência dela, e ela não ser grande, é ser homem normal. Não ter consciência dela e ela ser grande, é ser louco. Ter consciência dela e ela ser pequena é ser desiludido. Ter consciência dela e ela ser grande é ser gênio.

Fernando Pessoa

Temos exemplificado, desde o início do presente estudo, várias manifestações de transgressão presentes nas várias histórias de mulherespersonagens, que até agora vimos. Trataremos nesta última parte das análises de uma outra face assumida pelas personagens "transgressoras": a loucura. Este estado implicará na ilusão de um rompimento com o mundo e a realidade que incomoda.

A loucura pode ser definida como desobrigação com o real ou negação do mundo ao redor. Porém no universo feminino, ao qual ela estará aqui atrelada, funcionará como uma espécie de saída, rompimento com a condição e com o papel social. Podendo ser um caminho para desatar-se da vida real que, até a segunda metade do século $X X$, é considerada uma espécie de prisão, como vemos na vida das mulheres de classe média, presentes nas narrativas de Clarice e Maria Judite.

Ao passar das mãos de um pai ou irmão para as de um marido, como citamos anteriormente, era amputado à mulher o direito de tomar parte ativa na sociedade $\mathrm{e}$ percorrer a vida como sujeito. Durante muito tempo, as mulheres que não se comportavam como mandava o manual de "boa conduta" eram chamadas de loucas. As que transgrediam deveres sagrados, como o casamento ou a maternidade, deveriam receber sérios "cuidados", sendo inclusive, como explica Magali Engel, "submetidas a um conjunto de medidas normatizadoras extremamente rígidas que assegurassem o cumprimento do seu papel social de esposa e mãe"143.

${ }^{143}$ ENGEL, Magali. "Psiquiatria e feminilidade". In História das mulheres no Brasil. Org. Mary Del Priore. São Paulo, Contexto-Unesp, 2004, p. 332. 
A forte pressão para aceitar as rédeas de um comportamento pleno de restrições obrigava as mulheres, sobretudo as casadas ${ }^{144}$ a seguirem parâmetros que iam de encontro a sua liberdade de ser humano, criando nelas a necessidade de negar a realidade ou sair dela para poder suportá-la. Para tentar desviar-se de tais obrigações as mulheres apelam para o que Freud" ${ }^{145}$ denomina "substituição do instinto", evasão que as levaria a buscar saída na arte, na escrita, no que estivesse fora do restrito campo do cotidiano, para assim não se entregarem totalmente à passividade a elas atribuída tanto pelo social quanto pelo psicológico:

Poder-se-ia considerar característica psicológica da feminilidade dar preferência a fins passivos (...) Devemos, contudo nos acautelar nesse ponto, para não subestimar a influência dos costumes sociais que, de forma semelhante, compelem às mulheres a uma situação passiva. (FREUD, 1976, p. 143).

O rompimento com a realidade levaria à evasão de comportamento: a loucura como maneira de ganhar a liberdade. No entanto esta poderia tornar-se uma ação perigosa, levando ao estado de isolamento e crise diante do seu mundo. A associação da loucura feminina à opressão social, só começou a ser enfatizada a partir do final do século XIX, com os estudos psicanalíticos de Freud. A partir de então começaram as associações da necessidade de refúgio à opressão causada pelas regras impostas à mulher pela sociedade patriarcal. Foi somente no início do século XX que "passou-se a conhecer algumas das razões familiares e sociais que levavam ao estado de desequilíbrio entre os sexos, resultando no domínio patriarcal da mente e do corpo femininos." ${ }^{146}$

\footnotetext{
${ }^{144}$ Em Portugal, no séc. XVII, D. Francisco Manoel de Melo escreveu sua Carta de Guia dos Casados (1651), uma espécie de manual para o casamento, com conselhos que reafirmavam a superioridade do homem e a subalternidade da mulher. Ver PIRES, José Cardoso. Cartilha do Marialva, ou das negações libertinas. Portugal: Moraes Editores, 1970.

${ }^{145}$ FREUD, Sigmund. "Feminilidade". In Edição Standart das Obras Psicológicas Completas de Sigmund Freud vols. XXI e XXII. Rio de Janeiro: Imago, 1976.
}

${ }^{146}$ DE LA ROCQUE, Lucia \& HARRIS, Leila. "A loucura feminina: enfermidade e/ou pressão social? Análise da questão nas literaturas contemporâneas de língua inglesa". Palestra integrante do Curso A VOZ E O OLHAR DO OUTRO, ministrado durante a VII Semana Interdisciplinar de Estudos Anglo-Germânicos, Faculdade de Letras da UFRJ. Rio de Janeiro, 30/11 a 3/12/ de 1998. 
Junto ao desejo feminino de viver em outra realidade surgem as manifestações de luta pela liberdade, a tentativa de contrariar o caminho estabelecido pela sociedade. Traços que foram fazendo com que o homem pensasse que o melhor para mantê-la "protegida" era interditá-la como louca, e assim limitar seus questionamentos e tentativas de subversão.

Por esta trajetória chegamos ao fato de haver um grande número de mulheres que, nas décadas de 50 e 60 do século passado, mesmo presas em asilos não apresentavam um diagnóstico conciso que pudesse afirmar seu desvario. Tratava-se muitas vezes de senhoras casadas que ousavam contrariar as leis criadas e sustentadas pelos maridos. Eram atestadas como loucas e quanto mais tentassem provar ao contrário, agir em prol de si mesmas, mais sucumbiam nos isolamentos como alienadas ou dementes.

Não é por acaso que também nos anos de 1960 veremos aparecer um grande número de obras de autoria feminina tendo como marca comum o tema da loucura. As personagens são mulheres que "enlouquecem", ou que optam por negar o real pela alienação. Sofrem ao se conscientizarem de que perderam sua identidade individual, e que existem apenas como donas de casa, esposas ou mães. Segundo Phyllis Chesler a loucura é muitas vezes para a mulher uma espécie de fuga rumo à transgressão, ou ainda se constitui como a única saída da opressão social: "une telle folie est essenctiellement l'experience intense de la castration biologique, sexuelle et culturelle de la femme, et une recherche condamnée de la puissance"147(CHESLER, 1975, p. 45).

Segundo Chesler, a maior parte das mulheres que até a segunda metade do século XX são internadas como loucas, nada têm além de um desejo mais forte de exercer seu papel de sujeito, de não se submeter e de ter em mãos seu destino. Do ponto de vista do papel social feminino, a negação da realidade pela loucura, é uma ruptura, e uma maneira de existir à margem dos rígidos padrões de conduta ainda vigentes na época. Tal postura à margem dará à mulher a condição de exilada, características tão bem exemplificadas nas narrativas de Clarice e de Maria Judite.

\footnotetext{
${ }^{147}$ CHESLER, Phyllis. Les femmes et la folie. Trad. J-P. Cottereau. Paris, Payot, 1975. (Tal loucura é essencialmente a experiência intensa da castração biológica, sexual e cultural da mulher, e uma busca condenada de poder).
} 
Conforme já mencionado anteriormente, dentre as mulheres resistentes ao sistema patriarcal, estavam muitas escritoras, para as quais a literatura era também uma forma de protesto. Estas mostravam através de suas personagens todo o malogro da condição feminina, e o resultado da opressão era muitas vezes a evasão em um mundo "alienado" na loucura, como forma de negar a realidade para torná-la suportável.

Na segunda metade do século $\mathrm{XX}$, cresceu ainda mais o número de obras através das quais suas autoras se manifestavam contra a condição social da mulher. Aquelas que conseguiam se fazer ouvir, através da literatura, davam voz a tantas outras que se calavam, possibilitando a discussão sobre problemas há tantos anos silenciados.

Ao aliar a literatura às questões sociais nos aproximamos do que defende Antônio Candido, em seu estudo sobre literatura e sociedade: "a literatura é também um produto social, exprimindo condições de cada civilização em que ocorre" (CANDIDO, 2000, p. 19) Tal relação ocorre também através dos fatores de integração e de diferenciação, integração como conjunto de fatores que tendem a acentuar no indivíduo ou no grupo a participação nos valores comuns da sociedade. A diferenciação, ao contrário é o conjunto dos que tendem a acentuar as peculiaridades, as diferenças existentes entre uns e outros.

O enfoque da loucura, na escritura de autoria feminina, chama a atenção para o muro que separa as personagens de uma sociedade da qual não tinham direito de participar. Tornando-se um motivo a mais de exílio e de vida para fora das relações sociais, como veremos mais a diante nas personagens de Clarice e Maria Judite.

Vemos em vários momentos da história feminina que o estado de alienação aponta para a intensa necessidade de recriar um mundo ilusório, sem o peso dos dias que se resumiam em cumprir deveres. Assim a loucura feminina que acompanharemos através das obras analisadas, será conceituada como uma transgressão do real, ruptura com o papel social. No entanto é necessário, a princípio, buscar saber quem é de fato essa que se sente obrigada a trocar a razão pela liberdade. 
A mulher tem sido impregnada de limitações e obrigada a enquadrar-se em um retrato social que se construiu opressor. Fazendo-a cumprir determinados papéis, através dos quais deveria ser frágil, bonita, e submissa, e fugir a isso seria perder seu lugar social. Por isso as que se arriscavam sabiam estar em caminho perigoso. Abrir os olhos de ver, vendo-se a si e ao limitado mundo a que era submetida, fazia-lhe por vezes mergulhar em profunda angústia, e posteriormente no desejo de despir-se da realidade.

Magali Engel parte das diferenças do papel social entre masculino e feminino, para definir a loucura das mulheres como sendo "subversão/inversão das normas e regras socialmente estabelecidas, avesso da ordem". E o alienado "seria aquele que não tem habitualmente consideração por nenhuma regra" ${ }^{148}$. O trecho citado nos reporta à necessidade das personagens femininas de Clarice e Maria Judite em romper com seus padrões. Conseqüentemente surge o choque de deparar-se com o conflito entre o desejo da liberdade e o esforço para cumprir as regras de um viver "tranqüilo" dentro do pequeno espaço da condição e da dependência do outro.

Geralmente, a mulher levada aos cuidados psiquiátricos pelo marido e apontada como perigosa, era apenas alguém com anseios de pôr a vida pessoal à frente da condição social que a obrigava a criar uma família. Ou aquela que pensava buscar a si mesma sem precisar empenhar-se totalmente no cuidado com marido e filhos. Algumas vezes tratava-se apenas de uma "mulher para quem o projeto de estudar era mais importante (ou mais urgente) do que o de tornar-se mãe" (ENGEL, $p$. 1998: 570). No entanto não the era reconhecido esse direito, e insistir seria admitir-se transgressora, louca e egoísta, já que não fora criada pra pensar em si, mas para viver e ver-se apenas em relação ao outro.

A solução para controlar a vítima da subversão era trancá-la em um asilo, descrito por Hélène Cixous ${ }^{149}$ como um lugar-prisão onde era segregada a mulher classificada como louca, havendo também as que permaneciam confinadas no espaço doméstico. A loucura da qual ela era acusada quase sempre se traduzia no desejo de seguir um destino que não fosse o estabelecido pela sociedade. Seu desvario é insistir

\footnotetext{
${ }^{148}$ ENGEL, Magali. “As fronteiras da anormalidade: psiquiatria e controle social”. In História, Ciências, Saúde Manguinhos, v. 3; nov. 1998-fev. 1999, pp. 547-563.

${ }^{149}$ CIXOUS, Hélène. "L'ordre mental”, prefácio do livro La femme et la folie. Bibliografia já citada.
} 
na vontade de ser livre, o que ia de encontro com o destino de alguém que deveria exercer um papel em prol da família e do bem estar do outro. De tal confinamento só era possível sair com a ordem de um homem, pai ou marido, a mãe ou irmã não teriam jamais autoridade para tirá-la de lá, o que explica a pouca confiança depositada no sexo feminino.

Podemos então dizer, seguindo a argumentação de Cixous, que a mulher era condenada à loucura não sendo exatamente portadora de uma anomalia neurológica. Muitas vezes, o motivo era apenas a manifestação de suas sensações, ou reivindicação de seus direitos, ação incompatível com a personalidade que the era recomendada. Impulsos incontroláveis e arroubos de reflexão eram suficientes para que a mulher devesse ser isolada, uma medida que consistia em não prejudicar outras, as mais dóceis que por comodidade ou por medo resolviam aceitar a submissão. A louca seria então a vilã, culpada, mulher condenável por sua insatisfação e revolta incabíveis para sua condição. Segundo Cixous, essas mulheres eram de fato pessoas "mal insérées dans le champ du désir". (CIXOUS, 1975, p. 9)

No universo das personagens femininas das escritoras brasileira e portuguesa, o conflito interior se traduz também no binômio subverter-inverter, ainda que haja apenas vontades e buscas sutis para estar fora das leis sociais. As regras e deveres são repetidamente executados pelas protagonistas, mesmo que de maneira cega e superficial, pois o desejo de ambas anda de fato por caminhos aquém de tudo que "devem" fazer, por isso a necessidade de saída para uma realidade inventada, que se constrói como possibilidade de ultrapassar muros da rotina limitada.

A loucura como transgressão surge também como conseqüência da necessidade de descobrir-se autora de si mesma, o que geralmente é o sentimento primeiro nas personagens femininas depois de um olhar novo sobre o universo que está ao seu redor. A essa necessidade podemos aliar o convite de Simone de Beauvoir para a construção de um sujeito feminino que se faça à revelia daquele traçado pelo homem. Elencando desde a ascensão a uma vida política até uma educação que não mais fosse relativa ao homem. Este seria o caminho para "o ser livre", rompendo com a inexistência social a mulher poderia diminuir sua dependência, uma vez que: 
Le privilège economique détenu par les hommes, leur valeur sociale, le prestige du mariage, l'utilité d'un appui masculin, tout engage les femmes à vouloir ardemment plaire aux hommes. (...) II s'ensuit que la femme se connaît e se choisit non en tant qu'elle existe pour soi mais telle que I'homme la définit ${ }^{150}$. (BEAUVOIR, 1949, p. 254)

A escritora e ensaísta francesa propõe à mulher romper com todo o legado anterior e mudar de lugar social, assim como denunciar séculos de uma vida à margem, fruto da submissão, e propor uma nova posição do feminino que o retire da condição de sombra do sujeito masculino. É um rompimento que de certa forma também pode ser considerado loucura pelas leis de conduta do feminino. As colocações feitas por Beauvoir além de, como já dissemos, influenciarem bastante a literatura a partir dos anos 60 , foram recebidas por muitos como transgressoras e um atentado ao papel social do "sexo frágil", e sua construção:

On ne naît pas femme: on le devient. Aucun destin biologique, psychique, économique ne définit la figure que revêt au sein de la societé le femelle humaine: c'est l'ensemble de la civilisation qui elabore ce produit intermédiaire entre le mâle et le castrat qu'on qualifie de féminin. ${ }^{151}$ (BEAUVOIR, 1949, vol. II, p.13).

A dificuldade de caber entre o mundo dos homens e mesmo o das mulheres, o conflito de sentir-se fora, inclassificável são características que vemos nas personagens de Clarice e Maria Judite. As narrativas comparadas a seguir trazem em comum também um pouco do quadro já apresentado na parte referente ao trabalho doméstico e ao cotidiano das mulheres casadas. A casa será o espaço de confinamento das protagonistas, e na atmosfera familiar é que se desenvolverão seus devaneios. No entanto haverá de certa forma um dado novo: o homem vai ganhar um espaço mais marcante nos enredos aqui comparados, nunca como positivo para a conduta da mulher, mas agora mais atuante do que nos enredos percorridos

\footnotetext{
${ }^{150} \mathrm{O}$ privilégio econômico de posse dos homens, seus valores sociais, o prestígio do casamento, a utilidade de um apoio masculino, tudo compromete a mulher a querer profundamente agradar aos homens (...) O que se sucede é que a mulher se conhece e se coloca não tal qual ela existe por si mesma, mas segundo o homem a defini.

${ }^{151}$ Não se nasce mulher: torna-se mulher. Nenhum destino, biológico, psíquico, econômico define a forma que a fêmea humana assume no seio da sociedade; é o conjunto da civilização que elabora esse produto intermediário entre o macho e o castrado que qualificam de feminino.
} 
anteriormente, o que se justifica alguns parágrafos acima quando nos referimos ao fato de a loucura da mulher ser sempre apontada pelo marido, ou em função deste.

\subsection{A casa sitiada}

De súbito há algo estranho, o que? Não sei mas pressinto o que quer que seja de imponderável e altamente perigoso a avançar, a aproximar-se, a chegar até mim.

Maria Judite de Carvalho

Uma mulher tentando reorganizar a disposição dos móveis, é a cena inicial de "O aquário", narrativa juditiana. A protagonista, recém-saída de um asilo de loucos, insiste obsessivamente em reordenar os móveis para criar um novo caminho entre eles, reconstruindo seu labirinto. As ações são desenvolvidas como execução necessária para amenizar um conflito latente na personagem. O princípio do choque vem com a quebra repentina da estátua que ficava em um canto da casa: "O busto cor de ardósia da rainha Nefertiti caiu e fez-se em pedaços porque era de barro pintado. Ainda bem. Irritava-a aquela carinha impermeável sem olhar lá dentro" (AO, p. 103).

A destruição do busto causa certo mal estar que a protagonista procura esconder entre os movimentos rápidos da arrumação, finge alegrar-se por haver desmascarado aquela fragilidade com aparência de força. No entanto a aparente estabilidade da estátua compara-se à atmosfera de tranqüilidade que a personagem tenta criar ao seu redor, porém tudo está muito frágil em volta da sua vida de mulher "bem casada", que pode se quebrar a qualquer momento:

Afastou os cacos com o pé, quase raivosamente, e, em seguida, recuou uns passos e observou a escrivaninha com um lento olhar crítico. Melhor não ficava. Enchia mais a sala, tinha-se mesmo certa dificuldade em passar. Era preciso dar uma pequena volta a contornar o móvel, desenhando um arco de círculo. Já não se podia entrar à pressa, em linha reta, sem olhar para os lados. (OA, p. 103) 
As paredes da sala verde-água e os móveis arrumados em arco de círculo vão dando o tom de um grande aquário, que a protagonista observa pensativa. Seus olhos se fixam sobre a nova imagem de seu espaço. A voz narrativa, confundindo-se com a reflexão da personagem, denuncia-nos que a constante mudança na posição dos móveis é uma prática quase obsessiva utilizada por ela para mudar a aparência de seu pequeno mundo doméstico. Criar novos caminhos, e dar a impressão de um lugar desconhecido, mas que acaba por resultar em nada, e logo tudo volta a ser igual ao que era dantes: familiar e perigoso.

E tornar-se-ia necessário mudar qualquer outra coisa. Talvez o aparelho de rádio, era uma idéia. Podia perfeitamente pô-lo em cima da mesa redonda. Ou levar o fauteuil para perto da janela. Ou trocar o sentido norte-sul do sofá por este-oeste. Ou até no próprio quarto... Havia um sem-números de combinações a estudar. Mas por enquanto era cedo. (OA, p. 104)

Então vemos que através dessas mudanças a protagonista busca evitar as repetições e os perigosos caminhos da mesmice, a aparente renovação do espaço cria a ilusão de fuga de um cotidiano limitado pela vida branda. A necessidade de organização do espaço externo permite a ela desviar-se dos conflitos interiores, por isso a insistência no movimento diário de mudança, mesmo sabendo que "tudo voltaria à mesma, tudo seria igual ao que era dantes. E tornar-se-ia necessário mudar qualquer outra coisa". (OA, p. 103).

A mulher busca dificultar as idas e vindas dentro da casa como se construísse aos poucos o próprio labirinto. Tornando o familiar estranho, ela parece querer sempre construir um espaço de passagem, como se tentasse mudar o aspecto de lar com sua falsa tranqüilidade. Segundo Bachelard, o espaço da casa relaciona-se com a idéia de abrigo e segurança: "sabemos bem que nos sentimos mais tranqüilos, mais seguros na velha morada, na casa natal, que na casa das ruas que só de passagem habitamos" (BACHELARD, 2000, p. 59). Então a mudança do espaço quebraria, tal como a estátua, o ritual de normalidade que a personagem deveria cumprir diariamente. 
Vemos então que na luta travada com o espaço, há uma ansiosa busca por equilíbrio, impondo-se na rivalidade entre o interno e o externo, na dúvida em "trocar o sentido norte-sul do sofá por leste-oeste". No entanto a temida repetição está presente na pergunta e resposta repetidas constantemente pelo marido e pela mulher a respeito da própria felicidade:

Dificuldade em acordar (acordar não, trocar uma coisa por outra coisa, já velha, já gasta, já vivida), dificuldade em repetir pela milésima vez que sim, que era feliz - em dias excepcionais achava-se mesmo na obrigação de dizer que era muito feliz" -, em sorrir (era preciso que sorrisse), depois em gastar o dia - tão longo - caminhando por ele fora e fugindo cuidadosamente às armadilhas, em sorrir outra vez quando ele, no regresso, Ihe perguntava se era feliz. Dificuldade em dizer outra vez que sim (OA, p. 104 - grifo da autora).

As tantas dificuldades de caminhar dentro da normalidade decretada pela vida de casada desencadeiam a necessidade de fugir cuidadosamente a uma rotina de armadilhas da rotina. Assim ela tentava construir em torno de si uma aparência que possa responder à pergunta diária do marido sobre a mesma felicidade da qual ela também precisava se convencer. A figura do marido é de guardião e condutor da normalidade da mulher e da família, tentando regrar a existência da mulher e fazendo sempre a mesma pergunta para certificar-se da resposta, para manter a ligação dela com o equilíbrio de uma vida simples e domesticada. Assim assegurava-se da felicidade que, mesmo assistida e imposta, era verbalizada todos os dias para enganar a própria alma:

Era um círculo vicioso e necessário, tão necessário como a própria vida. Dir-se-ia que ele não podia sair de casa pela manhã sem ver onde ficavam os pensamentos e as palavras dela, nem entrar à noite sem verificar se estavam no mesmo sítio onde os deixara, dobrados e passados a ferro dentro da gaveta. (OA, p. 105)

Uma das preocupações da protagonista era a de não se deixar sair do lugar onde o marido a deixava todas as manhãs, sondando-lhe sempre os pensamentos para saber se continuavam arrumados, e assim assegurar-se da "lucidez" de sua mulher. O homem, neste enredo como em tantos contos de Maria Judite, representa o 
freio das divagações, o "bom senso", ou ainda aquele que "reorganiza" o que está fora de lugar, garantindo a paz do lar. É para mantê-lo calmo, que ela acostuma-se às respostas afirmativas, a fazer de suas reflexões e anseios sentimentos insignificantes:

Havia nesses momentos, durante aquela pergunta aparentemente natural, feita mesmo com excessiva naturalidade e até com desinteresse pela resposta, como que uma impressão passageira, que logo esmorecia, se apagava, mergulhava no lago profundo e baço. E ela não deixava de sorrir" (OA, p. 105)

A tentativa constante da protagonista em mudar o ambiente em torno de si mesma a faz empregar seus dias em novas estratégias de mascarar um confinamento, renovando também a própria imagem. Segundo Bachelard a renovação do espaço pode alterar também a visão de mundo do ser: "a fenomenologia da imaginação exige que vivamos diretamente as imagens, que as consideremos como acontecimentos súbitos da vida. Quando a imagem é nova, o mundo é novo" (BACHELARD, 2000, p. $63)$.

Dentro da imagem diária que a protagonista compõe em volta de si, a casa é o lugar onde se alojam alegrias e tristezas, onde desenha a própria personalidade da mulher, por isso a tentativa de dar ao espaço sempre a idéia de presente, de novo, tirando vestígios de si mesma. Retirar constantemente os objetos de onde estão retrata também sua desordem interior, e a intenção de dificultar a busca de si mesma no espaço, pois de fato "parece que a imagem da casa se torna a topografia de nosso ser íntimo" (BACHELARD, 2000, p. 64).

A casa para a protagonista não é apenas o espaço doméstico, mas parece ter um sentido maior de confinação. Voltamos a um detalhe importante do início do conto: as paredes de cor verde-água, o espaço em círculo e o recolhimento silencioso da mulher nos remetem ao título da narrativa. Ela está presa em um aquário íntimo, que parte de seu interior para o espaço interno da casa, está aprisionada na própria vida. A situação de confinamento se acentua no momento em que seu olhar encontra o espelho, este a fará perceber toda a superficialidade do sorriso que maquinalmente se pregara em seu rosto durante o choque de se ver aprisionada em si mesma: 
O espelho quadrado lançou-lhe em rosto o sorriso de agora que the surgiu maquinalmente na boca. O fim da tarde dava uma estranha profundidade às coisas e ela era simplesmente uma coisa, uma imagem qualquer apagada, a boiar na escura transparência das águas tristes e solitárias do seu aquário pessoal. Os outros passam e olham, lêem o nome, seguem adiante, já se esqueceram. Pagaram seu bilhete à entrada, podem parar e ler o nome. E seguir adiante. E esquecerem-se. Podem fazer isso tudo. (OA, p. 105)

O momento de confronto com o espelho é também o de revelação, no qual a protagonista é vista em duas perspectivas: de fora e de dentro do aquário. A mulher assiste à própria condição, e a força de tal imagem a atinge cruelmente, destruindo seu equilíbrio moldado pela arrumação dos móveis. O instante do reconhecimento é de grande importância, e resulta na desestrutura do eu, desestabilizado com o mundo.

$\mathrm{O}$ olhar revelador lançado sobre si mesma mostra-lhe um peixe que dentro de um aquário é admirado por quem passa, nada mais é que uma atração. A estagnação diante de tal imagem interrompe seus movimentos entre os móveis, é a fatalidade que a retira do espaço onde de fato ela nunca estivera. A profundidade com que a realidade se ilumina diante de seus olhos é quase insuportável, no entanto a visão de si mesma tão de frente, tão clara a impede de fugir como sempre havia feito:

Estava sozinha de bilhete na mão, a olhar para si própria dentro da montra de água onde se exibia para seu próprio regalo. Regalo? Era um espetáculo fascinante a que ela fugira sempre que possível. Qualquer pretexto era bom. Precipitara-se sobre o livro que começara a ler e não tinha sido capaz de continuar (...) Agora, porém, deixou-se ficar para trás, distraída e foi apanhada na armadilha da sua própria imagem. Já não podia fugir. Estava amarrada de pés e mãos. (OA, p. 105)

As descobertas diante do espelho revelam os malogros da protagonista, que são também os mesmos da mulher juditiana. O mais forte deles é a solidão, ela percebe-se só, incapaz de viver dentro de uma casa arrumada com seu mundo interior em frangalhos. A saída será negar-se a essa realidade, fugir do papel social pela inconsciência da realidade, ela então decide quebrar a normalidade que vinha tentando construir todos os dias e assim libertar sua existência na loucura de não pertencer a mundo algum. 
Este movimento no interior da personagem pode também ser visto como uma fuga, mas que se difere das que citamos no capítulo anterior, aqui não há saída por uma porta ou janela, e sim um mergulho em si mesma, sem importar-se com a razão. Quebrando-se para tentar sobreviver e enfrentar a própria falência, o que nas palavras de Benilde Caniato é um traço de união entre essas mulheres:

Assim nos parece que as Graças, as Marianas, as Joanas, dispersadas, em pedaços, revigoram-se em sua solidão para enfrentar as falências às quais estão condenadas irremediavelmente. (CANIATO, 1996, p. 86)

O espelho transforma sua consciência e também sua fisionomia, ela se mistura à água turva do aquário, vê-se em sua prisão, tenta fugir, mas as fugas são circulares, não rompem as paredes do aquário. Ela nunca rompera com nada de fato, sua ilusão de fuga fora apenas uma justificativa que dava a si mesma, como a loucura que ela mantinha entre seus muros. Tais evidências nos são apresentadas através de uma retroação no tempo, em que a voz narrativa resume o passado da protagonista, seu desconforto e falta de jeito a fizeram sempre fugir de um mundo onde se sentia incompreendida:

Nunca ninguém compreendeu porque ela fugia. Da escola, de casa, de toda a parte. Uma coisa tão simples, afinal. Mas não. As pessoas não eram capazes de compreender. Olhavam-na desconfiadas, como se ela...Era como se falassem outra linguagem...Falavam outra linguagem. (OA, p. 106)

A incompreensão é uma das principais dificuldades enfrentadas pela protagonista e que tem como conseqüência sua sensação de exilada. A dificuldade de ver-se em relação aos outros é expressa pelo narrador ao descrever a reflexão da mulher diante do espelho. $O$ discurso é fragmentado pelas reticências denunciando a delicadeza do momento e a quase impossibilidade de admitir-se fora da realidade. Diferente das outras vezes, ela não consegue fugir, está "amarrada de pés e mãos", e nem mesmo o espaço da casa consegue salvá-la desse mergulho em seu interior.

O fluxo de consciência mostra a intensidade de sua reflexão, as frases reticentes vão configurando a mudança de estado pelo qual começa a passar a 
mulher. Seu passado se explica diante dela, porque tivera sempre de fugir do labirinto que era a relação com o outro. Tudo começava a esclarecer-se como num clarão, então entendemos junto com a personagem o porquê das constantes arrumações dos móveis, da tentativa de fazer da casa um labirinto onde ela enfim se perdesse:

E no entanto era tão simples, pois não era? Compreender que a certa altura as coisas deixavam de ali estar e que as pessoas iam morrendo à sua volta e que ela tinha de procurar outras coisas e outras pessoas vivas, porque senão... Senão... Por isso trocava tudo e compunha cenários novos. Para não ter de fugir outra vez. (OA, p. 106)

Juntamente com o espelho surge o momento do olhar mais intenso, com olhos penetrantes sobre si mesma, a protagonista amplia o universo a seu redor. Cresce a angústia como fruto do que é visto: a imagem refletida de seu eu, como nos explica Maria Judite em trecho já referido anteriormente: "Se você olhar em volta com olhos de ver, bem abertos, se se esquecer de si própria durante uns minutinhos...Meu Deus, o que você vê!" (CARVALHO, 2000, p. 73)

A trajetória da personagem está diretamente ligada ao espaço. A casa é um cenário existencial, onde ela (des)arruma seus conflitos, é também a proteção contra o espaço externo, contra a temida relação com o outro, com aqueles que falam "outra linguagem". Após o choque diante do espelho, é na observação do espaço que a mulher tenta buscar sentido:

A sala estava agora diferente. Tinha uma estante e uma escrivaninha e deixara de ter uma rainha Nefertite (...) Parecia mais pequena, tinha de se entrar em arco de círculo e não em linha recta (...) Mas daí a oito, a dez dias, já não seria assim porque as pessoas teriam decorado o caminho e ela seria então obrigada a mudar qualquer outra coisa. (OA, p. 106)

Ao aliarmos a casa aos objetos, observamos que eles se embaralham nos diferentes cantos da sala ou do quarto, sempre seguindo a forma do círculo. E circular também é o movimento feito pela protagonista em direção a si mesma: parte da observação do espaço para a reflexão interior. E então os móveis e os objetos ganham uma nova dimensão conforme o lugar que ocupam no espaço, a estátua que 
antes era provocativa com seus olhos inexpressivos torna-se apenas a marca de uma ausência. O que levará a protagonista a deparar-se com suas tantas ausências, como a de felicidade ou ainda há de um lugar para si no mundo, já que se acostumara a viver do que the cabia na existência do marido:

"Feliz?", perguntava-Ihe ele ao acordar e ao chegar a casa ao fim da tarde. E tinha aquele olhar ansioso enquanto ela o não sossegava. Cheio de medo, coitado, de ter de a levar outra vez àquela grande casa a que ele chamava hospital. Hospital! Coitado... (OA, p. 107)

A figura do homem é a representação do mundo real e bem explicado, é ele quem confronta diariamente a mulher com sua falta de felicidade, quem verifica suas idéias ao final do dia para confirmar se são as mesmas da manhã. É aquele que a conduz á grande casa, para reabilitar-se ao mundo real, ao convívio com a normalidade, e para tentar resgatá-la da fuga para longe da vida de mulher aprisionada pela condição.

A expressão "outra vez", no trecho acima citado, reforça a idéia de repetição, fator presente durante toda a narrativa e sob o qual se estabelecem as constantes arrumações no círculo dos móveis. Tais características nos levam a concluir que em "O aquário" temos várias etapas de uma circularidade na qual está inserida a protagonista. São círculos de suas reflexões, do espaço, do tempo, que comungam com os passos rumo ao "grande espelho" da vida, que se põe diante da mulher juditiana, levando sempre ao difícil encontro consigo mesma.

Antes de olhar para o espelho e de olhar para as mãos, tenho quinze anos. A minha cara é lisinha e uso os cabelos soltos. Depois olho para o espelho e reparo que tudo isso aconteceu há muito tempo, mas que é formidável eu estar aqui e não tão velha como tudo isso. E gosto de olhar para o espelho e de olhar para as minhas mãos. Penso que os quinze anos era uma idade incômoda e irrequieta e não gostaria de voltar atrás (...) Tive uma vida de mulher, que mais posso desejar? (CARVALHO, 1979, p. 82)

Após o encontro consigo vem a consciência de sua pequena existência sempre a se misturar aos móveis da casa, surge a inquietação e a transgressora ilusão de negar a realidade pela loucura. Para a protagonista, tal estado se traduz 
também no exílio necessário por não caber em seu papel, e por não se adequar a sua condição, o que a faz sentir-se incompreendida.

Foucault ${ }^{152}$, em seu amplo estudo sobre a loucura, define os que são separados em asilos como pessoas de "sensibilidade extrema", que se colocam como profundos espectadores da vida, eis porque esta os toca profundamente, a ponto de se tornar a eles uma ameaça: "Seguindo-se o fio dos registros, dir-se-ia que uma mesma sensibilidade os localiza, que um mesmo gesto os põe de lado" (FOUCAULT, 2004 , p. 110). Tal comportamento resulta em um certo desequilíbrio nos costumes, e até mesmo dificuldade em trafegar dentro do que todos chamam de normalidade. Esta sensibilidade estrema é o que leva a personagem de Maria Judite rumo a si mesma, e conseqüentemente ao afastamento do mundo ao seu redor.

Parada diante de si mesma, a personagem tem a visão alargada e oscila entre dentro e fora do aquário em que se resumem seus dias. $\mathrm{O}$ afastamento de si é também o caminho para dentro de si mesma, numa busca de se identificar na imagem refletida. É muito freqüente na escritura de autoria feminina a presença do espelho como revelação, o duplo olhar que surge desse embate leva a uma segunda imagem com a qual a personagem tenta se identificar. Na obra juditiana é elemento freqüente, podendo ser comparado à prisão do aquário:

Olha-se no espelho-quário como se procurasse no rosto a marca de mais uma semana de vida. Aquela ruga já ali estaria há oito dias, menos nítida, menos funda, ameaça, esboço talvez? (CARVALHO, 1979, p. 159)

Segundo nos explica Yannick Resch, ao se refletir no espelho a personagem feminina desencadeia pensamentos que muitas vezes simbolizam a projeção de um narrador, denunciando o estado de submissão da mulher. A outra imagem de si mesma refletida no espelho, causa os momentos de estagnação, revelando o ser ambíguo que habita o feminino. Ao nos transportarmos para a protagonista juditiana, podemos deduzir que o espelho é também o caminho para a busca de um eu perdido no outro ou na condição na qual ela se encontra, e que se esclarece cruamente na imagem refletida:

\footnotetext{
${ }^{152}$ FOUCAULT, Michel. A história da loucura na idade clássica. São Paulo: Perspectiva, 2004.
} 
Cependant la femme, lorsqu'elle n'a pas s'affirmer ou à rechercher dans le miroir l'assurance de son pouvoir et de ses forces, n'hésite pas à faire preuve d'un jugement critique vis-à-vis d'elle-même. Le miroir deviant alors l'instrument d'auto-critique du moi et sert de réflecteur au personnage qui découvre ses lacunes et ses défauts ${ }^{153}$. $(\mathrm{RESCH}, 1973$, p. 116)

Ver-se no espelho é também a possibilidade de ser observada como se por outro, dessa maneira a personagem é capaz de se distanciar da própria imagem e apreender-se melhor, como se passasse por outro para chegar a si. Tal característica se aproxima daquela que encontramos na definição clariceana sobre a trajetória em busca do eu:

Mas o atalho com sombras refrescantes e reflexo de luz entre as árvores, o atalho onde eu seja finalmente eu, isso não encontrei. Mas sei de uma coisa: meu caminho não sou eu, é outro, é os outros. Quando eu puder sentir plenamente o outro, estarei salva e pensarei: eis o meu porto de chegada. (LISPECTOR, 1994, p. 119)

Olhar de perto esse duplo de si mesma tem como conseqüência a intensidade das reflexões e as atitudes convulsas que farão com que a protagonista seja vista como alguém sem razão, para fora da realidade. A personagem acaba deixando-se novamente tomar pelo estado de loucura, sua reação estagnada diante do espelho explode em um riso incontrolável que se instala em seu rosto e "isso agitou a superfície tranqüila e rasgou a imagem em farrapos que ondularam à sua volta". (OA, p. 107). E no momento da nudez e da impossibilidade da fuga, a mulher se mistura e se desfaz como um pequeno peixe de aquário.

Todo seu eu se revela livre e preso ao mesmo tempo. Ela está diante da duplicidade: de um lado a mulher casada dedicada ao homem e à arrumação dos móveis; confrontando-se com a mulher distante do destino e entregue à liberdade, salva da realidade pela loucura. Está no centro de sua prisão interior, de onde enxerga seus malogros:

\footnotetext{
${ }^{153}$ No entanto a mulher, quando não tem que se afirmar ou buscar no espelho a segurança de seu poder e de suas forças, não hesita em se pôr à prova de um julgamento face-a-face consigo mesma. O espelho se torna então o instrumento de auto-crítica do eu, refletindo a personagem que descobre suas lacunas e seus defeitos.
} 
Devant le miroir le personage feminin s'interroge, s'admire, se critique. II n'a plus a porter le masque protecteur qu'il présent sous le regard d'autrui et peut chercher, dans l'image qui le refléte, sa véritable identité ${ }^{154}$. (RESCH, 1973, p. 114)

A conseqüência do encontro com o eu interior se reflete na necessidade de compor seus cenários novos, criar espaços circulares, pois para atravessá-los seria necessário mudar de olhar, o cuidado especial, como quem entra em um caminho desconhecido. A composição desse espaço de aparência impessoal compõe os passos rumo à constante busca da protagonista, vem disso a tentativa de evitar que tudo se torne parecido a ela mesma. Sua constante necessidade de mudança alia-se ao esforço para aparentar normalidade, deixam o marido como um vigia, sempre em alerta, preocupado e "cheio de medo, coitado de ter de a levar outra vez àquela grande casa a que ele chamava hospital". (OA, p. 107).

O medo é um sentimento freqüente em "O aquário", temos o temor da mulher tentando sempre dispor os móveis de forma a criar no espaço circular um labirinto, para fugir da domesticidade da casa. O medo do marido, sempre a espreitar a conduta da mulher e a questionar sua normalidade, este estado, ou qualidade como denomina Foucault, está diretamente associado à melancolia como tipo de loucura, que segundo o filósofo francês, pode ser chamado de loucura sem delírios e com certo limite, o que nos levaria a chamar de loucura assistida.

Os espíritos melancólicos descritos pelo filósofo muito se aproximam da espécie de melancolia que toma a protagonista do conto juditiano, uma agitação calma, convulsão de espírito que às vezes paralisa e em outras faz com que as ações sejam repetidas desordenadamente. O estado convulso é assim explicado por Foucault:

$\mathrm{Na}$ melancolia, os espíritos são arrastados por uma agitação, porém uma agitação débil, sem poderes nem violência: espécie de empurrão

\footnotetext{
${ }^{154}$ Diante do espelho a personagem feminina se interroga, se admira, se critica. Ela não tem mais que usar a máscara protetora que apresenta diante dos olhos alheios. A personagem pode buscar, na imagem que lhe reflete, sua verdadeira identidade.
} 
impotente que não segue os caminhos traçados nem as vias abertas. (FOUCAULT, 2004, p. 262).

Em seguida o autor afirma que o frenesi é breve, e que: "os espíritos não se perdem muito nos caminhos que traçam, sua agitação logo esmorece, sua força se esgota e o movimento se detém", a melancolia gera certo freio no estado de ansiedade: "a melancolia jamais chega ao furor; loucura nos limites de sua impotência" (FOUCAULT, 2004, p. 266). As definições do autor nos ajudam a entender a mudança que a protagonista sofre diante do espelho, a estagnação transforma-se em riso convulso e incontrolável, no entanto o riso mascara a melancolia de ver-se como pequeno peixe entre as estreitas paredes do aquário:

Riu-se, riu-se por ali fora, e no aquário o peixe já sem formas, quase apagado pela hora, diluído em noite, riu-se também, e isso agitou a superfície tranqüila e rasgou a imagem em farrapos que ondularam à sua volta. (OA, p. 107)

Sem buscar mais os fios do equilíbrio, ela se abandona diante do aquário, como o peixe a ocupar o espaço pequeno ao invés do mar, a mulher permanece em seu "aquário pessoal" paralisada pela condição de pequena e aprisionada "em seu exíguo metro cúbico de água turva". Conformidade e abandono de si são as características que o narrador juditiano nos mostra no quadro final do enredo, conformidade será também um sentimento forte no conto clariceano que analisaremos a seguir.

\subsection{Tumulto interior}

compreendo porque acredito, preservo, imito as mesmas formas da pureza recusada: nela reside a dúvida a pele que refaço. 
Laura é a protagonista de "A imitação da rosa", mulher casada que tenta retomar a rotina da normalidade após deixar um hospital psiquiátrico. Ainda com falta de jeito, as coisas são vagarosamente postas no lugar, e a mulher se prepara calmamente dentro de seu longo dia. Estabelece tarefas que não a afaste do ponto principal: o jantar que teriam na casa da amiga Carlota e que seria a esperança de elo com o passado da normalidade:

Mas agora que ela está de novo "bem", tomariam o ônibus, ela olhando como uma esposa pela janela, o braço no dele, e depois jantariam com Carlota e João, recostados na cadeira com intimidade. Há quanto tempo não via Armando enfim se recostar com intimidade e conversar com um homem? (AIDR, p. 47)

A volta ao cotidiano é cautelosamente engendrada por Laura, com listas e cumprimento de tarefas. Nas repetições sobre os afazeres do dia, a protagonista afasta de si todas as possibilidades de ócio, no entanto seu cuidado excessivo aponta sutilmente a fragilidade de cada detalhe no processo delicado para manter-se normal e tentar resgatar a vida onde tudo foi "antigamente".

A dedicação ao método e às tarefas da casa é o passo inicial para parecer de novo "bem", assim ela vai construindo um ambiente equilibrado e impessoal. Assim ela se volta para a obrigação de deixar tudo pronto para a chegada do marido, e garantirse de que está no caminho certo para manter a ordem interior. Aparentemente, tudo ao seu redor se arranjava, Laura sairia ao lado do marido para jantarem na companhia da amiga Carlota, a quem ela se dedicava com submissão aceitando sempre sua "bondade autoritária e prática", assim ela estaria "voltando a sua insignificância com reconhecimento"(AIDR, p. 48).

É de repente, no meio da arrumação da casa, que ela se depara com a própria imagem diante do espelho, suas sensações misturam-se aos traços, como se uma lente se aproximasse de seu rosto e de sua alma. A luz reflete uma mulher calma, os detalhes de sua aparência são bem comportados e a domesticidade de seus atos revelam a passividade de uma mulher moderada pelo peso de sua condição:

Laura olhou-se no espelho: e ela mesma, há quanto tempo? Seu rosto tinha uma graça doméstica, os cabelos eram presos com grampos atrás 
das orelhas grandes e pálidas. Os olhos marrons, os cabelos marrons, a pele morena e suave, tudo dava a seu rosto já não muito moço um ar modesto de mulher. Por acaso alguém veria naquela mínima ponta de surpresa que havia no fundo de seus olhos, alguém veria nesse mínimo ponto ofendido a falta dos filhos que ela nunca tivera? (AIDR, p. 48)

A imagem acima retrata também a fragilidade e insegurança de Laura diante da dificuldade de dar os primeiros passos dentro da normalidade. Enquanto Laura se observa, o tempo retroage na descrição do narrador e os traços da mulher figuram como se de uma foto antiga, de alguém que passou tempos fora de tudo. Ao ver-se revelada as reflexões são inevitáveis, então o destino que ela mantivera guardado em meio à arrumação das gavetas, ressurge às claras causando de novo um leve incômodo, e a dificuldade de caber nos moldes que assumira. llumina-se o antigo e profundo ponto da ausência de filhos, suas faltas são desnudadas pelo olhar que lança sobre si mesma.

O olhar lançado pela protagonista mistura aceitação e ausência, um ar triste e dócil, da mulher que sem filhos conforta-se no fato de possuir um marido bom e honesto. Mas ao mesmo tempo culpa-se por não haver dado filhos a esse homem, então a saída é fugir para o espaço doméstico, reassumindo seu "gosto minucioso pelo método". A dificuldade de Laura em instalar-se em casa, na rotina e novamente no papel de mulher de um homem, pode ser comparada à inquietude sempre ligada ao feminino, descrita por Simone de Beauvoir:

Leur docilité se doublé toujours d'un refus, leur refus d'une acceptation; en cela leurs attitude se rapproche de celle de la jeune fille; mais elle est plus difficile à soutenir parce qu'il ne ságit plus seulement pour la femme adulte de rêver sa vie à travers des symboles, mais de la vivre ${ }^{155}$. (BEAUVOIR, 1949, vol. II, p. 478)

Após a visada diferente sobre si mesma, Laura organiza meticulosamente a lista de seus afazeres, mas tem dificuldades em se manter na enumeração de suas listas. Seu pensamento desencadeia-se novamente em direção ao passado, ao seu

\footnotetext{
${ }^{155}$ Sua docilidade comporta sempre uma recusa, a recusa de uma aceitação; nisto sua atitude aproxima-se da atitude da moça; mas é mais difícil de sustentar porque não se trata somente para a mulher adulta de sonhar sua vida através dos símbolos e sim de vivê-la.
} 
tempo de moça "arrumada e limpa, com um gosto pela higiene pessoal e um certo horror à confusão" (AIDR, p. 48). É em comparação à amiga Carlota, que Laura ver-se diferente, sempre perdida em meio aos medos, à constante tentação da vida, escondendo-se do perigo em seu "ardor de burra".

Laura aprendeu a imitar tudo que julgava mais forte que ela, mais belo, mais seguro, é assim que relata seu medo em imitar Cristo, o que poderia ser a perdição. Com submissão parecida segue os passos do marido, preparando-se todo o dia para recebê-lo, mantendo a tranqüilidade na vida calma de ambos. Teria também que seguir os conselhos simples do médico, o copo de leite entre as refeições era tomado em respeito a Armando e aos amigos mais chegados. Cumpria tudo que ele havia the sugerido, inclusive a ser tranqüila e acreditar que ela estava bem:

Encaminhou-se para a cozinha e, como se tivesse culposamente traído com seu descuido Armando e os amigos devotados, ainda junto da geladeira bebeu os primeiros goles com um devagar ansioso, concentrando-se em cada gole com fé como se estivesse indenizando a todos e se penitenciando. (AIDR, p. 49)

Laura foge do espelho e agarra-se novamente às obrigações, como a de arrumar a casa sem deixar no espaço nada que pudesse ter a sua aparência, atitude semelhante à tomada pela protagonista juditiana, no conto anteriormente analisado. Essa característica em ambos os enredos é um recurso utilizado pelas mulheres para montar uma paisagem à revelia do eu em conflito, é preciso haver uma imagem que construa a idéia de algo impessoal, para que possa ser admirada.

No curso dos pensamentos de Laura, segue-se a tentativa de evitar a falência do cuidadoso método da execução de tarefas da casa. É através das ocupações com o espaço que ela busca se anular, perder-se na rotina tranqüila de ser "mulher de Armando". Tal anulação figura na crise que, segundo Beauvoir, instala-se no interior da mulher ao dar-se conta de que seu destino anula a liberdade de ser humano. Implicando em certa renúncia do papel de sujeito, é também o que a difere do homem, que não precisa abdicar de seus direitos para exercer sua masculinidade. Como resultado dessa constatação, muitas vezes a mulher deixa-se submeter para afirmar a soberania do outro: 
La femme elle-même reconnaît que l'univers dans son ensemble est masculin; ce sont les hommes qui l'ont façonné, régi, et qui encore aujourd'hui le dominent ; quant à elle, elle ne s'en considere pas comme responsable; il est entendu qu'elle est inférieure, dépendante (...) elle n'a jamais émergé comme un sujet en face des autres membres de la colectivité $^{156}$. (BEAUVOIR, 1949, vol. II, p. 478).

A busca da impessoalidade e o empenho da protagonista em fazer do espaço algo alheio comunga com o fato de também tratar a si mesma como alguém distante. Chegando mesmo a tratar-se em terceira pessoa, ela se afasta ao máximo da intimidade consigo mesma, fugindo da própria identidade, Laura evita encontrar-se, pois seria um caminho doloroso para aquela que se habituara a ser a mulher de um homem, sem um lugar para suas idéias ou objetivos.

Sentou-se no sofá como se fosse uma visita na sua própria casa que, tão recentemente recuperada, arrumada e fria, lembrava a tranqüilidade de uma casa alheia (...) Laura tinha tal prazer em fazer de sua casa uma coisa impessoal; de certo modo perfeita por ser impessoal. (AIDR, p. 50)

Evitar a discordância em relação aos conselhos do médico, e arrumar a casa como se não estivesse ali, eram métodos para manter-se em um lugar de neutralidade, mais seguro para quem acabara de voltar da "perfeição do planeta Marte". Todos os artifícios contribuíam para sua vontade de manter-se ao lado do marido, abandonar pra sempre a posição de "super-humana" que a acompanhara em seus dias de devaneio, podendo assim "diariamente falir", pois na sua opinião "só os iniciados compreenderiam essa nuance de vício e esse refinamento de vida" (AIDR, $p$. $51)$.

Mas a voz narrativa caminha para direção contrária ao desejo de Laura, sempre presentificando as sensações que a levaram para fora da vida agora retomada, e contrapondo a calma e o cansaço, adquiridos por ela, com os sintomas que antes a retiraram do lugar da normalidade:

\footnotetext{
${ }^{156}$ A própria mulher reconhece que o universo em seu conjunto é masculino; os homens modelaram-no, dirigiramno e ainda hoje o dominam; ela não se considera responsável; está entendido que é inferior, dependente (...) ela nunca emergiu como sujeito em face dos outros membros da coletividade.
} 
Não mais aquele ponto vazio e acordado e horrivelmente maravilhoso dentro de si. Não mais aquela terrível independência. Não mais a facilidade monstruosa e simples de não dormir (...) que na sua descrição a fizera subitamente super-humana em relação a um marido cansado e perplexo. (AIDR, p. 51)

Era preciso preservar o homem, livrá-lo do cansaço de se sentir distante da mulher que um dia ele "recebera de um pai e de um padre", ela que agora se esforçava para oferecer ao marido o tom certo da vida em família. Assegurar a ele que "ela voltara tão completamente", que não havia mais perigo, que retomava com gratidão sua rotina e "tudo se completava harmonioso" (AIDR, p. 52). No entanto era difícil a tarefa de nunca fugir da pequena rotina da casa, do cansaço dos afazeres, e estar sempre como vigia dos pensamentos, seguindo com calma seu destino de mulher doméstica.

Se fugisse do pequeno campo de acontecimentos do cotidiano, ela estaria de novo inserida na perigosa liberdade, que poderia fazê-la novamente romper com o "lugar discreto e apagado de onde, com tanto constrangimento para si e para os outros, saíra uma vez" (AIDR, p. 53). Dentre os pensamentos desencontrados, cortados por reticências e por ameaças do que a protagonista vivera, a voz narrativa mistura vontade e dever.

Há várias contradições entre o que Laura professa e as sensações denunciadas pelo narrador. A personagem tenta mexer-se com intimidade dentro da própria rotina, mas o que vemos é uma verdadeira dificuldade em cumprir os paços da vida comum, as repetições dos afazeres e as infindas listas são a prova de que Laura não está de fato inserida na normalidade. Continua super-humana, apenas tentando esconder tal fato na necessidade de voltar a ser mulher de Armando, de viver novamente na simplicidade do que se repete:

Mas, como ela ia dizendo, de braço dado, baixinha e ele alto e magro, mas ele tinha saúde, graças a Deus, e ela castanha. Ela castanha como obscuramente achava que uma esposa devia ser. Ter cabelos pretos ou louros era um excesso que, na sua vontade de acertar, ela nunca ambicionara. (AIDR, p. 56) 
Toda a "segurança" criada por Laura se quebra quando no meio da sala bem arrumada e impessoal como um lugar de espera, ela se depara com as rosas, belas e sob a luz "elas estavam em toda a sua completa e tranqüila beleza", eram flores radiantes. O súbito encontro com o buquê a deixa em choque, perdida como diante do infinito, com os olhos presos a imagem totalmente fora de suas regras. $O$ narrador descreve a perturbação de Laura como se traduzindo todo seu estado de alma, confundindo-se com a personagem a voz que narra relata o embaraço da mulher:

Olhou-as com atenção. Mas a atenção não podia se manter muito tempo como simples atenção, transformava-se logo em suave prazer, e ela não conseguia mais analisar as rosas, era obrigada a interromper-se com a mesma exclamação de curiosidade submissa: como são lindas! (AIDR, p. 57)

Mesmo perturbada diante das flores, Laura ainda ensaia uma fuga, talvez mandar as rosas de presente para Carlota, inventa vários motivos para presentear a amiga. Mas não há mais como fugir, ela já havia se perdido na sedução da imagem, e estava exposta ao perigo de não ter "controle", uma ameaça para a tranqüilidade que vinha minuciosamente construindo. Não podia fixar-se nas rosas, abismar-se demais, isso a aproximaria do estado de ausência do qual saíra ainda recente, e a colocaria novamente longe do marido e de sua realidade. É o medo de estar de novo em isolamento que a faz lutar contra a invasão das rosas em si mesma:

Era preciso tomar cuidado com o olhar de espanto dos outros. Era preciso nunca mais dar motivo para espanto, ainda mais com tudo ainda tão recente. E sobretudo poupar a todos o mínimo sofrimento da dúvida. (AIDR, p. 60)

De "mãos atadas", como a protagonista de Maria Judite, Laura abandona o falso equilíbrio e fica com o perigo das rosas diante de si. Abre mão da vida que ela tão bem vinha encaminhando para não se perder de novo no "planeta Marte". Lembrase então dos conselhos do médico, reforçando que evitasse o perigo, mas já emaranhada naquela beleza desmedida, Laura abandona-se de novo sem tarefas, listas ou coisas a arrumar, de novo distante e "super-humana". O marido a encontra 
com um rosto iluminado e o olhar é o "último pedido de perdão que já vinha misturado à altivez de uma solidão já quase perfeita" (AIDR, p. 68).

Era tarde, a mulher havia partido "alerta" no trem para longe, distante da simplicidade de sair de mãos dadas com o marido, das coisas a arrumar, Laura de novo havia abandonado tudo aquilo que precisava dela e do que ela precisava para manter-se a salvo: a regrada e tranqüila vida de ser mulher de um homem. Seu estado, "ausente" da vida doméstica, é sua maior transgressão, pela qual ela tenta pedir perdão ao homem, pois não podia simplesmente acompanhá-lo no jantar ou na vida comum que ele sempre a oferecera: "Ela estava sentada com seu vestidinho de casa. Ele sabia que ela fizera o possível para não se tornar luminosa e inalcançável. Com timidez e respeito ele a olhava" (AIDR, p. 69).

Os dois enredos trazem protagonistas que estão muito próximas em sua maneira de trafegar no cotidiano, e que, mesmo se dedicando às obrigações domésticas, não conseguem esconder a necessidade de fugir de si mesmas, e da realidade a que estão sujeitas. Elas criam diferentes estratégias, sempre ligadas ao espaço doméstico, para evitar o estado de reflexão e transgressão do qual estão tentando escapar.

Os recursos buscados para fugir de si mesmas têm como tema sempre o espaço da casa, não havendo em nenhum dos contos momentos em que as personagens rompam o espaço da casa. Tal espaço torna-se muito significativo, enquanto representação do estado submisso em que as personagens se encontram. Segundo Roberto DaMatta "não se pode misturar o espaço da rua com o da casa sem criar alguma forma de grave confusão ou até mesmo conflito" (DaMatta, 1997, p. 50). E como ambas estão tentando resolver a própria confusão que se lhes apresenta, confinam-se na "proteção" do espaço doméstico.

A casa é o espaço de proteção sendo preterido em oposição à rua que é lugar de desnorte, assim a ordem perseguida pelas duas mulheres é algo atingido através do espaço sereno do lar e da repetição das tarefas cotidianas. Ao analisar a casa segundo cada tipo social, DaMatta afirma ser esta para a mulher o "cativeiro", lugar 
onde todas "as contradições devem ser banidas sob pena de causarem um intolerável mal-estar" (DaMatta, 1997, p. 55).

É dentro de um espaço limitador, que se transforma em aquário para a personagem juditiana, e em trem para Laura, que as duas protagonistas tentam ordenar suas existências convulsas, para que caibam no espaço de pouca liberdade do cotidiano. Mas tal tentativa está marcada pela falência da ordem obsessiva e da busca pelo que se repete, e de repente tudo pode ruir. $\mathrm{O}$ desabar da tranqüilidade acontece nos dois enredos após o confronto com o espelho, de maneira diferente, elas se encontram com sua realidade levada a fundo, esclarecendo a condição menor de viver entre os muros da vida doméstica.

O narrador, no conto juditiano, apresenta-nos um espelho mais implacável, diante do qual todas as máscaras da personagem vão caindo até que vejamos um vazio em seu lugar. Ao confrontar-se com a própria imagem, a protagonista de "O aquário" se transforma e um sorriso "maquinal" e incontrolável instala-se em seu rosto. O olhar no espelho vai ganhando uma "estranha profundidade", como se fosse atirado ao mar, então a protagonista vai aos poucos se tornando apenas "uma imagem qualquer apagada", que se transforma em um vazio, uma parte da casa, uma paisagem que fazia parte do espaço: "Seu rosto turvou-se, perdeu de súbito a nitidez, transformou-se numa leve mancha esbranquiçada" (OA, p. 105).

Partindo desse estágio de revelações que nos são dadas pelo espelho é que entendemos a necessidade de fuga da protagonista, assim como as constantes mudanças dos móveis e da casa. Ela precisa mudar tudo sempre que se descobre como nada em meio ao espaço, como parte dele e sem alguma função de sujeito, apenas um objeto da decoração, essa é a condição da qual ela tenta constantemente fugir. É diante do espelho que vemos a protagonista mudar de sentido, como o sofá que passa de norte-sul a leste-oeste.

As trocas de móveis, em "O aquário", ou as listas de afazeres de Laura, explicam-se na necessidade de escape, ou de buscar saídas para tornar suportável o papel que as duas mulheres deveriam cumprir. A loucura é a transgressão que vem combater o trabalho cauteloso das personagens na busca do equilíbrio, desta visão vem a constatação de que a casa é seu aquário, em que está confinada entre 
pequenas paredes, sua condição é pequena e arrumada, como a casa "em arco de círculo".

No entanto a consciência do próprio estado as coloca diante de uma realidade insuportável, e o único caminho é recusá-la, transgredi-la, criando um mundo onde seja possível esquecer-se de si, à espera de um trem que transporte para outro "espaço", ou apenas rir-se de si mesma em seu aquário pessoal.

O espelho apresentado pelo narrador claricieano é mais descritivo, mas não menos cruel, pois é um pequeno acaso que leva Laura a parar diante do mesmo e confrontar-se com suas angústias de mulher super-humana. A revelação dos medos da protagonista, sua relação com a casa, sua "graça doméstica", assim como no enredo juditiano, estão ligadas ao espaço interno e à solidão de descobrir-se parte desse espaço.

O espelho é revelador para Laura, já que é através dele que a protagonista se reencontra com um "mínimo ponto ofendido" dentro de seus olhos, a falta de filhos. Esse "ponto" aparece também como um caminho de possibilidades para entrar em seu eu, o perigo que destruiria sua "tranqüilidade" arquitetada com excessivo gosto pelo detalhe e a arrumação de seu mundo. Mas nada pode ocultar-se ao espelho, e de repente vemos a fragilidade da imagem que vínhamos criando da protagonista, que também é traída pelo espelho e não consegue continuar "obedecendo de olhos fechados".

As etapas de descrição da personagem seguem uma ordem que nos possibilita unir as pontas para explicar seu estado de alerta, conhecemos seu horror a confusão e de onde isso vem: do medo de não mais conseguir dar conta do caos interior. Laura, assim como a protagonista de "O aquário", precisa criar caminhos circulares para não se perder em si mesma e ser traída pela desordem interior. As rápidas reflexões, sempre cortadas pelos afazeres, leva-a ao encontro de si mesma, e é também nesses momentos que o narrador descreve detalhes que compõem sua personalidade, seja no passado da época da escola, em que ela "copiava com letra perfeita os pontos da aula sem compreendê-los". Ou no presente em que ela "com seu gosto pelo método, agora reassumido, planejava arrumar a casa" (AIDR, p. 48). 
No conto clariceano há uma imagem diferente, para além do espelho que confronta a personagem: as rosas. Após o espelho, Laura tenta retomar suas listas e tarefas, continuar no "lugar discreto e apagado", onde não é permitido sentir demais. No entanto ela se depara com a excessiva beleza das rosas e isso acordará sua capacidade de sentir desmedidamente.

A imagem das rosas em sua perfeição será o caminho para se abandonar de novo naquela realidade inventada, distante de sua vida com o marido, ausente, como alguém que "já partira". Então Laura se lança outra vez para fora da normalidade, transgride o pequeno mundo no qual sairia de vestido marrom e bege para jantar com Armando, e volta ao seu estado de alerta.

O ponto de iluminação que reaparece em ambas as protagonistas será a marca da transgressão, recusar-se a uma realidade estabelecida no dever e na submissão é também ser transgressora e fugitiva. Assim elas são mulheres que saem de si por se negarem à pequena condição a que são submetidas, sendo assim vistas como anormais. É interessante observar que em nenhum dos dois enredos vemos a palavra loucura, no entanto nos é permitido conhecer o íntimo universo de duas mulheres que, saídas de um hospital psiquiátrico, convivem com a ameaça do confinamento e com a dor de sentirem-se "diferentes", e jamais conseguirem atingir a "normalidade" exigida pela sociedade.

Segundo nos explica Phillys Chesler, o asilo é o lugar-prisão, uma maneira de isolar da sociedade a mulher dita louca, mas a loucura em questão é muitas vezes traduzida no desejo de seguir um destino que não é aquele reservado por sua condição. Por isso durante muito tempo as mulheres, em sua maioria casadas, exatamente normais eram aprisionadas em hospitais psiquiátricos, a essa causa seguia-se a de possuírem o desejo de serem livres.

A manifestação de desejos era inadmissível para alguém que deveria exercer papel em prol da família e do bem estar do outro. Então a mulher que apresentasse comportamento "diferente" da docilidade e delicadeza para qual era feita, seria louca, criatura isolada: "une telle folie est essenctiellement l'experience intense de la 
castration biologique, sexuelle et culturelle de la femme, et une recherche condamnée de la puissance"157 (CHESLER, 1975, p. 45).

As duas protagonistas transitam cuidadosamente na realidade a sua volta, ensaiam uma normalidade entre parênteses, construída pelo medo de perceber-se diferente. Os atos e as palavras são frágeis e ameaçam se partirem a qualquer momento, pois elas são quase que vigiadas pelo bom senso dos maridos, figuras "equilibradas" que espreitam o desespero das mulheres. Mesmo havendo uma forte proximidade entre os conflitos que envolvem as duas protagonistas, os atalhos tomados por cada uma são diferentes.

Se observarmos a trama em "O aquário", vemos uma protagonista que de certa forma é prisioneira de si mesma, condicionada à arrumação dos móveis e á disposição desses pela casa. Ela compõe as peças do próprio labirinto, é alguém vitimada pela rotina dos dias nos quais acorda para "repetir" as ações do dia anterior, assim a protagonista constrói um retrato da incompreensão vivida por ela na sociedade. Estes detalhes formam o mosaico do devaneio que aos poucos ganha espaço dentro dela, até se tornar maior que o seu silêncio.

A necessidade do grito é representada pelo delírio de um riso que ela não consegue conter, mesmo sabendo que está de novo sucumbindo ao perigo da anormalidade e quebrando o pacto de "felicidade" reforçado todos os dias pela pergunta do marido: "Riu-se, riu-se por ali fora". (AO, p.107). A entrega ao riso é antecedida pelo fluxo de consciência ${ }^{158}$ em que toda a fragilidade de seu mundo real é posta à prova, o resultado é a negação da felicidade diariamente repetida para o marido.

Com esse ato incontido ela se rende novamente ao perigo da loucura, rompe com a realidade para suportar a angústia de sua condição. O rompimento tira a mulher do seu campo de normalidade e de seu lugar social e a leva a ser vista como louca. Para Hélène Cixous, a loucura no mundo feminino é atribuída à necessidade de expansão, de romper com os muros que limitam sentimentos e ações:

\footnotetext{
${ }^{157}$ Uma tal loucura é essencialmente a experiência da castração biológica, sexual e cultural da mulher, e uma busca condenada do poder.

${ }^{158}$ Nos referimos à ficção de fluxo de consciência conceituada por Humphrey, como "exploração dos níveis de consciência que antecedem a fala com finalidade de revelar, antes de mais nada, o estado psíquico dos personagens" (HUMPHREY, 1976, p. 4)
} 
La femme-trop: trop désirente, trop intelligente, trop active, trop malhereuse, trop heureuse, trop angoissée, trop vivante; alors trop bruyante, trop encombrante. Celle qui en crie trop long, en hurlement ou en silence, sur la femme. ${ }^{159}$ (CIXOUS, 1975, p. 7)

Romper o próprio silêncio é a rendição ao mundo dos loucos, sem obrigação com a realidade, podendo transgredir seu mundo e criar para si uma infinidade de mundos possíveis. Pensamos que esse grito lança a personagem juditiana para dentro de si mesma, o que a faz sentir-se como o peixe, sempre em círculos em torno de si e do pequeno aquário. Este é o mesmo movimento executado por ela em torno da casa, a sala em formato de círculo, os dias se passando entre os muros de sua condição, tudo faz com que aos poucos vá se produzindo dentro dela a impossibilidade de conviver com esse mundo: "e isso agitou a superfície tranqüila e rasgou a imagem em farrapos que ondularam à sua volta". (OA, p. 107).

No mundo de Laura encontraremos vários detalhes que se assemelharão aos ocorridos com a protagonista de Maria Judite. A angústia da reflexão sobre si mesma também será um peso que tornará a realidade insuportável, a condição se torna uma prisão e a saída é negá-la, mas como fazer isso e ser aceita no mundo da normalidade? A "doença" da personagem de Lispector é tratada com sutileza pelo narrador, e a época vivida no asilo também é descrita com cuidado, pois tudo faz parte de um "passado" que está sempre a ameaçar o presente: "ela super-humana e tranqüila no seu isolamento brilhante, e ele quando tímido vinha visitá-la (...) ele fazendo visita de cerimônia como um namorado, com o hálito infeliz e um sorriso fixo, esforçando-se no seu heroísmo por compreender" (AIDR, p. 52).

Durante todo o dia, Laura tenta se harmonizar com a casa, os afazeres, a espera do marido e as infinitas banalidades, forçando-se a ser de novo "humana e perecível" como todos à sua volta. A entrega a casa e a ocupação com o trabalho doméstico também estão presentes no cotidiano da protagonista de "O aquário", como Laura, ela busca se "normalizar" através do espaço a sua volta, mas é justamente nele

\footnotetext{
${ }^{159} \mathrm{~A}$ mulher demasiada : que deseja muito, muito inteligente, muito ativa, muito infeliz, muito feliz, muito angustiada, muito viva, por isso muito barulhentas e muito pesadas. Aquelas que choram muito, alto ou em silêncio, a mulher.
} 
que ela se perderá. Da mesma forma a personagem clariceana não conseguirá salvarse por muito tempo nas imensas listas de afazeres banais.

A relação com o outro é de desconfiança e incompreensão, ambas se sentem isoladas em meio ao mundo em que vivem, onde são constantemente olhadas como "estranhas", como se falassem outra língua, fossem de outro mundo. O narrador confessa que Laura saiu do planeta Marte, onde as pessoas têm o direito de serem diferentes. Podemos dar a mesma origem à personagem juditiana.

O sentimento de exílio do mundo real, assim como o medo de constranger o marido e as pessoas ao redor, são repartidos pelas duas mulheres, embora seja descrito com mais intensidade no enredo clariceano, em que as frustrações da protagonista são confrontadas por ela com certa resignação, mas sem menos angústia: "no cansaço havia um lugar bom para ela, o lugar discreto e apagado de onde com tanto constrangimento para si e para os outros, saíra uma vez (...) graças a Deus voltara" (AIDR, p. 53).

A tentativa de parecer normal, de enumerar tarefas para confirmar essa normalidade, é constante no discurso de Laura, mesmo que isso não apague a ameaça de perigo presente no fundo das frases. Este perigo se constrói com mais força a cada passo do dia, o que apontamos como mais uma distinção entre as duas mulheres, pois para a personagem juditiana, a quebra se dá logo nas primeiras linhas do conto, com a estátua que se parte e a ansiedade da protagonista em criar seus círculos.

Já no cotidiano de Laura essa quebra acontecerá somente no momento das rosas, ainda que ela tente ao máximo defender-se "disso", acaba se entregando ao estado transgressor de "super-humana". Rende-se às rosas como a personagem de Maria Judite rende-se ao aquário, entregar-se ao devaneio e livrar-se do peso do cotidiano opressor será o destino dessas mulheres. $E$ ao se negarem a viver a condição do "mundo real", só lhes caberá o lugar na loucura, que pode ser vista como uma das mais dolorosas transgressões do feminino. 


\section{3. Contando a personagem: a voz do narrador}

O diálogo é a conversa perfeita, porque tudo que uma pessoa diz recebe sua cor definida (...) a mesma pessoa tem dez maneiras de exprimir sua alma, conforme escreva a este ou àquele indivíduo.

Friedrich Nietzsche

Uma vez relatados os enredos e discutidas as passagens que sustentam as análises e a argumentação temática, passamos a uma questão marcante no que diz respeito à construção das personagens nos contos acima estudados. O narrador e a construção da voz narrativa tanto no universo juditiano como no de Lispector são ferramentas que trabalham para dizer a personagem em toda a sua intensidade.

Levando em consideração a ordem dos enredos acima apresentados, vamos seguir o caminho dos narradores das duas autoras, que certamente terão muitas divergências, porém haverá vários pontos em que se encontrarão na tentativa de "escutar" a insistente voz que chama atenção para a importância do conflito interior das personagens.

A maneira de narrar, que encontramos nas narrativas das duas ficcionistas, é aquela que, segundo Tacca, teve grande recorrência na literatura novecentista. $O$ narrador, a par de tudo que se passa com as personagens, é omnisciente como um deus, pode prever sensações, pensamentos, ou ainda colocar possíveis discursos na boca da personagem. A voz narradora imagina as reações da personagem como se fossem as suas, mostrando controle das informações e acesso a todos os espaços da história. Como nos explica o crítico espanhol:

Os plenos poderes do narrador omnisciente permitiam-lhe um livre trânsito entre o visível e o invisível. Todos os dados the eram lícitos, independentemente da sua procedência: informação, confidência, descoberta, suposição (TACCA, 1983, p. 70).

No universo das duas escritoras, a voz que narra tem a autonomia de dar a palavra ao autor e de também fazer valer a palavra da personagem. $O$ narrador juditiano trabalha ocupando-se muitas vezes da fusão entre a voz denunciadora da 
autora e a voz melancólica da personagem, como Adelaide, ou ainda a voz conformada, como no exemplo de Alma. É também com a fusão de dois ou mais discursos que trabalha o narrador clariceano, quando redimensiona um simples cotidiano para nas entrelinhas fazer ver um feminino condicionado, como é o caso de Laura, ou mesmo de Ana.

A voz narrativa contribuirá também para a estruturação do fundo históricosocial do feminino, que está presente em todos os enredos acima analisados. Através do retrato das personagens, seja em suas casas ou nas ruas, do que falam a seus maridos ou do que escutam deles, há nas várias mediações do narrador a difusão do ponto de vista das autoras sobre uma inquietude partilhada não só por Clarice e Maria Judite, mas por tantas outras escritoras: a condição da mulher de sua época.

A falta de lugar no mundo, fora da casa ou do casamento, a preocupação em parecer feliz ou conformada com a vida que levam, e assim poder agradar o marido, são sentimentos que conhecemos através da transmissão de um narrador que está com a personagem, muitas vezes se misturando com esta a tal ponto que temos dificuldade em identificá-lo. Como no exemplo abaixo retirado de "O aquário":

Recusavam-se a compreender. Tinham talvez receio, quem sabe? Olhavam-na de lado. Para compreender era preciso... E os outros, os eu não eram essas pessoas podiam pensar...e no entanto era tão simples, pois não era? (OA, p. 106)

A cumplicidade existente entre narrador e personagem permite que aquele exerça ao mesmo tempo a função de descrever o estado de conflito em que esta se encontra e ainda colocar o leitor como participante de tal conflito. Mesmo sem ter acompanhado a história da personagem antes do pequeno espaço da casa, o leitor a conhece pela voz narradora, para justificar que se trata de alguém que se sentiu sempre em estado de exílio e incompreensão no meio em que vive. São vozes que aliadas anunciam uma precariedade do mundo no qual essas mulheres vivem, daí a necessidade de evasão. ${ }^{160}$

\footnotetext{
${ }^{160} \mathrm{O}$ que é na descrição de Oscar Tacca uma característica do mundo do romance: "Mundo cheio de vozes, sem que uma só seja real, sem que a única voz real do romance revele uma origem” (TACCA; 1983, p.61)
} 
Há em "Amor" a força da voz de um narrador que se confunde com a da personagem e que nos traduz suas reflexões, seus medos ou inclinações, a voz se modifica a cada passo que dá para dentro da vida da protagonista, e vai exercendo vários tons à medida que cresce a tensão da narrativa. Tal voz é que nos coloca logo no início do conto diante da protagonista no momento de sua subida no bonde, para em seguida nos conduzir ao interior da casa nos fazendo conhecer "o calmo horizonte" que a cerca.

As oscilações da voz do narrador estão associadas ao tempo, pois colocam o leitor no presente da tarde de Ana, para em seguida levá-lo para o passado da frágil estrutura familiar construída por ela. As enunciações que ora são presságios, ora denúncias permitem seguir a personagem no caminho do choque que logo se dará. $O$ discurso é construído para ir revelando pouco a pouco os fios do tecido que encobre a realidade da protagonista, até o momento que por "caminhos tortos viera a cair num destino de mulher" (A, p.30).

Dentro da descrição da casa, dos objetos, alguns feitos pelas mãos da mulher, há um olhar atento do narrador para os vestígios do ambiente que denotam a tentativa de equilíbrio, e de curar-se da "doença de vida" que sempre ameaçara Ana, mas que no presente do relato a deixara descansar na verdade de seu marido e dos filhos e nos "calmos deveres" adormecendo as inquietudes do passado.

A função do narrador é importante também para nos fazer conhecer a trajetória da protagonista, é assim que sabemos que as inquietudes e conflitos já marcavam a vida de Ana mesmo antes de ser a mulher que construíra um lar ameno. As analepses e as prolepses são recorrentes no discurso do narrador, como recursos que nos permitem desenhar o quadro do comportamento da protagonista. Descrevendo as sensações e os medos de Ana como se falasse de dentro de sua consciência, e insinuando o fim do estado de calma, é assim que o narrador demonstra conhecimento para além daquele da protagonista.

O narrador, não representado, apresenta-nos toda a matéria da narrativa, jogando luz sobre a protagonista e através dela nos fazendo conhecer os demais personagens, deixando tudo se passar na terceira pessoa, em uma focalização 
interna ${ }^{161}$. Este é também o caminho por onde passa o narrador de Maria Judite, ao descrever a vida sem cor de Alma. É a voz do narrador que nos põe a par dos sonhos da mulher e que determinará a perspectiva da imagem sonhada por ela. Aproximando os dois contos, vemos que o narrador constrói a enunciação de maneira que nos deixe conhecer a insatisfação e os conflitos que tanto Alma quanto Ana tentam esconder.

Conhecemos a personalidade das protagonistas mais pelo que nos mostra o narrador do que por elas mesmas. Podemos dizer que a missão da voz narrativa é nos dar as peças para que conheçamos o meio em que vivem essas mulheres e como se constitui a insatisfação e a angústia que as acompanha. Por isso o tempo do narrado é também o de um encontro, de Ana com o cego, e de Alma com o espelho. Buscas diferentes, mas que se aproximam através das circunstâncias descritas pela voz narradora.

Nos enredos de "Amor" e "A estranha ressonância do nome de Alma", o modo de narrar ganha mais importância do que o fato narrado, e as personagens carregam em si a relevância desviada dos acontecimentos. As duas mulheres estão em confronto com o próprio eu e em oposição ao mundo, é o que descobrimos através das informações que nos vêm do narrador. Portanto, além de se manter como sujeito da enunciação, o narrador também ocupa a função de alguém que relata e comenta detalhes desconhecidos até mesmo pelas personagens: "A mulher, que se chamava alma, não sabia, mas tinha lido coisas, nos jornais. E era útil. Não sabia a que mas era útil." (AERNA, p. 23).

Ou que denuncia uma fragilidade também disfarçada pelo cotidiano doméstico:

Todo o seu desejo vagamente artístico encaminhara-se há muito no sentido de tornar os dias realizados e belos; com o tempo, seu gosto pelo decorativo se desenvolvera e suplantara a íntima desordem. (A, p. 30)

"Amor" é um conto que se encontra dentro do estilo de narrativa clariceana, apresentando muitas das características da temática comum às obras da autora, segundo a observação de Benedito Nunes:

\footnotetext{
${ }^{161}$ Optamos pelo termo de Genette da focalização interna, baseando-se também na denominação de visão com de J. Pouillon, in GENETTE, Gerard. Discours du récit: essai de méthode. Paris : Seuil, 2007, p. 194 e 195.
} 
a inquietação, o desejo de ser, o predomínio da consciência reflexiva, a violência interiorizada nas relações humanas, a potência mágica do olhar, a exteriorização da existência, a desagregação do eu, a identidade simulada, o impulso ao dizer expressivo, o grotesco e/ou escatológico, a náusea e o descotínio silencioso das coisas. ${ }^{162}$

Para nos dar um panorama da vida que a protagonista construíra, mostrar que tudo vinha de uma tentativa de sobrepor conflitos interiores e ainda deixar ver que a ameaça de romper com a aparente tranqüilidade era constante, o narrador assume a posição com a personagem. Ele então a acompanha em suas tarefas domésticas, na calma das perigosas horas em que não há nada mais a executar. Somente essa posição de focalizar a personagem por dentro, e de estar com ela em toda a trajetória narrativa, poderia nos informar que logo chegaria "o fim da hora instável".

As demais personagens são descritas segundo a visada calma que Ana lança sobre o cotidiano: os filhos bons e crescendo como deviam, um marido que chega sempre na hora devida, apenas o necessário é revelado nesse jogo de mostrar e esconder, o narrador constrói a suspeita e a expectativa para o momento do choque. No entanto é na protagonista que o narrador se ampara, tanto na ficção de Clarice como nos enredos de Maria Judite, para exercer sua função ele perscruta o interior das personagens, e então transmite ao leitor o conflito que nelas se passa e que gera a tensão narrativa. É justamente o tom e a execução do discurso ${ }^{163}$ da voz que narra que nos dará à medida de tal tensão, denunciando as verdades interiores das duas mulheres.

A maneira com que cada contexto é apresentado, no entanto, diferencia-se. Nos dois enredos temos uma voz forte que une passado e presente construindo um tecido narrativo todo baseado nos estágios pelos quais passam as personagens. São narradores em terceira pessoa, porém com total autoridade para descrever e analisar a personagem, É através da voz narrativa que somos informados da dimensão do conflito das duas protagonistas, assim como de suas falências na tentativa de manter o equilíbrio e de agarrar-se ao que pode salvar do estranhamento, Alma tenta achar-se em sua tensa relação com o marido:

\footnotetext{
${ }^{162}$ NUNES, Benedito. O drama da linguagem. São Paulo: Ática, 1995, p. 100.

${ }^{163}$ Segundo Oscar Tacca, cabe ao narrador a tradução das personagens, é a ênfase dada por ele a determinadas informações sobre a personagem que nos coloca diante do conflito interior das mesmas. (TACCA, 1983, p. 66)
} 
O silêncio desceu de novo entre ambos, alastrou pela casa onde não havia mais ninguém, tornou tudo estático. Um silêncio pesado que ela às vezes sentia vontade de afastar de si como quem afasta a roupa da cama em noites quentes. Um pouco como se sufocasse.(AERNA, p. 22)

Enquanto Ana volta para casa na esperança de retomar a vida como antes e recuperar o eu perdido:

Abriu a porta de casa. A sala era grande, quadrada, as maçanetas brilhavam limpas, os vidros da janela brilhavam, a lâmpada brilhava que nova terra era essa? E por um instante a vida sadia que levava até agora pareceu-lhe um modo moralmente louco de viver. (A, p. 37)

O narrador projeta as personagens sob o signo do olhar, seja aquele míope do rosto no espelho, ou o que se amplia na experiência do dia a dia. Mesmo com semelhanças quanto ao narrador e quanto à voz que executa o discurso narrativo, há inúmeras diferenças entre o narrador clariceano e o narrador de Maria Judite. Segundo Benedito Nunes, o núcleo da narrativa em Clarice Lispector concentra-se geralmente em um momento de tensão onde encontramos todo o cerne do conflito narrado.

Em algumas narrativas "a tensão conflitiva se declara subitamente e estabelece uma ruptura do personagem com o mundo" (NUNES, 1995, p. 84), porém o clímax se apazigua, e o mundo antes em pedaços vai tomando forma outra vez, ainda que sem apagar os vestígios de tensão que existiam no começo. Ana vive seu momento de ruptura durante o tempo que passa no Jardim Botânico, mudam coisas e pessoas diante dela, mudam os sentimentos e intensificam-se as reflexões, mas a lembrança dos filhos a faz romper com a fuga e retomar o cotidiano.

A vida de todos os dias, a calma que ela tão trabalhosamente construíra acaba vencendo a revolução que por momentos ela vivera, e a narrativa assume novamente a harmonia com o mundo e o cotidiano das coisas que se repetem. A circularidade do enredo é representada na diminuição da intensidade das coisas que, agora modificadas, tentam novamente se harmonizar dentro do cotidiano. $\mathrm{O}$ vento forte $\mathrm{e}$ perigoso que balançava as cortinas da casa resume-se ao pequeno sopro dado por Ana para apagar a enorme chama do dia: 
E, se atravessara o amor e seu inferno, penteava-se agora diante do espelho, por um instante sem nenhum mundo do coração. Antes de se deitar, como se apagasse uma vela, soprou a pequena flama do dia. (A, p. 41)

No conto juditiano, a voz narrativa trabalha também na circularidade do tempo, e a personagem continua diante do espelho, avançando apenas na suposição de ter um novo rosto. O narrador, a ultrapassa e zomba de sua ingenuidade, como tem as informações sobre tudo que se passara entre o cirurgião e o marido, deixa que Alma pense ser loucura o que bem poderia se tornar realidade: "Foi ao quarto, viu-se ao espelho. Que coisa estúpida lhe passara de repente pela cabeça! A de que aquele homem poderia... Não é verdade? Que loucura a sua" (AERNA, p. 29).

Parecido ao que acontece no universo clariceano, o narrador de Maria Judite por estar com a personagem, pode traduzir seus anseios, mas como tem o domínio também de todos os eventos narrados, relata as frustrações e esperanças perdidas por Alma com uma espécie de nudez que chega a atingir a crueldade. Como sujeito da enunciação, ele utiliza a própria fala da personagem também para transmitir seu discurso intencional, como nos explica Benilde Caniato a cerca do discurso narrativo em Maria Judite:

No plano da focalização, narrador e personagem, próximos e identificados, assumem o discurso de forma uníssona, projetando-se nas formas lingüísticas, com traços espontâneos e afetivos da fala da personagem, e objetivos do narrador. (CANIATO, 1996, p. 73)

A situação narrativa que envolve Adelaide e a protagonista de "O búfalo" acontece em um viés parecido aos analisados acima. No primeiro caso há a rápida retroação no tempo para sabermos que se trata de uma mulher com necessidade de sonhar para suportar a vida sem amor com um marido distante. A voz narrativa descreve a situação de constrangimento de Adelaide diante do homem com quem tinha a intenção de fugir, e o desprezo com que este a recebera com a mala cheia de ilusão: 
Vê-la-ia, ouvi-la-ia ainda durante algum tempo, especada naquele limiar de porta, magrinha e oscilante, como que vergada ao peso dos longos cabelos, ou da mala, ou da dor. Nessa altura ainda ela não tremia nem chorava nem sentia medo. Tudo isso viria depois, misturado com um claro desejo de morrer, e um obscuro medo de procurar a morte. (A, $p$. 83)

A antecipação das sensações, dos sentimentos e desejos que viriam em seguida, faz com que o leitor observe o domínio do narrador sobre a história de malogro de Adelaide. É também a informação que é fornecida acima que nos certifica de que no momento final do conto Adelaide não morrerá em meio aos carros da movimentada avenida na qual segue envergada pelo peso da decepção.

Em "O búfalo" há uma forte tensão desde a cena inicial, o narrador omite mais do que informa, e por isso o leitor não tem a informação de que se trata de uma mulher abandonada ou não. A trama é sutil e o que podemos acompanhar é que a personagem está buscando nos olhos dos bichos força para converter seu amor em ódio:

"Eu te odeio", disse ela para um homem cujo crime único era o de não amá-la. "Eu te odeio", disse muito apressada. Mas não sabia sequer como se fazia. Como cavar na terra até encontrar a água negra, como abrir passagem na terra dura e chegar jamais a si mesma? (OB; 159)

As formas lingüísticas do discurso apontam para a condição de desnorteada da mulher, as interrogações mostram o retrato de um conflito interior que se alastra de dentro para fora, expressando-se em seus olhos tentando retirar os bichos da primavera onde não há lugar para o ódio. Após acompanhar a personagem em um súbito vôo na montanha russa, a voz narradora lança também o leitor no centro do conflito da mulher, na intimidade de seu perdão, para denunciar a docilidade submissa parecida á que também obrigara Adelaide a fugir. Levado pelas mãos do narrador, o leitor participa do eu dividido e do choque das duas mulheres, em suas buscas infindas:

Onde aprender a odiar para não morrer de amor? $\mathrm{E}$ com quem? O mundo de primavera, o mundo das bestas que na primavera se 
cristalizam em patas que arranham mas não dói... (...) se aquela mulher perdoasse mais uma vez, uma só vez que fosse, sua vida estaria perdida (OB, p. 163)

Temos um narrador que através do discurso indireto livre vê pelos olhos da personagem, julga através de sua consciência, e fala quase como se fosse a própria personagem. O narrador em "O búfalo", assim como em “Adelaide”, reúne informações de maneira omnisciente ${ }^{164}$ em relação às personagens. É a voz que conta e que às vezes mistura-se a das personagens que nos permitirá pintar o quadro de suas vidas, condição e malogros.

Numa retroação no tempo e na vida de Adelaide, o narrador juditiano nos leva a conhecer a ingenuidade da personagem, e de como era presa fácil de uma ilusão, e até mesmo que vivia a querer iludir-se, para combater a realidade. É a voz narrativa que fornece as informações para sabermos que a mulher procurava no homem a salvação que sempre buscara nos outros e tudo tinha sido tão ao acaso e ao mesmo tempo tão necessário a ela, que quase o isentamos de culpa:

Ela, porém, não sabia. Fazia uma vida muito retirada e o marido fora buscá-la à província. Não conhecia, pois, esses jogos elegantes. A mãe era tão burguesa que ignorava que o era, que ignorava mesmo o que era ser burguesa. (A, p. 86)

O narrador altera a disposição cronológica da história, e através de uma analepse expõe a situação na qual Adelaide vivia, e assim sabemos que fora trazida de uma pequena cidade pelo homem com quem casara, como uma aquisição. Informanos também da necessidade de se fazer vítima do outro para vingar-se da indiferença do marido. De novo é a voz narrativa que nos põe a par dos fatos do passado para nos esclarecer o presente.

Ela olhava para ele como quem não compreendia. Mas já tinha esse olhar quinze dias antes, naquela reunião onde a conhecera melhor porque houvera uma cadeira vaga ao seu lado e ele se sentia fatigado

\footnotetext{
${ }^{164}$ Oscar Tacca classifica o as informações do narrador como "equisciente", quando o narrador possui o mesmo conhecimento que o das personagens, e "omnisciente" quando esse conhecimento ultrapassa o das personagens. (TACCA, 1983, p. 68).
} 
para estar em pé. Tinha nessa noite um olhar de rapariguinha atrasada. (A, p. 85)

Os ritos de iniciação e de passagem na vida das personagens de "Preciosidade" e "Um diário para saudade" são intensificados pela voz narradora, que acompanha as personagens. No primeiro enredo, o narrador descreve a personagem já chamando atenção para sua particularidade escondida na sombra de sua timidez: "E dentro da nebulosidade algo precioso. Que não se espreguiçava, não se comprometia, não se contaminava. Que era intenso como uma jóia. Ela" (P, p. 103).

As informações do narrador nos aproximam do universo da adolescente, indicando que ela possui certa sensibilidade que entra em choque com o mundo ao seu redor. Tais dados se tornarão peças importantes para entendermos o conflito da personagem, a ameaça dos dezesseis anos que chegava, a afronta de passar diante dos operários no ônibus, ou dos meninos no corredor da escola, formam o quadro de um cotidiano difícil de enfrentar:

Mas também de rapazes tinha medo, medo também de meninos. Medo que the "dissessem alguma coisa", que a olhassem muito. Na gravidade da boca fechada havia a grande súplica: respeitassem-na. (P, p. 104)

A voz da personagem articulada em discurso direto se mistura com aquela do narrador em discurso indireto e aproxima ainda mais as sensações da adolescente, revelando os perigos que podiam quebrar sua estrutura. $\mathrm{O}$ caminho feito pelo narrador nos faz ver a personagem de vários ângulos, podemos então descobrir que o rosto sério de todas as manhãs servia para esconder que "por dentro o coração batia de medo" (P, p. 105).

As contradições que surgem da caracterização da frágil menina e da força que Ihe vem para vencer o mundo a cada manhã são dados que fazem com que ela nos escape a uma apreensão total, o que é, nas palavras de Antônio Candido, uma "descontinuidade" do ser percebido por outro ser, no presente caso, a personagem percebida pelo narrador. Não podemos apreender a personagem por inteiro, pois "sua natureza é oculta à exploração de qualquer sentido e não pode, em conseqüência, ser 
apreendida numa integridade que essencialmente não possui”. (CANDIDO, 2000, p. 56).

O narrador, que nos faz conhecer a menina solitária de "Um diário para saudade", é representado por uma voz que analisa e descreve e também antecipa ao leitor que a morte virá prematuramente à menina Saudade:

O pai era um homem definitivo e sem remissão. Para ele não havia dúvidas, nem problemas insolúveis. A mãe fora cheia deles e encontrara na fuga a única solução para se libertar de uma caixa fechada, às vezes quase asfixiante. Isso, claro, não o sabia Saudade, não tinha idade para tanto, nunca, de resto, a teria. (UDPS, p. 96)

No trecho acima, a voz narrativa demonstra total autonomia sobre o destino da personagem, ao julgar e analisar uma situação, ao descrever sensação alheia à própria personagem, e ainda ao antecipar um acontecimento que culminará no desfecho do enredo. A descrição do narrador aponta para a reclusão e o temor das relações sociais que faziam da menina alvo dos outros colegas, a "falta de confiança com que encarava tudo e todos" (UDPS, p. 96). Sua fragilidade é a de alguém que fora abandonada, não pela vida ou pelo marido como ocorre com as protagonistas juditianas, mas pela mãe, mulher sonhadora que partira em busca de uma paixão.

O narrador abre um parêntese no tempo da menina de nove anos e volta a alguns anos antes, para o dia da fuga da mãe. A voz narrativa compara e ajuíza a personalidade da mulher que fugira com a da madrasta, esta "era digna e honesta", enquanto a fugitiva "era a desorganização e o caos", se tornando assunto proibido pelo pai, não se falava mais o nome da mãe, portanto a Saudade só resta escrever tudo que sente. $\mathrm{O}$ estado de solidão da menina é analisado pelo narrador que se mistura ao pensamento da personagem, ajuizando suas reflexões:

Era a ausente, senhora portanto de todas as perfeições. Se a mãe tivesse ficado...Não gostaria dela? Não gostava, decerto, visto que a tinha trocado e ao pai por um homem qualquer, com quem se fora sabese lá para onde (...) Mas se a mãe não gostara dela (pensava sempre no passado), quem gostaria? (UDPS, p. 94) 
$\mathrm{O}$ trecho aproxima o discurso indireto e o indireto livre para transmitir as reflexões, dúvidas e conflitos que se acumulavam no interior de Saudade. As perguntas feitas pelo narrador não se dirigem à personagem, de quem ele conhece todas as respostas; nem à autora, de quem ele media o pensamento, então resta o leitor para tentar responder tais perguntas. Os questionamentos feitos pelo narrador são dirigidos ao leitor quando a voz narradora nos leva a pensar sobre aquele fato ou momento da narrativa, e de como se tornou importante na construção da personalidade da menina. Por isso tal procedimento pode ser visto, no universo das duas autoras, como um recurso para chamar atenção à importância do conflito ou de tal reflexão da personagem.

Os momentos finais do conto são os de maior tensão, pois Saudade tem seu diário descoberto pelos colegas e entregue nas mãos da professora. Há momentos em que a cena é protagonizada pela voz narradora, a menina permanece estática e em silêncio e o narrador toma-lhe a palavra e os gestos:

Não leve o livro, implorava em silêncio, não o abra, não o leia, por favor. É meu, é tudo que tenho. Se o ler é como se...como se...A mestra saiu, porém, de rompante, e houve uma algazarra que Saudade não ouviu totalmente porque ainda continuava a ser, de certo modo, estátua. (UDPS, p. 98)

Como resultado do choque, a protagonista fica paralisada, sem voz e sem gestos, então é o narrador que toma o controle da situação, analisa o desespero de Saudade diante da possibilidade de ter suas confissões descobertas por todos. Sem ver e sem ouvir nada, tudo que fala ou pensa é obra da omnisciência do narrador. A menina só abandonará seu estado de estátua para se lançar em fuga, que tem como destino a morte, o que também é narrado pela consciência e análise da voz narradora: "Como um autocarro ia nesse momento a descer, Saudade foi colhida, até porque se lançou, por assim dizer, contra ele". (UDPS, p. 99).

Ao aproximarmos "Os laços de família" e "Carta aberta à família" nos deparamos com funções narradoras que se diferem no que diz respeito à posição em relação às personagens. A primeira narrativa tem um narrador que mostra conhecimento sobre os fatos, mas tem sempre o cuidado de reforçar a verdade 
narrativa com a fala das personagens. Sua primeira grande investida se refere ao momento em que mãe e filha são lançadas uma contra a outra no táxi, o choque é analisado pela voz que narra a impressão das duas mulheres:

Catarina olhava a mãe, e a mãe olhava a filha, e também a Catarina acontecera um desastre? Seus olhos piscaram surpreendidos (...) Porque de fato sucedera alguma coisa, seria inútil esconder: Catarina fora lançada contra Severina, numa intimidade de corpo há muito esquecida, vinda do tempo em que se tem pai e mãe. Apesar de que nunca se haviam realmente abraçado ou beijado. (OLF, p. 119)

Essa é uma das poucas investidas do narrador em que o mesmo assume o julgamento e análise da situação sem dar a palavra às personagens. Mas logo em seguida, o constrangimento é reforçado através da junção de discurso direto e indireto, misturando-se á voz narrativa:

Mas depois do choque no táxi e depois de se ajeitarem, não tinham o que falar - por que não chegavam logo à estação?

- Não esqueci de nada? perguntou a mãe com voz resignada.

Catarina não queria mais fitá-la nem responder-lhe.

- Tome suas luvas! disse-lhe, recolhendo-as do chão. (OLF, p. 120)

A insistência da mãe sobre ter esquecido algo na casa da filha é questionada e refletida para levar também o leitor a se perguntar o que de fato havia sido esquecido, e se ainda era possível recuperar. Tal questionamento vai se respondendo nas vozes de narrador e personagens, possibilitando assim a compreensão sobre a crise de afeto que existe entre mãe e filha:

- ...Não esqueci de nada? Perguntou a mãe. Também a Catarina parecia que haviam esquecido de alguma coisa, e ambas se olhavam atônitas porque se realmente haviam esquecido, agora era tarde demais (...) novamente a campainha da estação soou...Mamãe, disse a mulher. Que coisa tinham esquecido de dizer uma a outra, e agora era tarde demais. (OLF, p. 121)

O confronto de olhares é disfarçado, mãe e filha escondem-se atrás de recomendações banais, esquecendo os laços que nunca construíram e que agora faltavam a uma e a outra. O narrador acompanha a volta de Catarina pra casa, 
descreve o redimensionamento das ruas pelos olhos da mulher, que agora anda em um outro "caminho aberto pela sua mãe que the ardia no peito".

O conflito mal resolvido com a mãe se prolonga com o filho e o marido, o menino segue indiferente e nervoso, "comunicando-se consigo mesmo". O marido é alguém que dera a Catarina um apartamento bem arrumado e a chance de casar-se com um homem de carreira. As informações do narrador levam a constatar que o conflito dos laços de afeto com os pais é transmitido para o presente da mulher. A impossibilidade da fala é substituída pelo gesto, a Catarina pega o filho pela mão e sai sem explicar nada ao marido. O narrador serve-se dos olhos do marido para descrever as duas figuras na rua, que pareciam como estranhos para o homem:

O marido repetiu-se a pergunta que, mesmo sob sua inocência de frase cotidiana, inquietou-o: aonde vão? Via preocupado que sua mulher guiava a criança e temia que nesse momento em que ambos estavam fora de seu alcance ela transmitisse a seu filho... mas o que? "Catarina", pensou, "Catarina, esta criança ainda é inocente!" (OLDF, p. 125)

As reticências e interrogações são modalizadores do discurso do narrador para descrever a crise do marido ao ver que havia perdido o controle sobre sua mulher e seu filho. O narrador projeta os pensamentos do homem, o recurso para fugir de um presente sem controle seria pensar que logo "este dia se quebraria com as ondas nos rochedos do Arpoador". (OLF, p.127)

A voz narrativa em "Carta aberta à família" utiliza o recurso do discurso da personagem para reforçar o narrado, como o narrador clariceano, no entanto o enredo juditiano sobrepõe variações narrativas e discursos, espécie de mosaico que vai da confissão às imagens, tudo contribuindo para reforçar aquilo que é narrado. Há várias vozes que se intercalam com a do narrador em terceira pessoa e com posição equisciente em relação à protagonista, configurando um jogo no qual autor e leitor têm seu papel:

Ao leitor compete aceitar e configurar o jogo, seguindo a voz que o orienta. Deste modo, o efeito lúdico e evasivo do jogo, é simultaneamente vivido pelo autor que escreveu e projectou a entrada da voz narrativa e vivido pelo leitor que experimenta configurar uma história 
possível ou impossível, a partir das sugestões que lhes são dadas pela voz do texto. (NAVAS, 2004, p. 52)

Três são as formas de narrativa que se intercalam: a voz do narrador, que transmite o estado de angústia da mulher durante um domingo com o filho; a carta, uma espécie de confissão feita pela protagonista e possivelmente endereçada ao filho e ao marido, de quem se separara anos antes. Mas o conteúdo da suposta carta não apresenta de fato um destinatário, e se configura mais como uma confissão, ou um relato de memória. Há também a narrativa de um filme que a mulher assiste com o filho no cinema, o enredo do filme dialoga diretamente com a história dela. Assim o narrador constrói uma teia narrativa que sobrepõe pontos de vista e prende a atenção e a observação do leitor:

Mary era loira, tinha grandes olhos azuis e estava apaixonada. O pai contrariava-lhe, porém, a inclinação, porque tinha em vistas 0 proprietário de um rancho. A rapariga, porém, lutou, e, como não podia deixar de ser, vencer. Eu não lutei porque não tinha porque lutar, não valia a pena. Só mais tarde foi que o problema surgiu, estava casada havia cinco anos. (...) Mary corria a cavalo pelos campos. (CAF, p. 126)

No trecho intercalam-se a carta-confissão da protagonista com as cenas do filme, no entanto o enredo do filme é contado na voz do narrador, é ele que seleciona os recortes do filme de acordo com o relato da mulher. Oscar Tacca defende que o romance epistolar é o que mais pode favorecer o autor-transcritor, isto é, o autor assume o papel de relator de um fato no qual a voz é totalmente dada à personagem, assim o texto pode confundir-se com a confissão de um diário íntimo.

Quando as várias instâncias narrativas se juntam, como no trecho acima, inscreve-se uma história dentro da outra, construindo o que Tacca classifica como incrustação ${ }^{165}$, estrutura em que as imagens são postas dentro do texto, fazendo com que se encontrem no conjunto destinador-mensagem-destinatário. É também um recurso em que se pode-se juntar várias vozes sem que nenhuma sobreponha a outra, e em que todas reforcem a verdade narrativa.

\footnotetext{
${ }^{165}$ Para Oscar Tacca, a denominação se aplica quando uma outra história é inserida dentro da principal, ou ainda outros tipos de textos ou imagens, com o intuito de reforçar a idéia principal $(1983$, p. 55).
} 
Em "O aquário" os vários recursos e as vozes trabalham para reforçar o narrado, a protagonista expõe seus sentimentos, as causas de sua fuga com um outro homem, o desejo de morte, tudo the vem como uma imagem que aos poucos vai se tornando nítida diante de seus olhos. As lembranças vão se dispondo no mesmo momento em que a mulher passa o último domingo do mês com o filho, como era o hábito. Os diálogos com o menino se cruzam com as páginas de sua carta:

Depois fora a sala escura do cinema. Eugénio se inclinara para ela e perguntara baixinho:

"Acha que o rapaz e a rapariga se casam?"

"Acho que sim. O rapaz e a rapariga, quando gostam um do outro, casam-se sempre e são muito felizes"

"Acha que o homem rico..."

"Ora, o homem rico perde a partida, vais ver"

Eugênio endireitara-se tranqüilizado.

Casei-me mas não gostava do meu marido, nem dele nem de ninguém, valha a verdade. (CAF, p. 125)

O diálogo da mulher com o filho, em discurso direto, é transcrito entre aspas, como se escutado pelo narrador e transmitido ao leitor. Os trechos da carta aparecem sempre em itálico, dando a impressão de serem citados, e o narrador é o mediador das várias vozes que surgem na narrativa. A protagonista assume o relato de seu passado, a separação, a falta de amor pelo marido, e de como foi conduzida ao casamento com o homem de família importante.

O relato confessional, em tom de um diário, limita a visão do leitor ao que diz a mulher sobre suas angústias e dificuldade a conviver no mundo do marido. Por outro lado observamos os questionamentos do narrador que fazem juízo da consciência da personagem, avaliam seu ato de fuga, levando a crer que os feitos do passado não podem ser revogados, nem diante do filho ou do marido ela pode se justificar:

Agora subiam a avenida e ela gostaria uma vez mais de saber o que pensava o filho do facto de ela ter um dia abandonado tudo, de o ter abandonado mesmo a ele. Que lhe teriam dito? E de que maneira? Gostaria de se defender, de lhe apresentar as circunstâncias atenuantes do seu acto, mas sentia que tudo o que dissesse seria improfícuo. Valeria então a pena fazê-lo? (CAF, p. 128) 
Como em um tribunal, temos uma voz narradora que acusa, mas que também é a mesma que defende, dando lugar à confissão da mulher, sendo ainda a voz mediadora do diálogo entre a mãe e o filho e de como as limitações criadas pelo passado impediam o afeto entre ambos. Caberia para este narrador juditiano, as palavras de Ligia Chiappini:

Quem nos fala é esse eu. Os canais que utiliza são os mais variados, predominando a sua própria observação direta. Finalmente, somos colocados a uma DISTÂNCIA, ao mesmo tempo menor, do narrado - já que temos acesso até aos pensamentos das personagens -, e maior, porque a presença do narrador medeia sempre, ostensiva, entre nós e os fatos narrados. ${ }^{166}$

O narrador espreita o cotidiano das protagonistas em "O aquário" e "A imitação da rosa", com o olhar vigilante, põe à prova a reabilitação de duas mulheres que tentam misturar-se ao cotidiano da vida simples para esconderem sua "luminosidade". O conto juditiano é conduzido por uma voz narradora em terceira pessoa, com um conhecimento equisciente dos fatos, e que descreve os movimentos da personagem dentro do espaço da casa. Logo se observa que os detalhes na descrição colaboram para a construção do estado em que se encontra a personagem.

A obsessiva ordenação dos móveis e a criação de círculos dentro da sala, valorizam o espaço, que se torna a via por onde a personagem externa sua crise interior. Então o caminho do conflito parte do eu para o espaço, o incômodo que sente consigo mesma é disfarçado na modificação constante da posição dos objetos. Estas informações nos vêm da voz narradora que, posicionada na consciência da personagem, faz as ligações entre a desordem interior e a ordenação do espaço:

A escrivaninha dificultava a entrada. Não era a única dificuldade. Que importância podia ter mais uma? Dificuldade em acordar (...) dificuldade em repetir pela milésima vez que sim, que era feliz - em dias excepcionais achava-se mesmo na obrigação de dizer que era muito feliz (OA, p. 104 - grifo do autor)

\footnotetext{
${ }^{166}$ LEITE, Ligia Chiappini Moraes. O foco narrativo (ou a polêmica em torno da ilusão). 10. ed. São Paulo: Ática, 2000, p. 29, grifos do autor.
} 
Suas reflexões se transformam em representação espacial, como se pintasse um quadro daquilo que figura em sua consciência, assim ela materializa seu conflito. As informações do narrador tendem a se dilatar e nos fazer cada vez mais entrar no espaço interior da personagem, e conseqüentemente descobrimos que sua tarefa obsessiva visa substituir a confusão interior que construiu ao longo de seu cotidiano, pela perspectiva visual, aquela que tem da casa, e que precisa ser constantemente modificada.

Temos então um narrador que está com a personagem e que, como ressaltado acima, nos descreve sua consciência, os conflitos que carrega e que tenta amenizar com a falsa afirmação de que é feliz. O tempo, assim como o espaço, decorre de maneira subjetiva, e o narrador faz algumas analepses para informar sobre hábitos de fuga com os quais a protagonista acostumara-se a disfarçar as próprias crises de se ver prisioneira de uma realidade da qual não fazia parte:

Estava sozinha, de bilhete na mão, a olhar para si própria dentro da montra de água onde se exibia para seu próprio regalo. Regalo? Era um espetáculo fascinante a que ela fugia sempre que possível. Qualquer pretexto era bom. Precipitava-se sobre o livro que começara a ler e não tinha sido capaz de continuar. la pegar outra vez na camisola de malha que abandonara logo ao princípio. (OA, p. 105)

A classificação que melhor se aproxima do narrador juditiano em "O aquário" é aquela denominada por Gérard Genette (1972, p. 195) como focalização zero, que coloca o ponto de vista do narrador em uma amplitude de poderes, sua visão é ilimitada, permitindo acompanhar passos, pensamentos e atos das personagens. Um dos momentos em que se determina clara a posição da voz narrativa é quando a protagonista estagna-se diante do espelho, então o narrador descreve a imagem como se a personagem fosse parte de um grande aquário:

O espelho quadrado lançou-lhe em rosto o sorriso de agora, que the surgiu maquinalmente na boca. O fim da tarde dava uma estranha profundidade às coisas e ela era simplesmente uma coisa, uma imagem qualquer apagada, a boiar na escura transparência das águas tristes e solitárias do seu aquário pessoal. (OA, p.105) 
O narrador volta ao passado da personagem para informar que as fugas sempre foram necessárias, e que continuariam a ser, pois ela se sentia incompreendida naquele mundo onde as pessoas "Falavam outra linguagem". Em um discurso indireto livre o narrador descreve toda a reflexão convulsa da protagonista: "Olhavam-na de lado. Para compreender era preciso... e os outros, os que não eram essas pessoas, podiam pensar... e no entanto era tão simples, pois não era?" (OA, p.106). O discurso é marcado por modalizadores (era preciso..., e no entanto) que indicam a subjetividade da voz narradora, assim como o estado de angústia em que se encontra a personagem.

As imagens se transformam, a protagonista torna-se prisioneira da casa arrumada com a mobília em "arco de círculo", o espaço passa a ser o grande aquário. O narrador descreve a transformação da personagem, que sai do estado de ação, de interventora do espaço, para ocupar "seu exíguo metro cúbico de água turva" (OA, p. 107), misturada aos objetos da casa e paralisada como se fosse parte de uma pintura.

Em "A imitação da rosa" temos um narrador que também acompanha todos os movimentos da personagem durante sua rotina de um dia. Descrevendo a consciência da personagem, a voz narradora supõe a normalização da vida de Laura. Sua recuperação do estado luminoso que a levara ao asilo estabelece-se no detalhe, e o narrador a segue também nesses detalhes, tendo um conhecimento equisciente. Para fazer ouvir a personagem utiliza o discurso direto livre:

As pessoas felizmente ajudavam a fazê-la sentir que agora estava "bem". Sem a fitarem, ajudavam-na ativamente a esquecer, fingindo elas próprias o esquecimento como se tivessem lido a mesma bula do mesmo vidro de remédio. Ou tinham esquecido realmente, quem sabe. Há quanto tempo não via Armando enfim se recostar com abandono, esquecido dela? E ela mesma? (AIDR, p. 48)

A verdade se constrói pelo engano, o discurso irônico do narrador destrói a falsa normalidade da vida de Laura, a contribuição dos outros segue orientações como as de um medicamento, e são de fato a negação de seu restabelecimento. A expressão "há quanto tempo" e as interrogações feitas pelo narrador são as marcas do discurso que indicam a subjetividade e a dúvida. 
O narrador por vezes escapa à sua própria posição, pois ao mesmo tempo que se aproxima e até associa-se à personagem, em sua tentativa de se mostrar bem, sentindo-lhe os medos e restrições, ele também afasta-se, ironiza e faz seu próprio juízo do verdadeiro estado da protagonista. Através de analepses são apresentados momentos do passado de Laura que contribuem para a explicação de seu estado atual:

Quando Ihe haviam dado para ler "A imitação de Cristo", com um ardor de burra ela lera sem entender mas, que Deus a perdoasse, ela sentia que quem imitasse Cristo estaria perdido - perdido na luz, mas perigosamente perdido. Cristo era a pior tentação. (AIDR, p. 49)

O cotidiano é narrado como ponto de apoio da personagem, o narrador acompanha as repetições de tarefas e listas que Laura começa, mas abandona sempre que se perde em sua divagação. Tais divagações são enunciadas pelo narrador como se pequenas recaídas na recuperação tão afirmada, porém tão fragilmente construída:

Há quanto tempo não se cansava? Mas agora sentia-se todos os dias quase exausta e passara, por exemplo, as camisas de Armando, sempre gostara de passar a ferro e, sem modéstia, era uma passadeira de mão cheia. E depois ficava exausta como uma recompensa. Não mais aquela falta alerta de fadiga. Não mais aquele ponto vazio e acordado e horrivelmente maravilhoso dentro de si. (AIDR, p. 51)

A voz narrativa aproxima de maneira analítica as reações da personagem em relação ao já vivido há muito tempo e o presente, deixando ver o risco que ainda existe para ela ao se aproximar da realidade. As tarefas figuram como uma real ligação com o mundo simples das coisas que se repetem, porém Laura continua a conviver com as ameaças de quebra e retorno ao lugar de exílio. A interrogação usada pelo narrador chama atenção para a angústia do período de incertezas vivido pela personagem.

As informações manejadas pelo narrador o aproximam ainda mais da personagem, e o discurso indireto livre é o dado lingüístico de confirmação de tal proximidade. As repetições sobre cansar-se novamente, ou sobre tudo que teria de fazer antes que o marido voltasse, são constantes, como se Laura tivesse 
desenvolvendo um aprendizado. A voz narrativa a acompanha em todas as etapas deste exercício de reaprender a viver sua vida:

Sempre invejara as pessoas que diziam "não tive tempo" e agora ela era de novo uma pessoa tão ocupada: iam jantar com Carlota e tudo tinha que estar ordeiramente pronto, era o primeiro jantar fora desde que voltara e ela não queria chegar atrasada, tinha que estar pronta quando... bem, eu já disse isso mil vezes, pensou encabulada. (AIDR, p. 54)

O discurso do narrador é construído como se tivesse por objetivo negar os pensamentos da personagem ou alertar o leitor da fragilidade do ambiente de aparências criado, ou imaginado, por ela. Até quando transcreve o pensamento da personagem diretamente, o narrador o faz como se fosse o seu próprio, a ausência de travessão ou outro sinal que indique que é Laura quem pensa diretamente comprovam a total união entre a voz narradora e a consciência da personagem.

Um dos traços marcantes nas tramas vividas pelas personagens acima, é que se configuram através da mediação forte de um narrador que não economiza recursos para fazer ver o conflito das personagens, sobretudo diante da escolha entre destino e liberdade. Conseqüentemente, surgem outros conflitos como a fragilidade das relações, e a dificuldade de afeto quando se quebram os papéis sociais. Tudo isso mostrado pela ótica das personagens, como afirma Benilde J. Caniato, sobre a voz narradora em Maria Judite:

Optando por ver o mundo com os olhos de suas personagens, por contar aquilo em que elas acreditam, a adesão e/ou a identificação, sempre marcadas pelo isolamento, permitem ao porta-voz tornar-se a consciência narradora do narrado. (CANIATO, 2006, p. 87 - grifos do autor).

$\mathrm{Na}$ escritura das duas ficcionistas os seres importam mais do que os fatos, suas personagens apresentam intensa vida interior, juntamente com um conflito que tende a crescer no decorrer do enredo. No plano estrutural, as protagonistas podem ser classificadas como redondas ou esféricas, muitas vezes surpreendendo o leitor 
com as revelações de seus conflitos, vacilações ou obsessões (Adelaide, que parte com malas para fugir com um desconhecido; ou a protagonista de "O búfalo" buscando o ódio entre os bichos).

Tanto em "A imitação da rosa" e "O aquário" como nos demais exemplos acima citados, vemos um traço comum na voz que narra: a importância em detalhar a personagem, no caso das narrativas aqui estudadas as protagonistas femininas. A voz que narra também se encarrega de retratar a diegese ${ }^{167}$ dos enredos sempre em relação às personagens. Os acontecimentos relevantes, quando existem, são apenas pretextos, ou atalhos tomados para chegar ao cerne, ao alvo principal da função do narrador de Clarice ou de Maria Judite, que é contar a personagem.

\footnotetext{
${ }^{167}$ Segundo Genette é o universo espacio-temporal no qual se desenvolve a história, o mundo possível do enredo e que nos faz compreendê-lo. (1972, p. 62).
} 


\section{Conclusão}

quem atinge um alto nível de abstração está em fronteira com a loucura (...) é preciso antes saber, depois esquecer. Só então se começa a respirar livremente.

Clarice Lispector

Ela grita com fraca voz que ainda tem, gritará até poder, a sua dupla condição de pobre e de velha. Mas, se ignorância não houvesse, decerto por sabedoria.

Maria Judite de Carvalho

Uma das tentativas de nosso trabalho foi a de revelar que na construção das personagens de Clarice e Mara Judite há a forte presença dos problemas sociais que sempre inquietaram o feminino. Na voz, no grito ou no silêncio, que presenciamos nos vários enredos, ficou marcado o protesto além da tentativa de ultrapassar limites, escapando da submissão.

Também observamos que a circularidade e o inacabado são marcantes para as duas autoras. O que comprovamos principalmente através de situações que se alongam sem buscar resoluções, ou ainda conflitos que se repetem no decorrer da vida das personagens e que contribuem para a dificuldade de concluir ou acabar de dizer algo sobre as mesmas.

São autoras escorregadias e donas de uma liberdade forte e sensível, suas obras têm palavras apontadas, como as setas despedidas, para a tradução de um sentimento e de uma condição que se esconde sob todas as aparências sociais. Sobre a autora portuguesa definiu acertadamente Benilde J. Caniato:

A contribuição de Maria Judite de Carvalho às letras portuguesas traduzse, principalmente, pelas verdades interiores de suas figuras femininas, que passam a ganhar presença no estreito mundo de suas solidões. Não explodem de ansiedade nem procuram enganar-se de ilusões, ainda que a elas só lhes caiba conscientemente um subalterno papel de representatividade no mundo dos homens. (1996, p. 85)

As palavras acima também poderiam ser ditas a respeito da escritura de Clarice, principalmente no que diz respeito às "verdades interiores" das personagens femininas e de como essas ganham voz e tornam-se cada vez mais lúcidas a respeito do papel que ocupam no mundo. Porém as mulheres que percorrem as narrativas clariceanas mascaram a subalternidade nos momentos de choque em que se deixam 
levar pelo impulso que as move a romper com a condição. Mesmo permanecendo ou voltando ao papel de representatividade, o que se quebra dentro delas cria por vezes um poder capaz de burlar a submissão das personagens.

Há desde o projeto literário de Maria Judite e de Clarice, como nos descreve Benedito Nunes, uma "inquietação sempre renovada da personagem", numa trajetória onde o objetivo não é chegar, mas continuar a seguir rumo à "peregrinação do desejo insatisfeito, convertido num movimento de errância, numa intérmina busca. Intérmina também é a narrativa que fica suspensa à insatisfatória busca interior" ${ }^{168}$ das personagens.

$\mathrm{Na}$ trajetória das personagens das duas escritoras, os momentos em que saem de si, levadas pela necessidade de romper com a realidade, reforçam o duplo com que sempre conviveu o feminino, e que é representado principalmente na separação entre destino e liberdade. Explicando-se na argumentação de Beauvoir, já antes citada, através da qual o destino de mulher anularia a condição de ser humano, daí chegarmos ao fato de que a personagem tem que romper com a condição para existir como sujeito.

No entanto tal rompimento, tanto na escrita clariceana como na de Maria Judite, traduz-se como um ensaio, a tentativa de um vôo. A principal conseqüência deste ensaio é que a ruptura das personagens traduz-se em uma espécie de transgressão assistida, como se percorressem apenas o caminho que não as tirasse do campo de visão do outro. Seria a fuga de Catarina, observada pelo marido através da janela; ou a partida de Laura, que permanece no sofá a espera do trem. A volta sem rumo de Adelaide, cansada pelo peso da mala e da angústia; ou a confissão aberta da personagem que, não conseguindo ser uma Cercal, não suportou o não lugar de uma vida solitária.

Nosso estudo nos possibilitou ver que a mulher dividida e o conflito entre consciência e dever a cumprir foram sempre matéria da escrita dessas duas autoras, que tanto contribuíram para renovar a discussão do papel feminino, denunciando o lado alienante da submissão. Na escrita para jornais, tantos anos praticada por Clarice e Maria Judite, também se evidenciaram tais conflitos, entre conselhos de

\footnotetext{
${ }^{168}$ NUNES, Benedito. "Destroços da introspecção", in ZIBERMAN, Regina; VIEIRA, Nelson; NUNES, Benedito. A narração do indizível. Porto Alegre: Artes e Ofícios, 1998, p. 36.
} 
comportamento, dicas de beleza, havia sempre a preocupação em despertar suas leitoras para o olhar sobre si mesma. Como nos explica Maria Aparecida Nunes:

Nos contos de Clarice, a fuga da realidade permite momentos de epifania. Mas as duas mulheres - a leitora para a qual a coluna se destina e a personagem clariceana - sentem-se sufocadas pelos afazeres domésticos, pelo destino de mulher (...) Clarice privilegia os instantes em que essa mulher deixa de ter funções domésticas domesticadas para encontrar-se a si mesma em uma outra realidade incontrolável, que não a da casa, dos filhos, do marido ${ }^{169}$.

Talvez fosse impossível romper totalmente com a condição e seus papéis, mas não era impossível vencer o medo e a acomodação que faziam a mulher permanecer em posição desfavorecida. Por isso foram importantes também as colaborações juditianas para os jornais de sua época, segundo Ruth Navas havia "uma relação imediata e directa entre o texto escrito pela autora e a realidade vivida das mulheres dos anos cinquenta e sessenta" (NAVAS, 2004, p. 11). Para Maria Judite, assim como para Clarice, a escrita era uma arma de intervenção social, que Ihes permitia dar voz às minorias silenciadas.

O universo das duas escritoras nos possibilita ver a escrita como resistência à submissão e auxílio na busca de uma posição social mais ativa. Suas narrativas, como vimos, são marcadas também pela presença da consciência objetiva que assumem frente à sua condição e ao papel social para elas determinado. Encontramos nas personagens, ainda que de maneira sutil, sinais de tal posicionamento ${ }^{170}$, característica já apontada por Caniato ao referir-se a obra da escritora portuguesa:

Assim nos parece que as Graças, as Marianas, as Joanas, dispersadas, em pedaços, revigoram-se em sua solidão para enfrentar as falências às quais estão condenadas irremediavelmente. (CANIATO, 1996, p. 23)

O valor maior das narrativas das autoras brasileira e portuguesa não está no meio ou no objeto pelo qual a vida se desnuda. No geral são situações comuns, dias

\footnotetext{
${ }^{169}$ NUNES, Aparecida Maria. Clarice Lispector jornalista: páginas femininas \& outras páginas. São Paulo: Editora Senac, 2006, p. 157.

${ }^{170}$ A respeito do papel social na obra de Maria Judite de Carvalho ver NAVAS, Ruth. Leituras hipertextuais das crônicas de Maria Judite de Carvalho. Lisboa: Edições Colibri, 2004.
} 
de chuva ou de primavera, espelhos ou estátuas, ruas movimentadas ou jardins desertos. O mais importante é como as coisas mudam de dimensão e como tudo se torna visível numa sociedade onde os deveres superam direitos. As personagens se segregam em casamentos que mais oprimem que acolhem, as relações em sua volta por vezes são vistas de maneira profunda e por isso assustadora. Estes são, como vimos, alguns dos vestígios que aproximam essas duas escritoras, e que se traduzem nas palavras de Benilde:

Ainda que se mostre muito sensível, a mulher-escritora assume atitudes objetivas bem realistas, em face de sua própria condição e comportamento. As análises de suas figuras femininas apresentam-se detidas e profundas, traduzindo-se em verdades interiores, que procuram expressar o sentido da existência. (CANIATO, 1996, p. 16)

Os vários contos, crônicas, novelas e romances das autoras podem nos mostrar fiéis retratos dos conflitos do feminino da época. Principalmente quando refletem o sofrimento das personagens por não transitar bem no estreito mundo familiar, buscando na solidão uma possível (dis)solução para os conflitos interiores. Ou ainda quando buscam um meio transgressor para escapar da realidade asfixiante.

Os conflitos vividos por cada personagem ecoam como protestos contra uma submissão que não poderia mais ser aceita. Sendo também resultado de terem aprendido a enfrentar a própria condição, pois como disse Clarice "a condição não se cura mas o medo da condição é curável" (LISPECTOR, 1994, p. 119). Embora tal enfrentamento aconteça de maneira diferente no universo de cada escritora, vemos que as personagens de uma e de outra assumem o papel de exiladas, postas para fora do sistema de regras sob as quais devem viver para serem mulheres normais.

Clarice Lispector e Maria Judite, através de suas personagens, dão voz a mulheres que se encontram na ausência, naquilo que lhes falta é que habita o ponto máximo de sua reflexão. O espelho acusa o destino de Alma na ausência de beleza e Laura busca na ausência de filhos consolar-se com o cotidiano simples.

Caminhos sem chegadas, buscas sem encontros são representados nas idas e vindas nas vidas das personagens, fazendo-nos pensar que chegamos aqui com a sensação de nada haver de pronto, de concluído. Porém sabemos que, a proposta de 
reflexão, presente na obra das autoras jamais deixará o leitor impune. A aproximação dos universos de Clarice e Maria Judite nos fez observar uma liberdade infinita e perigosa, que pode iluminar ou cegar quem dela muito se aproxima, num eterno (des)encantamento. 


\section{Referências bibliográficas}

1. Títulos dos contos citados em iniciais:

1.1- De Laços de família:

- Amor (A)

- O búfalo (OB)

- Preciosidade $(P)$

- Os laços de família (OLF)

- A imitação da rosa (AIDR)

1.2- De Flores ao telefone

- A estranha ressonância do nome de Alma (AERNA)

- Adelaide (A)

- Carta aberta à família (CAF)

- Um diário para Saudade (UDPS)

- $O$ aquário (OA)

\section{Bibliografia de Clarice Lispector}

Perto do coração selvagem. Rio de Janeiro, A Noite, 1944.

O lustre. Rio de Janeiro, Agir, 1946.

A cidade sitiada. Rio de Janeiro, A Noite, 1946.

Alguns contos. Rio de Janeiro, Ministério da Educação e Saúde, 1952, Cadernos de Cultura.

A maçã no escuro. Rio de Janeiro, Francisco Alves, 1961.

A paixão segundo G.H. Rio de Janeiro: Editora do Autor, 1964.

Felicidade clandestina. Rio de Janeiro: Sabiá, 1971.

Água viva. Rio de Janeiro: Artenova, 1973.

A via-crucis do corpo. Rio de Janeiro, Artenova, 1974.

Onde estivestes de noite. Rio de Janeiro, Artenova, 1974.

De corpo inteiro (entrevistas). Rio de Janeiro: Artenova, 1975.

Visão do esplendor. Rio de Janeiro: Francisco Alves, 1975. 
A hora da estrela. Rio de Janeiro: José Olympio, 1977.

Um sopro de vida. Rio de Janeiro: Nova Fronteira, 1978.

Laços de família. Rio de Janeiro, Francisco Alves, 1992.

A legião estrangeira. São Paulo, Siciliano, 1992.

A descoberta do mundo. Rio de Janeiro, Francisco Alves, 1994.

Uma aprendizagem ou o livro dos prazeres. Rio de Janeiro, Francisco, 1991.

A bela e a fera. Rio de Janeiro, Rocco, 1999.

Correspondências. Org. Teresa Montero. Rio de Janeiro, Rocco, 2002.

Outros escritos. Rio de Janeiro, Rocco, 2005.

Correio feminino. Org. Aparecida Maria Nunes. Rio de Janeiro: Rocco, 2006.

Minhas queridas. Rio de janeiro: Rocco, 2007.

Só para mulheres, conselhos, receitas e segredos. Org. Aparecida Maria Nunes.

Rio de Janeiro: Rocco, 2008.

\section{Livros infantis}

O mistério do coelho pensante. Rio de Janeiro: José Álvaro, 1967.

A mulher que matou os peixes. Rio de Janeiro: Sabia, 1969.

A vida íntima de Laura. Rio de Janeiro, José Olympio, 1974.

Quase de verdade. Rio de Janeiro: Rocco, 1978.

\section{Bibliografia de Maria Judite de Carvalho}

As palavras poupadas. Lisboa, Editora Arcádia, 1961.

Paisagens sem barcos. Lisboa, Editora Arcádia, 1963.

Os armários vazios. Lisboa, Portugália, 1966.

O seu amor por Etel. Lisboa, Movimento, 1967.

Os idólatras. Lisboa, Prelo, 1969.

Flores ao telefone. Ovar, Contemporânea, 1968.

Tanta gente, Mariana. 3. ed., Lisboa: Prelo, 1971.

Tempo de Mercês. Lisboa, Seara Nova, 1973.

A janela fingida. Lisboa, Seara Nova, 1975.

O homem no arame. Lisboa, Bertrand, 1979. 
Além do quadro. Lisboa, O Jornal, 1983.

Este tempo. Lisboa: Editorial Caminho,1991.

Seta despedida. Lisboa, Publicações Europa-América, 1995.

A flor que havia na água parada. Lisboa, Publicações Europa-América, 1998.

Diários de Emília Bravo. Org. Ruth Navas. Lisboa: Caminho, 2002.

\section{A cerca da obra das autoras}

ARÊAS, Vilma. Clarice Lispector: com a ponta dos dedos. São Paulo: Companhia das Letras, 2005.

BASTOS, Batista. "Maria Judite de Carvalho: uma escritora que é bom ler". In: Ler : livros e leitores. Lisboa, edição n. 5,1989, p. 29-31.

BORELLI, Olga. Clarice Lispector: Esboço para um Possível Retrato. Rio de janeiro, Nova Fronteira, 1981.

BUESCU, Helena Carvalhão. "Somos todos homines sacri: uma leitura agambiana de Maria Judite de Carvalho". In Chiaroscuro: modernidade e literatura. Porto: Campo das Letras, 2001.

CANIATO, Benilde Justo. A solidão de mulheres a sós. São Paulo, Centro de Estudos Portugueses da Faculdade de Filosofia, Letras e Ciências Humanas da USP, 1996.

CARROZZA, Elza Wagner. "Masculino/feminino - o eterno contraponto: uma leitura dos contos de Maria Judite de Carvalho e Lygia Fagundes Telles". In Cadernos da condição feminina. Actas II, nº 43. Lisboa, 1995.

CIXOUS, Hélène. L'Heure de Clarice Lispector. Precedé de vivre l'orange. Paris: Editions Des femmes, 1979.

COELHO, Jacinto Prado. "Maria Judite de Carvalho: As palavras poupadas". In Ao contrário de Penélope. Lisboa, Bertrand, 1976, p. 275-278.

COCHOFEL, João José. "Maria Judite de Carvalho: Flores ao Telefone". In Críticas e Crónicas. Temas portugueses. Lisboa: Imprensa Nacional - Casa da Moeda, 1982. 266-269.

DINIS, Nelson. A arte da fuga em Clarice Lispector. Paraná: Editora da Universidade Estadual de Londrina, 2001. 
ESTEVES, José Manuel da Costa. "Seta despedida de Maria Judite de Carvalho: uma forma abreviada sobre a dificuldade de viver". In Le conte en langue portugaise: Études de cas. Centre de Recherche sur les pays lusophones -CREPAL, cahier n. 6. Paris: Presses de la Sorbonne Nouvelle, 1999.

. Littérature portugaise contemporaine: le plaisir du partage. Paris: L'Harmattan, 2008.

GALVÃO, Walnice Nogueira e GOTLIB, Nádia B. Prezado senhor, Prezada senhora: Estudos sobre Cartas. São Paulo: Companhia das Letras, 2000.

GINZBURG, Jaime. "A literatura contra o Estado em 1968: política e exclusão em Clarice Lispector". In Revista Atlântica. Publicação da Área de Estudos Comparados de Literaturas de Língua Portuguesa, Departamento de Letras Clássicas e Vernáculas da Universidade de São Paulo, n. 12, São Paulo, 2007.

GOTLIB, Nádia Battella. Clarice: Uma vida que se conta. São Paulo, Ática, 1995. . "Leituras do feminino: Uma história de desrecalque (Virginia Woolf, Simone de Beauvoir, Clarice Lispector)". In Anais dos $1^{\circ}$ e $2^{\circ}$ Simpósios de Literatura Comparada. Belo Horizonte, Imprensa da Universidade Federal de Minas Gerais, 1987, pp. 306-310.

. "Une apprentissage des sens". In Revue Études français. Canadá: La Presse Universitire de Montréal, vol. 25, n. 1, 1989, p. 69-80.

GOTLIB, Nádia Battella. Clarice, Fotobiografia. São Paulo: Edusp, Imprensa Oficial, 2007;

IANNACE, Ricardo. A leitora Clarice Lispector. São Paulo: Edusp, 2001.

LEPECKI, Maria Lucia. "Maria Judite de Carvalho: circularidade da ação, procura da palavra". In Meridianos do texto. Lisboa: Assírio Alvim, 1979, p. 193-201.

LINS, Álvaro. "A experiência incompleta: Clarice Lispector". In Os mortos de sobrecasaca - Ensaios e estudos: 1940-1960. Rio de Janeiro, Civilização Brasileira, 1963.

LOPES, Oscar. "Maria Judite de Carvalho". In Literatura Portuguesa do século XX. Lisboa: Caminho, 1986, p. 131-135.

MANZO, Lícia. Era uma vez: Eu, a não-ficção na obra de Clarice Lispector. Curitiba: Secretaria de Estado da Cultura, 2001. 
MOSER, Benjamin. Clarice, uma biografia. Trad. José G. Couto. São Paulo: Cosac Naify, 2009.

NAVAS, Ruth. Leituras hipertextuais das crônicas de Maria Judite de Carvalho. Lisboa: Edições Colibri, 2004.

"Escrever sobre Maria Judite de Carvalho". In Revista Vértice. Lisboa: Caminho, Edição n. 32, nov. 1990, p. 112-114.

NUNES, Aparecida Maria. Clarice Lispector jornalista: Páginas femininas \& outras páginas. São Paulo: Editora Senac, 2006.

NUNES, Benedito. O Drama da Linguagem: Uma Leitura de Clarice Lispector. 2.ed. São Paulo: Ática, 1972.

. O Mundo de Clarice Lispector. Manaus: Edições do governo do estado do Amazonas, 1966.

. "Os destroços da introspecção". In Clarice Lispector: A Narração do Indizível. Porto Alegre: Artes e Ofícios, 1998.

NUNES, Benedito. Clarice Lispector. São Paulo: Edições Quiron, 1973.

NOLASCO, Edgar Cézar. Clarice Lispector: nas entrelinhas da escritura. São Paulo: AnnaBlumme Editora, 2001.

. Restos da ficção: a criação biográfico-literária de Clarice Lispector. São Paulo: AnnaBlumme Editora, 2004.

. Espectros de Clarice Lispector, uma homenagem. São Paulo: Pedro \& João editores, 2007.

PATAI, Daphne. "L'essentialisme de Clarice Lispector". In Revue Études Français, n. 25, janvier, 1989.

PONTIERI, Regina Lúcia. Clarice Lispector: uma poética do olhar. São Paulo, Ateliê Editorial, 1999.

PERRONE-MOISES, Leyla. "A fantástica verdade de Clarice". In Flores da escrivaninha. São Paulo: Companhia das Letras, 2006.

ROSENBAUM, Yudith. Metamorfoses do mal: uma leitura de Clarice Lispector. São Paulo: Edusp/Fapesp, 2006.

SÁ, Olga de. A escritura de Clarice Lispector. Petrópolis: Editora Vozes, 1993. 
SCHIMIT, Rita Terezinha (Org.). A ficção de Clarice: nas fronteiras do (im)possível. Porto Alegre: Editora Sagra Luzzatto, 2003.

SEIXO, Maria Alzira. "Maria Judite de Carvalho: um tempo de integração". In Para um estudo da expressão do tempo no romance português contemporâneo. Lisboa: Imprensa Nacional-Casa da moeda, 1987.

. "Maria Judite de Carvalho: um tempo de integração". In Para um estudo da expressão do tempo no romance português contemporâneo. $2^{\mathrm{a} e d . ; ~ L i s b o a: ~}$ Imprensa Nacional - Casa da Moeda, 1987. (1ªed., 1968)

SILVA, Rodrigues da. "Maria Judite de Carvalho, uma voz estrangulada". In Jornal de Letras, Artes e Idéias. Lisboa, 22 de maio de 1996, p. 16-17.

SOUSA, Carlos Mendes de. Clarice Lispector: figuras da escrita. Braga: Universidade do Minho, 2000.

SOUZA, Gilda de M. "O vertiginoso relance". In Exercícios de Leitura. São Paulo: Duas Cidades, 1980.

VARIN, Claire. Clarice Lispector: rencontres brésiliennes. Quebec: Éditions Trois, 1987.

\section{Obras teóricas de apoio}

ABDALA JUNIOR, Benjamin. Literatura, história e política: Literaturas de Língua Portuguesa no séc. XX. São Paulo: Ateliê Editorial, 2007.

. Incertas relações: Brasil-Portugal no século XX. São Paulo: Editora Senac, 2003.

. Tempos da literatura brasileira. São Paulo: Ática, 2004.

ABDALA JUNIOR, Benjamin. História Social da literatura portuguesa. São Paulo: Editora Ática, 1982.

AMORGHATE, Daniel et ALBISTUR, Maité. Histoire du féminisme français: de l'impire napoléonien à nous jours. Tome 2. Paris: Éditions des Femmes, 1977.

ANDRADE, Almir. As duas faces do tempo. São Paulo: José Olympio, 1971. ANDREAS-SALOMÉ, Lou. Reflexões sobre o problema do amor e 0 erotismo. Trad. Antonio Daniel Abreu. São Paulo: Landy Editora, 2005. 
BACHELARD, Gaston. A poética do espaço. Trad. Rosemary Costhek Abílio. São Paulo, Martins Fontes, 2000.

BAKHTIN, Mikhail. Marxismo e filosofia da linguagem. Trad. M. Lahud e Yara F. Vieira. Sã Paulo: Hucitec, 1979.

BARROSO, Carmen Lucia de Melo. Mulher, sociedade e estado no Brasil. São Paulo, Brasiliense-Unicef, 1982.

BARRENO, Maria Isabel. HORTA, Maria Teresa da. COSTA, Maria Velho da. Novas cartas portuguesas. Rio de Janeiro: Nórdica, 1974.

BARTHES, Roland. Le degré zero de l'écriture. Paris: Éditions du Seuil, 1972.

BATAILLE, George. "A transgressão". In 0 erotismo. Porto Alegre: L\&PM Editores, 1997.

. «Emily Brontë et la transgression». In La Littérature et le mal. Paris: Gallimard, 1957.

BEAUVOIR, Simone. Le deuxième sexe vols. I et II. Paris: Éditions Gallimard, 1949. . O existencialismo e a sabedoria das nações. Lisboa: Minotauro, 1965.

. La femme rompue: l'âge de discrétion, monologue. Paris: Éditions Gallimard, 1967.

BEAUVOIR. Simone de. La vieillesse. Paris: Gallimard, 1970.

BENJAMIN, Walter. "O narrador". In Obras escolhidas vol. 1: Magia e técnica, arte e política. São Paulo: Brasiliense, 1994.

BERGSON, Henri. Matière et memoire: essai sur la relation du corps à l'esprit. Paris: Quadrige-Presses Universitaires de France, 1985.

BLONCH-DANO, Evelyne. "Les ombres porteuses". In Elles, Histoires de femmes. Paris: Editions Filipacchi-SONODIP, 1999.

BOSI, Alfredo. "Fenomenologia do olhar". In O olhar. Org. Adauto Novaes. São Paulo: Companhia das Letras, 1998, pp. $65-93$.

BOSI, Ecléa. Memória e sociedade: lembranças de velhos. São Paulo: T. A. Queiroz, Editor, 1987.

BOURDIEU, Pierre. La domination masculine. Paris: Éditions du Seuil, 1998. BRAIT, Beth. A personagem. São Paulo: Ática, 1999. 
BRUSCHINI, Maria Cristina Aranha. Mulher, casa e família: cotidiano nas camadas médias paulistanas. São Paulo: Fundação Carlos Chagas: Vértice, Editora Revista dos Tribunais, 1990.

. "Nem heroínas nem vítimas". In Rebeldia e Submissão. São Paulo: Fundação Carlos Chagas: Vértice, Editora Revista dos Tribunais, 1989.

BUTLER, Judith. Problemas de gênero: Feminismo e subversão da identidade. Rio de Janeiro: Civilização Brasileira, 2003.

BUTOR, Michel. Repertório. São Paulo: Editora Perspectiva, 1974.

CANDIDO, Antonio. Literatura e sociedade: estudos de teoria e história literária. São Paulo: T. A Queiroz, 2000.

. "A personagem do romance". In A personagem de ficção. São Paulo, Perspectiva, 2000.

CARVALHAL, Tania Franco. Literatura Comparada. São Paulo: Ática, 2006.

CERTEAU, Michel de; GIARD, Luce; MAYOL, Pierre. A invenção do cotidiano 2: morar, cozinhar. Trad. Ephraim F. Alves e Lucia Endlich orth. Petrópolis: Vozes, 1996.

CHARTIER, Roger. "Différence entre les sexes et domination symbolique» in Histoire des femmes, histoire sociale dans Annales ESC, 48 année, n. 4, juillet-août 1993.

CHAUÍ, Marilena, "Janela da alma, espelho do mundo". In 0 olhar. Org. Adauto Novaes. São Paulo: Companhia das Letras, 1998, pp. 31- 63.

CHESLER, Phyllis. Les femmes et la folie. Trad. J.-P. Cottereau. Paris: Payot, 1975. CIDADE, Hernani. Lições de cultura luso-brasileira: Épocas e estilos na literatura e nas artes plásticas. Rio de Janeiro: Livros de Portugal, 1960.

CIXOUS, Hélène et CLÉMENT, C. La jeune née. Paris : Union Générale d'Éditions, 1975.

COELHO, Nelly Novaes. A literatura feminina no Brasil contemporâneo. São Paulo: Siciliano, 1993.

. "O discurso-em-crise na literatura feminina portuguesa". In Revista Via Atlântica, Publicação da Área de Estudos Comparados de Literaturas de Língua Portuguesa do Departamento de Letras Clássicas e Vernáculas da Universidade de São Paulo. N. 2, 1999, pp. 120 a 128. 
COLETTE, Sidonie Gabrielle. La seconde. Paris: Éditions Stock, 1984. . La Maison de Claudine. Paris: Librairie Hachette, 1960.

DAMATTA, Roberto. A casa \& a rua: espaço, cidadania, mulher e morte no Brasil. Rio de Janeiro: Rocco, 1997.

DEL PRIORE, Mary. História das mulheres no Brasil. São Paulo, Contexto-Unesp, 2004.

DIDIER, Béatrice. L'écriture-femme. Paris, Presses Universitaires de France, 1999. .Le journal intime. Paris: Presses Universitaires de France, 1976.

ENGEL, Magali. "Psiquiatria e feminilidade". In História das mulheres no Brasil. Org. Mary Del Priore. São Paulo, Contexto-Unesp, 2004.

. "As fronteiras da anormalidade: psiquiatria e controle social". In História, Ciências, Saúde - Manguinhos, v. 3; nov. 1998-fev. 1999, pp. 547-563.

ERNAUX, Annie. Les armoires vides. Paris: Gallimard, 1974.

. La place. Collection Folio, Paris: Éditions Gallimard, 1983.

FERREIRA, Dina Maria Martins. Discurso feminino e identidade social. São Paulo: Annablume, 2002.

FERREIRA, Luzilá Gonçalves (Org.). A escrita da nova mulher. Recife: PósGraduação em Letras/UFPE, 2005.

FREUD, Sigmund. "Sexualidade feminina" e "Feminilidade". In Edição Standart das Obras Psicológicas Completas de Sigmund Freud vols. XXI e XXII. Rio de Janeiro: Imago, 1974 e 1976.

FOUCAULT, Michel. "A mulher". In História da sexualidade: o cuidado de si, vol. III. Trad. Maria Thereza Albuquerque. 3. ed. Rio de Janeiro, Graal, 1985.

GARCIA, Irma. "La femme dans l'écriture ». In Promenade femmilière: recherche sur l'ecriture feminine. Paris: Editions Des Femmes, 1981.

GENETTE, Gerard. Discours du récit: essai de méthode. Paris : Éditions du Seuil, 1983.

. Figuras. Trad. Ivonne Montanelli. São Paulo: Perspectiva, 197.

GOTLIB, Nádia Battella. "Quando o objeto cultural é a mulher". In Organon, revista do Instituto de Letras da Universidade Federal do Rio Grande do Sul, v. 16, n. 16, 1989.

. Teoria do conto. São Paulo: Editora Ática, 1985. 
GROULT, Benoîte. Le féminisme au masculin. Paris: Éditions Denoël/Gonthier, 1977.

HEGEL, G. W. Friedrich. Fenomenologia do espírito. Trad. Paulo Meneses. Rio de janeiro: Vozes, 1992.

HÉRITIER, Françoise. Masculin-feminin: la pensée de la différence. Paris: Éditions Odile Jacob, 1996.

HERRY, Mylène. "La femme: représentation, nature et culture" in Mulher Cultura e sociedade na América Latina, Lisboa: Edições Colibri 2003 pp. 143-152.

HUMPHREY, Robert. O fluxo da consciência. Um estudo sobre James Joyce, Virginia Woolf, Dorothy Richardson, William Faukner e outros. Trad. Gert Meyer. Rio de Janeiro: Editora McGRAW-HILL do Brasil, 1976.

JOLLES, André. Formas simples. Trad. De Alvaro Cabral. São Paulo: Cultrix, 1976. JOUVE, Vincent. L'effet-personnage dans le roman. Paris: Presses Univesitaires de France, 1992.

KAYSER, Wolfgang. Análise e interpretação da obra literária. 4. ed. Port. Ver. Por Paulo Quintela. Coimbra: A. Amado, 1967, v. I e II.

KRISTEVA, Julia. Etrangers à nous-mêmes. Paris: Librarie Arthème Fayard, 1988.

LOPES, Oscar. A busca de sentido: questões de literatura portuguesa. Lisboa: Editorial Caminho, 1994.

LOURENÇO, Eduardo. "Situação da literatura portuguesa", in O Canto do Signo Existência e Literatura (1957-1993). Lisboa: Ed. Presença, 1994. 255-267.

MACEDO, Ana Gabriela e AMARAL, Ana Luísa. Dicionário da crítica feminista. Porto: Edições Afrontamento, 2005.

MAGALHÃES, Isabel Allegro. 0 sexo dos textos: Estudos de Literatura Portuguesa. Lisboa: Caminho, 1995.

. O tempo das mulheres. Lisboa: Imprensa Nacional-Casa da Moeda, 1987.

. "Os véus de Ártemis: alguns traços da ficção narrativa de autoria feminina". In

Colóquio Letras, n. 125/126, julho-dezembro de 1992.

MAGALHÃES, Júnior, R. A arte do conto; sua história, seus gêneros, sua técnica, seus mestres. Rio de Janeiro: Bloch, 1972. 
MALUF, Marina e MOTT, Maria Lúcia. "Recônditos do mundo feminino". In História da vida privada no Brasil, vol. III. Org. Fernando Novais. São Paulo: Companhia das Letras, 1999.

MARÍAS, Julián. A mulher no século XX. Trad. Diva Ribeiro de Toledo Piza, São Paulo: Editora Convívio, 1981.

MENDONÇA. Fernando. "Fiç̧ão de autoria feminina ou o sabor da solidão". In A literatura portuguesa no séc. XX. São Paulo: Hucitec, 1973, p. 172-194.

MURARO, Rose Marie e PUPPIN, Andréa Brandão. Mulher, Gênero e Sociedade. Rio de Janeiro: Relume dumará, 2001.

NADER Maria Beatriz. Mulher: do destino biológico ao destino social. Vitória Editora da Universidade Federal do Espírito Santo - EDUFES, 1997.

NÓBREGA, Isabel da. Viver com os outros. Lisboa: Prelo Editora, 1972.

NUNES, Benedito. O tempo na narrativa. São Paulo: Editora Ática, 1995.

PAIVA, Vera. Evas, Marias, Liliths...As voltas do feminino. São Paulo: editora Brasiliense, 1993.

PASSOS, Cleusa Rios P. Guimarães Rosa: do feminino e suas histórias. São Paulo: Hucitec/FAPESP, 200.

PERAULT, Charles. La belle au bois dormant. Paris: Gallimard, 1931.

PERRIOT, Françoise. Agir pour la cause des femmes. Paris: Éditions Le Pré aux Clercs, 2005.

PERROT, Michelle. Une histoire de femmes est-elle possible. Paris: Éditions Rivages, 1984.

PIÑON, Nelida. Tempo das frutas. Prefácio: Maria Alice Barroso, Rio de Janeiro: José Alvaro Editor, 1966.

. Sala de armas. 2. ed. Rio de Janeiro: Nova Fronteira, 1981.

PIRES, José Cardoso. Cartilha do Marialva. Lisboa: Moraes Editores, 1970.

RÉGIO, José. Histórias de mulheres. Porto: Brasília Editora, 1986.

RESCH, Yannick. Corps féminin, corps textuel: essai sur le personnage féminin dans l'oeuvre de Collete. Paris: Librairie C. Klincksieeck, 1973.

ROCHA-COUTINHO, Maria Lucia. Tecendo por trás dos panos: a mulher brasileira nas relações familiares. Rio de Janeiro: Rocco, 1994. 
ROCHA, Clara. Máscaras de Narciso: Estudos sobre literatura autobiográfica em Portugal. Coimbra, 1992.

RODRIGUES, Urbano Tavares. "Imagens da Mulher na Literatura Portuguesa do séc. XX”. In Ensaios de Escreviver. Porto: Inova, pp. 187-222, 1970.

ROSENFELD, Anatol. "Reflexões sobre o romance moderno". In Texto e contexto I. São Paulo: Editora Perspectiva, 1996.

SAFFIOTI, Heleieth lara Bongiovani. A mulher na sociedade de classes: mito e realidade. São Paulo: Quatro Artes, 1969.

SAND, George. Oeuvres autobiographiques vol. I. Paris: Gallimard, 1970.

SANTOS, Boaventura de Souza. Pela mão de Alice: o social e o político na pósmodernidade. São Paulo: Cortez, 2006.

SAINT-POINT, Valentine. Manifeste de la femme futuriste. Paris, Éditions Mille et une nuits, 2005.

SARAIVA, José Hermano. História concisa de Portugal. Portugal: Europa-América, 1996.

SOUZA, Neusa Santos. "O estrangeiro: nossa condição". In 0 estrangeiro. Org. Caterina Koltai, São Paulo: Escrita, 1998.

SULLEROT, Évelyne. Historia y sociología del trabajo femenino. Barcelona: Ediciones Península, 1988.

LÉVI-STRAUSS, Claude. "Regarder Écouter lire". In Oeuvres. Paris: Éditions Gallimard, 2008.

SÜSSEKIND, Flora. Literatura e vida literária: polêmicas, diários \& retratos. 2. ed. Belo Horizonte: Editora UFMG, 2004.

TACCA, Oscar. As vozes do romance. Coimbra: Livraria Almedina, 1983.

TELLES, Lygia Fagundes. Meus contos esquecidos, antologia. Rio de Janeiro: Rocco, 2005.

TRAQUINA, Nelson. O jornalismo português em análises de casos. Lisboa: Caminho, 2001.

TORRES, Alexandre Pinheiro. "Sobre Os Idólatras de Maria Judite de Carvalho". In Diário de Lisboa, Lisboa: 10 de setembro de 1970.

WOOLF, Virginia. Orlando. Trad. Cecília Meireles. São Paulo: Abril Cultural, 1972. 
_ . "Métiers de femmes". In Essais, Paris: Éditions Seghers, 1976.

. Um teto todo seu. Trad. Vera Ribeiro. Rio de Janeiro: Nova Fronteira, 1985.

YAGUELO, Marina. "A la recherche d'une identité culturelle". In Les mots et les femmes. Paris: Éditions Payot, 1992.

ZEPHIR, Jacques J. Le neo-féminisme de Simone de Beauvoir : trente ans après

Le deuxième sexe : un post-scriptum. Paris : Danoël/Gnthier, 1982. 


\section{Anexo: entrevista com Urbano Tavares Rodrigues}

Como parte anexa à tese encaminhamos na íntegra a entrevista realizada em 22 de outubro de 2008, com o escritor e marido de Maria Judite de Carvalho, Urbano Rodrigues Tavares.

A entrevista foi feita em um fim de tarde na casa do escritor que gentilmente nos recebeu em sua morada calma e repleta de livros e lembranças, em um prédio antigo não muito longe do centro de Lisboa. $O$ apartamento situa-se no segundo andar no alto de um pequeno café, lá encontramos o escritor que, com 85 anos, mantém os olhos plenos de esperança. Urbano Tavares nos recebeu em sua biblioteca, entre livros e discos foi aos poucos relatando com emoção algumas histórias sobre o casal.

A entrevista nos possibilitou entender melhor o olhar da autora sobre a sociedade lisboeta de sua época, e reforçar um aspecto já percebido na leitura das crônicas da autora: sua posição questionadora e observadora em relação á conduta feminina e o papel social da mulher.

Senhor Urbano, havia algum tipo de engajamento político de Maria Judite, sobretudo nos anos de 1960 em decorrência das perseguições políticos que sofreram?

UT: Não diretamente, mas ela era muito simpatizante do Partido Comunista (PC), votava nos candidatos do partido, mas temia quando eu escondia os amigos em casa. Isso porque presenciou por duas vezes a polícia indo me buscar em nossa casa, de arma em punho. A segunda vez, foi em 1968, passei cinco meses na prisão e fui muito torturado, eles até a impediram de me ver certa ocasião, pois ainda estavam muito visíveis à marcas da tortura. Mas ela sempre ia me visitar com muita dignidade e resignação, ainda que sofresse muito com tudo isso. Maria Judite também era alguém que se sensibilizava muito diante da opressão causada pelo salazarismo, o regime a incomodou imenso.

Como o senhor descreveria o olhar social de Maria Judite, e suas inquietudes em relação ao meio em que vivia? 
UT: Ela tinha uns olhos de muita ironia quando observava ou descrevia a sociedade, via detalhes que a deixavam chocada, mas ao mesmo tempo tinha uma ternura bonita pela vida e os acontecimentos que aproximavam as pessoas. No entanto era cética e pessimista sobre alguns aspectos, como as modernizações que excluíam muitos e transformavam alguns, porém ela conseguia ter bom humor quando estava entre as pessoas queridas. Ela andava pelos autocarros sempre a observar como quem pesquisa a vida humana, ou está a testar o êxito das relações entre as pessoas.

\section{E o que representava para autora a vida em sociedade?}

UT: penso que era muito importante, mas ela era um pouco reservada, fechava-se por vezes e não queria muito movimento por perto, sua recusa a muita publicidade acabou por prejudicar um pouco a divulgação de sua obra.

\section{Qual era a posição de MJC sobre o papel social da mulher em Lisboa?}

UT: Ela era muito observadora, portanto via em detalhes a situação feminina ao seu redor, a falta de direitos e a submissão a que era obrigada a mulher a incomodava muito, a ausência da mulher como cidadã e interventora da sociedade também a chocava. No entanto ela logo sentiu que começava a acontecer um movimento de liberação da mulher no final da década de 1950, então isso a deixava um pouco mais voltada para a observação dessas mudanças. Escritores como José Cardoso Pires, Augusto Abelaire e eu, começamos a observar que a condição da mulher estava a tomar ares de mudança e que isso logo explodiria, como foi o que posteriormente aconteceu nos anos posteriores.

\section{O que representou para a escritora os anos que vocês moraram na França?}

UT: Foram anos muito importantes, de grande valor intelectual, conhecemos vários escritores (Sartre, Camus, Beauvoir, etc.). Estreitamos laços com Camus, canhecemos idéias, e tudo que havia de novo na literatura em França, isso foi de muita valia para a obra de Maria Judite. Lembro-me de uma noite, creio que em 1953, que visitamos um cassino em Paris, era um dia de sorte e rápido ganhei muito dinheiro, queria continuar, mas a Maria Judite sentiu medo que eu perdesse tudo e me 
fez parar, para assim garantir o que já tinha ganhado, era bastante dinheiro, então eu Ihe comprei um casaco de pele, pois os dias estavam frios, e fizemos uma viagem para Genebra; foram momentos bem felizes.

Existem crônicas de Maria Judite em que ela cita e discute idéias feministas ou sobre o feminino, algumas são muito próximas das expostas por Simone de Beauvoir em Le deuxième sexe, há algum momento em que MJC leu a autora francesa?

UT: Maria Judite lia frequentemente de Simone de Beauvoir, lembro-me bem de a ter visto ler Le deuxième sexe no período em que estávamos em França, um pouco antes de eu ter conhecido a autora pessoalmente. O livro a inquietou e a deixou reflexiva por vários dias. As idéias da autora francesa chamavam-lhe muito a atenção, ela as julgava revolucionárias e muito fiéis ao que dizia respeito ao papel social que muitas vezes a mulher executava sem questionar. Posteriormente ela passou a ler tudo que a autora publicava e gostava muito também dos romances.

\section{O senhor lembra em que ano ela leu Le deuxième sexe?}

UT: Não me lembro muito bem, mas creio que foi no início dos anos 50 , acho que 1953.

Essa leitura pode ter influenciado em sua escrita, pois seu primeiro livro só foi publicado em 1959...

UT: Sim, mas a Maria Judite já vinha escrevendo muito tempo antes de publicar, eu a incentivei muito a começar a escrever, mesmo antes de partirmos para a França, eu sabia que o que ela escrevia era muito bom. O primeiro livro publicado, Tanta gente, Mariana, eu me lembro que ela me deu o manuscrito para que eu lesse durante uma viagem que fiz a Paris, quando comecei a lê-lo no trem, chorei e me emocionei muito. Ao chegar disse a ela que era muito bonito o que ela havia escrito e que deveria publicar, ela aceitou e o livro foi bem recebido pela crítica. Não sei se houve diretamente uma influência, mas é certo que ela era muito sensível às denúncias feitas pela literatura de Simone de Beauvoir. 
Alguma vez a autora se posicionou em relação aos movimentos feministas surgidos nos anos de $1960 ?$

UT: Ela sempre ficou observando de longe, nunca militou ou se engajou a nenhum deles, mas simpatizava muito com as lutas desses movimentos. Era muito amiga de Maria Tereza Horta e apoiava suas lutas sempre. Mas penso também que o problema do feminino sempre esteve entre suas preocupações, principalmente no que diz respeito à opressão, pois ela foi criada com duas tias já idosas e muito conservadoras, isso também foi uma das causas para que se tornasse uma mulher mais reservada. $A$ condição limitada e o papel da mulher na família e na sociedade foram aspectos para os quais ela sempre esteve muito sensível.

A escrita de Maria Judite contém uma certa angústia e falta de esperança, aos poucos vão sendo banidas todas as possibilidades de se compensar a tristeza e os malogros da vida, podemos ligar essa característica da obra à pessoa?

UT: Creio que um pouco sim, pois ela não via o futuro com muitas esperanças, não acreditava em grandes mudanças políticas e nem sociais, ela jamais acreditou que chegaria o 25 de abril, eu sim, sempre achei que esse dia chegaria; para ela isso foi uma grande surpresa. Quando estávamos sobre o efeito desse acontecimento ela olhava a cidade abismada e dizia que eram poucas as vezes que a vida tinha lhe surpreendido com tamanha intensidade.

\section{Como o senhor definiria o ato de escrever para Maria Judite de Carvalho?}

UT: Era uma maneira de falar, de protestar, de dizer tudo que a afligia em relação ao mundo e à sociedade em que vivia...sua sensibilidade era uma lâmina que cortava os acontecimentos de ponta a ponta extraindo aquilo que havia de mais profundo, ás vezes com melancolia e tristeza, outras com precisão, ironia e crítica. Penso que a escrita era sua maneira de se comunicar consigo e com os outros, por isso era de grande importância para ela...Mas a pintura também ocupava um imenso lugar em sua vida, sendo muitas vezes mais forte do que a escrita. 
